Исследование динамики выхода летучих веществ из угольной пыли методами термогравиметрического анализа

$$
\text { стр.23 }
$$

Выпуск 4-2019 | Кемерово | ISSN 2072-6554 | DOI 10.26631/issn.2072-6554
Влияние развития угледобычи на экологическую обстановку в Кузбассе

\title{
BECTHИK
}

Научного центра по безопасности работ в угольной промышленности

\section{ИННОВАЦИИ И}

\section{RRHA}

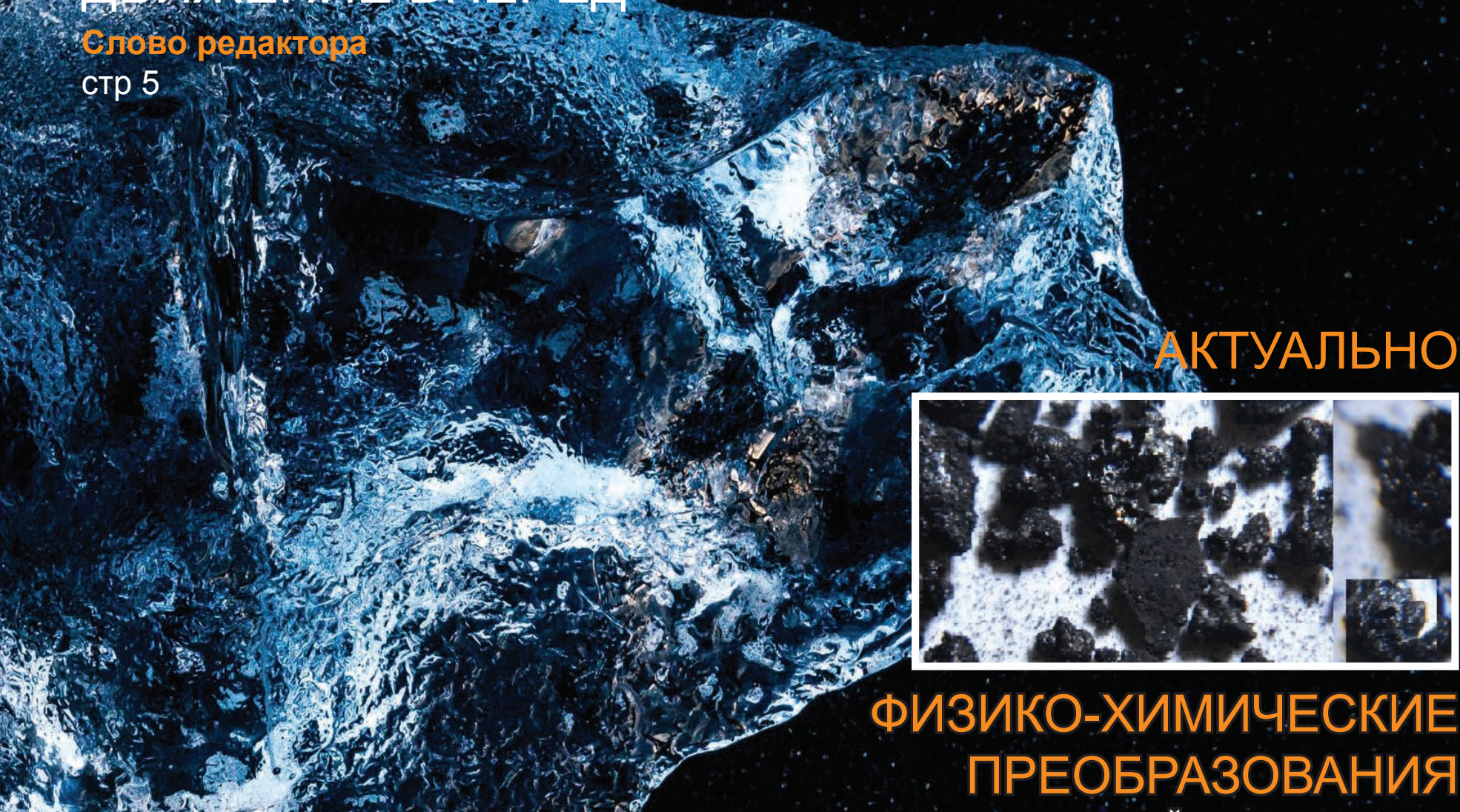




\title{
B
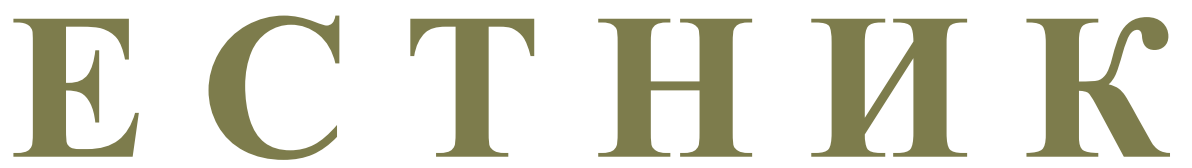 \\ Научного центра по безопасности работ в угольной промышленности
}

\author{
Научно-технический журнал
}

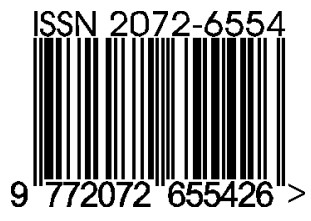

Кемерово 
ВЕСТНИК

\section{Научного центра}

по безопасности работ

в угольной промышленности ISSN 2072-6554

№ 4-2019
Выходит 4 раза в год

Подписной индекс

в Каталоге Агентства

«Роспечать» 2018 г. - 35939

\section{ЖУРНАЛ ЗАРЕГИСТРИРОВАН}

Федеральной службой по надзору в сфере связи, инфоормационных технологий и массовых коммуникаций.

Свидетельство о регистрации средства массовой информации ПИ № ФС77-71529 от 13.11.2017 г.

\section{ЖУРНАЛ ВКЛЮЧЕН}

в «Перечень российских рецензируемых научных журналов, в которых должны быть опубликованы основные научные результаты диссертаций на соискание ученых степеней доктора и кандидата наук», сформированный ВАК при Минобрнауки России

\section{Учредитель и издатель}

научно-технического журнала «Вестник...»: Общество с ограниченной

ответственностью «ВостЭКО»

(ООО «ВостЭКО»)

Адрес учредителя и издателя:

650002, Россия, Кемеровская область, г. Кемерово,

Сосновый бульвар, дом 1, кабинет 415

Адрес редакции:

650002, Россия, Кемеровская область, г. Кемерово, Сосновый бульвар, дом 1

Редакторы: М. В. Ярош, Л. С. Кузавкова, Д. А. Трубицына

Компьютерная верстка Д. А. Трубицына

тел. 77-86-62, 64-26-51.

e-mail: yarosh_mv@mail.ru dtrubitsyna@gmail.com

www.ind-saf.ru

Позиция редакции не всегда совпадает с точкой зрения авторов публикуемых материалов

В номере использованы материалы сайтов www.lori.ru, www.freelmages.com, www.unsplash.com и www.graphicriver.net

\section{$16+$}

\section{(๖) 000 «ВостЭКО», 2019}

Главный редактор: Н. В. Трубицына

\section{Редакционная коллегия:}

Н. В. Трубицына - главный редактор, заместитель директора по научной работе ООО «ВостЭКО», д-р техн. наук

А. С. Ярош - заместитель главного редактора, канд. техн. наук

Д. В. Исламов - депутат ГД ФС РФ, кандт. техн. наук

А. А. Трубицын - консультант по научной работе ООО «Горный-ЦОТ», НАО «НЦ ПБ», д-р техн. наук, проф.

А. А. Васильев - заведующий лабораторией ФГБУН «Институт гидродинамики им. М.А. Лаврентьева СО РАН», д-р физ.-мат. наук, профр.

А. М. Брюханов - директор МакНИИ, д-р техн. наук

В. И. Клишин - директор Института угля Федерального исследовательского центра угля и углехимии СО РАН, чл.-корр. РАН, д-р техн. наук, проф.

3. Р. Исмагилов - директор Института углехимии и химического материаловедения Федерального исследовательского центра угля и углехимии СО РАН, чл.-корр. РАН, д-р хим. наук, проф.

А. В. Шадрин - ведущий научный сотрудник Института угля ФИЦ УУХ СО РАН, д-р техн. наук

В. Г. Казанцев - заведующий кафедрой «БТИ» (филиал) ФГБОУ ВПО «АлтГТУ им. И.И. Ползунова», д-р техн. наук

В. С. Зыков - заместитель генерального директора АО «НЦ ВостНИИ», д-р техн. наук, профр.

Д. А. Трубицына - выпускающий редактор ООО «ВостЭКО»

М. В. Ярош - редактор ООО «ВостЭКО» 


\section{INDUSTRIAL SAFETY}

Scientific-technical magazine 


\section{INDUSTRIAL SAFETY ISSN 2072-6554}

№ 4-2019
Is issued 4 times a year

Subscription index

in «Rospechat» Agency

Catalogue: Year 2018 - 35939

\section{MAGAZINE IS REGISTERED}

by the Federal Service for Supervision in the Sphere of Communications, Information Technologies and Mass Communications. Registration cerificate of mass information means PI № FS77-71529 dated by $13.11 .2017 \mathrm{r}$.

\section{THE MAGAZINE IS INCLUDED}

into "The list of russian reviewed scientific magazines in which main scientific results of dissertations for scientific degrees of a doctor and a candidate of sciences must be published». The list is formed by Higher Attestation Commossion of RF Ministry of Education and Science.

\section{Promoter and publisher of "Industrial Safety» scientific-technical magazine: Co Ltd "VostEKO»}

Address of the promoter and publisher:

650002 , Russia, Kemerovskaja oblast, Kemerovo, Sosnovyi bd., 1 , office 415

Address of the editors: 650002, Russia, Kemerovskaja oblast, Kemerovo, Sosnovyi bd., 1

Editors: M.V. Yarosh, L.S. Kuzavkova, D.A. Trubitsyna Computer layout D.A. Trubitsyna

Tel. 77-86-62, 64-26-51.

e-mail: yarosh_mv@mail.ru dtrubitsyna@gmail.com

www.ind-saf.ru www.indsafe.ru

The edition position not always coincides with the point of view of authors of published materials

In the issue of the magazine materials of sites www.lori.ru, www.freelmages.com, www.unsplash.com and www.graphicriver.net are used

\section{$16+$}

(c) Co Ltd «VostEKO», 2019

Address of the painting

650065, Russia, Kemerovskaja oblast, Kemerovo, prosp.

Oktyabrsky, 28 of. 215

tel. 8 (3842) 657889.

$\mathrm{OOO}$ «INT».

\section{Chief editor: N. V. Trubistyna}

\section{Editorial board:}

N. V. Trubitsyna - chief editor, deputy director for scientific work of OOO «VostEKO», doctor of technical sciences

A. S. Yarosh - deputy chief editor, candidate of technical sciences

D. V. Islamov - deputy of the State Duma of the Federal Assembly of the Russian Federation, candidate of technical sciences

A. A. Trubitsyn - scientific work consultant, $\mathrm{OOO}$ "Gorny COT", NAO "NC PB", doctor of technical sciences, professor

A. A. Vasil'ev - Head of the Laboratory FGBUN "M.A. Lavrentyev Institute of Hydrodynamics SB of RAS, doctor of physical and mathematical sciences, professor

A. M. Brjuhanov - Director of MakNII, doctor of technical sciences

V. I. Klishin - director of the Institute of coal, Federal research center of coal and coal chemistry SB RAS, corresponding member of RAS, doctor of technical sciences, professor

Z. R. Ismagilov - director of the Institute of coal chemistry and materials chemistry, Federal research center of coal and coal chemistry SB RAS, corresponding member of RAS, doctor of chemical sciences, professor

A. V. Shadrin - Leading researcher of the Institute of Coal FIC UUH SB RAS, doctor of technical sciences

V. G. Kazantsev - chairman of «BTI» (branch) FGBOU VPO «AltGTU after I.I.Polzunov», doctor of technical sciences

V. S. Zykov - deputy general director JSC «ScC VostNII», doctor of technical sciences, professor

D. A. Trubitsyna - OOO «VostEKO» Commissioning Editor

M. V. Yarosh - OOO «VostEKO» editor 


\section{Дорогие читатели, коллеги и друзъя!}

Друзья, четвёртый номер журнала вышел из печати, как всегда, в канун Нового года. Публикации в нём отражают часть результатов и конкретных достижений коллективов, чья деятельность связана с решением проблем промышленной безопасности на предприятиях угледобывающей отрасли и экологии в регионе. Это два стратегически важных для нас направления деятельности. И на это был направлен интеллектуальный и технологический потенциал всех заинтересованных государственных, научных и коммерческих структур в 2019 году.

В уходящем году мы отметили 300-летие Ростехнадзора. И знаменательно, что в юбилейный год Кузбасс посетил с рабочим визитом глава ведомства Алексей Алёшин. Здесь он и губернатор Сергей Цивилёв подписали соглашение о сотрудничестве. Тема безопасности труда на предприятиях ведущего угледобывающего бассейна страны стала основной во время их встречи. Руководитель главного надзорного органа России подчёркивал тогда, что в Кузбассе проделана колоссальная работа, направленная на создание надежной системы обеспечения безопасности на объектах горнодобывающей инфраструктуры. И это обусловило предотвращение техногенных катастроф, сохранение жизни и здоровья людей, а также усилило внимание к вопросам охраны окружающей cредbl.

Этот круг проблем профессионального сообщества является для нашего издания магистральным. Подтверждение тому - любой из номеров. Редакционная коллегия журнала отслеживает тенденции профильной тематической ниши и формирует каждый номер "Вестника" и его редакционный портфель с учётом современных трендов, а также ожиданий и потребностей угледобывающих предприятий. В этом номере редакичонный коллектив предлагает вам интересную подборку статей по борьбе с пылью. В них поднимаются вопросы методологии определения участия пыли во взрыве, а также экологические аспекты пылевой безопасности и технологии борьбы с пылью на поверхностных комплексах. Но это только часть той тематики, которая для всех нас особо важна. В номере достаточно много публикаций на другие интересные для читателей темы.

Не устану подчёркивать, что информационное поле всегда актуализируется при непосредственном участии наших авторов и авторских коллективов. Коллеги, мы очень дорожим сотрудничеством с вами и готовы его расширять и углублять в 2020 году. Пусть он станет для вас плодотворныл, а ваши изыскания, результаты исследований и разработанные проекты получат заслуженное внимание, будут конкурентоспособны $и$ востребованы потребителями на рынке.

В 2019 году произошла актуализация всех профильных направлений нашей деятельности как на федеральном, так и региональном уровнях. Они действуют совместно и эффективно. И свидетельство тому - прошедшее в декабре в Москве заседание Совета Российской Академии наук по приоритетному направлению Стратегии научно-технического развития страны, на котором губернатор Кузбасса Сергей Цивилёв представил ученым комплексную научно-техническую программу полного инновационного ичила «Разработка и внедрение комплекса технологий в областях разведки и добычи твердых полезных ископаемых, обеспечения промышленной безопасности, биоремедиации, создания новых продуктов глубокой переработки из угольного сырья при последовательном снижении экологической нагрузки на окружающую среду и рисков для жизни населения». По сути руководством региона поставлена государственная задача - решить комплекс проблем экономического, технологического и сочиильного характера, которые накопились в Кузбассе за многие годы. Ключевая роль в этом принадлежит учёным, производственным коллективам и предпринимательскому сообществу.

Наш научно-технический журнал "Вестник" - отражает весь спектр их деятельности и совместных усилий. В 2020 году редакционный коллектив издания продолжит освещать инновационные решения поставленных задач и представлять читателям перспективные и флагманские научные и технологические проекты лидеров отрасли. Амби циозные, но вполне реалистичные задачи, стали стартовой базой и импульсом для ускоренного развития топливно-энергетического комплекса Кузбасса и России. И новый, 2020 год своё слово скажет! Пусть он войдёт в наши трудовые коллективы и в наши семьи с миром, счастьем и верой в общий успех!

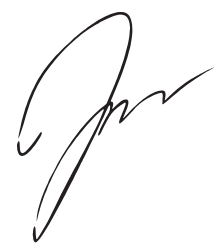

НЭЛЯ ТРУБИЦЫНА,

главный редактор, д.т.н. 


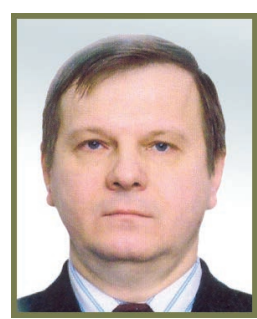

C.Б. Романченко //

S. B. Romanchenko romanchenkosb@mail.ru

д-р техн. наук, доцент, ведущий научный сотрудник ФГБУ ВНИИПО МЧС России, Россия, 143903, Московская область, г. Балашиха, мкр. ВНИИПО, д. 12 doctor of technical sciences, assistant professor, leading researcher of FGBU VNIIPO MChS of Russia, microdistrict 12, VNIIPO, Balashikha, Moscow Region, 143903, Russia

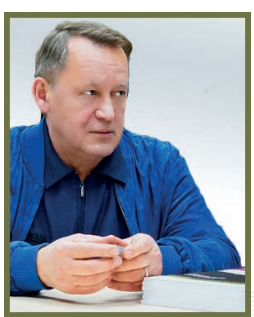

А. А. Трубицын //

A.A. Trubitsyn atrubitsyn@rambler.ru

д-р техн. наук,, профессор, консультант по научной работе НАО "НЦ ПБ", "Горный ЦОТ", Россия, 650002, г. Кемерово, Сосновый бульвар, 1

doctor of technical sciences, professor, Scientific Advisor, NAO "Scientific Center of Industrial Safety", 1, Sosnoviy bulvar, Kemerovo, 6500002, Russia

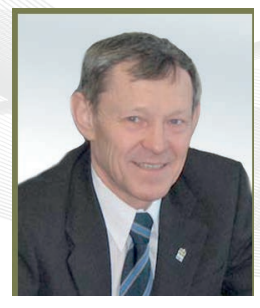

В.В. Соболев // V.V.Sobolev sobolev567@gmail.com

доктор техн. наук, заместитель генерального директора $\mathrm{AO}$ «НЦ ВостНИИ», Россия, 650002, г. Кемерово, ул. Институтская, 3 Doctor of technical sciences, deputy general director of JSC «ScC VostNII» 3, Institutskaia St., Kemerovo, 650002, Russia

\section{ФИЗИКО-ХИМИЧЕСКИЕ ПРЕОБРАЗОВАНИЯ В УГОЛЫНОЙ ПЫЛИ ПРИ ВЗРЫВАХ PHYSICAL AND CHEMICAL TRANSFORMATIONS IN COAL DUST BY EXPLOSIONS}

В статье рассмотрены свойства угля, определяющие опасность взрыва угольно-пылевых аэрозолей. Отмечено отличие показателей вызрывчатости летучих газов из угольной пыли от метана и его гомологов. На примере проб, отобранных на реальной аварии, исследованы фризические и химические изменения в угольных частицах при взрывах. На реальном материале исследовано изменение величины остаточного выхода летучих веществ из отложившейся угольной пыли по длине аварийной выработки, а также в местах сопряжений группы выработок и после поворота ударной взрывной волны (УВВ) под углом 90 градусов. Впервые получены результаты по изменению интенсивности взрывного горения в разветвленной сети горных выработок при прохождении УВВ мест сопряжения, пересечения и поворота выработок, проветриваемых системой шахтной вентиляции. Исследовано влияние добавок сланцевой пыли на величину и динамику выхода летучих веществ. Обоснована необходимость исследований в области выхода летучих веществ на новой лабораторной базе.

The article considers the properties of coal, which determine the explosion danger of coal-dust aerosols. A difference in the explosiveness index of coal dust volatile gases from methane and its homologues is noted. On the example of samples taken in a real accident, the physical and chemical changes in coal particles during explosions are investigated. On real material, the change in the volume of the residual emission of volatile substances from the deposited coal dust along the accident affected working, as well as at the junction spots of a group of mine workings and after the explosion shock wave (ESW) turn at an angle of 90 degrees, was studied. For the first time, results have been obtained on the change in the intensity of explosive combustion in an extensive network of mine workings during the ESW passage of junction, intersection and mine working turning spots ventilated by a mine ventilation system. The effect of shale dust additives on the volume and dynamics of volatile substances' emission is investigated. The necessity of research in the field of volatile substances' emission at a new laboratory base is substantiated.

КлючевЫе слова: ВЗРЫВ, ПАРАМЕТРЫ ВЗРЫВА, УГОЛЬНЫЙ АЭРОЗОЛЬ, ДИСПЕРСНЫЙ СОСТАВ, НИЖНИЙ КОНЦЕНТРАЦИОННЫЙ ПРЕДЕЛ ВЗРЫВАЕМОСТИ, ДАВЛЕНИЕ ВЗРЫВА, СКОРОСТЬ ПЛАМЕНИ, ТЕРМИЧЕСКИЙ АНАЛИЗ, ТЕРМОДЕСТРУКЦИЯ УГЛЯ, ТЕРМОГРАВИМЕТРИЯ, ВЫХОД ЛЕТУ- 
Key words: EXPLOSION, EXPLOSION PARAMETERS, COAL AEROSOL, DISPERSE COMPOSITION, LOWER EXPLOSIVE CONCENTRATION LIMIT, EXPLOSION PRESSURE, FLAME SPEED, THERMAL ANALYSIS, THERMAL DECOMPOSITION OF COAL, THERMOGRAVIMETRY, VOLATILES EMISSION, SHALE DUST, DUST EXPLOSION PROTECTION

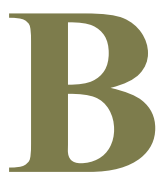

\section{ВЕДЕНИЕ}

Взрывы с участием угольной пыли традиционно являются одним из наиболее тяжелых видов аварий в мировом горном деле. При этом наличие длительных периодов, когда в шахтах той или иной угледобывающей страны отсутствуют взрывы пылеметановых смесей, не является гарантией безопасной работы шахт в будущем:

- на шахтах РФ в XXI веке крупные взрывы происходили со средним интервалом около 3-х лет (2004 г.; 2007 г.; 2010 г.; 2013 г.; 2016 г.). Из крупных ЧС последнего периода необходимо отметить аварии на шахтах «Воркутинская» 01.02.2013г. и «Шахта Северная» 25.02.2016 г., являющихся структурными подразделениями (СП) АО «Воркутауголь»;

- в США после 40-летнего периода отсутствия крупных аварий (1970-2010гг) произошел взрыв на шахте Upper Big Branch (компания Massey Energy, штат Западная Вирджиния) с гибелью 29 шахтеров [1]. Данный взрыв с участием угольной пыли был наиболее тяжелой аварией в Соединенных Штатах с 1970 года, когда 38 шахтеров погибли в объединенной системе шахт № 15 и 16 компании Finley Coal в Хайдене, штат Кентукки;

- в Польше относительно безопасный по взрывам 15-летний период (с 1988 г по 2003 год) завершился взрывом пыли на практически нега-

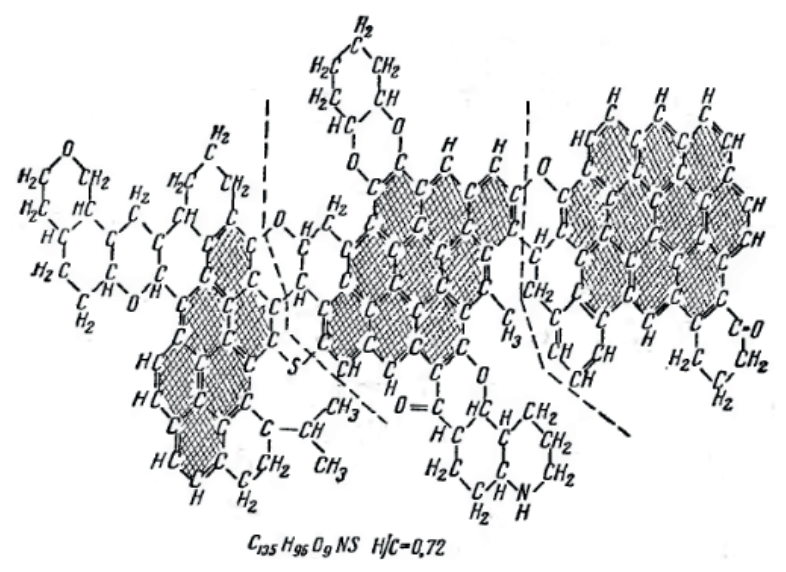

Рисунок 1 - Модель макромолекулы угольного вещества (заштрихована ароматическая часть структуры в молекуле) $[4,5]$

Figure 1 - Model of a coal substance macromolecule (shaded - aromatic part of the structure in the molecule) $[4,5]$ зовой шахте Ясь-Мос [2,3], где инициалом для воспламенения пылевого аэрозоля послужили взрывные работы с нарушением ПБ.

Наличие крупных аварий в шахтах указывает на техническую сложность полного устранения взрывов угольной пыли, а периоды работ «без катастроф» могут приводить к определенной утрате навыков борьбы с пылевзрывоопасностью или снижению уровня подготовки персонала, как на этапах предотвращения взрывов, так и на стадиях ликвидации и расследования аварий.

\section{1.СВОЙСТВА УГЛЯ, ОПРЕДЕЛЯЮЩИЕ ВЗРЫВООПАСНОСТЬ УГОЛЬНОЙ ПЫЛИ}

В работах по фризико-химическим свойствам углей $[4,5]$ угольное вещество представляется как высокомолекулярное соединение, в котором макромолекула - это конденсированная ароматическая система, состоящая из ядра, окруженного химически связанными молекулами. В состав молекул углей входят сотни либо тысячи атомов с многократным повторением основной их структурной группировки. Структура макромолекул угля представляется как ароматическая решетка с атомами углерода в вершинах, окруженная молекулами боковых групп (рисунок 1).

Ядро макромолекулы угля, имеющее в своем составе бензольное кольцо, обладает наибольшей термоустойчивостью, а окружающее ядро боковые группы - углеводороды со сравнительно небольшой термической устойчивостью. При термическом воздействии на угольное вещество боковые группы в первую очередь выделяются из угля в виде летучих веществ.

Порядок определения численных характеристик выхода летучих веществ, а также показателей пожаровзрывоопасности веществ регламентирован рядом нормативных документов [6-9]. В ранее проведенных исследованиях принято, что из высокомолекулярного соединения угля - при нагревании до $1173^{\circ} \mathrm{K}\left(900^{\circ} \mathrm{C}\right)$ происходит термодеструкция вещества с выделением относительно «простых» по химическому составу газов $[2,3,10]$ : водород 18,39\%; оксид углерода 73,4\%; диоксид углерода 2,8\%; метан 4,38\%; этан 0,32\%; пропан 0,08\%; пропилен и изобутан 


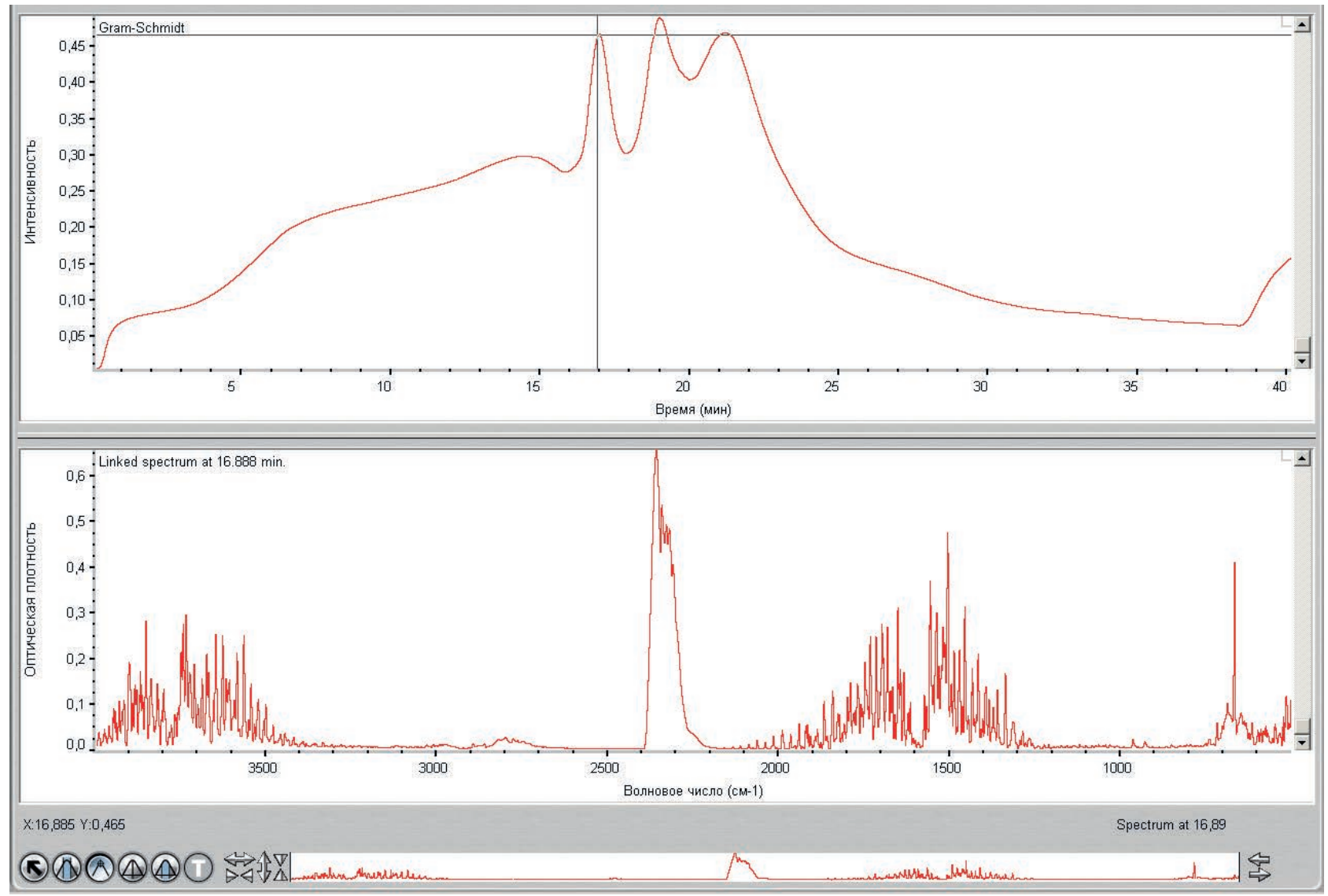

Рисунок 2 - Результаты инфрракрасной спектрометрии газов, выделенных в процессе термодеструкции угольной пыли (в совмещении с ТГ кривой - верхний фррагмент)

Figure 2 - The results of infrared spectrometry of gases emitted during thermal decomposition of coal dust (in combination with the TG curve - the upper fragment)

суммарно $0,33 \%$; сероводород $0,3 \%$. Исследования МакНИИ [11] указывали на наличие смолистых веществ (сложные углеводороды) водорода, этана, непредельных углеводородов (этилен, ацетилен и др.), сероводорода и метана. Вместе с этим на современной научной базе выход «простых» газов при термодеструкции угля явно не определяется [12], рисунок 2.

По известному принципу «Natura non facit saltus» ("Природа не делает резких скачков" лат.) из сложного высокомолекулярного соединения - угля - (рисунок 1) логичным является выход сложных органических соединений, составляющих основу летучих веществ (рисунок 2). Состав газов, выделяющихся из угольного вещества при нагреве, рассмотрен авторами настоящей статьи в работе [12]. Основные выводы по вопросу состава газов, выделяющихся из угля, сводится к следующему:

- из угля выделяются газы, сложные по химическому составу и имеющие отличные от $\mathrm{CH}_{4}$ показатели пожаро-взрывоопасности;

- даже из одного образца угля состав газов существенно отличается исходя из атмосфреры нагрева, режима и температуры нагрева, наличия влаги и от дисперсного состава пыли;

- совмещенными ТГА-АГГ ${ }^{2}$ экспериментами подтвержден фракт того, что основной объем выходящих из угольных частиц газов является горючим (95-97\% - при нормативном значении максимального значения размеров частиц и соответственным дисперсным составом пыли $[6,7]$.

Для углеводородных газообразных веществ различной сложности, выделяющихся из угля, основными показателями взрывчатых свойств являются температура воспламенения $T_{\sigma^{\prime}}$, максимальная температура пламени $T_{f \max }$, максимальное давление взрыва, нижний и верхний концентрационные пределы переноса пламени (НКПР/ ВКПР) $[7,8,9]$. Как отмечено выше из нагретых угольных частиц при различном характере протекания процессов пиролиза могут выделяться различные газы. Максимальные и средние температуры их горения по отношению к $\mathrm{CH}_{4}$ (или гомологов метана - $\mathrm{C}_{n} \mathrm{H}_{2 n+2}$ ) могут существенно возрасти, а НКПР - существенно 
снизиться. Если температура горения метана (средняя-максимальная) находится в диапазоне 1250 - $1950^{\circ} \mathrm{C}$, то максимальные температуры горения $T_{f_{\text {мах }}}$ для большинства рудничных газов составляют $2000-2200^{\circ} \mathrm{C}$, a, например, ацетилен имеет широкий концентрационный диапазон взрываемости (таблица 1), низкий НКПР и самую высокую температуру горения: температура «ядра» пламени для $\mathrm{C}_{2} \mathrm{H}_{2}$ составляет $2621^{\circ} \mathrm{C}$ при максимальных её значениях в ореоле до $3150{ }^{\circ} \mathrm{C}$.

Это определяет сложный процесс воспламенения и переноса фронта пламени пылевым аэрозолем и должно учитываться при построении модели взрыва угольной пыли.

С учетом указанных фракторов делаются следующие предположения для построения модели или определения факта участия пыли во взрывах:

- «взрыв частиц угольной пыли» фрактически является взрывом газовой оболочки, формирующейся вокруг частиц при термодеструкции угля в процессе выхода летучих;

- взрыв угольной пыли не возникает при технологическом процессе с любым достижимым пылеобразованием, максимально-возможные концентрации пыли при работе оборудования на 1-2 порядка ниже НКПР;

- за 200-летний период статистических наблюдений за авариями выявлены всего два вида инициирования взрыва угольной пыли: первичный взрыв/вспышка шахтного метана или ведение взрывных работ с нарушениями правил безопасности;

- выход летучих газов в достаточных для воспламенения объемах происходит только в пылевом аэрозоле, отложившаяся пыль не представляет существенной опасности до момента ее перевода в витающее (аэрозольное) состояние;

- под понятием «взрыв угольной пыли» понимается перенос фрронта пламени в среде витающих угольных частиц без существенного влияния на процесс горения других горючих веществ;

- выделяющиеся из угольной пыли газовые составляющие не ограничены метаном (и/или его гомологами - $\left.C_{n} H_{2 n+2}\right)$, существенная часть летучих имеют отличающиеся от $\mathrm{C}_{n} \mathrm{H}_{2 n+2}$ нижние концентрационные пределы воспламенения, температуру сгорания, максимальное давление взрыва и другие свойства;

- наиболее наглядным методом, фиксирующим наличие физических изменений в форме и структуре угольных частиц после взрыва, является визуальный микроскопический анализ (рисунок 3) [13,14,16]. Данным методом в сочетании с компьютерной обработкой проводится исследования динамики оплавленности частиц и их дисперсного состава вдоль аварийного участка, анализируются минимальные и средние размеры частиц (или их эквивалентные диаметры), что характеризует нарастание либо убывание процессов взрывного горения как вдоль отдельных выработок, так и в местах сопряжений и разветвлений шахтной вентиляционной сети. Электронно-микроскопический анализ угольной пыли на достаточном для практики уровне распознает резкие перепады в состоянии частиц (до очага взрыва - очаг воспламенения - после очага взрыва) и предполагает его практическое использование при уточнении фактического места возникновения взрыва. Этот метод в сочетании с анализом остаточного выхода летучих веществ может достоверно определить фракт участия угольной пыли во взрыве. Он позволяет на качественном уровне провести контроль динамики распространения УВВ и фронта пламени по выработкам аварийного участка;

- показателем, посредством которого в настоящее время пыль относится к взрывчатой, является выход летучих веществ - $V^{d a f}, \%$. При этом выход летучих веществ обозначается символом $V$ (volativ), выход на аналитическую пробу $V^{k}$, на

Таблица 1 Физические свойства горючих газов

Table 1 Physical properties of combustible gases

\begin{tabular}{|c|c|c|c|c|c|}
\hline Газ & 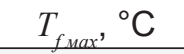 & $T_{B},{ }^{\circ} \mathrm{C}$ & НКПР,\% & ВКПР,\% & $V_{n z}, \mathrm{M} / \mathrm{c} ;{ }^{1}$ \\
\hline Водород, $H_{2}$ & 2150 & 400 & 4,0 & 75,0 & 2,70 \\
\hline Оксид углерода, $C O$ & 2100 & 550 & 12,5 & 74,0 & 0,33 \\
\hline Метан, $\mathrm{CH}_{4}$ & $1250-1950$ & 650 & 4,5 & 15,5 & 0,34 \\
\hline Этан, $C_{2} H_{6}$ & 1900 & 490 & 3,0 & 12,4 & 0,44 \\
\hline Пропан, $C_{3} H_{8}$ & 2000 & 500 & 2,1 & 9,5 & 0,39 \\
\hline Бутан, $\mathrm{C}_{4} \mathrm{H}_{10}$ & 2000 & 372 & 1,8 & 9,1 & 0,45 \\
\hline Ацетилен, $\mathrm{CH} \equiv \mathrm{CH}\left(\mathrm{C}_{2} \mathrm{H}_{2}\right)$ & $2600-3150$ & 335 & 2,5 & 81 & 13,1 \\
\hline Этилен, $\mathrm{CH}_{2}=\mathrm{CH}_{2}\left(\mathrm{C}_{2} \mathrm{H}_{4}\right)$ & 2120 & 490 & 2,7 & 36,0 & 0,63 \\
\hline
\end{tabular}


сухое вещество $V^{d}$, сухое и беззольное $V^{d a f}$; -любое термическое воздействие на угольную пыль (при температуре выше $415-425^{\circ} \mathrm{C}$ ) даже без участия пыли в процессе горения приведет к изменениям в форме и физико-химическим свойствам угольных частиц. Температура $415^{\circ} \mathrm{C}$ - экстраполированная температура начала интенсивного выделения летучих для энергетических марок углей ${ }^{3}$, для коксующихся марок углей соответствующий показатель составляет около $425^{\circ} \mathrm{C}$. Нагрев угольных частиц до указанных температур определяет начало интенсивной термодеструкции угля, часть летучих выделяется даже в случае отсутствия воспламенения пыли, что необходимо учитывать при расследовании фрактов участия пыли во взрыве по изменению значения показателя $V^{d a f}$.

\section{2. ДИНАМИКА ВЫХОДА ЛЕТУЧИХ ВЕЩЕСТВ ПРИ ВЗРЫВАХ УГОЛЬНОЙ ПЫЛИ}

Типичные экспериментальные данные по изменению величины $V^{\text {daf }}$ (до взрыва $V_{b}^{\text {daf }}$ и после взрыва $V_{a}^{\text {daf }}{ }_{a}^{4}$ приведены в таблице 2 [2,3]. Необходимо отметить, что величина выхода летучих веществ, определяемая в плановом порядке для каждого шахтопласта («пластовое» значение $\left.V^{d a f}\right)$ соответствует показателю, полученному до взрыва - $V_{b}^{d a f}$ (таблица 2). Исследователи в экспериментальных шахтах определяли $V^{d a f}$ из пыли определенного размола до взрыва и после него. То есть пыль до и после взрыва была из «тойже емкости», сравнение показателей $V_{b}^{\text {daf }}$ и $V^{\text {daf }}{ }_{a}$ в этом случае абсолютно корректно.

В работах [2,3] делается вывод о том, что убыль выхода летучих зависит от многих фракторов, определяющих процесс протекания взрыва. Среди мало известных в РФ параметров необходимо отметить влияние первоначальной мощности инициала взрыва (таблица 2; столбец «Инициал»), дисперсности пыли, а также влияние места основного пылеотложения (у кровли, на почве, в средней части сечения или на оборудовании). Однако общая тенденция - снижение выхода летучих веществ из пыли либо принявшей участие во взрыве, либо подвергнутой даже кратковременному высокотемпературному воздействию подтверждена во всех $100 \%$ опытах.

Сопоставимые результаты исследований выхода летучих после взрыва в нескольких научных центрах $[2,3,11]$ сводятся к следующему:

- чистая угольная пыль, подвергнутая высокотемпературному воздействию при взрыве имела выход летучих веществ $V^{d a f}{ }_{a}$ значительно

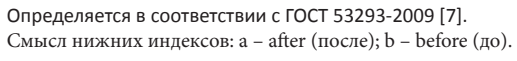

ниже показателя $V_{b}^{d a f}$ до взрыва $\left(V^{d a f}<V_{a}^{d a f}{ }_{b}\right)$;

- снижение выхода летучих веществ из пыли углей различной стадии метаморфизма после взрыва [11] находится в диапазоне от 21,6\% до 42,3\% (среднее значение 34,4 \%), аналогично по данным КД «Барбара» указанный диапазон существенно шире - от 11,9\% до 35,1\% (среднее значение $24,5 \%$ );

- значительный разброс изменения выхода летучих веществ определяется рядом факторов и не ограничен только степенью метаморфризма угля;

- для практического применения ожидаемое снижение выхода летучих веществ из угольной пыли, принявшей участие во взрыве (коксующиеся угли), составляет $1 / 4$ часть от первоначального значения ( $\left.V_{a}^{\text {daf }} \approx 0,75 \cdot V_{b}^{\text {daf }}{ }_{b}\right)[2,3]$;

- ориентировочное снижение выхода летучих веществ после взрыва для углей невысокой стадии метаморфизма (энергетические и бурые угли) может достигать $1 / 3$ от их первоначального значения $\left(V_{a}^{\text {daf }} \approx 0,67 \cdot V_{b}^{\text {daf }}\right)[2,3]$.

Ранее очевидным (как для исследователей, так и для практиков) являлся фракт принятия в качестве «абсолютно постоянной величины» $V^{d a f}$ - выход летучих веществ из пластовой пробы угля в качестве контрольного значения выхода летучих из пылеотложения во всех выработках, пройденных по рассматриваемому пласту. Необходимо отметить, что это методологически неверно. На практике $V^{d a f}$ определяется из пластового образца угля, размолотого в лабораторных условиях до максимальной величины частиц 212 мкм, с пластовой зольностью и удаленной при сушке влагой. А в горных выработках отлагается пыль с резко отличающимися значениями величины частиц и зольностью. Первоначаль-

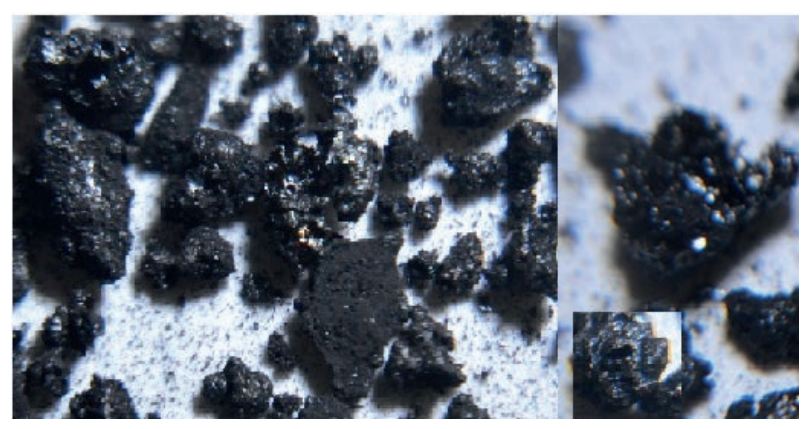

Рисунок 3 - Физические преобразования угольных частиц в эпицентре взрыва: оплавление, агрегация (слипание) и пористо-пузырчатая структура частиц - следствие интенсивного выхода летучих из угольного вещества на всю глубину прогрева

Figure 3 - Physical transformations of coal particles in

the epicenter of the explosion: melting, aggregation (coalescence) and porous-bubble structure of particles - a consequence of the intense emission of volatile from the coal substance to the entire heating depth 
Таблица 2 Выход летучих веществ из чистой угольной пыли (до и после взрыва)

Table 2 The exit of volatile substances from clean coal dust (before and after the explosion)

\begin{tabular}{|c|c|c|c|c|c|c|c|}
\hline \multicolumn{2}{|c|}{ Показатель } & \multirow{2}{*}{ Инициал } & \multicolumn{2}{|c|}{ Выход летучих веществ } & \multirow{2}{*}{$\begin{array}{c}\text { Внешняя } \\
\text { влага до } \\
\text { взрыва, \% }\end{array}$} & \multirow{2}{*}{$\begin{array}{c}\text { Снижение } V^{d a f} \text {, } \\
\text { (абсолютное } \\
\text { значение) }\end{array}$} & \multirow{2}{*}{$\begin{array}{c}\text { Снижение } V^{\text {daf }}{ }_{a} \mathrm{\kappa} \\
V_{b}^{\text {daf }}, \%\end{array}$} \\
\hline$d, \%$ & $C,\left\ulcorner/ \mathrm{M}^{3}\right.$ & & $\begin{array}{c}\text { до взрыва } \\
V^{\text {daf }}{ }_{b} \%\end{array}$ & $\begin{array}{c}\text { после взрыва } \\
V^{\text {daf }}{ }_{a} \% \\
\end{array}$ & & & \\
\hline 1 & 2 & 3 & 4 & 5 & 6 & 7 & 8 \\
\hline \multicolumn{8}{|c|}{ Сухая угольная пыль шахты Барбара } \\
\hline 25 & 135 & $50 \mathrm{M}^{3} \mathrm{CH}_{4}$ & 41,1 & 36,2 & - & на $4.9 \%$ & 11,9 \\
\hline 25 & 261 & НП & 40,5 & 31,4 & - & на $9.1 \%$ & 22,5 \\
\hline \multicolumn{8}{|c|}{ Мокрая угольная пыль шахты Барбара } \\
\hline 85 & 500 & $50 \mathrm{~m}^{3} \mathrm{CH}_{4}$ & 41,6 & 27,0 & 34,2 & на14.6\% & 35,1 \\
\hline 25 & 1125 & $30 \mathrm{mPII}$ & 41,0 & 30,3 & 25,1 & на $10.7 \%$ & 26,1 \\
\hline \multicolumn{8}{|c|}{ Сухая чистая пыль (бурый уголь) шахты Сенява } \\
\hline 85 & 500 & $50 \mathrm{M}^{3} \mathrm{CH}_{4}$ & 66,8 & 48,0 & - & на18.8\% & 28,1 \\
\hline 25 & 625 & $30 \mathrm{mPII}$ & 60,1 & 46,1 & - & на14.0\% & 23,3 \\
\hline \multicolumn{6}{|c|}{ Среднее снижение выхода летучих веществ, \% } & $12 \%$ & 24,5 \\
\hline
\end{tabular}

но образованная пыль имеет технологическую зольность (как правило - выше пластовой), но по мере перемещения пыли воздушным потоком из аэрозоля опережающими темпами осаждаются более тяжелые минеральные добавки (породная пыль), а частицы угля с незначительной остаточной зольностью осаждаются на дальнейшем протяжении горных выработок. Кроме резкого изменения зольности по мере удаления от комбайна существенно изменяется дисперсный состав отлагающейся пыли: крупные фракции пыли осаждаются быстрее, а мелкая пыль переносится на большие расстояния. Поэтому сопоставление «пластовой» $V^{d a f}$ с аналогичным показателем для пыли, отложившейся в выработке, не вполне корректно. Это пробы пыли «из разных ёмкостей» то есть разного размола, зольности и влажности, определенные в разные периоды времени, общим для которых является только марка угля и пласт. Выход летучих веществ в конвейерных выработках и верхней части сечения лав (до аварии) может существенно или заметно превышать «пластовое» значение $V^{d a f}$, решающим фрактором здесь является дисперсный состав пыли.

\section{3. ИСЛЕДОВАНИЯ ДИНАМИКИ ВЫХОДА ЛЕТУЧИХ ВЕЩЕСТВ НА ПРИМЕРЕ АВАРИЙ ПОСЛЕДНЕГО ПЕРИОДА}

Как отмечено выше, применение в действующих нормативах показателя $V^{\text {daf }}$ предус- матривает пересчет массы выхода летучих веществ из аналитической пробы $\left(V^{\hbar}, \%\right)$ на сухую беззольную массу (с.б.м.) - $V^{d a f}, \%$. При помощи данного приема в значительной степени исключается влияние негорючих добавок и воды (влаги) на величину выхода летучих из рассматриваемой марки угля.

Одновременно с этим до настоящего времени на нормативном уровне не учтен один из наиболее существенных фракторов - влияние дисперсного состава пыли на выход летучих веществ. Несмотря на широко опубликованные данные об изменении взрывчатых свойств мелких (менее 20 мкм) фракций угольной пыли $[15,19]$ и экспериментальном подтверждении резкого роста показателя $V^{\text {daf }}$ мелкой пыли $[10,20]$, в условиях плановых определений $V^{d a f}$ исследуется «аналитическая проба, измельченная до максимального размера частиц 212 мкм» [6].

Отлагающаяся в современных высокопроизводительных шахтах пыль исследована авторами, выводы сводятся к следующим положениям:

- основу отложений угольной пыли ${ }^{5}$ в лавах, выемочных участках и подготовительных выработках составляют частицы с эквивалентным диаметром менее 50 мкм, наиболее распространенный размер отложившихся частиц угольной пыли в лавах составляет 25-27 мкм. Отдельные витающие частицы размерами до 180 мкм 
наблюдаются на расстоянии до 8 метров от места резания угля, их доля в общей массе пыли не превышает 0,1 \% (при нормативном требовании - размол до 212 мкм [6]);

- дисперсный состав отложившейся пыли близок к постоянному только на протяжении выемочной выработки и существенно отличается по сети горных выработок за пределами лав.

Наиболее наглядный пример $[2,3,10]$ по резкому изменению взрывчатости пыли при более тонком размоле продемонстрирован во время полномасштабного (LST) взрыва №680 на опытной шахте КД «Барбара». Плановое определение показателя $V^{d a f}$ составило 11,5\%. Это значение $V^{\text {daf }}$ было установлено на аналитической пробе с максимальным размером частиц около 212 мкм - пыль $d 25$ по классификации КД «Барбара». Однако при взрыве была использована пыль более тонкого размола (d85) с величиной удельной поверхности $F>8410 \mathrm{~cm}^{2} / \Gamma$, что приближенно соответствует рассеву на сите с величиной ячеек 30 мкм. Выход летучих веществ для пыли с размолом $d 85$ вырос с $11,5 \%$ до $27 \%$ и вместо слабого затухающего взрыва было получено детонационное горение угольной пыли, редко достигавшееся даже для углей со значительно большим значением $V^{d a f}$.

Для исследований, указанных выше, процессов после произошедшего взрыва (рисунок 4) были отобраны пробы пыли в контрольных точках аварийного участка (№1-№18, рисунок 5), а также пробы кускового угля в 2-х точках участка (№19,№20, рисунок 5). В шахте до взрыва применялась обмывка угольной пыли и полученная для анализа пыль не содержала сланцевых примесей.

В шахтной вентиляционной сети рельсовый уклон РУ $35 ю$ пл.Тройной (рисунок 5) был связан скважиной с ЮКНШ пл.4 гор.-780м, имевшей высокое аэродинамическое сопротивление, и формирование взрыва произошло таким образом, что движение УВВ и фронта пламени отмечено только в одном направлении ${ }^{6}$.

В соответствии с материалами расследования аварии первоначальной версией предполагалось, что взрыв произошел в районе лаве 832ю (рисунок 5) 7 . Впоследствии по характеру разрушений местом взрыва определен рельсовый уклон 35-ю пласта Тройного в районе камеры привода ленточного конвейера 1Л-120 (рисунок 5), что полностью подтверждается методом сопоставлении остаточного выхода летучих из проб пыли:
- явно выделен факт того, что в замерной точке 10 (рисунок 5) отмечен максимальный выход летучих веществ из отложившейся пыли и максимальное процентное содержание тонких фракций пыли;

- за очагом взрыва (точка 11) происходит существенное снижение остаточной величины выхода летучих веществ на протяжении 160 метров вдоль аварийной выработки (РУ) до сопряжения с КШ $35 ю$ пл.Тройной и далее на протяжении РУ не менее 300 метров;

- на протяжении около 400 метров вдоль конвейерного штрека КШ $35 ю$ пл.Тройной и после поворота УВВ под углом около 90 градусов величина остаточного выхода летучих изменялась, но была намного ниже, чем в точке 10.

Параметры отложившейся пыли по ходу распространения ударной взрывной волны (УВВ) непосредственно в аварийной выработке приведены в таблице 3 и на рисунке 6. Изменение выхода летучих в конвейерном штреке после поворота УВВ под углом $\approx 90^{\circ}$ приведены на рисунке 7.

Необходимо отметить, что параметр $\mathrm{V}^{\mathrm{a}}$ определен на термовесах ТГА-951 в составе термоанализатора фирмы DuPont ${ }^{8}$, а нетрадиционным способом в муфельной печи. Поскольку определение выхода летучих веществ существенно зависит от применяемой аппаратуры, то отмечена разница в показаниях: величина «пластового» значения выхода летучих веществ из угля марки «Ж» $V^{d a f}=32,6 \%$ (в муфельной печи) соответствует величине $V^{t}=40,9 \%$ для ТГА-951, коэффицциет пересчета показаний составил 0,797 .

Как видно из данных таблицы 3 и рисунка 6 , величина выхода летучих веществ из отложившейся в горной выработке пыли (значение $V^{d a f}=43,5$ в точке 10) может заметно превышать определенное для нормативного размола значение (из пробы угля) $V^{d a f}=40,5 \%$. В рассмотренном случае выход летучих из шахтной пыли был выше на 6,4\%. Далее по длине рельсового уклона (переход от точки №10 к точке №11) отмечено резкое снижение выхода летучих веществ из отложившейся пыли в 2,24 раза. Указанное снижение выхода летучих сопровождалось наличием массы оплавленных слипшихся угольных частиц, имевших пористую или пузырчатую структуру (приведено ранее на рисунке 3). Образование пористой структуры у частиц является следствием интенсивного выделения газов из угольного вещества на всю глубину прогрева до темпера-

\footnotetext{
6 Материалы Дополнительного расследования группового несчастного случая, связанного с аварией, произошедшей 01.02 .2013 года в СП «Шахта Воркутинская» Экспертной группой также рассматривалась версия взрыва в районе сопряжения лавы 832ю пл. Тройного и Конвейерного штрека 832ю пл. Тройного, вызванного отсутствием фильтра пламени в выхлопной системе дизелевоза.

8 Термогравиметрические измерения проводились на лабораторной базе отделов 3.1 и 3.4 ФГБУ ВНИИПО МЧС России. 


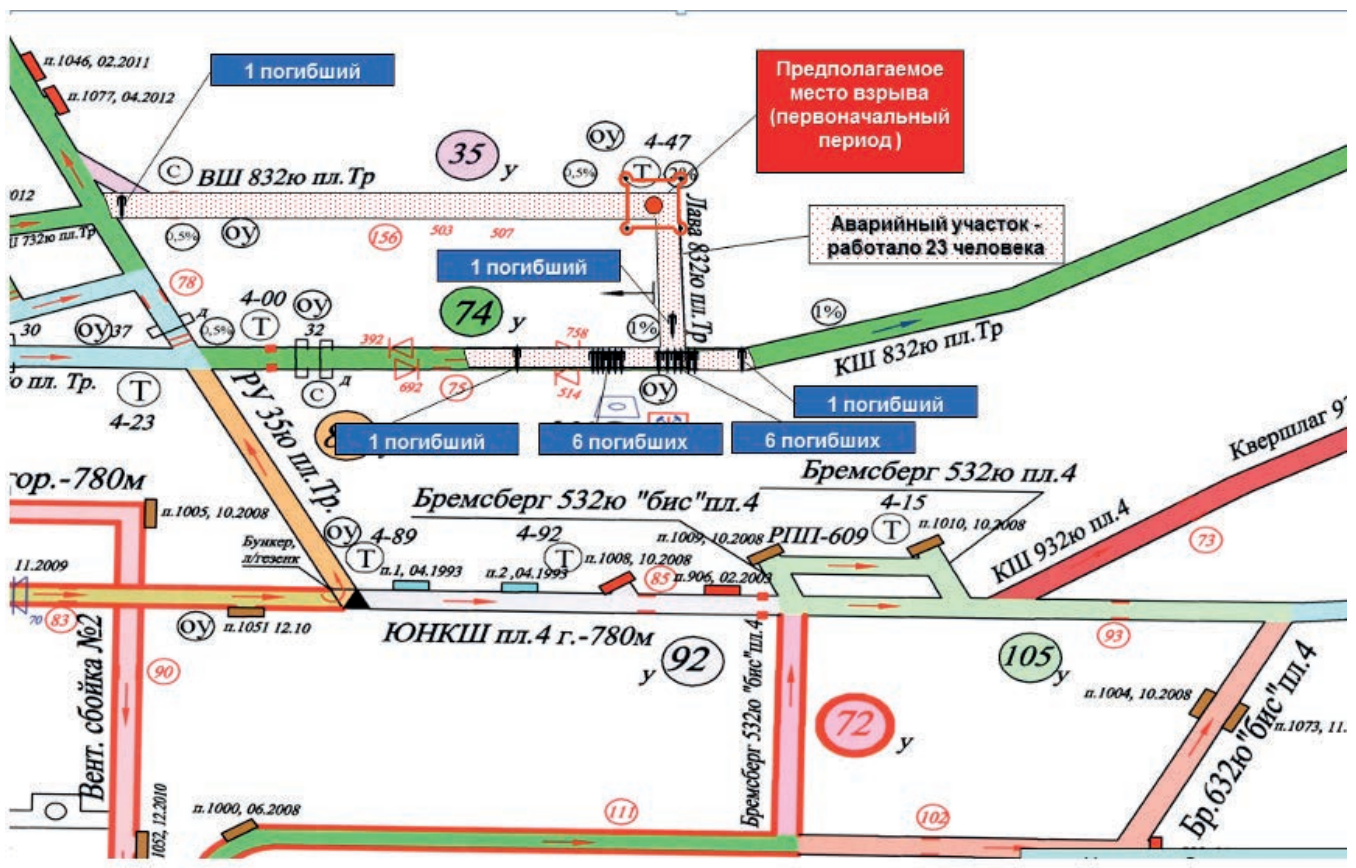

Рисунок 4 - Первоначальный период ликвидации аварии

(фррагмент ОПЛА по ш. «Воркутинская» от 11.02.2013 2, вид аварии - «Взрыв»)

Figure 4 - The initial period of the accident liquidation

(fragment of the OPLA on the Vorkutinskaya mine dated 02/11/2013, type of accident - "Explosion")

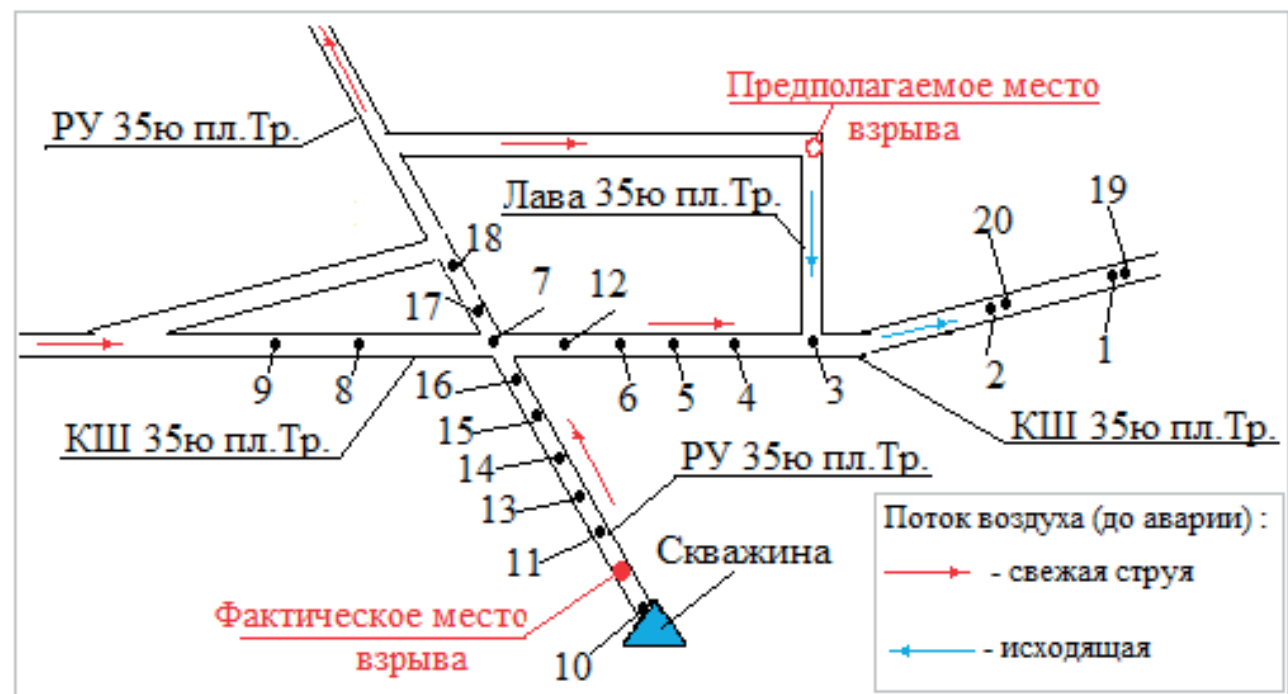

Рисунок 5 - Схема отбора проб пыли (точки 1-18) и проб угля (точки 19,20)

Figure 5 - Diagram of dust (points 1-18) and coal sampling (points 19,20)

тур выше $415^{\circ} \mathrm{C}$. Далее по ходу УВВ (точки контроля №13-№18, рисунок 5) отмечен неустойчивый характер взрывного горения на стадии формирования «волны давления» ${ }^{9}$. В этой части аварийного участка ${ }^{10}$ происходило первичное горение пыли (то есть горение летучих веществ без горения углерода) при недостатке кислорода. На этом участке интенсивность горения неустойчива, и рост параметров взрыва (максимального давления взрыва и скорости пламени) сопровождается их периодическим снижением до $20-25 \%$. Частичное снижение интенсивности горения, в свою очередь, влечет уменьшение выхода летучих веществ из пыли, и остаточный выход летучих возрастал в точках №14-№16 (по отношению к точке №11) в 1,20-1,22 раза.

В месте сопряжения РУ и конвейерного штрека КШ 832ю пл. Тройной отмечен резкий всплеск интенсивности горения за счет дополнительной подачи кислорода и, соответственно, снижение остаточного выхода летучих из пыли в точке №7 (рисунок 6, рисунок 5). Далее УВВ распространилась в 3-х направлениях:

- прямолинейно к точке №18 с сохранени-

9 Детально процессы перехода от диффузионного к дефлаграционному горению при взрывах пыли в горных выработках рассмотрены в работе [19].

10 Как правило, зона формирования взрыва составляет 110-140 м от места первоначальной вспышки. 
Таблица 3 Граничные размеры частиц пыли и величина выхода летучих веществ в контрольных точках по длине аварийной выработки (участок 10-7-18, рисунок 5)

Table 3 Boundary sizes of dust particles and the volume of volatile substances' emission at control points along the accident affected working(section 10-7-18, Figure 5)

\begin{tabular}{|c|c|c|c|c|c|c|c|c|c|}
\hline \multirow{2}{*}{$\begin{array}{c}\text { Параметр, } \\
\text { ед. } \\
\text { измерений }\end{array}$} & \multicolumn{9}{|c|}{ Значение параметров в контрольных точках: } \\
\hline & уголь & 10 & 11 & 13 & 14 & 15 & 16 & 7 & 18 \\
\hline $\mathrm{L}_{\min }, M K M$ & - & 0,5 & 4,6 & 2,3 & 1,3 & 4,1 & 1,2 & 0,6 & 1,2 \\
\hline $\mathrm{L}_{\max }, \mathrm{MKM}$ & - & 140 & 282 & 95 & 122 & 238 & 208 & 133 & 163 \\
\hline $\mathrm{L}_{c p}, \mathrm{MKM}$ & - & 2,0 & 32,0 & 7,8 & 11,8 & 13,3 & 11,5 & 6,0 & 10,0 \\
\hline$\varnothing_{c p^{\prime}} M K M$ & - & 1,6 & 24,8 & 6,1 & 9,1 & 10,3 & 9,0 & 4,7 & 7,6 \\
\hline$V^{a}, \%$ & 40,9 & 43,5 & 19,4 & 21,8 & 26,4 & н/Д & 26,2 & 21,6 & H/Д \\
\hline $\mathrm{V}^{\mathrm{daf}}, \%$ & \multicolumn{9}{|c|}{ 32,6 (из пластовой пробы угля для d $\leq 212$ мкм; муфельная печь) } \\
\hline
\end{tabular}

ем интенсивности горения и низким значением остаточной величины выхода летучих;

- под углом 90 по ходу вентиляционной струи с сохранением общих тенденций (снижение интенсивности горения при недостатке кислорода - от точки 7 - к точке 5) и резкой его интенсификацией в районе сопряжения с лавой (точка 3, рисунок 7);

- под углом 90 против хода вентиляционной струи (точки 8 и 9, рисунок 5)

\section{5. ВЫХОД ЛЕТУЧИХ ВЕЩЕСТВ ИЗ} СЛАНЦЕВОЙ И ОСЛАНЦОВАННОЙ УГОЛЬНОЙ ПЫЛИ

В ходе расследований при авариях вопрос об участии угольной пыли во взрыве существенно осложняется применением осланцевания горных выработок. Данные по изменению выхода летучих веществ до и после взрыва из осланцованной угольной пыли приведены в таблице $4[2,3]$.

Данные таблицы 4 указывают на существенный разброс в изменении показателя $V^{d a f}$ (до взрыва и после) от 5,8\% до 39,8\% (для «чистой» угольной пыли эти показатели были от 11,9\% до 35,1\%). При этом пробы из таблицы 4 содержали добавку инертной пыли, позволявшую провести ее взрыв. После взрыва во всех случаях выход летучих веществ сокращался однако пересчет данных показателей на сухую беззольную массу (с.б.м.) - то есть получение именно показателя $V^{\text {daf }}$ искажалось: в муфельной печи оставшаяся после взрыва часть известняка выделяла $\mathrm{CO}_{2}$, вычесть массу $\mathrm{CO}_{2}$ из объема горючих газов при существующей технологии определения $V^{\text {daf }}$ невозможно, а из массы остатка (при пересчете на с.б.м.) вычиталась вся зола, включая остатки $\mathrm{CaCO}_{3}$ и вновь образованный $\mathrm{CaO}$. Величина $V^{\text {daf }}$ из проб пыли с содержанием минеральных

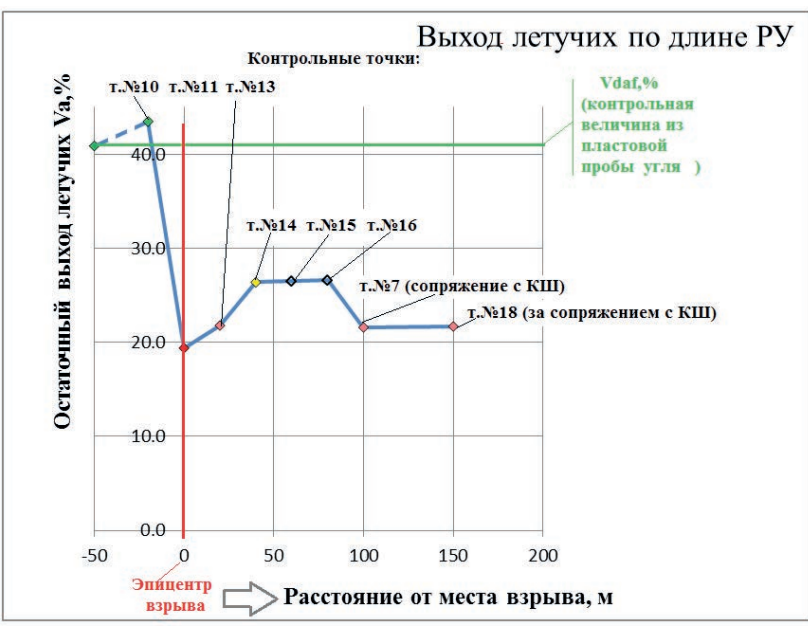

Рисунок 6 - Изменение выхода летучих веществ из пыли вдоль аварийной выработки

Figure 6 - Change in the volatile substances' emission from dust along the accident affected working

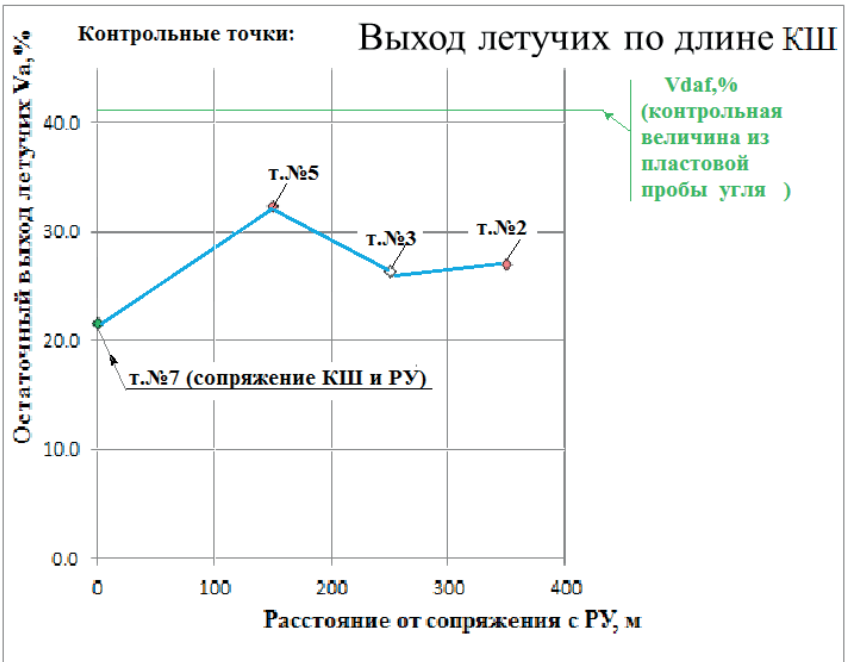

Рисунок 7 - Выход летучих веществ из пыли в конвейерном штреке (после поворота УВВ под углом $\approx 90^{\circ}$ по ходу вентиляционной струи)

Figure 7 - The volatile substances' emission from dust in the conveyor gallery (after ESW turning at an angle of $\approx 90$ - along the air stream) 
Таблица 4 Выход летучих веществ из осланцованной угольной пыли (до и после взрыва)

Table 4 The volatile substances' emission from shale coal dust (before and after the explosion)

\begin{tabular}{|c|c|c|c|c|c|c|c|}
\hline \multicolumn{3}{|c|}{ Показатель } & \multirow{2}{*}{ Инициал } & \multicolumn{2}{|c|}{ Выход летучих веществ } & \multirow{2}{*}{$\begin{array}{c}\text { Снижение } V^{d a f} \text {, } \\
\text { абсолютное } \\
\text { значение) }\end{array}$} & \multirow{2}{*}{$\begin{array}{c}\text { Снижение } V^{d a f}{ }_{a} \text { к } \\
V_{b}^{d a f}, \%\end{array}$} \\
\hline$d, \%$ & $n, \%$ & $C, г / \mathrm{M}^{3}$ & & $\begin{array}{c}\text { до взрыва } \\
V_{b}^{d a f}, \%\end{array}$ & $\begin{array}{c}\text { после взрыва } \\
V^{\text {daf }}, \%\end{array}$ & & \\
\hline 1 & 2 & 3 & 4 & 5 & 6 & 7 & 8 \\
\hline \multicolumn{8}{|c|}{ Мокрая угольная пыль шахты Барбара ( $W=11,2 \%-8,2 \%)$} \\
\hline 25 & 30,0 & 2000 & $50 \mathrm{~m}^{3} \mathrm{CH}_{4}$ & 42,5 & 40,0 & 2,5 & 5,8 \\
\hline \multicolumn{8}{|c|}{ Сухая угольная пыль шахты Гливице, пласт 123} \\
\hline 85 & 72,5 & 600 & $50 \mathrm{M}^{3} \mathrm{CH}_{4}$ & 32,0 & 17,3 & 12,7 & 39,8 \\
\hline \multicolumn{8}{|c|}{ Сухая угольная пыль шахты Гливице, пласт 152} \\
\hline 25 & 65,0 & 950 & $50 \mathrm{~m}^{3} \mathrm{CH}_{4}$ & 34,4 & 29,6 & 4,8 & 14,0 \\
\hline \multicolumn{8}{|c|}{ Сухая угольная пыль шахты Марцел, пласт 708} \\
\hline 85 & 60,0 & 800 & $30 \mathrm{mPII}$ & 41,6 & 29,8 & 11,8 & 28,4 \\
\hline \multicolumn{8}{|c|}{ Сухая угольная пыль шахты Мешко, пласт 25/27 } \\
\hline 85 & 46,0 & 750 & $50 \mathrm{M}^{3} \mathrm{CH}_{4}$ & 15,3 & 11,5 & 3,8 & 24,8 \\
\hline 85 & 58,7 & 750 & $30 \mathrm{mPII}$ & 15,5 & 14,5 & 1,0 & 6,5 \\
\hline 25 & 30,0 & 1000 & $50 \mathrm{M}^{3} \mathrm{CH}_{4}$ & 16,5 & 10,7 & 5,8 & 35,1 \\
\hline 25 & 38,5 & 750 & 30 mPII & 15,1 & 10,9 & 4,2 & 27,8 \\
\hline \multicolumn{8}{|c|}{ Сухая угольная пыль шахты Мшана, пласт 11} \\
\hline 25 & 60,0 & 900 & $50 \mathrm{M}^{3} \mathrm{CH}_{4}$ & 37,4 & 29,4 & 8,0 & 21,4 \\
\hline 25 & 65,0 & 900 & $30 \mathrm{mPII}$ & 37,1 & 31,6 & 5,5 & 14,8 \\
\hline \multicolumn{7}{|c|}{ Среднее снижение выхода летучих веществ, \% } & 21,8 \\
\hline
\end{tabular}

*Переменные, принятые в обозначениях в таблицах 1 и $2: d-; n-; W$ - влажность пыли; $C$ - концентрация отложившейся пыли в выработке до взрыва в пересчете на 1 м³ объема; Инициал «НП» - непосредственный инициал взрыва при помощи пороха.

компонент («зольностью») выше 10\% будет существенно завышена или некорректна. Смешивание угольной пыли со сланцевой качественно и количественно изменяет состав летучих веществ, динамику их выхода и объем выделяющихся газов.

При исследовании изменений в выходе летучих веществ из смеси угольной и сланцевой пыли необходимо учитывать, что такая смесь содержит, как правило, не менее $80 \%$ инертной пыли, основу которой составляют соединения кальция - известняк или карбонат кальция. Карбонат кальция имеет достаточно высокую насыпную плотность (для размолотого состояния

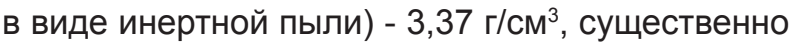
превышающую как плотность угля (около 1,4 г/ $\mathrm{cm}^{3}$ ) так и среднюю насыпную плотность уголь-

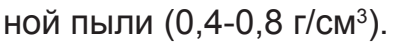

При температуре $500^{\circ} \mathrm{C}$ и выше происходит термическое разложение известняка:

$$
\mathrm{CaCO}_{3} \rightarrow \mathrm{CaO}+\mathrm{CO}_{2}
$$

Температура термического разложения известняка $\left(500^{\circ} \mathrm{C}\right)$ попадает в интервал реакции выхода летучих веществ из угля $\left(345^{\circ} \mathrm{C}-650^{\circ} \mathrm{C}\right)$. В результате химической реакции (1) образуется твердое кристаллическое вещество - оксид кальция $\mathrm{CaO}$ и выделяется углекислый газ. Исходя из соотношения молярной массы карбоната кальция и оксида кальция при полном завершении процесса термодеструкции $\mathrm{CaCO}_{3}$ ожидаемый выход летучих за счет выделения инертного газа $\mathrm{CO}_{2}$ должен составить около $44 \%$. Экспериментальное определение выхода $\mathrm{CO}_{2}$ из карбоната кальция показывает, что потеря массы образцов за 7 минут изотермического нагрева в муфельной печи ${ }^{11}$ (аналогично нагреву угольной пыли) составляет $42-43 \%$ и не увеличивается при дальнейшем нахождении образцов в печи (до 15 минут). Сопоставительные графики потери массы образцов угольной (марка «Ж») и сланцевой пыли приведены на рисунке 8.

Необходимо отметить, что измерение убывания массы образцов угольной пыли проводилось с шагом 1 секунда, а для $\mathrm{CaCO}_{3}-$ с шагом 7 минут, что не позволяет определить интервал максимального выхода инертного $\mathrm{CO}_{2}$ из сланцевой пыли. Вместе с этим ясно, что химическая реакция (1) протекает достаточно быстро (в области резкого падения кривых 1-4 на первой минуте нагрева) и приводит к разложению инертной пыли на твердый оксид кальция и газообразный $\mathrm{CO}_{2}$. 


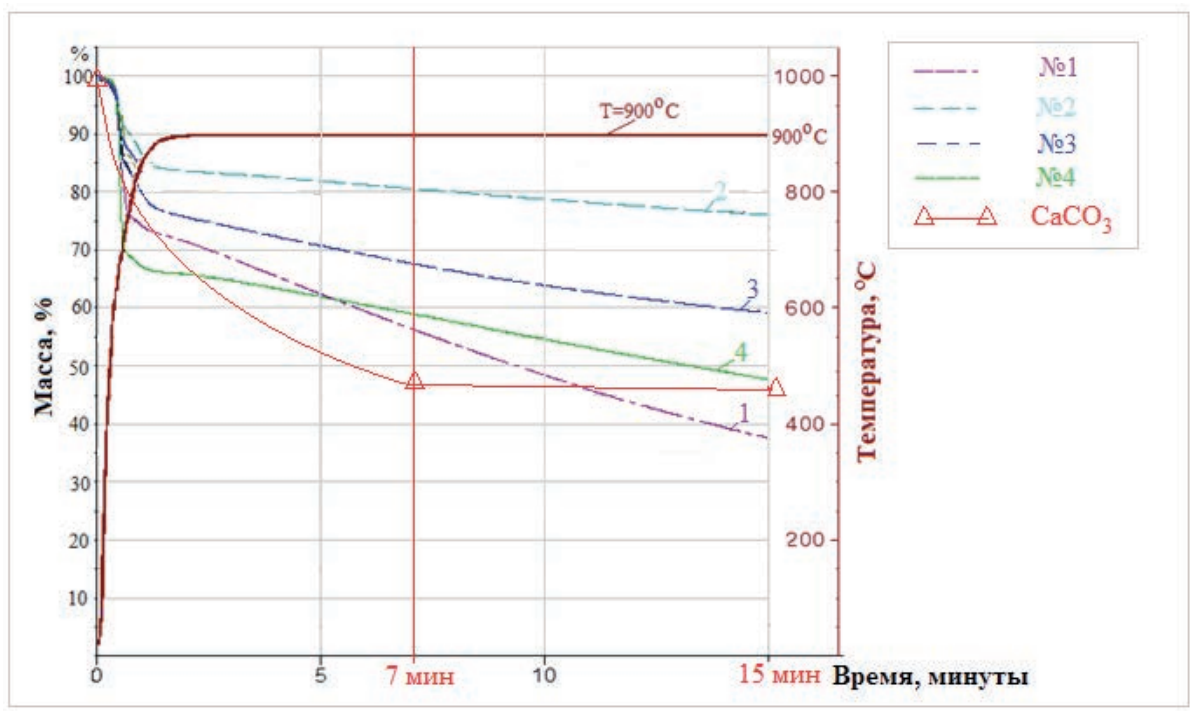

Рисунок 8 - Сопоставление термогравиметрических кривых (ТГ) пыли угля марки «Ж» (кривые 1,2,3,4.) и аппроксимированной кривой потери массы сланцевой пылью

Figure 8 - Comparison of thermogravimetric curves (TG) of grade "Zh" coal dust (curves 1,2,3,4.) and the approximated curve of mass loss by shale dust

С учетом сделанных замечаний и экспериментальных работ необходимо сделать вывод о невозможности достоверного определения фракта участия во взрыве осланцованной угольной пыли по динамике выхода летучих веществ. Как угольная, так и сланцевая пыль при нагреве выше $415^{\circ} \mathrm{C}-500^{\circ} \mathrm{C}$ выделяют летучие вещества. Поэтому сопоставление остаточной величины выхода летучих из шахтной осланцованной пыли с «пластовой» величиной обогащенного (для зольности не выше 10\% по ГОСТ Р 556602013) показателем $V^{d a f}$ не имеет практического смысла. Применение сланцевой пылевзрывозащиты требует принципиально нового подхода и новой методики по отбору, подготовке проб (возможно разделение угольной и сланцевой пыли) и значительного объема экспериментальных работ для основных марок углей при различных концентрациях сланцевой пыли в смесях.

\section{ЗАКЛЮЧЕНИЕ}

Ретроспективный анализ уровня научноисследовательских работ в области пылевзрывобезопасности горного производства за период с 1985 года позволяет сделать вывод об их ориентации на получение «мгновенного» результата без получения новых знаний в области взрывчатости угольной пыли и смежных областях. Казалось бы назревшая проблема (к середине 80-х годов прошлого века) ускорения передачи в промышленное использование результатов НИР привела к побочному эфффекту - многолетней модификации ранее полученных данных и введению в действие ряда нормативов или тех- нических решений без необходимого объема де-фракто исследовательских работ. Научный потенциал в значительной степени устаревает, знаменитая латинская фрраза «Non progredi est regredi' ${ }^{12}$ » в принципе ясна без перевода.

Одновременно с этим даже ограниченные объемы современных исследований на новой лабораторной базе существенно дополняют ряд ранее признанных «не подлежащих сомнению истин». Требуется систематизация исследовательских работ и их практическое внедрение на уровне норм и технологий. Основные результаты в области методов определения участия угольной пыли во взрыве, изложенные в настоящей публикации, сводятся к следующему:

1. При анализе взрыва «чистой», или неосланцованной угольной пыли, динамика показателя остаточного выхода летучих веществ достоверно позволяет определить место возникновения взрыва и динамику его распространения по сети выработок. Отмечено снижение в 2,24 раза показателя остаточного выхода летучих веществ в очаге взрыва по отношению к аналогичному показателю до места взрыва.

2. Контрольное значение выхода летучих веществ из размолотой в лаборатории «пластовой» пробы угля может не совпадать с выходом летучих веществ из пыли, реально отложившейся в шахте до аварии. В штреках и транспортных выработках отлагается пыль, имеющая значительно меньшие размеры, чем лабораторный размол по ГОСТ Р 55660-2013. Поэтому рекомендуется определять величину выхода летучих веществ из шахтного пылеотложения (лава, 
штрек с исходящей струей воздуха, конвейерная выработка) в качестве дополнения к плановоопределяемому «пластовому» $V^{\text {daf }}$. Указанные дополнительные величины необходимо определять до аварии для возможного использования в качестве контрольных значений при расследовании аварий.

3. Динамика параметров взрывного горения на начальном этапе взрыва (110-140 м от очага взрыва) носит нелинейный и немонотонный характер. В первую очередь такие процессы объяснимы химической реакцией горения в условиях недостатка кислорода, что сопровождается скачкообразным увеличением-снижением скорости пламени и максимального давления взрыва. Эти процессы находят свое отражение в динамике остаточного выхода летучих веществ из пыли аварийного участка (по длине выработок рисунок 6, рисунок 7).

4. В ходе расследования аварий необходимо детально спланированное проведение отбора проб (порядка 20-30 проб суммарно) из всех выработок аварийного участка и прилегающих выработок. Это позволит методом сопоставления остаточной величины выхода летучих веществ определить эпицентр взрыва, направление движения УВВ и её динамику.

5. Во всех открытых литературных источниках отсутствуют сведения о характере изменения параметров взрыва в точках сопряжения выработок при реальной системе вентиляции. Это обусловлено тем, что экспериментальные шахты исследовали взрывы только в пределах одного штрека или группы соединенных последовательно штреков (прямолинейных или соединенных под различными углами). Таким образом, в ходе описанных в настоящей статье результатов, впервые удалось исследовать динамику взрывного горения угольной пыли в сети горных выработок при действующей системе шахтной вентиляции. Исследованы параметры взрыва вдоль выработок, в местах разветвлений и сопряжений выработок, а также дальнейший характер развития взрыва при движении УВВ как «по ходу вентиляционной струи», так и «против струи». В точках сопряжения горных выработок (точки №7 и №3, рисунок 5) за счет наличия подсвежающей струи или дополнительных объемов кислорода происходило резкое увеличение интенсивности горения, остаточное значение $V^{d a f}$ при этом снижалось в среднем на 1/5 часть от его значения в предыдущей точке контроля.

6. При повороте УВВ под углом $90^{\circ}$ при движении взрыва по ходу вентиляционной струи (от точки №7 к точкам №3 и далее к точке №1, рисунок 5) не отмечено сокращения интенсивности взрывного горения за счет сил трения и местного сопротивления поворота. А с учетом фракта увеличения интенсивности горения в местах сопряжения горных выработок возможно утверждать, что на стадии развития взрыва пыли наличие поворота под углом $90^{\circ}$ не является элементом пассивной защиты от поражающих факторов взрыва, что согласуется с местом расположения смертельно травмированных горнорабочих (рисунок 4). Силы сопротивления трения и местные сопротивления поворотов начнут оказывать пассивное защитное действие только за пределами зоны горения пыли и газов.

7. При повороте УВВ под углом $90^{\circ}$ и движении взрыва против хода вентиляционной струи (от точки №7 к точкам №8 и №9) на основе компьютерно-микроскопического анализа выявлены существенные отличия в характере дисперсного состава пыли в точках № 8 и №9 по отношению к точке №7 и точкам №1-№5.

8. Инертная пыль $\left(\mathrm{CaCO}_{3}\right)$ при нагреве до $500^{\circ} \mathrm{C}$ выделяет летучие вещества, что приводит к изменению физико-химического состава смеси. Выход летучих из $\mathrm{CaCO}_{3}$ будет происходить, однако в отличие от летучих из угля летучие из осланцованной пыли будут содержать около $80 \% \mathrm{CO}_{2}$ - инертного газа, а из «чистого» угольного вещества выделяется до 97\% горючих составляющих. Осланцованная до 80-90\% пыль не удовлетворяет требованиям ГОСТ Р 556602013 по максимально допустимой зольности, поэтому сопоставление остаточной величины выхода летучих из шахтной осланцованной пыли с «пластовой» величиной обогащенного (для зольности не выше 10\% по ГОСТ Р 55660-2013) показателем $V^{\text {daf }}$ не имеет практического смысла. 9. Применение сланцевой пылевзрывозащиты требует принципиально нового подхода и разработки новой методики по порядку отбора, подготовке проб (разделение угольной и сланцевой пыли) и значительного объема экспериментальных работ для основных марок углей при различных концентрациях сланцевой пыли в смесях.

\section{СПИСОК ЛИТЕРАТУРЫ}

1. Fatal Underground Mine Explosion, April 5, 2010. Performance Coal Company Upper Big Branch Mine-South Massey Energy Company Mine ID: 46-08436:. Mine Safety and Health Administration. December 6, 2011

2. Cybulski W. Wybuchy pylu weglowego i ich zwalczanie. Katowice, Wydaw. "Slask"., 1973.- 451 c.

3. Lebecki K. Zagrożenia pylowe w górnictwie. Katowice: Glowny Instytut Górnictwa, 2004.- 399 c. 
4. Агроскин А.А. Физические свойства угля. М.: «Государственное НТИ по черной и цветной металлургии».1961.308 c.

5. Ван Кревелен Д.В. Свойства и химическое строение полимеров. М.: Химия, 1976.-416 с.

6. Национальный стандарт РФ ГОСТ Р 55660-2013 Топливо твердое минеральное. Определение выхода летучих веществ. - М.: ФГУП «Стандартинформ».-2014.-17 с.

7. ГОСТ Р 53293-2009. Пожарная опасность веществ и материалов. Материалы, вещества, и средства огнезащиты. Идентификация методами термического анализа.

8. ГОСТ 12.1.041-83.Пожаровзрывобезопасность горючих пылей. Общие требования.

9. ГОСТ 12.1.044-89. Пожаровзрывоопасность веществ и материалов. Номенклатура показателей и методы их определения.

10. Лебецки К.А. Романченко С.Б. Пылевая взрывоопасность горного производства. -М.: Горное дело, $2012 .-464$ с.

11. Нецепляев М.И., Любимова А.И., Петрухин П.М.. Борьба со взрывами угольной пыли в шахтах. М.: Недра, 1992. - 298 c.

12. Романченко С.Б. Экспериментальные и теоретические исследования взрывоопасных рудничных аэрозолей/ Романченко С.Б., Гендлер С.Г., Тимченко А.Н., Костеренко В.Н.// В сб. ГИАБ, специальный выпуск №5-1, 2017. c181-190

13. Уэндландт У. Термические методы анализа. - М.: Мир, 1978. - 526с.

14. Gomes da Silva G. A Thermogravimetric Analysis of the Combustion of a Brazilian mineral Coal/ Quim. Nova, Bып. 31, № 1, с. 98-103, 2008.

15. Романченко С.Б., Девликанов М.О. Влияние дисперсного состава угольной пыли на показатели взрывоопасности.// Вестник научного центра по безопасности работ в угольной промышленности. - № 2-2019, с.16-23.

16. Романченко С.Б., Трубицин А.А. Микроскопический метод анализа степени участия пыли во взрывах.// Вестник научного центра по безопасности работ в угольной промышленности. - 2019. №3. С.6-14.

17. Хлудов Д.С. и др. К вопросу о методике определения участия угольной пыли во взрыве метановоздушной смеси. // Вестник научного центра по безопасности работ в угольной промышленности. - № 1-2014, с.150-155.

18. Ботвенко Д. В. Методические рекомендации по определению степени участия угольной пыли во взрыве / Д. В. Ботвенко, С. И. Голоскоков, Н. М. Недосекина // Вестник научного центра по безопасности работ в угольной промышленности. - № 1, 2016. С 125-130.

19. Романченко С.Б., Костеренко В.Н. Полномасштабные исследования взрывов угольной пыли и критерии эфрфективности средств локализации.// Вестник научного центра по безопасности работ в угольной промышленности. - 2018. №4. С.6-20.

20. Романченко С.Б., Руденко Ю.Ф., Костеренко В.Н. Пылевая динамика в угольных шахтах.-М.: Горное дело, 2011.-256 c.

\section{REFERENCES}

1. Fatal Underground Mine Explosion, April 5, 2010. Performance Coal Company Upper Big Branch Mine-South Massey Energy Company Mine ID: 46-08436:. Mine Safety and Health Administration. December 6, 2011 [in English].

2. Cybulski W. Wybuchy pylu weglowego i ich zwalczanie. Katowice, Wydaw. "Slask"., 1973.- 451 c. [in Polish].

3. Lebecki K. Zagrożenia pyĺowe w górnictwie. Katowice: Gíowny Instytut Górnictwa, 2004.- 399 c. [in Polish].

4. Agroskin, A.A. (1961). Fizicheskie svoistva uglia [Physical properties of coal]. Moscow: State NTI for ferrous and nonferrous metallurgy [in Russian].

5. Van Krevelen, D.V. (1976). Svoystva i khimicheskoie stroienie polimerov. [Properties and chemical structure of polymers]. Moscow: Khimia [in Russian].

6. Toplivo tverdoie mineralnoie. Opredelenie vykhoda letuchikh veshchestv [Solid mineral fuel. Determination of volatile substances' emission]. (2014). GOST R 55660-2013. Moscow: FGUP Standartinform [in Russian].

7. Pozharnaia opasnost veshchestv i materialov. Materialy, veshchestva, i sredstva ognezashchity. Identifikatsia metodami termicheskogo analiza [Fire hazard of substances and materials. Materials, substances, and fire protection means. Identification by thermal analysis methods]. GOST R 53293-2009 [in Russian].

8. Pozharovzryvobezopasnost goriuchikh pylei. Obshchie trebovaniia [Fire and explosion safety of combustible dusts. General requirements]. GOST 12.1.041-83 [in Russian].

9. Pozharovzryvoopasnost veshchestv i materialov. Nomenklatura pokazatelei i metody ikh opredelenia [Fire and explosion hazard of substances and materials. The nomenclature of indicators and methods for their determination]. GOST 12.1.044-89 [in Russian].

10. Lebetski, K.A., \& Romanchenko, S.B. (2012). Pylevaia vzryvoopasnost gornogo proizvodstva [Mining dust explosion hazard]. Moscow: Gornoie delo [in Russian].

11. Netsepliaev, M.I., Liubimova, A.I., \& Petrukhin, P.M. (1992). Borba so vzryvami ugolnoi pyli v shakhtakh [Combating coal dust explosions in mines]. Moscow: Nedra [in Russian].

12. Romanchenko, S.B., Gendler, S.G., Timchenko, A.N., \& Kosterenko, V.N. (2017). Eksperimentalnyie i teoreticheskie issledovania vzryvoopasnykh rudnichnykh aerozolei [Experimental and theoretical studies of explosive mine aerosols]. GIAB collection, 5-1, 181-190 [in Russian].

13. Wendlandt, W. (1978). Termicheskie metody analiza [Thermal methods of analysis]. Moscow: Mir [in Russian].

14. Gomes da Silva G. A (2008). Thermogravimetric Analysis of the Combustion of a Brazilian mineral Coal/ Quim. Nova, Issue 31, № 1,pp. 98-103 [in English].

15. Romanchenko, S.B., \& Devlikanov, M.O. (2019). Vliyaniye dispersnogo sostava ugolnoi pyli na pokazateli vzryvoopasnosti [The effect of the dispersed composition of coal dust on explosion hazard indicators]. Vestnik nauchnogo tsentra po bezopasnosti rabot v ugolnoi promyshlennosti - Herald of Safety in Mining Industry Scientific Center, 2, 16-23 [in Russian].

16. Romanchenko, S.B., \& Trubitsyn, A.A. (2019). Mikroskopicheski metod analiza stepeni uchastia pyli vo vzryvakh [Microscopic method for analyzing the degree of dust participation in explosions]. Vestnik nauchnogo tsentra po bezopasnosti rabot v ugolnoi promyshlennosti - Herald of Safety in Mining Industry Scientific Center, 3, 6-14 [in 
Russian].

17. Khludov, D.S., et al.(2014). K voprosu o metodike opredelenia uchastia ugolnoi pyli vo vzryve metanovozdushnoi smesi [To the question of the coal dust participation determining method in the explosion of a methane-air mixture]. Vestnik nauchnogo tsentra po bezopasnosti rabot v ugolnoi promyshlennosti - Herald of Safety in Mining Industry Scientific Center, 1, 150-155 [in Russian].

18. Botvenko, D.V., Goloskokov, S.I., \& Nedosekina, N.M. (2016). Metodicheskie rekomendatsii po opredeleniu stepeni uchastia ugolnoi pyli vo vzryve [Guidelines for determining the coal dust participation degree in an explosion]. Vestnik nauchnogo tsentra po bezopasnosti rabot v ugolnoi promyshlennosti - Herald of Safety in Mining Industry Scientific Center, 1, 125-130 [in Russian].

19. Romanchenko, S.B., \& Kosterenko, V.N. (2018). Polnomasshtabnyie issledovania vzryvov ugolnoi pyli i kriterii effektivnosti sredstv lokalizatsii [Full-scale studies of coal dust explosions and criteria for the containment means effectiveness].Vestnik nauchnogo tsentra po bezopasnosti rabot v ugolnoi promyshlennosti - Herald of Safety in Mining Industry Scientific Center, 4, 6-20 [in Russian].

20. Romanchenko, S.B., Rudenko, Yu.F., \& Kosterenko, V.N. Pylevaya dinamika v ugolnykh shakhtakh [Dust dynamics in coal mines]. Moscow: Gornoie delo [in Russian].

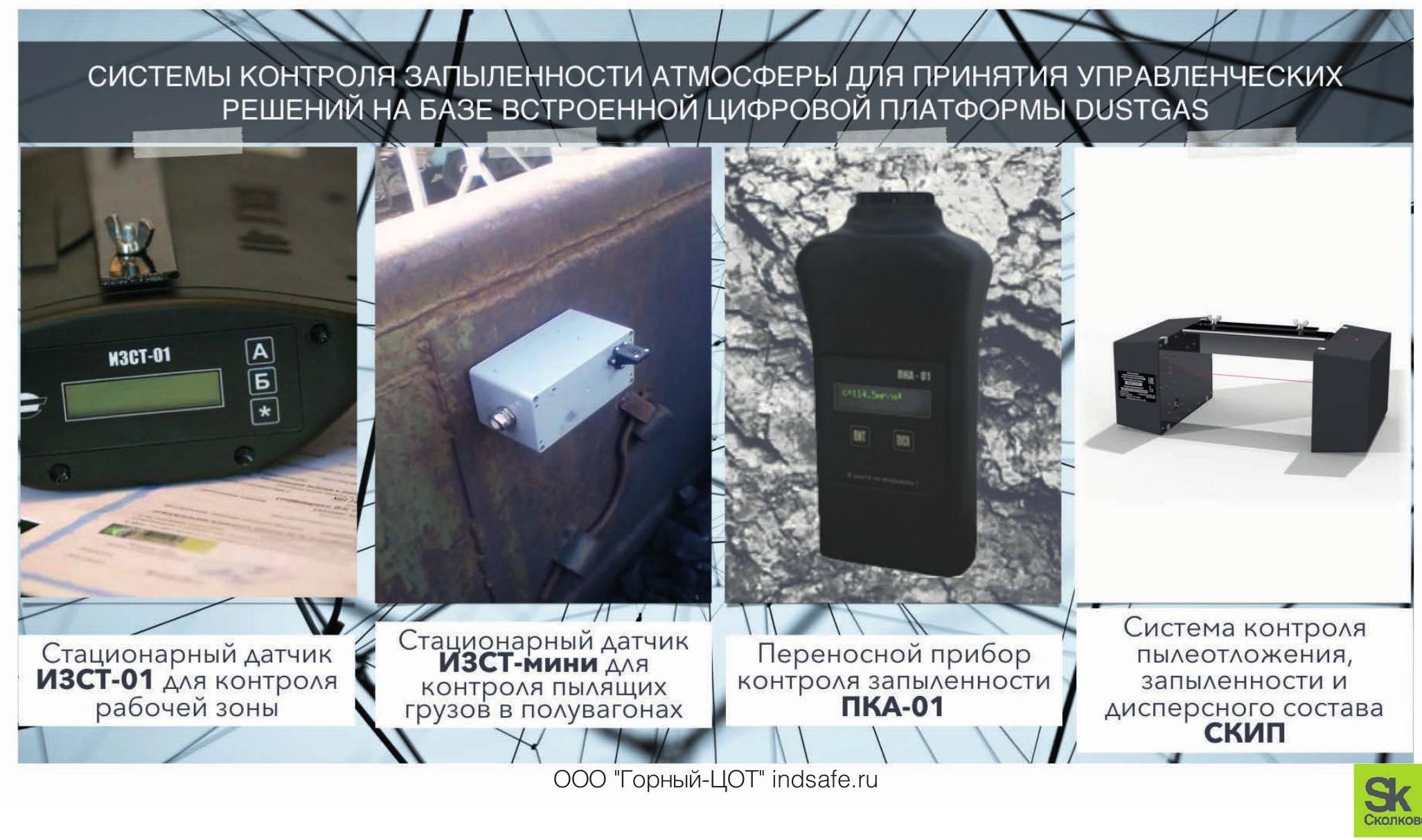




\section{І. ПРОМЫШЛЕННАЯ БЕЗОПАСНОСТЬ И ГЕОМЕХАНИКА I. INDUSTRIAL SAFETY AND GEOMECHANICS}
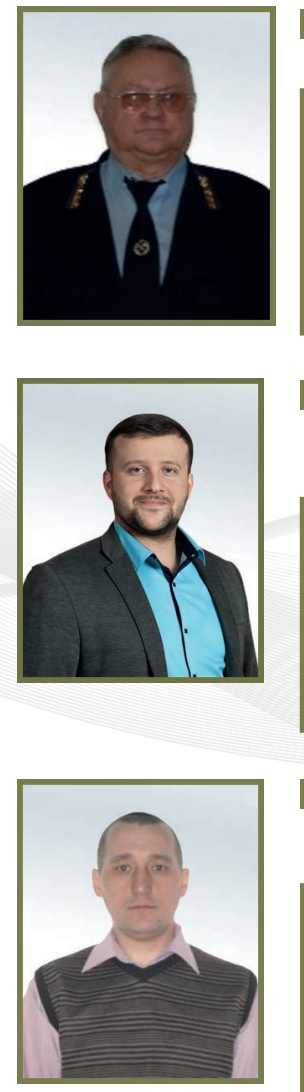

В.В. Иванов/ V.V. Ivanov v.ivanov@nc-vostnii.ru

доктор техн. наук., профессор, ведущий научный сотрудник АО «НЦ ВостНИИ»,650002, г. Кемерово, ул. Институтская, 3. АО «НЦ ВостНИИ» leading researcher of $\mathrm{AO}$ "ScC VostNII", doctor of technical sciences, professor, 650002, Kemerovo, Institutskaia St., 3 $\mathrm{AO}$ "ScC VostNII"

\section{B.B. Семенцов//}

V.V.Sementsov v.sementsov@nc-vostnii.ru

к.т.н. зав. лабораторией горной геомеханики АО «НЦ ВостНИИ», 650002 , г. Кемерово, ул. Институтская, 3. АО «НЦ ВостНИИ»

laboratory of mining geomechanics head, AO "ScC VostNII", candidate of technical sciences, 650002, Kemerovo, Institutskaia St., 3. AO "ScC VostNII"

\section{C.B. Сороковых//}

\section{S.V. Sorokovih} sorokovihslava@mail.ru

старший научный сотрудник лаборатории борьбы с

газодинамическими проявлениями $\mathrm{AO}$ «НЦ ВостНИИ», 650002, г. Кемерово, ул. Институтская, 3.

senior researcher at the Laboratory of Gas-Dynamic Symptoms Control, AO "ScC VostNII", 650002, Kemerovo, Institutskaia St., 3.

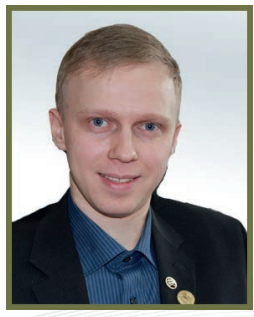

А.А. Родионов//

A.A. Rodionov

A.Rodionov@nc-vostnii.ru

научный сотрудник лаборатории

борьбы с газодинамическими проявлениями $\mathrm{AO}$ «НЦ ВостНИИ» 650002 , г. Кемерово, ул. Институтская, 3.

researcher at the Laboratory of GasDynamic Symptoms Control,AO "ScC VostNII, 650002, Kemerovo, Institutskaia St., 3.

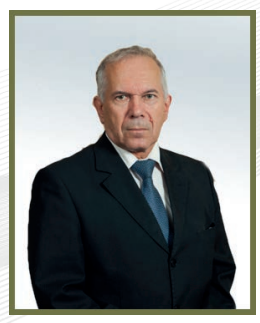

Д.Ю. Палеев//D.Yu. Paleev

доктор техн.наук, начальник научноисследовательского отдела ФГКЦ «Национальный аэромобильный спасательный учебно-тренировочный центр подготовки горноспасателей и шахтеров», 654000, г. Новокузнецк, просп. Авиаторов, 54 Head of the Research Department of the Federal State Control Center "National Airmobile Rescue Training Center for Rescuers and Miners Training", doctor of technical sciences, 654000 Novokuznezk, Avenue Aviatorov, 54

УДк 622.23:681.518.43

ПРИМЕНЕНИЕ МЕТОДА ЭЛЕКТРОТОМОГРАФИИ К ОПРЕДЕЛЕНИЮ МЕСТОПОЛОЖЕНИЯ НАРУШЕНИЙ И ВЫБРОСООПАСНЫХ ЗОН УГОЛЬНЫХ ПЛАСТОВ

\section{ELECTROTOMOGRAPHY METHOD APPLICATION TO DETERMINING THE COAL SEAMS' DISTURBED AND OUTBURST ZONES LOCATION}

В статье приводятся результаты применения метода электротомографии к определению нарушений и выбросоопасных зон угольных пластов. В качестве метода зондирования пласта использован метод диполь - дипольного электропрофилирования. При этом питающий диполь расположен в одной из подготовительных выработок, а приемный - в другой. Линия зондирования (линия, соединяющая диполи) располагалась под разными углами в плоскости пласта таким образом, чтобы получить как много больше проекций (образов Радона). Коэфффициент поглощения в фрункции двух переменных, лежащих в плоскости пласта, получен методом двумерной фильтрации. Использование метода электротомографии в условиях выбросоопасного угольного пласта показало его хорошую точность при локализации зоны нарушения пласта.

The article presents the results of applying the method of electrotomography to the determination of disturbances and outburst zones of coal seams. As a method of the seam sounding, the method of dipole - dipole electrical profiling is used. In this case, the supply dipole is located in one of the preparatory workings, and the receiving dipole is in the other. The sensing line (the line connecting the dipoles) was located at different angles in the 
plane of the seam in such a way as to obtain as many projections (Radon images). The absorption coefficient as a function of two variables lying in the plane of the seam was obtained by two-dimensional filtration method. The use of electrotomography method in the conditions of outburst dangerous coal seam showed its good accuracy in localizing the zone of seam disturbance.

КЛючевЫе слова: ЭЛЕКТРОТОМОГРАФИЯ, УГОЛЬНЫЙ ПЛАСТ, НАРУШЕНИЯ, ВЫБРОСООПАСНЫЕ ЗОНЫ, ПРОГНОЗ

Key words: ELECTROTOMOGRAPHY, COAL SEAM, DISTURBANCES, OUTBURST HAZARD ZONES, FORECAST

T

омографическая инверсия есть один из способов решения обратных задач электроразведки $[1,2]$. При исследовании внутренней структуры пласта его просвечивают излучением. Просвечивая пласт с одного направления, получают плоское (двумерное) теневое изображение трехмерного тела. Просвечивая пласт с другого направления, получают другое теневое изображение и дополнительную информацию о его внутренней структуре. Просвечивая пласт еще с одного направления, получают новую информацию и т.д. Имея большое количество проекционных снимков с различных направлений, можно с достаточной степенью точности восстановить внутреннюю структуру угольного пласта, а точнее функцию плотности поглощения излучения [3]. Внутри каждого среза плотность поглощения $\mu(x, y)$ считают функцией только двух переменных. При исследовании систему источники-приемники устраивают таким образом, чтобы регистрировать только данные на лучах, лежащих в плоскости среза (в плоскости угольного пласта).

Пусть тонкий пучок излучения (в нашем случае - тока) падает на слой вещества. Можно считать,что поглощение в конкретной точке не зависит от направления излучения.Физический закон поглощения состоит в том, что приращение интенсивности излучения (поглощение тока) $\Delta I$ пропорционально интенсивности самого излучения $I$ (тока) и длине отрезка $\Delta t$, пройденного излучением, т.е.:

$$
\Delta I=-\mu \cdot I \cdot \Delta t,
$$

где $\mu$ - коэффрициент поглощения, который зависит от точки (от вещества в окрестности точки). Мы также поставили знак минус, поскольку интенсивность излучения уменьшается, т.е. приращение интенсивности $\triangle I$ должно быть отрицательно.

Переходя к пределу $\Delta t \rightarrow 0$, получаем закон поглощения в дифференциальной фрорме:

$$
d I=-\mu \cdot I d t
$$

Параметр $\mu$ называется коэфффициентом поглощения или линейным коэфрфициентом ослабления. Он зависит от точки среды и не зависит от направления луча; его размерность $[\mu]=$
$M^{-1}$ Понятно, что при электрическом зондировании пласта коэффициент ослабления тем выше, чем меньше удельное электросопротивление угля на луче зондирования и наоборот. Выберем декартову систему координат оху с центром в геометрическом центре выемочного столба и повернутую на угол $\varphi$ вокруг начала координат систему ost. Связь между этими координатами определяется из выражений [3]

$$
\begin{aligned}
& x=s \cos j-t \sin j \\
& y=s \sin j+t \cos j
\end{aligned}
$$

Пусть зондирование осуществляется вдоль луча $s=$ const, при этом координата $t$ меняется от значения $t_{0}$ до значения $t_{k}$. Разделим переменные в уравнении (1) и проинтегрируем в этих пределах:

$$
\ln \frac{I_{0}}{I_{k}(\mathrm{~s}, \varphi)}=\int_{t_{0}}^{t_{k}} \mu(\mathrm{x}, \mathrm{y}) d t=R(\mathrm{~s}, \varphi),
$$

где $R(s, \varphi)$ считается заданной для направлений $0 \leq \varphi<\pi$, поскольку при изменении угла на $\pi$ «просвечивание» ведется в обратном направлении.

Интегрирование выполняется в области, где фрункция $\mu(x, y)$ отлична от нуля. На практике это означает, что величина $s$ ограничивается фризическими размерами объекта. Задача состоит в восстановлении функции $m(x, y)$. Правая часть выражения (3) называется преобразованием Радона (ПР), $t_{0}$ и $t_{\kappa}$ относятся к удаленным

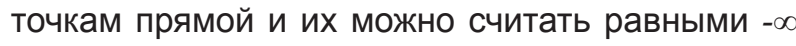
и $+\infty$. ПР определено для любой функции двух действительных переменных, которая достаточно быстро убывает на бесконечности так, чтобы соответствующие несобственные интегралы сходились. В приложениях, как правило, используются фринитные функции, которые равны нулю вне некоторой ограниченной области, так что предположение о сходимости несобственных интегралов выполняется. И.Радон [3] показал возможность восстановления функции $m(x, y)$ по ее интегралам $R(s, \varphi)$ по всем прямым и вывел формулу обращения.

Для выявления аномалий, обусловленных наличием нарушений и выбросоопасных зон угольных пластов, нами был использован способ диполь - дипольного электрозондирования пласта. При этом излучающий (питающий) диполь 


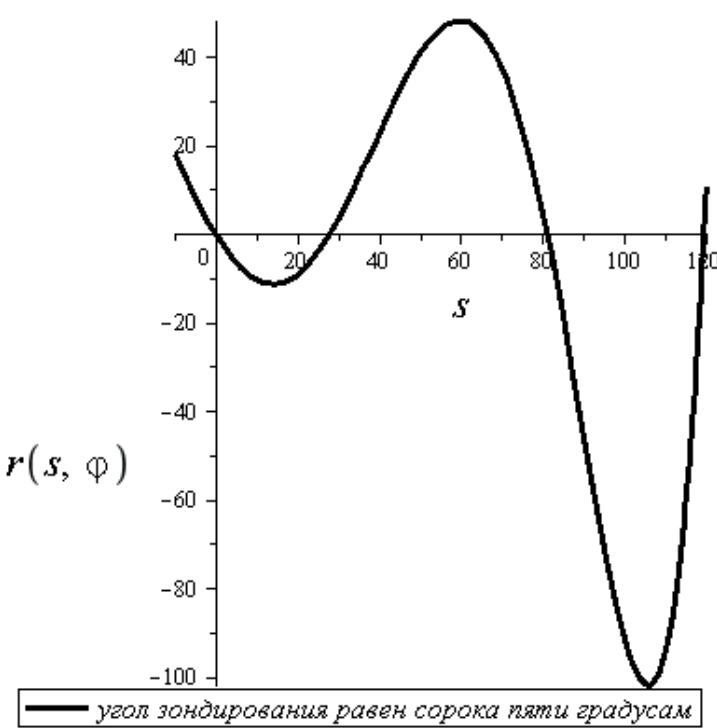

Рисунок 1 Аппроксимация образа Радона полиномом Лагранжа при электрозондировании угольного пласта

Figure 1 Approximation of the Radon image by the Lagrange polynomial in coal seam electrosounding

был расположен в одной из подготовительных выработок, оконтуривающих угольный пласт, а приемный диполь - в другой параллельной выработке. Линии зондирования пласта (линии, соединяющие питающий и приемный диполи) выбирали таким образом, чтобы получить образы Радона $r=R(s, \varphi)$ для разных значений угла $\varphi$. Аппроксимация экспериментальных значений функций $R(s, \varphi)$ для различных значений угла $\varphi$ осуществлялась с помощью полиномов Лагранжа. Выше на рис. 1 приведен образ Радона для значения угла зондирования, равного сорока пяти градусам.

При электрическом зондировании угольного пласта угол прямых зондирований (луча зондирований) с направлением выработок менялся от $7,5^{\circ}$ до $45^{\circ}$ и от $-7,5^{\circ}$ до - $45^{\circ}$. В результате был получен 21 образ Радона $r(s, \varphi)$. Затем по по-

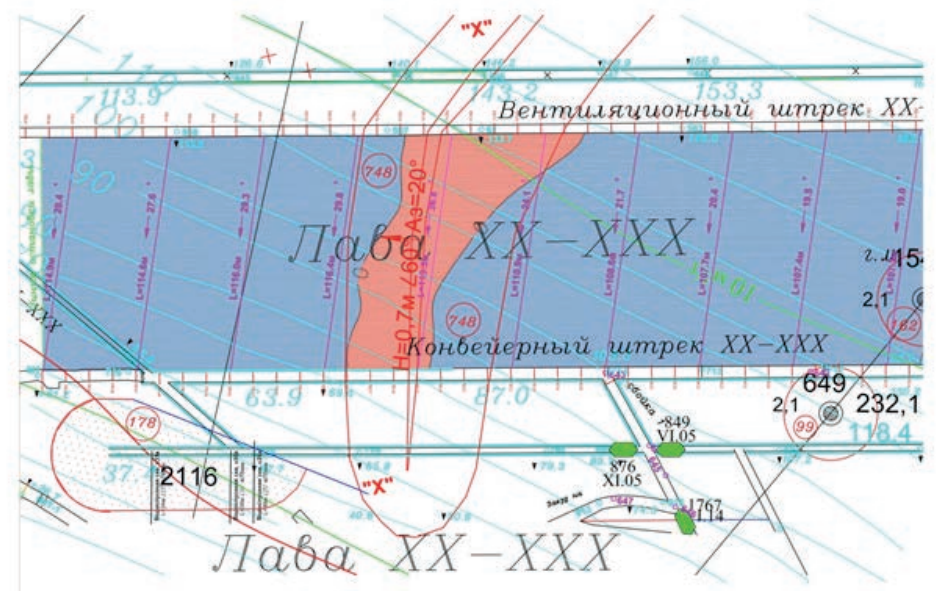

Рисунок 2 Восстановленная методом двумерной фильтрации фрункция поглощения по результатам диполь - дипольного зондирования угольного пласта

Figure 2 Absorption function reconstructed by two-dimensional filtration according to the results of dipole - dipole sounding of a coal seam

лученным образам Радона методом двумерной фрильтрации [3] восстанавливалась фуннцция поглощения $m(x, y)$.

Выше на рис. 2 приведена зона нарушения угольного пласта (выделена красным цветом), полученная по результатам электрического зондирования угольного пласта из параллельных выработок. На этом же рисунке красными линиями показаны границы зоны нарушения по данным геологической службы шахты. Как видно из этого рисунка, границы зоны нарушения с хорошей точностью обнаруживаются и по результатам электротомографиии.

Таким образом, метод электротомографии может эффрективно использоваться при решении задач по обнаружению выбросоопасных зон в угольных пластах.

\section{СПИСОК ЛИТЕРАТУРЫ}

1. Могилатов В. С., Эпов М. И. Томографический подход к интерпретации данных геоэлектромагнитных зондирований. // Изв. РАН, Сер.: Физика Земли.-1999.- N 11

2. Могилатов В. С., Эпов М. И., Исаев И. О. Томографическая инверсия данных ЗСБ-МПП. // Геология и Геофизика.- 1999. - N 4. - С.637-644.

3. Доля П. Г.Аналитические методы компьютерной томографии. Изд -во Харьковского университета, $2015 .-139$ с.

\section{REFERENCES}

1. Mogilatov, V.S., \& Epov, M.I. (1999). Tomograficheski podkhod k interpretatsii dannykh geoelektromagnitnykh zondirovani [Tomographic approach to the interpretation of geoelectromagnetic sounding data]. RAS Proseedings, Earth Physics Series, 11 [in Russian].

2. Mogilatov, V.S., Epov, M.I., \& Isaev, I.O. (1999). Tomograficheskaia inversia dannykh [Data tomographic inversion]. ZSB-MPP Geology and Geophysics, 4, 637-644 [in Russian].

3. Dolia, P.G. (2015). Analiticheskie metody kompiuternoi tomografii [Analytical methods of computed tomography]. Publishing House of Kharkov University [in Russian]. 


\section{ІІ. ПОЖАРНАЯ И ПРОМЫШЛЕННАЯ БЕЗОПАСНОСТЬ II. FIRE AND INDUSTRIAL SAFETY}
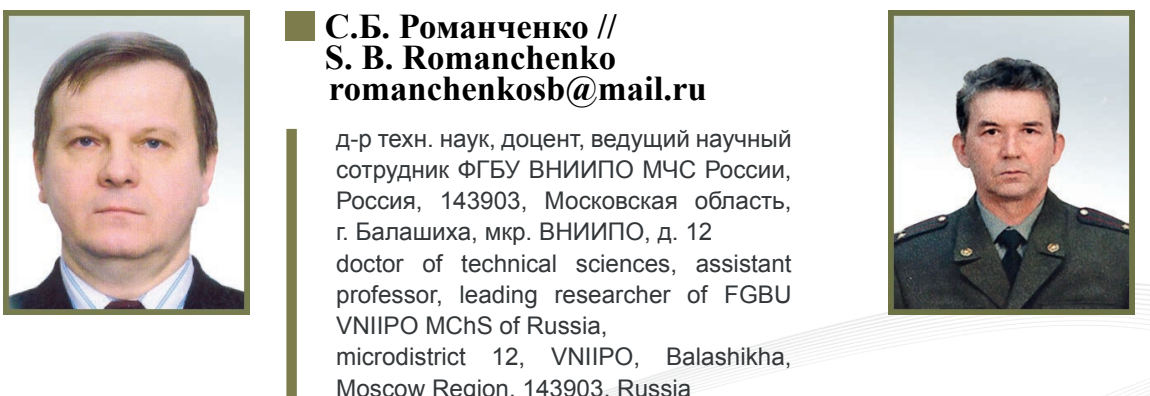

М. О. Девликанов //

M.O. Devlikanov

ведущий инженер ФГБУ ВНИиПО МЧС России

Россия, 143903, Московская область,

г. Балашиха, мкр. ВНИИПО, д. 12

leading engineer of FGBU VNIIPO MChS of Russia,

microdistrict 12, VNIIPO, Balashikha,

Moscow Region, 143903, Russia

УДК 622.81

ИССЛЕДОВАНИЕ ДИНАМИКИ ВЫХОДА ЛЕТУЧИХ

ВЕЩЕСТВ ИЗ УГОЛЬНОЙ ПЫЛИ МЕТОДАМИ

ТЕРМОГРАВИМЕТРИЧЕСКОГО АНАЛИЗА

VOLATILE SUBSTANCES EMISSION FROM COAL DUST

DYNAMICS STUDY BY METHODS OF THERMOGRAVIMETRIC ANALYSIS

В статье рассмотрены результаты термогравиметрического анализа (ТГ), выполняемые на аппаратных средствах, отличных от муфрельной печи. На термовесах исследована динамика выхода летучих веществ при термодестркуции угольного вещества при неизотермическом (с постоянным ростом температуры) методе нагрева, а также термогравиметрия по производной (ТГП). На основании действующих нормативов в области пожаро-взрывобезопасности веществ и материалов определены характерные точки термогравиметрических кривых: экстраполированные температуры начала и окончания процесса выхода летучих; температурный диапазон реакции; температура максимального выхода летучих веществ. Приведены основные показатели ТГи ТГПдля марок углей Д, ДГ, Ж. Выявлены эффректы одностадийной и двустадийной термогравиметрической реакции в процессе нагрева угля различного дисперсного состава. Проведена корреляция полученных данных с результатами аналогичных исследований зарубежных авторов.

The article discusses the thermogravimetric analysis (TG) results performed on hardware other than a muffle furnace. The dynamics of volatiles emission during thermal degradation of coal material using a non-isothermal (with a constant increase in temperature) heating method, as well as derivative thermogravimetry (TGP), was studied on a thermogravimeter. On the basis of current standards in the field of fire and explosion safety of substances and materials, the characteristic points of thermogravimetric curves are determined: extrapolated temperatures of the beginning and end of the process of volatile emission; reaction temperature range; temperature of maximum volatile substances emission. The main indicators of TG and TGP for coal grades $D, D G, Z h$. The effects of a one-stage and two-stage thermogravimetric reaction in the process of various disperse composition coal heating are revealed. The obtained data are correlated with the results of similar studies by foreign authors.

Ключевые слова: ВЗРЫВ, УГОЛЬНЫЙ АЭРОЗОЛЬ, КОНЦЕНТРАЦИЯ ПЫЛИ, ДИСПЕРСНЫЙ СОСТАВ, АЭРОЗОЛЬ, ТЕРМОГРАВИМЕТРИЯ, ВЫХОД ЛЕТУЧИХ ВЕЩЕСТВ, НИЖНИЙ КОНЦЕНТРАЦИОННЫЙ ПРЕДЕЛ ВЗРЫВАЕМОСТИ, ТЕРМИЧЕСКИЙ АНАЛИЗ, ТЕРМОДЕСТРУКЦИЯ УГЛЯ, ТЕРМОГРАВИМЕТИЧЕСКАЯ КРИВАЯ (ТГ), ТЕРМОГРАВИМЕТРИЧЕСКАЯ КРИВАЯ ПО ПРОИЗВОДНОЙ (ТГП), ДИНАМИЧЕСКАЯ ТЕРМОГРАВИМЕТРИЯ (ДТГ)

Keywords: EXPLOSION, COAL AEROSOL, DUST CONCENTRATION, DISPERSE COMPOSITION, AEROSOL, THERMOGRAVIMETRY, DEVOLATILIZATION, LOWER EXPLOSIVE CONCENTRATION LIMIT, THERMAL ANALYSIS, COAL THERMAL DEGRADATION, THERMOGRAVIMETRIC CURVE (TG), DERIVATIVE THERMOGRAVIMETRIC CURVE (TGP), DYNAMIC THERMOGRAVIMETRY (DTG) 


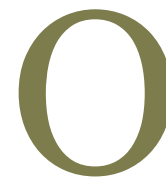

сновным показателем, посредством которого пыль относится к взрывчатой, является выход летучих веществ - $V^{\text {daf, } \% ~}{ }^{l}$, определяемый как потерю массы навески твердого топлива при нагревании в стандартных условиях [1]. При этом даже на уровне нормативов [1] отмечена сложность получения стабильных и повторяющихся данных для одной марки угля или для угля из того же пласта. Признано, что результаты испытания являются относительными, поэтому для достижения воспроизводимости необходимо соблюдать постоянство основных параметров:

-размеров зоны нагрева;

-скорости нагрева или скорости восстановления температуры в печи после помещения в неё образцов;

-температуры нагрева образцов $(900 \pm 5)^{\circ} \mathrm{C}$; (7 минут).

-суммарной продолжительности нагрева

Единственной аппаратурой, предусмотренной действующим ГОСТ Р 55660-2013 является муфельная печь с электронагревом и терморегулятором (рисунок 1) .

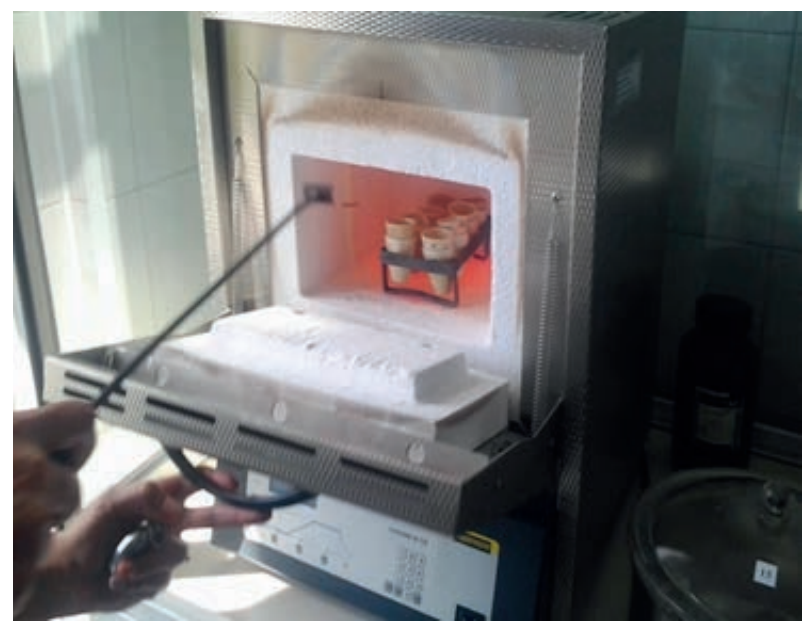

Рисунок 1 - Определение выхода летучих из угольной пыли в муфрельной печи

Figure 1 - Devolatilization determination from coal dust in a muffle furnace

Тепловая мощность муфельной печи (рисунок 1) должна быть такой, чтобы после внесения в печь холодной подставки с тиглями величина переходного температурного периода $\left(t_{s}\right)$, во время которого температура в зоне нагрева восстанавливалась до требуемых $900^{\circ} \mathrm{C}$, была не более чем 4 минуты $\left(t_{s} \leq 4\right.$ мин). Процесс переходного теплового режима или режима восстановления температуры в печи определенно влияет на точность определения $V^{d a f}$ : различная пересчете на сухую беззольную массу - Dry Ash Free. конструкция дверцы (скорость закрывания или размеры дверцы, определяющие вынос тепла) в сочетании с различной тепловой мощностью нагревательного элемента определяют разницу суммарного режима нагрева.

Вторым фактором, ограничивающим информативность данных, полученных в муфельных печах, является возможность получения на выходе только одного показателя - величину потери массы образца, выраженную в процентах - $V^{d a f}$. Исследование динамики процесса в муфрельной печи невозможно.

Указанные выше проблемные вопросы решаются применением термогравиметрии (ТГ) - метода термического анализа, при котором проводится изменение массы образца с шагом времени (как правило - через 1с) и строится зависимость массы образца, как функция времени $M=F(t$, сек) или функция от температуры $M=$ $f\left(T,{ }^{\circ} C\right)$. Методы ТГ не исключают изотермического режима нагрева с постоянной температурой - аналога нагреву в муфельной печи. Отличие
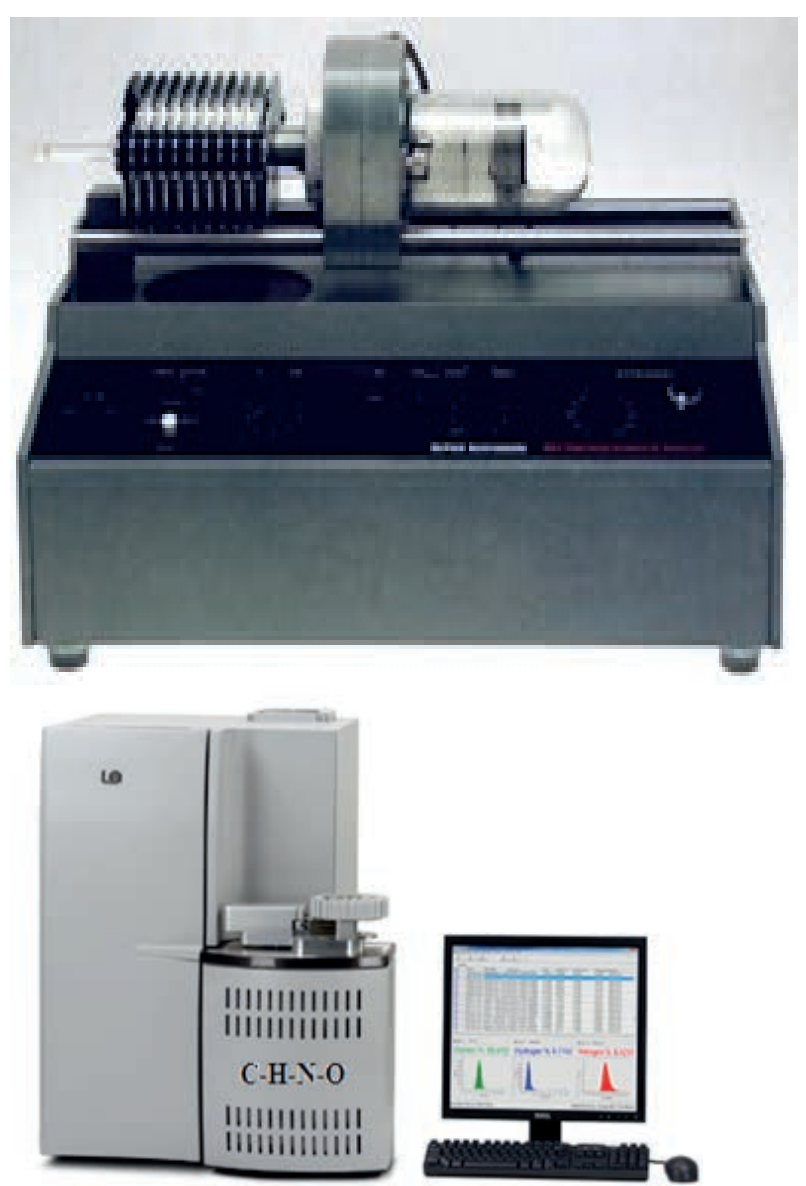

Рисунок 2 - Оборудование для термогравиметрического и газового анализа (вверху - для исследования 1 образца, внизу - до 16 образцов одновременно с распознаванием газов) Figure 2 - Equipment for thermogravimetric and gas analysis (on the left - to study 1 sample, on the right - up to 16 samples simultaneously with gas recognition) 


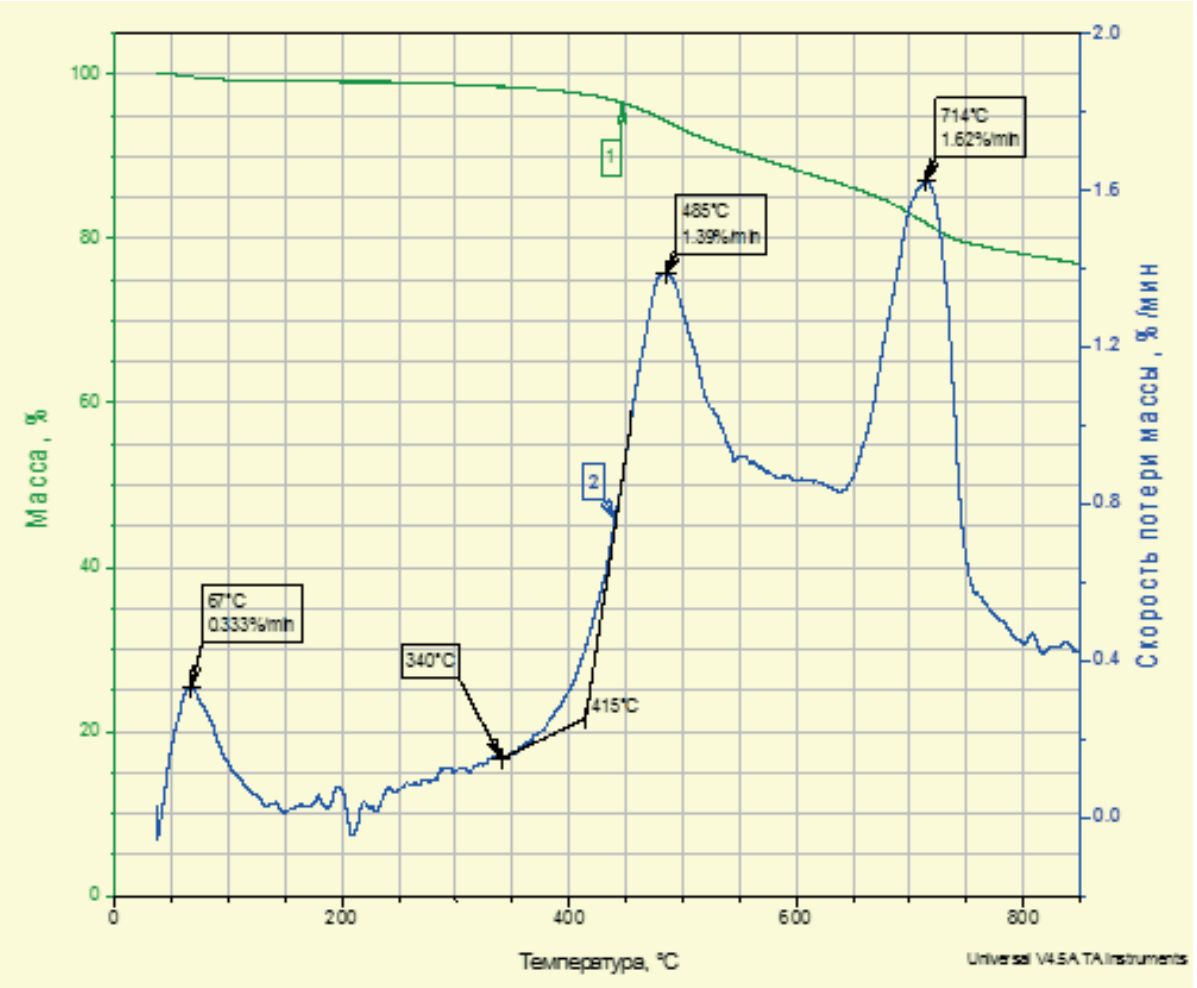

Рисунок 3 - Характерные ТГ и ТГП кривые угля марки «Г» (1 - ТГ-кривая; 2 - ДТГ-кривая), режим нагрева - с постоянным ростом температуры 20

Figure 3 - Typical TG and TGP curves of "G" grade coal (1 - TG curve; 2 - DTG curve), heating mode - with a constant increase in temperature 20

состоит в пошаговой регистрации массы образца и построении функциональной зависимости $M=F(t, c e \kappa)[2,3,4]$.

Используемая для ТГ аппаратура - термогравиметрические весы различной конструкции с возможностями термического анализа образцов пыли или с дополнительными функциями газового анализа выделяющихся летучих (рисунок 2).

При исследовании свойств углей выделяют два основных вида ТГ [5]:

- изотермическая или статическая - масса образца измеряется на протяжении некоторого времени при постоянной температуре (аналог нагрева в муфельной печи). При изотермических исследованиях выхода летучих из углей в термогравиметрических весах применяется температура $900^{\circ} \mathrm{C}$. Возможности современной аппаратуры позволяют достаточно быстро восстанавливать (или устанавливать) требуемую температуру за время менее 1 минуты $\left(t_{\theta} \approx 1\right.$ мин или $t_{s}<<4$ мин), на основании измерений массы через 1 секунду строится зависимость выхода летучих веществ во времени $M=F(t$, сек);

- динамическая - температура среды изменяется по заданному закону (обычно с постоянной скоростью). В этом случае возможно получение обеих указанных функций $M=F(t, c e \kappa)$ и $M$
$=f\left(T,{ }^{\circ} \mathrm{C}\right)$, а также их производных (ТГП).

При исследовании процессов выхода летучих веществ из угольной пыли [6,7] в ФГБУ ВНИИПО МЧС России наряду со статической использована динамическая ТГ, как наиболее информативный метод ${ }^{2}$. Исследуемый образец нагревался от начальной температуры $20^{\circ} \mathrm{C}$ до $900^{\circ} \mathrm{C}$ с заданной скоростью роста температуры $20^{\circ} \mathrm{C} /$ мин. В этом случае исследована интенсивность выхода летучих веществ при различных температурах нагрева. Получаемая зависимость $M=f\left(T,{ }^{\circ} \mathrm{C}\right)$ приведена на рисунке 3 (кривая 1).

Необходимо отметить, что в динамической ТГ температура образца является фонкцией времени [5]:

$$
T=\varphi(t)=T_{0}+A \cdot t
$$

где $T$ - температура; $A$ - скорость нагрева град/ мин.; $t$ - время.

Поэтому изменение массы образца более информативно представляется с размещением времени процесса по оси абсцисс, а температура откладывается на правой дополнительной шкале. В этом случае обе зависимости $M=F(t$, сек) и $T=\varphi(t, c е \kappa)$ изображаются как-бы одновременно и принимают вид, представленный на рисунке 4 (кривая 1 и кривая 3).

Полученные термогравиметрические кривые (кривая 1 на рисунках 3 и 4) позволяют 


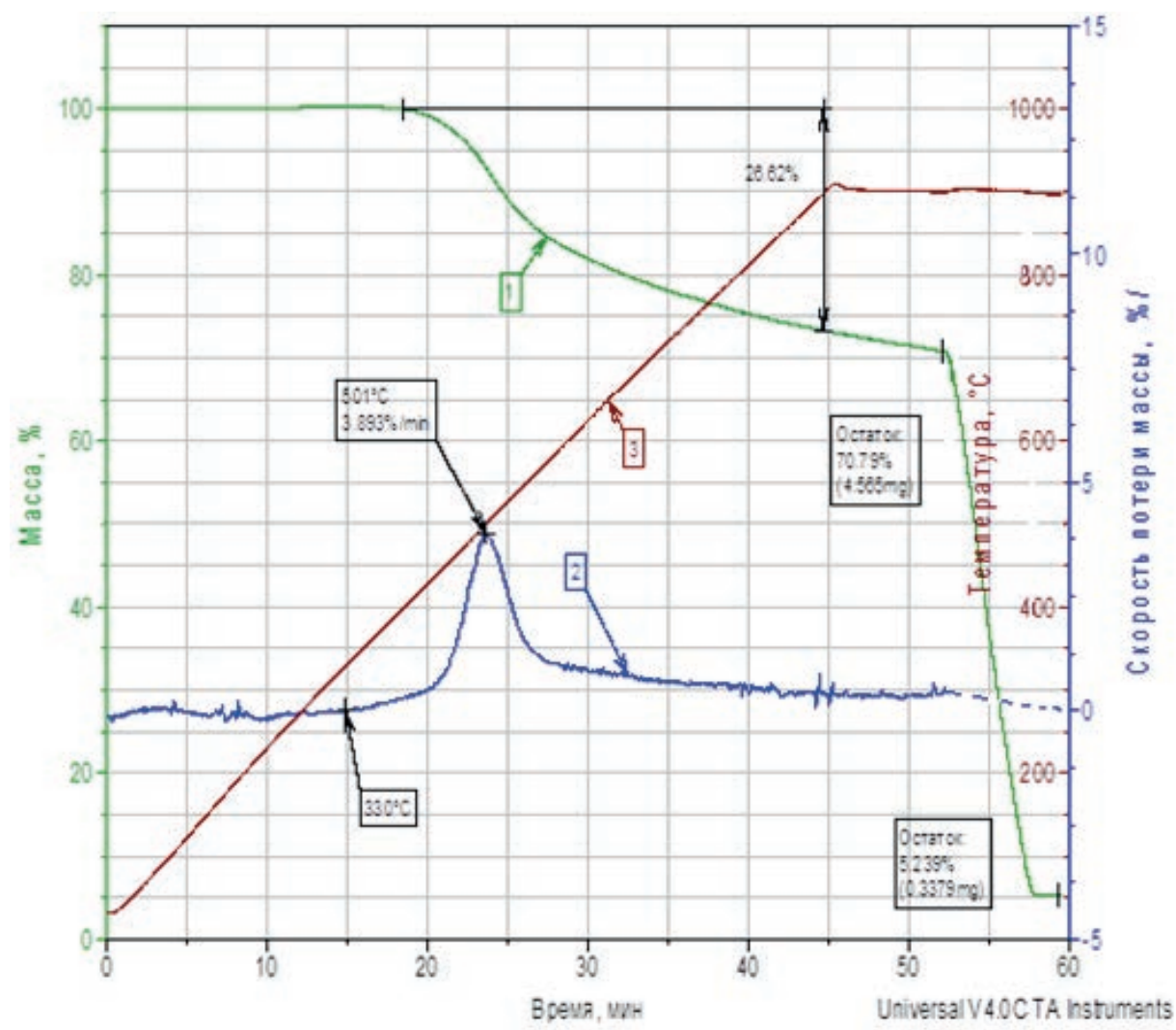

Рисунок 4 - Результаты совмещенного ТГ и ДТГ анализа угля марки «Ж» Figure 4 - The results of combined TG and DTG analysis of coal grade "Zh"

определить характерные точки процесса, судить о массе образца в начальном состоянии - $M_{0}$, массе остатка (золы) $M_{3}$, а также о степени термостабильности образца.

Кроме изменения непосредственно массы образца, практический интерес представляет получение данных об интервале температур процесса выхода летучих и о температуре, при которой процесс выхода летучих веществ имеет максимальную интенсивность. Данная информация получена при помощи построения производной от массы по времени $(d m / d t)$ (кривая термогравиметрии по производной - ТПГ)

$$
d m / d t=f(T)
$$

Кривые ТГП для углей марки «Г» и «Ж» представлены соответственно на рисунках 3 и 4 (кривая 2).

Метод термогравиметрии по производной, предложенный ДеКейзером ${ }^{3}$, в последующем широко применялся значительным числом исследователей $[5,6,8]$.

Как видно из рисунка 4, для одностадийной неизотермической реакции существуют характерные точки на ТГ и ТГП-кривой:

а) начальная температура разложения $T_{i}-$ температура, при которой суммарное изменение массы превышает чувствительность весов (ри- сунок 4 , точка $330^{\circ} \mathrm{C}$ ). Одновременно с $T_{i}$ нормативно [2] определена экстраполированная точка начала процесса - точка пересечения касательной, проведенной в точке наибольшего наклона с экстраполированной базовой линией (рисунок 3, точка $\left.415^{\circ} \mathrm{C}\right)$;

б) конечная температура - $T_{f}$, при которой суммарное изменение массы достигает максимального значения, что соответствует завершению реакции, и соответствующая ей экстраполированная точка окончания процесса. Величина $T_{f}-T_{i}$ называется интервалом реакции;

в) температура максимального выхода летучих веществ (рисунок 4, кривая 2 , точка $501^{\circ} \mathrm{C}$ ).

На основании исследований определено, что для определенных проб угля реакция термодеструкции не является одностадийной (рисунок 3, кривая 2). Имеются две явно выделенные стадии выхода летучих веществ: первичная (условно соответствует первичному этапу горения угольной пыли) - выделение летучих при разрушении боковых групп макромолекул угля, отличающихся низкой термической устойчивостью, а также вторичная - выделение летучих за счет деструкции ядра макромолекулы угля (условно соответствует второй стадии горения угля, когда происходит непосредственное окисление угле- 


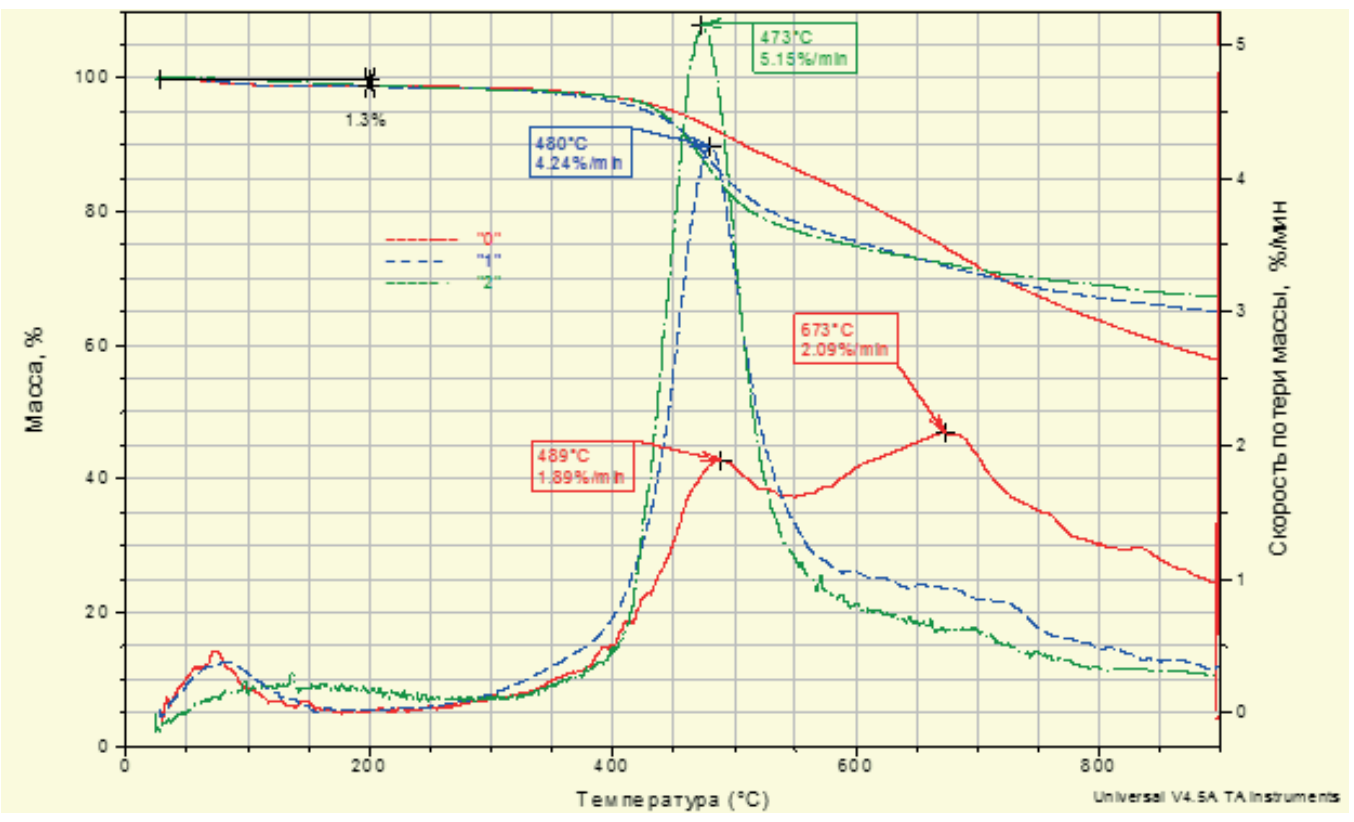

Рисунок 5 - Характерные ТГ (верхняя группа кривых) и ТГП кривые для 3-х образцов пыли угля марки «ДГ»

Figure 5 - Typical TG (upper group of curves) and TGP curves for 3 samples of DG grade coal dust

рода). Для двустадийных реакций ТГП кривая позволяет выделить интервал для обеих стадий и соответственно получить 6 характерных точек ТГП кривой (рисунок 3).

Для энергетического угля по результатам ТГ исследований (рисунок 3, рисунок 5) определены следующие характерные точки процесса:

- удаление остаточной влаги из угольной пыли (0,71 - 0,83\%) происходит при температуре $95-110^{\circ} \mathrm{C}$;

- экстраполированная (по ГОСТ 532932009) температура начала интенсивного выделения летучих для энергетических марок углей составляет около $415^{\circ} \mathrm{C}$

- максимальный выход летучих (первая стадия) незначительно корректируется дисперсностью пыли (1,5-2\%) и находится в пределах $480-485^{\circ} \mathrm{C}$ (угли «Г» и «ДГ»)

- для пылей с высокой степенью дисперсности частиц выявлены две стадии термодеструкции с максимумами скорости процесса при температурах 489 и $673^{\circ} \mathrm{C}$ (уголь ДГ, рисунок 3) и 485 и $714^{\circ} \mathrm{C}$ (уголь Г).

Аналогичные данные для угля марки «Ж» (коксующийся уголь, Печерский угольный бассейн) приведены на рисунке 4. Представленный образец сухого чистого угля отличался низкой влажностью (менее 0,5 \%), зольность после дожигания в кислородной среде составила около $5 \%$. Максимальная скорость выхода летучих веществ наблюдалась при температуре $501^{\circ} \mathrm{C}$ (3,89\%/мин). Экстраполированная температура начала выделения летучих $425^{\circ} \mathrm{C}$. Диапазон реакции интенсивного выхода летучих веществ
425-575 ${ }^{\circ} \mathrm{C}$. Атмосфера нагрева - азот.

В ходе термогравиметрических исследований подтверждена существенная роль дисперсного состава пыли на процесс термической деструкции угля или на процессы выхода летучих веществ. На рисунке 5 представлены ТГ и ТГП кривые для одного и того же образца угля марки ДГ, отличающиеся степенью дисперсности (образцы «0», «1» и «2» - в порядке роста макимального размера частиц и моды эквивалентного диаметра).

Как видно из рисунка 5, на процесс выхода летучих веществ дисперсный состав влияет относительно слабо для частиц угля с величиной частиц 50-60 мкм и более (кривые 1 и 2 практически совпадают), однако для тонких фракций пыли ситуация изменяется принципиально. Вместо одностадийного процесса термодеструкции (кривые 1 и 2, рисунок 5) для тонких фрракций пыли (кривая «0») выход летучих имеет явно выделенные две стадии с локальными максимумами кривой ТГП в районе $489^{\circ} \mathrm{C}$ и в районе $673^{\circ} \mathrm{C}$ - вторичное выделение летучих, связанное с разрушением термоустойчивого ядра макромолекул угля.

Полученные зависимости (с учетом разницы в свойствах исследованных образцов угля) достаточно хорошо коррелируются с данными зарубежных исследователей, среди публикаций последнего периода возможно выделить работы $[8,9,10]$. Зарубежная классификация каменного угля, широко используемая в реакторной технике, связана с теплотой сгорания угля, в которой угли называются в соответствии с возрастающей 


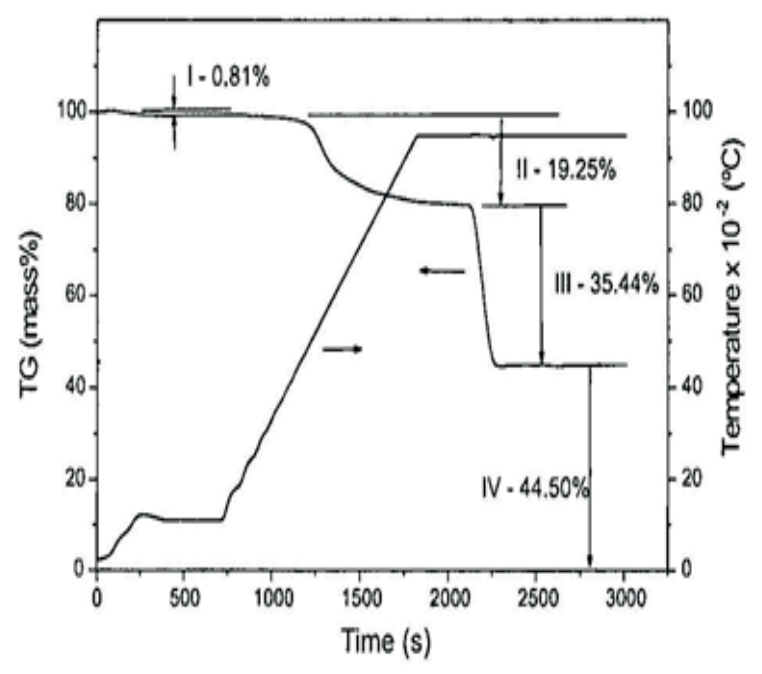

Рисунок 6 - Стадии термогравиметрического процесса при анализе угля [8]

Figure 6 - Stages of the thermogravimetric process in the analysis of coal [8]

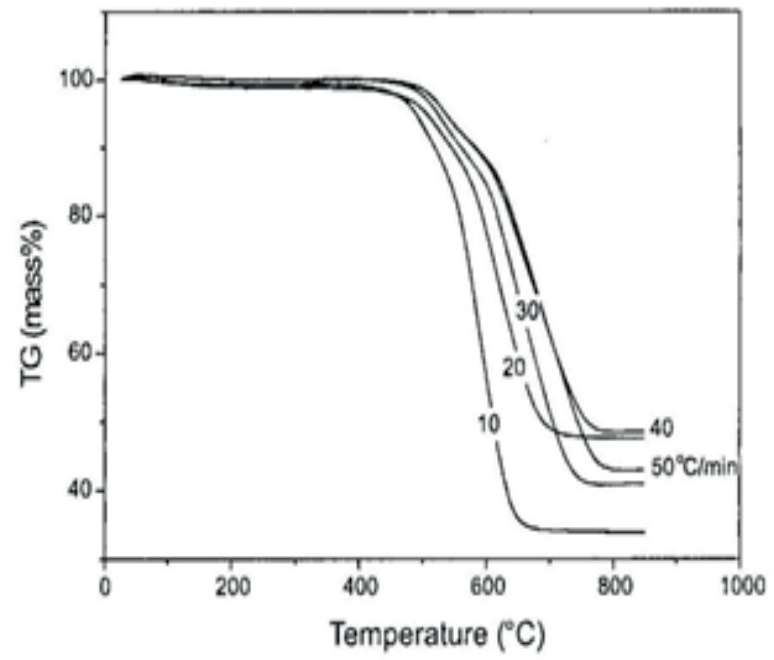

Рисунок 8 - Влияние скорости нагрева образцов на выход летучих веществ [8]

Figure 8 - The influence of the heating rate of samples on the volatile substances emission [8]

теплотой сгорания: лигниты, полубитуминозные, битуминозные, полубитумные, полуантрациты и антрациты.

Зарубежные исследователи $[8,9,10]$ подразделяют возгорание угольных частиц на гомогенное (летучие вещества) и гетерогенное (твердое вещество - поверхность). Креллинг [10] и другие авторы рассмотрели два основных реактивных события, происходящих во время сжигания угля, называемых первичным и вторичным горением. Первый тип сгорания учитывает комбинированное удаление летучих компонентов и одновременное частичное горение связанного углерода, в то время как второй тип учитывает последующее горение исключительно связанного углерода.

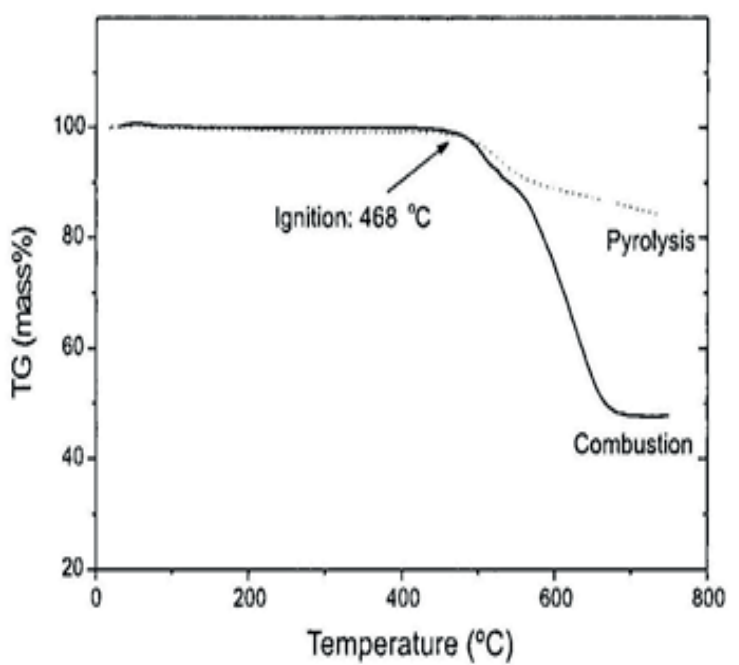

Рисунок 7 - Результаты ТГ пиролиза и горения угля, используемые для определения температуры возгорания [8]

Figure 7 - The results of TG pyrolysis and coal combustion used to determine the ignition temperature [8]

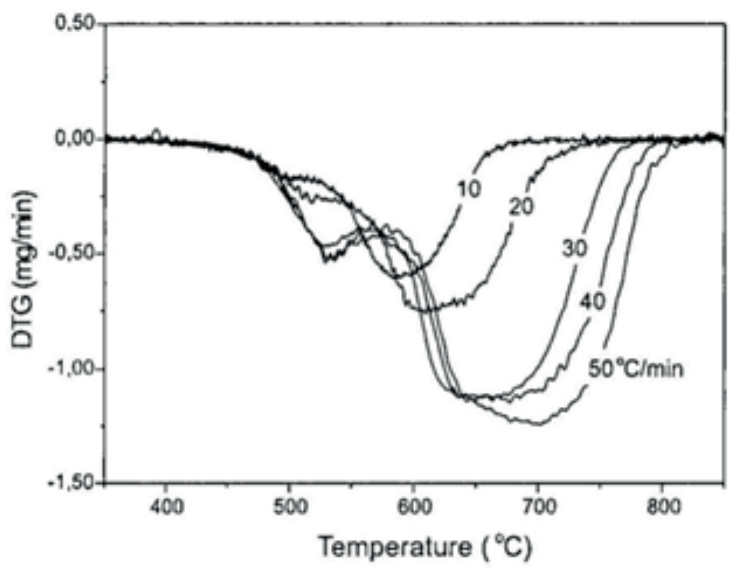

Рисунок 9 - Кривые ДТГ для скоростей нарастания температуры $10-50^{\circ} \mathrm{C} / \mathrm{Muн[8]}$

Figure 9 - DTG curves for temperature rise rates of 10-50 ${ }^{\circ} \mathrm{C} / \min [8]$

В работе [8] было использовано несколько скоростей нагрева для оценки их воздействия на кинетику. В ТГ экспериментах были применены скорости нагрева от 10 до $50^{\circ} \mathrm{C} /$ мин. В экспериментах была применена инертная атмосфрера $\mathrm{N}_{2}$, с сохранением $110^{\circ} \mathrm{C}$ изотермы до тех пор, пока не был завершен процесс высушивания. Затем возобновлялся нагрев, и температура $950^{\circ} \mathrm{C}$ поддерживалась постоянной до завершения процесса пиролиза. Кроме этого, в экспериментах со сжиганием были использованы воздушная атмосфера, также с сохранением $110^{\circ} \mathrm{C}$ изотермы до завершения стадии высушивания. Затем продолжался процесс нагрева до $850^{\circ} \mathrm{C}$ и изотерма сохранялась до конца сгорания твердого углерода. 
Таблица 1 Экспериментальное определение температуры различных стадий выхода летучих веществ из угля (сопоставление исследований в различных научных центрах)

Table 1 Experimental determination of coal volatile substances emission various stages temperature (comparison of studies in various research centers)

\begin{tabular}{|l|c|c|}
\hline \multirow{2}{*}{ Марка угля } & \multicolumn{2}{|l|}{$\begin{array}{l}\text { Температура максимального выхода летучих веществ (скорости } \\
\text { потери массы образца), }{ }^{\circ} \text { С на стадиях: }\end{array}$} \\
\cline { 2 - 3 } & «Первичное горение» & «Вторичное горение» \\
\hline Битумиозный $[8]$ & 503 & 610 \\
\hline «Г», (Кузбасс) & 485 & 714 \\
\hline «ДГ», (Кузбасс) & 489 & 673 \\
\hline
\end{tabular}

На рисунке 6 представлен типовый результат [8] термогравиметрического анализа в инертной среде $\left(N_{2}\right)$ с выделением стадий процесса: I - удаление влаги; II - выход летучих веществ; III - связанный углерод; IV - зола.

На рисунке 7 представлены результаты ТГ по пиролизу (нагреву в инертной среде) и горению угля (нагрев в атмосфере с присутствием кислорода), которые демонстрируют возможность использования методов ТГ для определения температуры возгорания угля. Предполагается, что температура возгорания является средней температурой в последнем временном интервале, где обе кривые совпадают [10].

Рисунок 8 представляет результаты ТГ экспериментов с различной скоростью нагрева, которые наглядно демонстрируют наличие зависимости величины выхода летучих веществ из исследуемого образца от скорости нарастания температуры в месте нагрева.

На рисунке 9 представлены кривые дифференциальной термической гравиметрии [8] (ТГП или принятое за рубежом обозначение ДТГ - динамическая термогравиметрия), полученные путем дифрференцирования по времени ТГкривых из рисунка 8.

По полученным в [8] результатам выделены два основных реактивных явления, которые определены как «первичное горение» (пик в районе $500^{\circ} \mathrm{C}$ ) и «вторичное горение» (пик в районе 639-700С). Результаты исследований, проведенных ФГБУ ВНИИПО (рисунок 3, рисунок 5), соответствуют кривой «20» или $20^{\circ} \mathrm{C}$ /мин на рисунке 9. Результаты исследований в различных научных центрах сопоставимы (таблица 1):

Выводы по проведенным исследованиям:

1. При нагреве угля в инертной среде исключаются вторичные окислительные реакции, связанные с соединением с кислородом выделенных из угля летучих веществ.

2. Экстраполированная температура начала интенсивного выхода летучих веществ для энергетических марок углей составляет $415^{\circ} \mathrm{C}$.

3. Температура максимального выхода летучих (первая стадия) находится в пределах $485-489^{\circ} \mathrm{C}$ (угли «Г» и «ДГ»)

4. С увеличением стадии метаморфизма угля от «Г» до «Ж» температура начала интенсивного выхода летучих возрастает незначительно с $410^{\circ} \mathrm{C}$ до $425^{\circ} \mathrm{C}$, а также возрастает температура максимального выхода летучих с $480-485^{\circ} \mathrm{C}$ (энергетические марки углей) до 500$510^{\circ} \mathrm{C}$ (коксующиеся угли).

5. Для пылей энергетических углей (по аналогии с зарубежными исследованиями «битумиозного» угля) выявлены две стадии термодеструкции с максимумами скорости процесса при температурах соответственно $489^{\circ} \mathrm{C}$ и $673^{\circ} \mathrm{C}$ (уголь ДГ, рисунок 5) и $485^{\circ} \mathrm{C}$ и $714^{\circ} \mathrm{C}$ (уголь Г).

\section{СПИСОК ЛИТЕРАТУРЫ}

1. Национальный стандарт РФ ГОСТ Р 55660-2013 Топливо твердое минеральное. Определение выхода летучих веществ. - М.: ФГУП «Стандартинформ».-2014.-17 с.

2. ГОСТ Р 53293-2009. Пожарная опасность веществ и материалов. Материалы, вещества, и средства огнезащиты. Идентификация методами термического анализа.

3. ГОСТ 12.1.041-83.Пожаровзрывобезопасность горючих пылей. Общие требования.

4. ГОСТ 12.1.044-89. Пожаровзрывоопасность веществ и материалов. Номенклатура показателей и методы их определения.

5. Уэндландт У. Термические методы анализа. - М.: Мир, 1978. - 526с.

6. Романченко С.Б., Шентяпин Д.С., Чистяков А.В., Буторин С.Н. Экспериментальные исследования показателей 
взрывчатости угольной пыли. Пожарная безопасность -2016. №3.-С.156-162.

7. Романченко С.Б. Экспериментальные и теоретические исследования взрывоопасных рудничных аэрозолей/ Романченко С.Б., Гендлер С.Г., Тимченко А.Н., Костеренко В.Н.// В сб. ГИАБ, специальный выпуск №5-1, 2017. c181-190

8. Gomes da Silva G. A Thermogravimetric Analysis of the Combustion of a Brazilian mineral Coal/ Quim. Nova, Bып. 31, № 1, c. 98-103, 2008.

9. Davini P., Ghetti P., Bonfanti, L.; De Michele, G.; Fuel 1996, 75, 1088

10. Crelling J. C.; Fuel 1992, 71, 158.

\section{REFERENCES}

1. Toplivo tverdoie mineralnoie. Opredelenie vykhoda letuchikh veshchestv [Solid mineral fuel. Determination of volatile substance emission]. (2014). Gost R 55660-2013. Moscow: FGUP Standartinform [in Russian]

2. Pozharnaia opasnost veshchestv i materialov. Materialy, veshchestva, i sredstva ognezashchity. Identifikatsia metodami termicheskogo analiza [Fire hazard of substances and materials. Materials, substances, and fire protection means. Identification by thermal analysis methods]. GOST R 53293-2009 [in Russian].

3. Pozharovzryvobezopasnost goriuchikh pylei. Obshchie trebovania [Fire and explosion safety of combustible dusts. General requirements]. GOST 12.1.041-83 [in Russian].

4. Pozharovzryvoopasnost veshchestv i materialov. Nomenklatura pokazatelei i metody ikh opredelenia [Fire and explosion hazard of substances and materials. The nomenclature of indicators and methods for their determination]. GOST 12.1.044-89 [in Russian].

5. Wendlandt, W. (1978). Termicheskie metody analiza [Thermal methods of analysis]. Moscow: Mir [in Russian].

6. Romanchenko, S.B., Shentiapin, D.S., Chistiakov, A.V. \& Butorin, S.N. (2016). Eksperimentalnye issledovania pokazatelei vzryvchatosti ugolnoy pyli [Experimental studies of coal dust explosiveness indicators]. Pozharnaya bezopasnost-Fire safety, 3, 156-162 [in Russian].

7. Romanchenko, S.B., Gendler, S.G., Timchenko, A.N., \& Kosterenko, V.N. (2017). Eksperimentalnyie i teoreticheskie issledovania vzryvoopasnykh rudnichnykh aerozolei [Experimental and theoretical studies of explosive mine aerosols]. GIAB collection, 5-1, 181-190 [in Russian]

8. Gomes da Silva G. A Thermogravimetric Analysis of the Combustion of a Brazilian mineral Coal/ Quim. Nova, Issue 31, № 1, pp. 98-103 [in English].

9. Davini P., Ghetti P., Bonfanti, L., De Michele, G. (1996). Fuel

10. Crelling J. C. (1992). Fuel

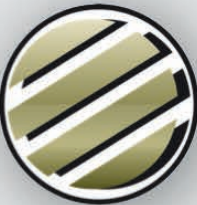

\section{СИСТЕМЫ}

ПНЕВМОГИДРООРОШЕНИЯ ДЛЯ БОРЬБЫ С ПЫЛЬЮ (ПГО)

созАаёт водовозАушный туман от 3,5 мкм, который поглощает угольную, породную, руАную, органическую и другие виды пыли и препятствует её Аа^ьнейшему распространению

- Снижение расхода воды до 12 раз, рабочее давление 5 атм, расход воды от 0,5 ^/мин на 1 форсунку

- Может использоваться со спец Аобавкой Аля работы при отрицательных температурах

- Снижение запыленности на $80 \%$

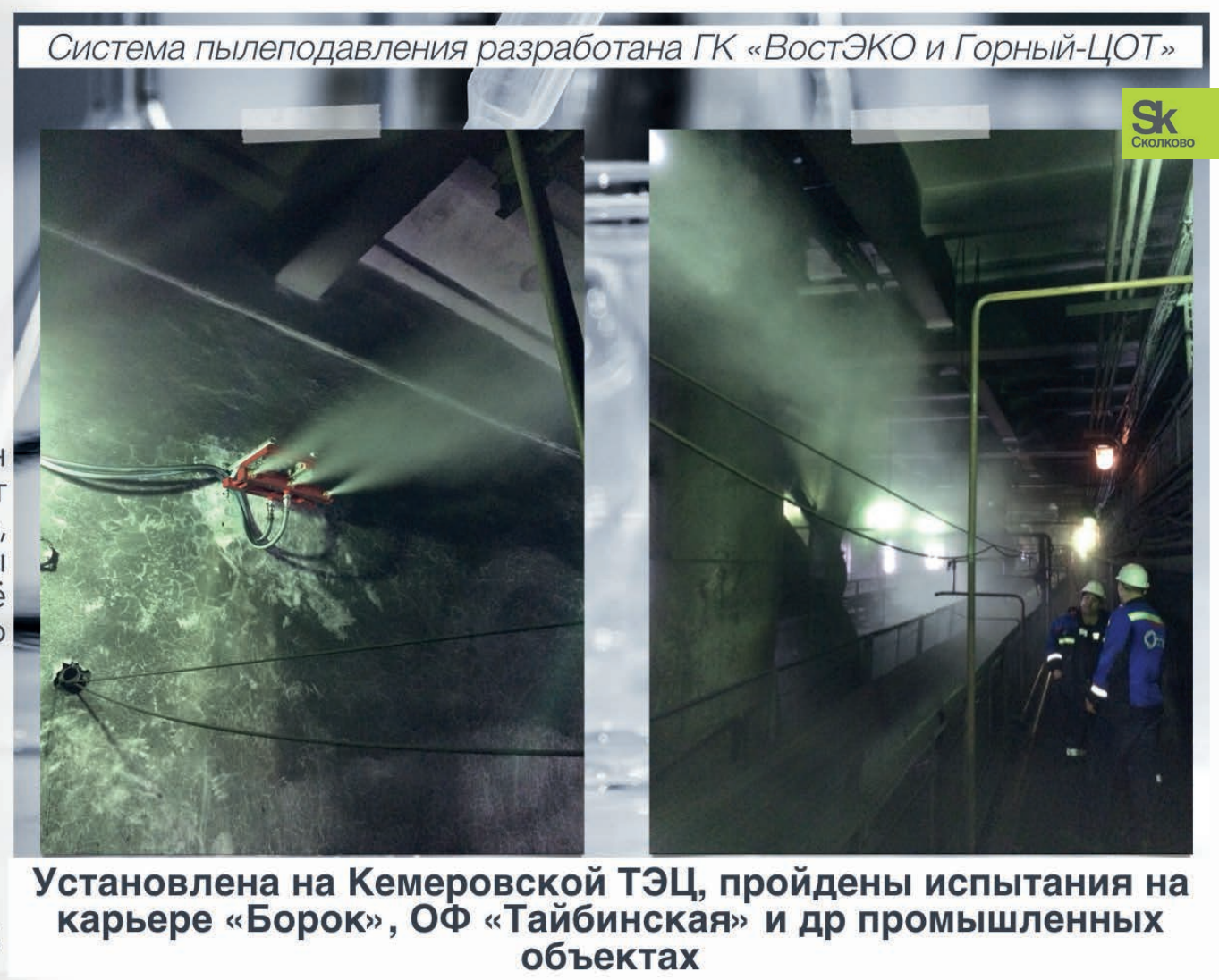

indsafe.ru 


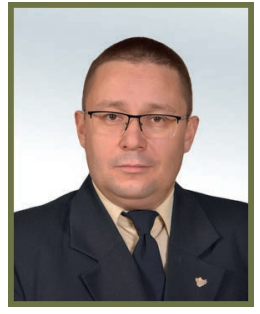

А.В. Угольников //

A. V. Ugolnikov

ugolnikov@yandex.ru

кандидат технических наук, доцент,

заведующий кафедрой электротехники

Уральский государственный горный

университет

620144, Россия, г. Екатеринбург, ул.

Куйбышева, 30

УДК 622.8

\section{КРИТЕРИАЛЬНОЕ УРАВНЕНИЕ ГИДРОВИХРЕВОЙ КОАГУЛЯЦИИ ВЗРЫВООПАСНЫХ АЭРОЗОЛЕЙ CRITERIA EQUATION FOR HYDRO-VORTEX COAGULATION OF EXPLOSIVE AEROSOLS}

В статье изложен анализ основных фракторов негативных техногенных процессов на угольных шахтах, несовершенства технологии локализации взрывов угольной пыли, ограничивающих дальнейшее повышение эфрфективности добычи и глубокой переработки минерального сырья. В развитие математической модели гидровихревой коагуляции показана определяющая роль дисперсии завихренности в разрушении абсорбционной оболочки капли жидкости в зоне контакта с частицей пыли. Получено диффференциальное уравнение движения частии пыли с учетом влияния дисперсии завихренности, доказана его гомогенность с уравнением плоского движения вязкой несжимаемой жидкости, определены независимые параметры вихревой инерционной ортокинетической гетерокоагуляции. Определены критерии подобия, построены критериальные уравнения циркуляционного пылеподавления на базе модифицированной математической модели вихревого кинематического взаимодействия в системе «жидкое-твердое». Доказана определяющая роль критерия Стокса и возможность снижения его критических значений в процессе гидровихревого поглощения частии пыли. Показано существенное снижение потребной энергии полного поглощения частиц пыли, вращающимися каплями жидкости, расхода воды и медиального диаметра поглощаемой пыли по сравнению с классическим гидрообеспыливанием, что повышает эффрективность локализации взрыва мелкодисперсных пылевых аэрозолей. Предложена конструкция гидровихревой фрорсунки, устройства локализации взрывов пылевых смесей.

The article presents an analysis of the main factors of negative technological processes in coal mines, the imperfections of the technology for localizing coal dust explosions, limiting a further increase in the efficiency of extraction and deep processing of mineral raw materials. In developing the mathematical model of hydrovortex coagulation, the decisive role of vorticity dispersion in the destruction of the absorption shell of a liquid drop in the zone of contact with a dust particle is shown. A differential equation of the motion of dust particles is obtained taking into account the effect of vorticity dispersion, its homogeneity is proved with the equation of plane motion of a viscous incompressible fluid, and independent parameters of the vortex inertial orthokinetic heterocoagulation are determined. Similarity criteria were determined, and the criterion equations of circulating dust suppression were constructed on the basis of a modified mathematical model of vortex kinematic interaction in the "liquid-solid" system. The decisive role of the Stokes criterion and the possibility of reducing its critical values in the process of hydro-vortex absorption of dust particles are proved. A significant decrease in the energy required for the complete absorption of dust particles, rotating droplets of liquid, water flow and the medial diameter of the absorbed dust is shown to be compared with classical hydrodesulfurization, which increases the efficiency of localization of the explosion of fine dust aerosols. The design of a hydro-vortex nozzle, a device for localizing explosions of dust mixtures, is proposed.

КлючевЫе слова: ГОМОГЕННОСТЬ, КРИТЕРИИ, ИНДИКАТОРЫ ПОДОБИЯ, УГОЛ СМАЧИВАНИЯ, КОЭФФИЦИЕНТ ЗАХВАТА.

Keywords: HOMOGENEITY, CRITERIA, INDICATORS OF SIMILARITY, WETTING ANGLE, CAPTURE COEFFICIENT. 


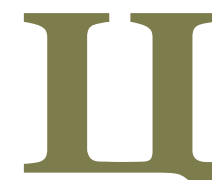

ель. Установить гомогенность уравнений классической и гидровихревой коагуляции построить критериальное уравнение на бае модифицированной математической модели гидровихревого пылеподавления.

Методология исследований. Предложена научная идея зависимости увеличения эффективного диаметра капли жидкости в зоне контакта и краевого угла смачивания от диффузии завихренности, определяемой угловой скоростью вращения капли жидкости и вязкостью газа, что способствует разрушению ее адгезионной оболочки и снижению потребной энергии полного поглощения.

На базе правила Фурье и П-теоремы построены критериальные уравнения гидровихревой коагуляции, получено выражение для критического значения критерия Стокса и относительного коэффрициента эффрективности.

Результаты. Подтверждена гомогенность уравнений классической и гидровихревой коагуляции, обоснованность использования уравнения Бусинеска при вихревом движении капель жидкости, уточнены независимые параметры, описывающие гидровихревую коагуляцию. Сертификационные испытания с применением защищённые патентом установки динамического пылеподавления подтвердили достаточность принятых критериев подобия гидровихревой инерционной ортокинетической гетерокоагуляции для подтверждения достоверности результатов прототипирования в лабораторных и промышленных условиях. Показано, что динамическая гидровихревая коагуляция существенно снижает размер диспергированного состава аэрозоли, расход воды, повышая эффективность локализации взрывов.

Область применения. С использованием предложенной математической модели разработана конструкция установки динамического пылеподавления с гидровихревой форсункой АСПВ-МДВ для локализации зон образования мелкодисперсных взрывоопасных пылевых смесей, предотвращения техногенных аварий, а горных предприятиях.

Введение. Наиболее распространенным способом осаждения пыли из воздуха является пылеподавление, основанное на смачивании аэрозолей каплями жидкости при соударении с образованием при этом гетерокоагуляционной системы «жидкое-твердое» которая выпадает из воздуха и осаждается на стенки выработки [1-6].

Определяющую роль в увеличении эффективности коагуляционного взаимодействия капель воды и аэрозоли играет именно кинетическая энергия движения капель распыляемой воды, а не общий ее расход [7, 8].

Актуальность совершенствования технологии высоконапорного гидрообеспыливания, внедрения экологического недропользования потребовала нового подхода к построению математической модели инерционной ортокинетической гетерокоагуляции воднопылевого аэрозоля [9-12].

В статьях [11, 12] предложена модель гидровихревого инерционного пылеподавления, исследован механизм ортокинетической коагуляции в условиях действия присоединенного вихря. Однако эффрект присоединенного вихря не раскрывает механизма влияния фризических характеристик системы «жидкое-твердое», геометрических и кинематических параметров, изменяющихся в связи с вращением, капли жидкости, с угловой скоростью $\omega_{ж}$ относительно ее поступательной скорости $V_{\text {ж}}$, на характер изменения процесса поглощения, критериев подобия, условия гомогенности уравнений движения.

Для целенаправленного совершенствования техники и технологии гидровихревой коагуляции, ускорения ее внедрения в целях повышения эфффективности локализации взрывов мелкодисперсной аэрозоли, необходимо развить научную идею изложенную в статье [12], установив связь расклинивающего давления газа с геометрическими и кинематическими параметрами в зоне контакта, гомогенность уравнений классической и гидровихревой коагуляции, зависимость определяющего критерия подобия от индикаторов, обеспечив тем самым достоверность и идентичность уравнений гидровихревой коагуляции при прототипировании и в реальных условиях.

Методология и методика исследований. В развитие научной идеи о присоединенном вихре, создающим разрежение в зоне контакта при гидровихревой коагуляции [11] примем, что диффузия завихренности, идентичная дифффузии в условиях циркуляции вязкой несжимаемой жидкости в замкнутом объеме, способствует уменьшению расклинивающего действия газа, т. е. разрушению адгезионной оболочки капли жидкости в зоне контакта площадью $S_{K}=\frac{\pi}{4} \cdot d_{\mathrm{n}}^{2} \sin ^{2} \theta_{\omega}[13]$.

Таким образом, увеличение краевого угла смачивания $\theta_{\omega}$ обусловленное угловой скоростью вращения капли жидкости $\omega_{ж}$ с учетом [7, $11,12]$ снижает энергию полного поглощения частицы пыли каплей жидкости пропорционально коэффициенту диффрузии завихренности, определяемому по фрормуле: 


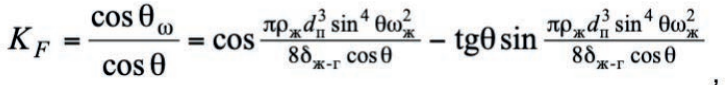

где $d_{n}$ - минимальный диаметр поглощаемой частицы пыли, м; $\rho_{n}, \rho_{2}-$ плотность частицы пыли

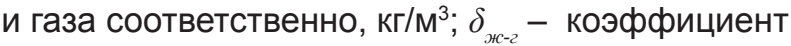
поверхностного натяжения на границе раздела двух сред «жидкость-газ», Дж/м²; $\theta$ - краевой угол смачивания на границе раздела двух сред «жидкость-газ» в условиях классической гетерокоагуляции, рад.

Обеспечение кинематического и геометрического подобия позволяет при моделировании заменить изучение сложных процессов адсорбционного взаимодействия, расклинивающего давления газовой среды на границе «твердоежидкое», исследованием влияния кинематических параметров $\omega_{ж}, V_{ж}$ на процесс гидровихревой коагуляции с соблюдением геометрического и кинематического подобия.

Согласно [13] коэффрициент дифффузии завихренности при движении вязкой несжимаемой жидкостивциркуляционномпотокеравен $\frac{\mu_{\Gamma}}{\rho_{\Pi}-\rho_{\Gamma}}$

т. е. соответствует кинематической вязкости газового потока при определении критерия Рейнольдса соответствующего отношению сил инерции и вязкости. Таким образом механизм действия диффузии завихренности идентичен механизму влияния вязкости в процессе передачи энергии соответственно при циркуляционном и поступательном движении, указанное подтверждает обоснованность научной идеи о передаче механической энергии вращения капли жидкости в газовой среде, в которой перемещается частица пыли, за счет дисперсии, т. е. распространения завихренности.

Диффференциальное уравнение Стокса движения частицы пыли в вязкой несжимаемой среды при вращении капли жидкости с угловой скоростью $\omega_{ж}$ может быть представлено в фрормe [13]:

$$
\frac{d \omega_{\text {ж }}}{d t}-\left(\omega_{\text {ж }} \cdot \nabla\right)\left(V_{\text {ж }}-V_{\Gamma}\right)=\frac{\mu_{\Gamma}}{\rho_{\Pi}-\rho_{\Gamma}} \nabla^{2} \omega_{\text {ж }},
$$

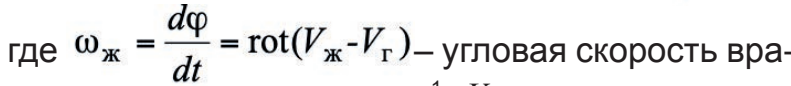
щения капли жидкости, $\mathrm{c}^{-1} ; V_{ж}$ - скорость капли жидкости равная скорости частицы пыли, м/с; $V$ - скорость газа, равная скорости частицы пыли, м/с; $\mu_{2}$ - коэффициент динамической вязкости газа, кг/мс.

Правая часть уравнения (2) представляет собой диффузию завихренности, т. е. фрактически отражает процесс преобразования энергии, обусловленной угловой скоростью вращения капли жидкости, вектор поступательной ско- рости которой $\left(V_{ж}-V\right)$ расположен в плоскости движения аэрозоля, в энергию вращения газа в котором перемещаются частицы пыли. Таким образом, в условиях гидровихревого взаимодействия аэрозоля и капли жидкости в газовой среде коэффициентом диффузии завихренности является кинематическая вязкость, как и в уравнении поступательного движения классической коагуляции при определении критерия Рейнольдса. Указанное подтверждает тождественность влияния дисперсии завихренности при гидровихревой коагуляции и диффузии в условиях классического столкновения на взаимодействие аэрозоли и капель жидкости, через газовую среду в которой они перемещаются.

Таким образом, с достаточной точностью процесс гидровихревой коагуляции можно рассматривать в условиях плоского движения с учетом дополнительного влияния диффрузии завихренности на энергетические характеристики взаимодействия аэрозоли и капель жидкости посредством газовой среды в процессе коагуляции, определяемые через изменение кинематических параметров.

Уравнение (2) в полярных координатах примет вид:

$$
\frac{\mu_{\Gamma}}{\rho_{\Pi}-\rho_{г}} \frac{d^{2} \omega_{ж}}{d r^{2}}+\frac{1}{r} \cdot \frac{d \omega_{ж}}{d r}=0
$$

где $r$ - радиус вектор положения частиц пыли.

Полученное уравнение тождественно уравнению распространения тепла, что подтверждает обоснованность выше указанного упрощения и гомогенность дифференциальных уравнений классической и гидровихревой гетерокоагуляции [13].

С учетом закона Био-Савара вращающуюся каплю жидкости можно представить как конечную вихревую нить, которая создает соответствующую циркуляцию скорости движения газа и частиц пыли [13].

Таким образом, влияние $\omega_{ж}$ в процессе вихревой коагуляции за счет дисперсии завихренности снижая расклинивающее действия газовой среды, увеличивая краевой угол смачивания фактически увеличивает инерционные силы по сравнению с силами вязкости, увеличивает эфрфективный диаметр капли жидкости, т. е. увеличивает значения критериев Рейнольдса и Стокса $[11,12]$.

Для проведения экспериментальных исследований и обоснованного использования полученных результатов необходимо установление критериев подобия соответствующих конкретным фризическим процессам гидровихревой 
коагуляции и построения критериального уравнения гидровихревого инерционного ортокинетического пылеподавления.

В качестве основных независимых параметров, определяющих механизм гидровихревой инерционной ортокинетической коагуляции с учетом правила Фурье и П-теоремы примем: геометрические параметры $d, d, d$; кинематические параметры $\sqrt{\left(V_{\text {ж }}-V_{\mathrm{r}}\right)^{2}+0,25 \omega_{\text {ж}}^{2} d_{\Pi}^{2} \cdot \sin ^{2} \theta \omega}=\left(V_{\text {ж }}-V_{\mathrm{r}}\right)_{э \phi}$ $\omega_{ж}$; динамические параметры $\left(\rho_{\text {п }}-\rho_{\mathrm{r}}\right), \rho_{\mathrm{r}}, \mu_{\mathrm{r}}$.

Для построения критериального уравнения гидровихревой инерционной ортокинетической коагуляции запишем взаимозависимость вышеуказанных независимых переменных в форме безразмерной степенной зависимости:

$$
\begin{gathered}
\text { Stk }_{\Pi \omega}=k d_{\text {ж}}^{a} d_{\Pi}^{\beta} \mu_{\Gamma}^{\delta} \rho_{\Gamma}^{y}\left(\rho_{\Pi}-\rho_{\Gamma}\right)^{z} . \\
\cdot\left(\sqrt{\left(V_{\text {ж }}-V_{\Gamma}\right)^{2}+0,25 \omega_{ж}^{2} d_{\Pi}^{2} \cdot \sin ^{2} \theta \omega}\right)^{x}\left(\omega_{ж}\right)^{\rho} d_{\mathrm{cm}}^{\psi} .
\end{gathered}
$$

Для нахождения критериев подобия составим полную матрицу размерностей независимых параметров.

$$
\|M\|=\begin{array}{|c|c|c|c|c|c|c|c|c|} 
& d_{\text {ж }} & d_{\mathrm{I}} & \mu_{\mathrm{r}} & \rho_{\mathrm{r}} & \rho_{\mathrm{I}}-\rho_{\mathrm{\Gamma}} & \sqrt{\left(V_{\text {Ж }}-V_{\mathrm{\Gamma}}\right)^{2}+0,25 d_{\mathrm{CM}}^{2} \omega_{\text {Ж }}^{2}} & \omega_{\text {ж }} & d_{\mathrm{CM}} \\
\cline { 1 - 8 } & 1 & 1 & -1 & -3 & -3 & 1 & 0 & 1 \\
\hline L & 0 & 0 & 1 & 1 & 1 & 0 & 0 & 1 \\
\hline T & 0 & 0 & -1 & 0 & 0 & -1 & -1 & 0
\end{array}
$$

Ранг матрицы $\|M\|=3$, следовательно количество чисел подобия равно пяти.

Показатели степени $\alpha, \beta, \delta, y, z, x, \varphi, \psi$ в критериальном уравнении по элементам матрицы (5) составляют однородную систему линейных уравнений:

$$
\left\{\begin{array}{c}
\alpha+\beta-\gamma-3 y-3 z+x+\psi=0 \\
\gamma+y+z=0 \\
\gamma+x+\varphi=0
\end{array}\right.
$$

В соответствии с решением системы уравнений (6) получаем матрицу чисел подобия:

$\left\|M_{\pi}\right\|=$\begin{tabular}{|c|c|c|c|c|c|c|c|c|} 
& $d_{\text {ж }}$ & $d_{\mathrm{\Pi}}$ & $\mu_{\mathrm{r}}$ & $\rho_{\mathrm{r}}$ & $\rho_{\mathrm{\pi}}-\rho_{\mathrm{r}}$ & $\sqrt{\left(V_{\text {ж }}-V_{\mathrm{\Gamma}}\right)^{2}+0,25 d_{\mathrm{cM}}^{2} \omega_{\text {\% }}^{2}}$ & $\omega_{\text {ж }}$ & $d_{\mathrm{cM}}$ \\
\hline$\pi_{1}$ & 0 & 2 & -2 & 2 & 0 & 2 & 2 & -1 \\
\hline$\pi_{2}$ & -1 & 0 & 1 & -1 & 0 & -1 & -1 & -1 \\
\hline$\pi_{3}$ & 0 & 0 & 0 & -1 & 1 & 0 & 0 & 0 \\
\hline$\pi_{4}$ & 0 & 1 & 0 & 0 & 0 & -1 & 1 & 1 \\
\hline$\pi_{5}$ & 0 & -1 & 0 & 0 & 0 & 0 & 0 & 1 \\
\hline & $\alpha$ & $\beta$ & $\gamma$ & $y$ & $z$ & $x$ & $\varphi$ & $\psi$
\end{tabular}

Раскрывая соответствующие определители вышеуказанной матрицы построим пять безразмерных комплексов, представляющих собой индикаторы подобия:

$$
\begin{gathered}
\pi_{1}=\frac{\left.\rho_{\mathrm{r}}^{2} d_{\mathrm{I}}^{2}\left(V_{\text {ж }}-V_{\mathrm{r}}\right)^{2}+0,25 \omega_{ж}^{2} d_{\mathrm{cM}}^{2}\right)}{\mu_{\mathrm{r}}^{2}}=\operatorname{Re}_{\mathrm{\Pi}}^{2} ; \\
\pi_{2}=\frac{\mu_{\mathrm{r}}}{d_{\text {ж }} \rho_{\mathrm{r}} \sqrt{\left(V_{\text {ж }}-V_{\mathrm{r}}\right)^{2}}+0,25 \omega_{ж}^{2} d_{\mathrm{cM}}^{2}}=\operatorname{Re}_{\%}^{-1}
\end{gathered}
$$

$$
\begin{gathered}
\pi_{3}=\frac{\rho_{\mathrm{II}}-\rho_{\mathrm{\Gamma}}}{\rho_{\mathrm{\Gamma}}}=\pi_{\rho}=\operatorname{Ard}_{\mathrm{cT}} \\
\pi_{4}=\frac{\omega_{\text {}} d_{\mathrm{\Pi}} \sin \theta_{\omega}}{2 \sqrt{\left(V_{\text {}}-V_{\mathrm{r}}\right)^{2}+0,25 \omega_{\mathrm{K}} d_{\mathrm{I}}^{2} \sin \theta_{\omega}^{2}}}=\pi_{k} \\
\pi_{5}=\frac{1}{\sin \theta_{\omega}}=\pi_{\mathrm{r}}^{-1}
\end{gathered}
$$

где $R e_{\text {п, ж}}-$ критерий Рейнольдса для частицы пыли и капли жидкости; Ard ст - статический критерий Архимеда; $\pi_{k}$ - кинематический критерий подобия, идентичный $\alpha$; $\pi_{\text {г }}$ геометрический критерий подобия, идентичный $\theta_{\omega}$.

Коэффрициент пропорциональности $k$ в уравнении (4) определяем из выражения для времени релаксации при установившемся стоксовском движении капли жидкости, т.е. при $R=1$ $[7]$.

С учетом вышеизложенного, уравнение (4) запишем в критериальной форме:

$$
\begin{aligned}
& \mathrm{Stk}_{\text {п }}=\frac{l_{\Pi}}{d_{\text {ж }}}=\frac{\operatorname{Re}_{\Pi}^{2}}{18 \operatorname{Re}_{ж}} \operatorname{Ard}_{\mathrm{cr}} \cdot \pi_{k} \cdot \pi_{\mathrm{\Gamma}} \\
& \mathrm{Stk}_{\text {пा }}=\frac{l_{\text {П }}}{d_{\text {ж }}}=\frac{\operatorname{Re}_{\mathrm{\Pi}} d_{\text {п }}}{18 d_{\text {ж }}} \operatorname{Ard}_{\mathrm{cr}} \cdot \pi_{k} \cdot \pi_{\mathrm{r}} \quad=\text { idem. } \\
& \mathrm{Stk}_{\text {п }}=\frac{l_{\text {П }}}{d_{\text {ж }}}=\frac{\tau_{\text {П }} \sqrt{\left(V_{\text {ж }}-V_{\mathrm{\Gamma}}\right)^{2}+0,25 \omega_{\text {ж }} d_{\Pi}^{2} \sin \theta_{\omega}^{2}}}{d_{\text {ж }}}
\end{aligned}
$$

Результаты исследований. С учетом статей $[11,12]$ выражение для критического значения «инерционного параметра» Стокса получим в виде:

$$
\mathrm{Stk}_{\text {пा кр }}=\frac{\tau_{\text {п }} \sqrt{\frac{24 \delta_{\text {ж-г }} \cdot \cos \theta_{\omega}}{\left(\rho_{\mathrm{n}}-\rho_{\mathrm{r}}\right) d_{\mathrm{n}}}}}{d_{\text {ж }}} .
$$

Таким образом, задача определения эффективности коагуляции в условиях гидровихревого инерционного ортокинетического столкновения заключается в установлении зависимости критического значения инерционного критерия

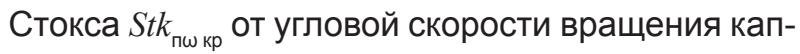
ли $\omega_{ж}$ жидкости и диаметра пылинки $d_{n \omega}$.

В статье [7] установлено существование критического значения критерия Стокса $S t k_{n \text { кр }}$ в условиях классической гетерокоагуляции при котором эффрективность столкновения $K_{S}=0$.

При $S t k_{\text {пш }}>S t k_{\text {пш кр }}$ с учетом статьи [7] и выше сказанного, относительный коэффициент эффективности столкновения в условиях гидровихревой коагуляции по отношению классической коагуляции можно представить в виде:

$$
K_{S \omega}=K_{S} \cdot\left(1+\frac{0,25 \omega_{ж} d_{\Pi} \cdot \sin \theta \omega}{\left(V_{ж}-V_{\Gamma}\right)}\right) \text {. }
$$

С учетом формул $(10,11)$ автомодельный режим гидровихревого инерционного ортокинетического столкновения, при котором аэродинамический энергетический барьер не позволяет 
осуществить коагуляционное взаимодействие, т. е. переход системы «твердое-жидкое» в стабильное энергетическое состояние смещается в область меньших значений критерия Стокса, а коэффициент эффрективности столкновения возрастает по сравнению с классической коагуляцией.

Предложенная математическая модель позволила спроектировать и защитить патентом установку динамического гидровихревого пылеподавления [15].

С целью установления достоверности полученных формул и критериальных уравнений были проведены экспериментальные исследования для установления зависимости критического значения критерия Стокса $S t k_{\text {п кр }}$ и коэфициента эфффективности столкновения от угловой скорости вращения капли жидкости $\omega_{\text {жс }}$, и диаметра частиц поглощаемой пыли $d_{n \omega}$

На рис. 1 приведены результаты расчета по предложенным критериальным уравнениям вихревой инерционной ортокинетической коагуляции изменения критических значений «инер-

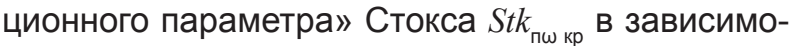
сти от угловой скорости вращения капель воды $\omega_{ж}$ диаметром $d_{ж}=4,5 \cdot 10^{-6}$ м и диаметра частиц угольной пыли $\mathrm{d}_{\text {пш }}$ при значении критерия Рейнольдса капли жидкости $R_{\text {ж }}=20$.

По мере снижения диаметра частиц угольной пыли $d_{n \omega}$ для обеспечения эфрфективной гидровихревой коагуляции необходимо увеличивать угловую скорость вращения капель воды $\omega_{ж}$, что согласно предложенной модели и результатов эксперимента способствует снижению критического значения «инерционного параметра» $S t k_{\text {пш кр }}$

Из анализа рис. 2. Следует, что с увеличением угловой скорости вращения капель жидкости $\omega_{\text {ж}}$, наблюдается заметный рост коэффициента эффрективности столкновения $K S_{\omega}$ что также способствует росту эффективности коагуляции снижению критических значений критерия Стокca.

Проведенные экспериментальные исследования подтвердили достаточную достоверность критериального уравнения гидровихревой инерционной ортокинетической коагуляции для применения его в целях обеспечения идентичности результатов моделей испытаний с реальными фризическими процессами пылеподавления. Результаты расчетов с учетом предложенного уточнения научной идеи, полученных критериальных уравнений, показали высокую эффрективность гидровихревой инерционной ортокинетической коагуляции, позволившей по-

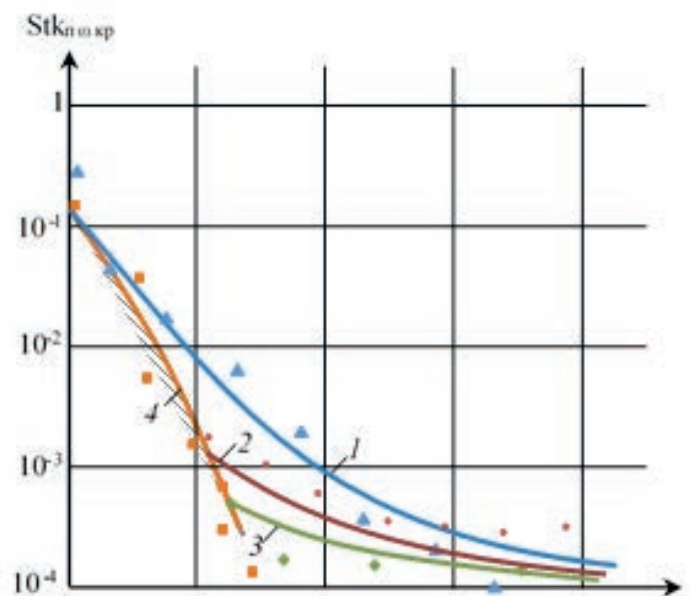

Рисунок 1. Зависимость критических значений критерия Стокса от угловой скорости вращения капель жидкости $\omega_{\text {ж }}$ для различных диаметров частиц пыли $1-d_{0}=5 \cdot 10^{-6} \mathrm{M} ; 2-d_{\text {п }}=2 \cdot 10^{-6} \mathrm{M} ; 3$ $-d_{1}=5 \cdot 10^{-7} \mathrm{M} ; 4$ - граница автомодельности гидровихревой коагуляции

Figure 1 - The dependence of the critical values of the Stokes criterion on the angular velocity of rotation of liquid droplets wzh for various diameters of dust particles is $1-d n=5 \cdot 10-6 \mathrm{~m} ; 2-d n=2 \cdot 10-6 \mathrm{~m} ; 3-d n=5 \cdot 10-7$ $m ; 4$ - the boundary of self-similarity of vortex coagulation

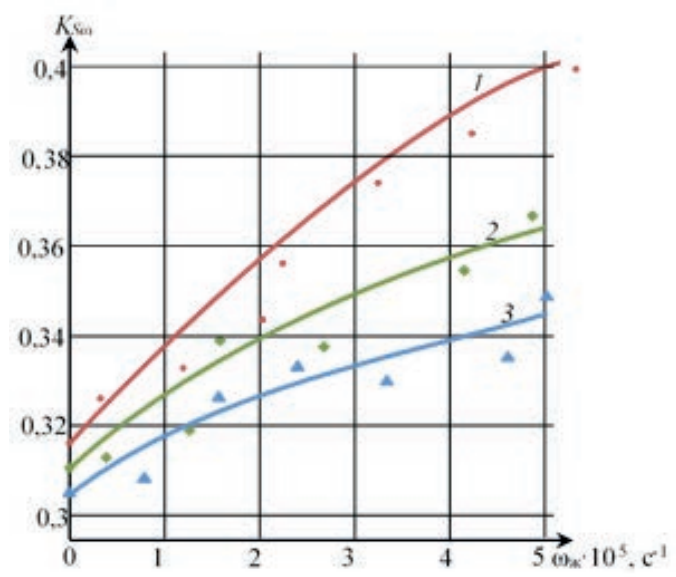

Рисунок 2. Зависимость коэффрициента эфрфективности столкновения от угловой скорости вращения капель жидкости $\omega_{*}: 1-d_{\text {* }}=10^{-4} \mathrm{M}$; 2 $d_{*}=8 \cdot 10^{-5} \mathrm{M} ; 3-d_{*}^{*}=5 \cdot 10^{-5} \mathrm{M}$

Figure 2 - The dependence of the collision efficiency coefficient on the angular velocity of rotation of the liquid droplets wzh: 1 - dzh $=10-4 \mathrm{~m} ; 2$ - dzh $=8 \cdot 10-5 \mathrm{~m} ; 3$ $d z h=5 \cdot 10-5 m$

высить эффрективность пылеподавления до 99 \% в сравнении с классическим высоконапорным гидрообеспыливанием.

\section{Выводы}

1. Подтверждена достоверность научной идеи об идентичности влияния вязкости при классической коагуляции и дифффузии завихренности при гидровихревой коагуляции.

2. Доказано снижение критических значений критерия Стокса в процессе гидровихревой 
инерционной ортокинетической коагуляции с увеличением угловой скорости вращения $\omega_{*}$ капель жидкости.

3. Подтверждено снижение расклинивающего давления газовой среды на границе «твердое-жидкое» за счет вращения капель жидкости.
4. Доказана эфффективность гидровихревой инерционной ортокинетической коагуляции для локализации взрывов аэрозолей в диапазоне $d_{n \omega}=\left(5-0,6 \cdot 10^{-6}, \mathrm{M}\right)$.

\section{СПИСОК ЛИТЕРАТУРЫ}

1. Cecala A.B., Dust A.D. Control handbook for industrials minerals mining and processing / Office of Mine safety and Health Research, 2012. - 159 c.

2. Makarov V.N., Davydov S.Ya. Theoretical basis for increasing ventilation efficiency in technological processes at industrial enterprises // Refractories and Industrial Ceramics. - 2015. - Vol. 56, iss. 1. - P. 103-106. DOI: 10.1007/ s11148-015-9791-7.

3. Recirculation filter is key to improving dust control in enclosed cabs: Technology news 528. Pittsburgh: Department of Health and Human Services, Centers for Disease Control and Prevention, National Institute for Occupational Safety and Health, DHHS (NIOSH), 2007. - Publication No. 2008-100.

4. Либецкий К. Пылевые опасности в горнодобывающей промышленности // Главный институт горного дела, Польша. - Катовице, 2004. 486 с.

5. Wu D., Yin K., Yin Q., Zhang X., Cheng J., Ge D., Zhang P. Reverse circulation drilling method based on a supersonic nozzle for dust control // Applied Sciences (Switzerland). - 2017. - T. 7, № 1. - P. 5-20. DOI: 10.3390/app7010005

6. Скопинцева О.В., Прокопович А.Ю., Соловьев Ю.В. Исследование пылеобразующей способности углей при увлажнении их рабочей жидкостью в режиме капиллярного насыщения // Горный информационно-аналитический бюллетень. - 2008. - № 9. С. 68-70.

7. Фролов А.В., Телегин В.А., Сечкерев Ю.А. Основы гидрообеспыливания. Безопасность жизнедеятельности. 2007. - № 10. - C. 1-24.

8. A method of additive aerodynamic calculation of the friction gear classification block / Makarov V.N., Potapov V.Ya., Davydov S.Ya., Makarov N.V. // Refractions and Industrial Ceramics. - 2017. - Vol. 38, № 3. - P. 288-292. DOI: 10.1007/s11148-017-0098-8

9. Bautin S.P. Mathematical simulation of the vertical part of an upward swirling flow // High temperature. - 2014. - T. 52, №2 - C. 259-263. DOI: 10.1134/S0018151X14020035

10. Способ создания подъёмной силы и устройства для его осуществления: патент 2601495 Рос. Федерация М.кл. В64С23/0,6 / Макаров Н.В., Макаров В.Н., заявл.: 22.06.2015, опубл.: 11.10.2016.

11. Макаров В.Н., Косарев Н.П., Макаров Н.В., Угольников А.В., Лифанов А.В. Эфффективная локализация взрывов угольной пыли с использованием гидровихревой коагуляции. Вестник пермского национального исследовательского политехнического университета. Геология. Нефртегазовое и горное дело № 2, Т. 18, 2018. С. $178-189$.

12. Макаров В.Н., Макаров Н.В., Потапов В.В., Горшкова Э.М. Перспективный способ повышения эфффективности высоконапорного гидрообеспыливания. Вестник ЗабГУ. 2018. Т. 24 № 5. С. 13-20.

13. Лойцянский Л.Г. Механика жидкости и газа. Учебник для вузов. - 7-е изд., испр. - М.: Дрофра, 2003. - 840 с.

14. Веников В.А. Теория подобия и моделирования применительно к задачам электроэнергетики. - М.: Высшая школа, 1966. - 487 с.

15. Установка динамического пылеподавления: патент 2575372 Рос. Федерация / Макаров В.Н., Горшкова Н.А. Чуркин В.А, заявл.: 20.11.2014, опубл.: 20.02.2016.

\section{СПИСОК ЛИТЕРАТУРЫ}

1. Cecala, A.B.,\& Dust, A.D. (2012). Control handbook for industrials minerals mining and processing. Office of Mine safety and Health Research. [In Russian].

2. Makarov, V.N., \& Davydov, S.Ya. (2015). Theoretical basis for increasing ventilation efficiency in technological processes at industrial enterprises. Refractories and Industrial Ceramics, 3(1), 103-106. DOI: 10.1007 / s11148-0159791-7. [In Russian].

3. Recirculation filter is key to improving dust control in enclosed cabs: Technology news 528. Pittsburgh: Department of Health and Human Services, Centers for Disease Control and Prevention. (2007) National Institute for Occupational Safety and Health, DHHS (NIOSH) Publication No . 2008-100.

4. Libetskiy, K. (2004). Dust hazards in the mining industry. Main Institute of Mining, Poland, Katowice.

5. Wu, D., Yin, K., Yin, Q., Zhang, X., Cheng, J., Ge, D., \& Zhang, P. (2016). Reverse Circulation Drilling Method Based on a Supersonic Nozzle for Dust Control. Applied Sciences, 7(1), 5-20. doi: 10.3390/app7010005

6. Skopintseva, O.V., Prokopovich, A.Yu., Soloviev, \& Yu.V. (2008). Investigation of the dust-forming ability of coals when moistened with their working fluid in the capillary saturation mode. Mountain Information and Analytical Bulletin, 9 , 68-70. [In Russian].

7. Frolov, A.V., Telegin, V.A., Sechkerev, \& Yu.A. Basics of dedusting. (2007). Life safety, 10, 1-24. [In Russian].

8. Makarov, V.N., Potapov, V.Ya., Davydov, S.Ya., \& Makarov, N.V. (2017). A method of additive aerodynamic calculation of the friction gear classification block. Refractions and Industrial Ceramics, 38 (3), 288-292. DOI: 10.1007 / s11148017-0098-8 [In Russian]

9. Bautin, S. P. (2014). Mathematical simulation of the vertical part of an upward swirling flow. High Temperature, 52(2), 259-263. doi: 10.1134/s0018151x14020035

10. Makarov N.V., Makarov V.N. (2016). A method of creating a lifting force and a device for its implementation: patent 2601495 Ros. Federation M.cl.V64C23, application .: 06.22.2015, publ.: 11.10.2016. [In Russian]

11. Makarov, V.N., Kosarev, N.P., Makarov, N.V., Ugolnikov, A.V., \& Lifanov, A.V. (2018). Effective localization of coal dust 
explosions using hydro-vortex coagulation. Bulletin of the Perm National Research Polytechnic University. Geology. Oil and Gas and Mining, 2(18), 178-189. [In Russian]

12. Makarov, V.N., Makarov, N.V., Potapov, V.V., \& Gorshkova, E.M. (2018). A promising way to increase the efficiency of high-pressure hydrodedusting. Bulletin of ZabSU, 24(5), 13-20. [In Russian]

13. Loytsyansky, L.G. (2003). Mechanics of fluid and gas. Textbook for high schools. - 7th ed. Rev. Moscow - Bustard. [In Russian].

14. Venikov, V.A. (1966). The theory of similarity and modeling as applied to the tasks of the electric power industry. Moscow - Higher School. [In Russian]

15. Makarov, V.N., Gorshkova, N.A., \& Churkin, V.A. (2016). Installation of dynamic dust suppression: patent 2575372 Ros. Federation application .: 11/20/2014, publ.: 02.20.2016. [In Russian]

\section{ООО "ГОРНЫЙ-ЦОТ "}

серийно производит приборы контроля параметров безопасности рудничной атмосферы угольных шахт, которые успешно эксплуатируются на предприятиях угольной отрасли. Сегодня благодаря их успешному применению на шахтах компания стала надежным звеном в решении проблем промышленной безопасности как в России, так и за ее пределами.

\section{ВЫПУСКАЕМЫЕ ПРИБОРЫ}

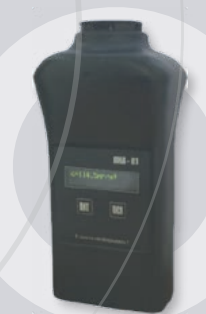

Прибор контроля запыленности возАуха ПКА-01

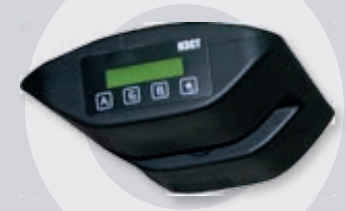

Измеритель запыленности стационарный ИЗСТ-01

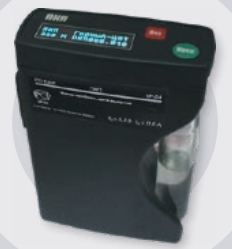

Прибор контроля пылевзрывобезопасности горных выработок ПКП

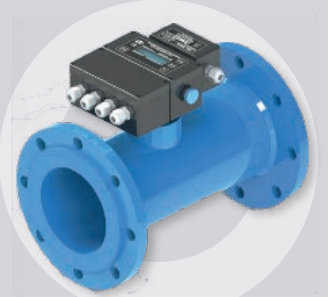

Система контроля параметров Аегазационной сети СКП АС

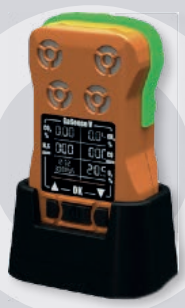

Портативные газоанализаторы GaSense (1-,2-,3-,4-газовые)

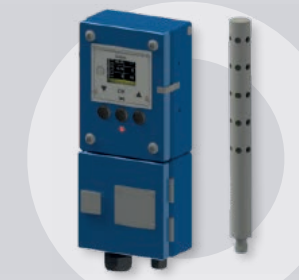

Стационарный анализатор контроля параметров атмосферы Gasos заперемычного пространства

а так же оказывает услуги следующих направлений:

- разработка систем измерения кАиматических параметров руАничной атмосферы (температуры; влажности; скорости и направления ветра; Аавления);

- разработка программного обеспечения А^я встраиваемых систем;
- разработка приборов по инАивиАуамьным заказам, в т.ч. по схеме no-name;

- организация провеАения ремонта вышеуказанных серийно выпускаемых приборов и их испытаний с целью поверки. 


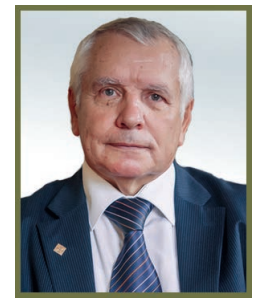

А. И. Фомин // A. I. Fomin ncvostnii@yandex.ru

д-р техн. наук, ведущий научный сотрудник отдела АО "НЦ ВостНИИ", Россия, 650002 , г. Кемерово, ул. Институтская, 3 doctor of technical sciences, department leading scientific researcher, JSC «ScC VostNII», 3, Institutskaya Str., Kemerovo, 650002, Russia

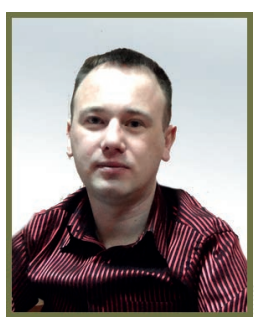

Д.А. Бесперстов//

D.A. Besperstov gpnbesperstov@yandex.ru

канд. техн. наук, доцент кафедры "Техносферная безопасность" ФГБОУ ВПО "Кемеровский государственный университет" г. Кемерово. Россия, 650056 г. Кемерово, Бульвар Строителей, д. 47.

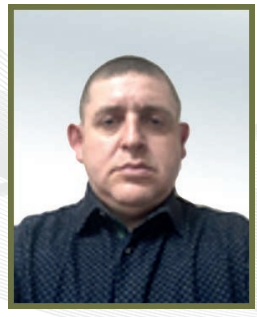

O.B. Рудюк// O.V. Rudyuk rudyuk_o.v@mail.ru

магистрант ФГБОУ ВО «Сибирская пожарно - спасательная академия ГПС МЧС России», Россия, 662972 , Красноярский край, г. Железногорск, ул. Северная, 1

УДК 614.849

\author{
ОБЕСПЕЧЕНИЕ БЕЗОПАСНОСТИ ГРАЖДАН В РАЙОНАХ \\ ПРОЖИВАНИЯ УГОЛЬНЫХ ПРЕДПРИЯТИЙ \\ ШЛАМООТСТОЙНИКИ \\ ENSURING THE SAFETY OF CITIZENS IN THE AREAS OF
RESIDENCE OF THE COAL ENTERPRISES. SLUDGE TRAPS
}

В настоящей статье приведены проблемы консервации ранее эксплуатируемых шламоотстойников. В работе предлагается решить проблему подземного горения шламоотстойников, законсервированных с нарушениями норм, посредством проведения мероприятий по предупреждению и ликвидации чрезвычайных ситуаций. Необходима организованная деятельность органов местного самоуправления по приведению вверенных территорий в безопасное состояние. Данная работа возможна, в том числе при реализации первичных мер пожарной безопасности, а также проведения мероприятий в соответствии с требованиями законодательства в области защиты населения и территорий от чрезвычайных ситуаций природного и техногенного характера.

Вместе с тем, в работе приведен ряд недостатков связанных с реализацией полномочий фредеральных органов исполнительной власти и субъектов Российской Федерации по ликвидации подземных загораний шламоотстойников, в связи с локальностью угроз возможного возникновения чрезвычайной ситуации.

This article describes the problems of conservation of previously operated sludge traps. The paper proposes to solve the problem of underground burning of sludge traps, mothballed with violations of the norms, through measures to prevent and eliminate emergency situations. Organized activities of local authorities are required to bring the entrusted territories into a safe state. This work is possible, including the implementation of primary fire safety measures, as well as the implementation of measures in accordance with the requirements of the legislation in the field of protecting the population and territories from natural and man-made emergencies.

At the same time, the paper cites a number of shortcomings related to the implementation of the powers of the federal executive bodies and constituent entities of the Russian Federation to eliminate underground fires of sludge traps, due to the locality of the threats of a possible emergency.

Ключевые слова: консервация шламоотстойников, безопасность населения, пожарная безопасность, защита от чрезвычайных ситуаций, первичные меры в области пожарной безопасности, предупреждение гибели людей.

Key words: preservation of sludge traps, public safety, fire safety, emergency protection, primary fire safety measures, prevention of death. 
A

ктуальность проведения работ по обеспечению безопасности шламоотстойников

В настоящее время на территории Кемеровской области, лидирующей по Российской Федерации в угольном производстве, присутствуют загорания шламоотстойников ранее законсервированных не один десяток лет назад. Особенно острый вопрос подземных пожаров возник в местах захоронения угольных хвостов угледобывающих и углеперерабатывающих предприятий действующих во времена СССР.

На рубеже эпох 80-90xx годов прошлого века, в результате смены государственной собственности на частную и прекращении деятельности значительного количества угольных предприятий осталось опасное наследие, выраженное в виде неправильной консервации остатков угледобычи. В результате данного возникают подземные пожары, которые приводят не только к экологическому ущербу, но и к человеческим жертвам.

Так на территории Кузбасса в 2017 году произошел трагический случай, погиб несовершеннолетний ребенок [1]. Согласно средств массовой информации, двое мальчиков гуляли в близости от своих домов. Увидев тление почвы они заинтересовались и подошли поближе. В результате провала детей под землю, в неогороженном месте расположения, бывшего шламоотстойника, произошло то, что один мальчик погиб, второй пострадал.

Данный случай особо остро показывает на необходимость надлежащей эксплуатации и дальнейшей консервации предприятий угледобычи и угольной переработки.

Нормативные правовые предпосылки предупреждения социально-экономического ущерба в результате пожаров, вызванных загораниями шламоотстойников

Основным понятием чрезвычайной ситуации является обстановка возникшая на определенной территории в результате негативных последствий аварий, природных явлений, стихий, катастрофф и других бедствий с возможным или имеющимся социально-экономическим ущербом, в том числе приводящих к нарушению условий жизнедеятельности людей [2].

В свою очередь, чрезвычайные ситуации классифицируются из условия материального ущерба и количества пострадавших [3]. Так, в зависимости от условий чрезвычайные ситуации характеризуются по следующим уровням: ло- кального, муниципального, межмуниципального, регионального, межрегионального и федерального характера.

Шламоотстойники изначально находятся на территории действующего предприятия и возникновение на них аварийных ситуаций может привести к чрезвычайной ситуации локального характера. Как правило, данные гидротехнические сооружения [4], при наличии собственника и контроля со стороны государства [5], эксплуатируются в соответствии с нормативно-правовыми актами Российской Федерации. В последствии, из-за высокой стоимости проведения консервации, данных опасных производственных объектов [6], зачастую, работы осуществляются с нарушениями и шламоотстойники передаются государству в ненадлежащем виде. Как правило, данное возможно реализовать при банкротстве угледобывающего или углеперерабатывающего предприятия на рубеже основания Российской Федерации, в конце 80-х, начале 90-х годов прошлого века. В указанный период времени, из-за перехода от СССР к новому государству, многие государственные институты, такие как органы местного самоуправления и органы Ростехнадзора, изменили свои юридические и функциональные положения, что привело к ослаблению контроля за недобросовестными объектами, консервирующих свои объекты с нарушениями норм.

В последствии, данные объекты стали представлять собой потенциальную опасность на территории муниципального образования, которые могут привести к чрезвычайной ситуации в результате подземного загорания углешламовых остатков шламоотстойников.

Вышеприведенная проблема ставит вопрос о необходимости принятия безотлагательных, исчерпывающих мер, по приведению в безопасное состояние земельных участков, на которых возможно возникновение подобных негативных ситуаций.

Меры по предупреждению возникновения чрезвычайных ситуаций в результате эндогенных пожаров шламоотстойников

В рассматриваемом случае эндогенный пожар может возникнуть в результате ненадлежащей эксплуатации и последующей консервации шламоотстойников. Данное возможно представить, как потенциальную опасность возникновения чрезвычайной ситуации, вследствие чего необходимо принятие ряда мер как функциональными, так и территориальными подсистемами единой государственной системы предупреждения и ликвидации чрезвычайных ситуа- 
ций (далее РСЧС) [7].

Так, при установлении гражданами или должностными лицами подземного пожара необходимо, незамедлительно сообщить о возникшей ситуации в органы местного самоуправления или в МЧС России, через единую дежурнодиспетчерскую службу (далее - ЕДДС) или в пожарно-спасательную часть, по телефонам «112» или «01», соответственно.

Далее силы оперативного реагирования прибывают на место возникновения ситуации. При непосредственной угрозе жизни, здоровью людей силы приступают к ликвидации чрезвычайной ситуации. Вместе с тем, прибывшим подразделением, информируется управление (отдел) ГО и ЧС города, района являющегося постоянно действующим органом управления, который должен принимать решения о сборе комиссии по чрезвычайной ситуации, на которой разрабатываются меры по ликвидации сложившейся ситуации и назначается ответственное лицо за проведение необходимых работ [2, 7].

Более подробно, методическими рекомендациями МЧС России определен следующий порядок действий сил и средств РСЧС [8].

В соответствии с пунктом 7 Приложения № 2 Методических рекомендаций по организации действий органов государственной власти и органов местного самоуправления при ликвидации чрезвычайных ситуаций, утвержденными решением Правительственной комиссии по предупреждению и ликвидации чрезвычайных ситуаций, и обеспечению пожарной безопасности (протокол № 4 от 17.04.2015) порядок действий Главы органа местного самоуправления (председателя КЧС и ОПБ) при ликвидации чрезвычайных ситуаций следующий:

1. Получение информации от дежурного ЕДДС (других источников) об угрозе (возникновении) ЧС, уточнение ее параметров.

2. Отдача распоряжения дежурному ЕДДС на:

- проведение оповещения и сбора личного состава территориальных органов Федеральных органов исполнительной власти, органов местного самоуправления, комиссии по предупреждению чрезвычайных ситуаций и обеспечения пожарной безопасности муниципального образования (далее КЧС и ОПБ МО), города, района (согласно списку);

- направление в зону ЧС оперативной группы (далее ОГ) КЧС и ОПБ и сил и средств первого эшелона.

3. Отдача распоряжения председателю КЧС и ОПБ администрации МО на:
- проведение заседания КЧС и ОПБ администрации МO;

- подготовки проекта распоряжения главы администрации МО на введение режима чрезвычайной ситуации;

- подготовку и направление сведений председателю КЧС и ОПБ субъекта Российской Федерации (через центр управления в кризисных ситуациях):

- подготовка донесений по установленным формам;

- разработка карты района ЧС;

- подготовка справки по силам и средствам, привлекаемым к ликвидации ЧС;

- текстового решения на ликвидацию ЧС.

4. Прием доклада дежурного ЕДДС о результатах оповещения.

5. На основе полученных данных об обстановке принимает предварительное решение.

6. Уточнение задачи дежурному ЕДДС по перечню должностных лиц, привлекаемых на уточнение задач.

7. Постановка (уточнение) главой администрации задач должностным лицам MO на организацию работ по ликвидации ЧС.

8. Контроль организации работ по ликвидации ЧС.

9. Оценка обстановки (на основе информации, полученной от ЕДДС, ОГ и других источников) и контроль подготовки проекта распоряжения главы администрации МО на введение режима чрезвычайной ситуации и определение руководителя работ по ликвидации ЧС.

10. Подписание распоряжения главы администрации МО на введение режима чрезвычайной ситуации. Направление в район ЧС сил и средств второго эшелона.

11. Контроль выработки КЧС и ОПБ предложений в решение на ликвидацию ЧС.

12. Контроль, через КЧС и ОПБ, ОГ, выполнения мероприятий по:

- непрерывному контролю за состоянием окружающей среды, прогнозированию развития возникших чрезвычайных ситуаций и их последствий;

- оповещению руководителей федеральных органов исполнительной власти, органов исполнительной власти субъекта, органов местного самоуправления и организаций, а также населения о возникших чрезвычайных ситуациях;

- проведению мероприятий по защите населения и территорий от чрезвычайных ситуаций;

- организации работ по ликвидации чрезвычайных ситуаций и всестороннему обеспе- 
чению действий сил и средств муниципального звена территориальной подсистемы РСЧС, поддержанию общественного порядка в ходе их проведения, а также привлечению при необходимости в установленном порядке общественных организаций и населения к ликвидации возникших чрезвычайных ситуаций;

- непрерывному сбору, анализу и обмену информацией об обстановке в зоне чрезвычайной ситуации и в ходе проведения работ по ее ликвидации;

- организации и поддержании непрерывного взаимодействия федеральных органов исполнительной власти, органов исполнительной власти субъекта, органов местного самоуправления и организаций по вопросам ликвидации чрезвычайных ситуаций и их последствий;

- проведению мероприятий по жизнеобеспечению населения в чрезвычайных ситуациях.

13. Подведение итогов работ за сутки, постановка задач на следующие сутки.

14. Доклад по завершению ликвидации председателю КЧС и ОПБ субъекта о выполнении работ, принятых решениях и проблемных вопросах.

15. Возвращение сил и средств в место постоянной дислокации. ции ЧС.

16. Контроль подготовки анализа ликвида-

Первичные меры по профилактике возникновения пожароопасных ситуаций на территории муниципальных образований.

Помимо законодательства в области защиты населения и территорий от чрезвычайных ситуаций порядок предупреждения и ликвидации загораний шламоотстойников предусмотрен в нормативно-правовых актах в области пожарной безопасности, в части реализации муници- пальными образованиями первичных мер.

В соответствии с законодательством Российской Федерации к первичным мерам по предупреждению пожаров и гибели людей в результате загораний шламоотстойников, относится реализация полномочий по организационной, правовой, финансовой, материальной и технической обеспеченности пожарной безопасности муниципальных образований $[9,10]$.

То есть муниципальное образование должно самостоятельно, из местных условий разрабатывать и финансировать необходимые мероприятия по предупреждению социальноэкономического ущерба [9].

\section{Заключение}

Из условий нормативно-технического регулирования можно сделать вывод о том, что обеспечение безопасности граждан в районах проживания угольных предприятий и надлежащее размещение шламоотстойников возложено в первую очередь на органы местного самоуправления. Данное обусловлено тем, что рассматриваемые опасные производственные объекты [6] расположены локально, в пределах одного муниципального образования, что является основанием необходимости проведения органами местного самоуправления первичных мер. Вместе с тем, необходимо не забывать о критериях классификации чрезвычайных ситуаций, в соответствии с которыми вопросы обеспечения безопасности угольных предприятий, в том числе прекративших свою деятельность могут принимать региональные или федеральные масштабы. Необходимо отнесение объектов к опасным производственным, не исходя из юридических, формальных оснований, а по фрактическому пожароопасному состоянию.

\section{СПИСОК ЛИТЕРАТУРЫ}

1. В Кузбассе двое детей упали в горящую яму со шлаком, один мальчик погиб [Электронный pecypc]: URL: https://www.city-n.ru/view/396001.html

2. О защите населения и территорий от чрезвычайных ситуаций природного и техногенного характера [Электронный ресурс]: Федеральный закон от 21.12.1994 № 68-Ф3 (ред. от 03.07.2019). URL: https://base.garant. ru/10107960/ (дата обращения: 29.11.2019).

3. О классификации чрезвычайных ситуаций природного и техногенного характера [Электронный ресурс]: Постановление Правительства РФ от 21.05.2007 № 304 (ред. от 17.05.2011). URL: https://base.garant.ru/12153609/ (дата обращения: 29.11.2019).

4. О безопасности гидротехнических сооружений [Электронный ресурс]: Федеральный закон от 21.07 .1997 № 117-Ф3 (ред. от 29.07.2018). URL: https://base.garant.ru/12100061/ (дата обращения: 29.11.2019).

5. О фредеральном государственном надзоре в области безопасности гидротехнических сооружений [Электронный ресурс]: Постановление Правительства РФ от 27.10.2012 № 1108 (ред. от 04.08.2017). URL: https://base. garant.ru/70250182/ (дата обращения: 29.11.2019).

6. О промышленной безопасности опасных производственных объектов [Электронный ресурс]: Федеральный закон от 21.07.1997 № 116-Ф3 (ред. от 29.07.2018). URL: https://base.garant.ru/11900785/ (дата обращения: 29.11.2019)

7. О единой государственной системе предупреждения и ликвидации чрезвычайных ситуаций [Электронный ресурс]: Постановление Правительства РФ от 30.12.2003 № 794 (ред. от 29.11.2018). URL: https://base.garant. ru/186620/ (дата обращения: 29.11.2019). 
8. Методические рекомендации по анализу, описанию и изучению действий органов управления, сил и средств РСЧС по ликвидации чрезвычайных ситуаций природного и техногенного характера (утв. МЧС России 10.07.2012 N 2-4-87-14-28) [Электронный ресурc]:URL: http://www.consultant.ru/cons/cgi/online.cgi?req=doc\&bas e=EXP\&n=523597\#0030812609294966098 (дата обращения: 29.11.2019)

9. О пожарной безопасности [Электронный ресурс]: Федеральный закон от 21.12.1994 № 69-Ф3 (ред. от 26.07.2019). URL: https://base.garant.ru/10103955/ (дата обращения: 29.11.2019).

\section{REFERENCES}

1. In Kuzbass, two children fell into a burning hole with slag, one boy died . (2017, June 5). Retrieved from https://www. city-n.ru/view/396001.html. [In Russian].

2. On the protection of the population and territories from natural and man-made emergencies. Federal Law of December 21, 1994 No. 68-FZ. (n.d.). Retrieved November 29, 2019, from https://base.garant.ru/10107960/. [In Russian].

3. On the classification of natural and man-made emergencies [Electronic resource]: Decree of the Government of the Russian Federation of 05.21.2007 No. 304 (as amended on 05/17/2011). (n.d.). Retrieved November 29, 2019, from https://base.garant.ru/12153609/ [In Russian].

4. On the safety of hydraulic structures.Federal law dated July 21, 1997 No. 117-FZ (as amended on July 29, 2018). (n.d.). Retrieved November 29, 2019, from https://base.garant.ru/12100061/ [In Russian]

5. On federal state supervision in the field of safety of hydraulic structures. Decree of the Government of the Russian Federation of October 27, 2012 No. 1108 (as amended on August 4, 2017). (n.d.). Retrieved from https://base.garant. ru/70250182/ [In Russian].

6. On the industrial safety of hazardous industrial facilities. Federal law of July 21, 1997 No. 116-FZ (as amended on July 29, 2018). (n.d.). Retrieved November 29, 2019, from https://base.garant.ru/11900785/ [In Russian].

7. On the Unified State System for the Prevention and Liquidation of Emergencies. Decree of the Government of the Russian Federation dated December 30, 2003 No. 794 (as amended on November 29, 2018). Retrieved November 29, 2019, from https://base.garant.ru/186620/ [In Russian]

8. Guidelines for the analysis, description and study of the actions of the management bodies, forces and assets of the Emergency Response System in response to natural and man-made emergencies (approved by EMERCOM of Russia 10.07.2012 N 2-4-87-14-28) Retrieved November 29, 2019, from http://www.consultant.ru/cons/cgi/online.cgi? req $=$ doc\&base $=E X P \& n=523597 \# 0030812609294966098$ [In Russian].

9. On fire safety. Federal law of December 21, 1994 No. 69-FZ (as amended on July 26, 2019). Retrieved November 29, 2019, from https://base.garant.ru/10103955/ [In Russian]

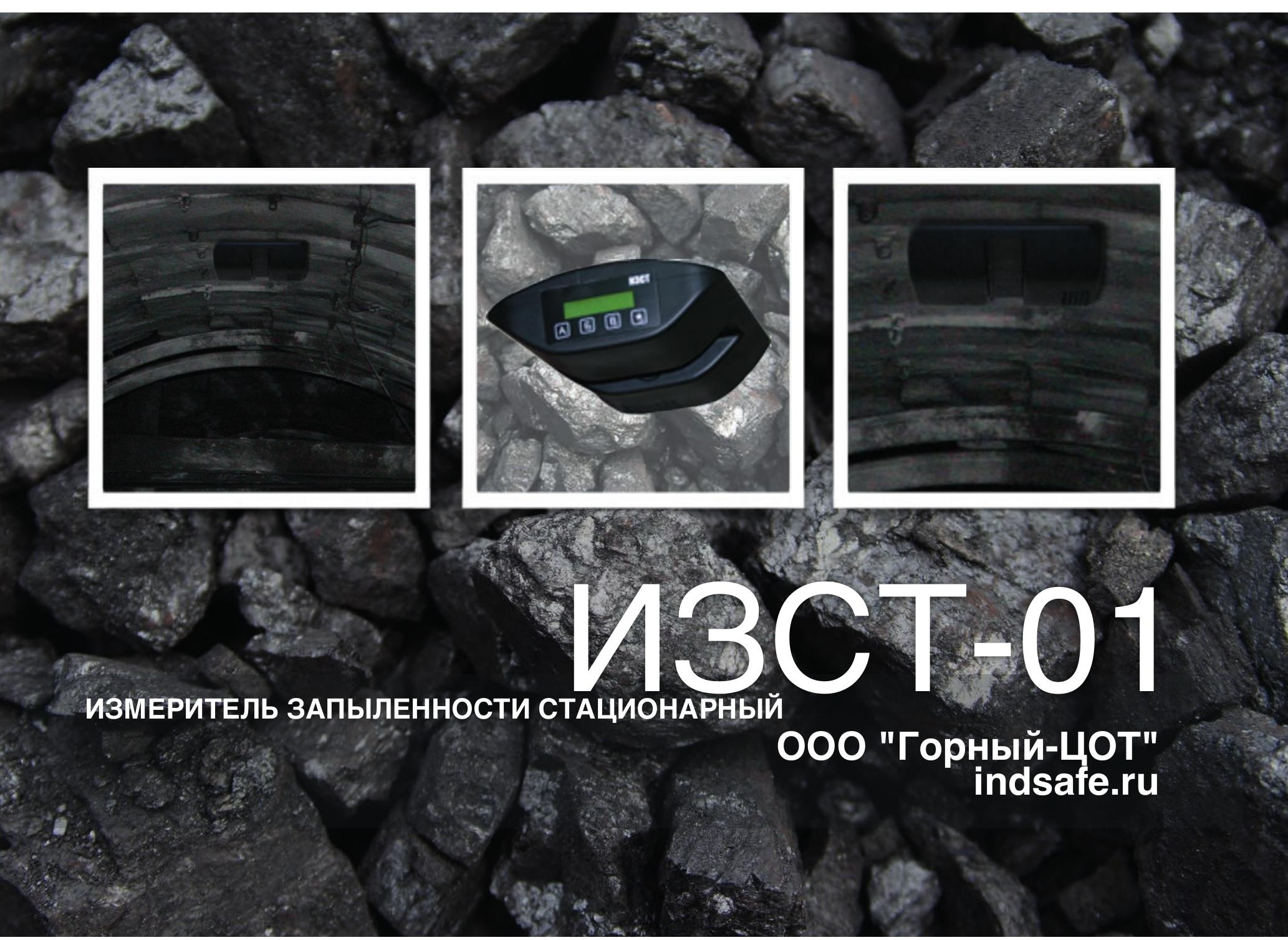




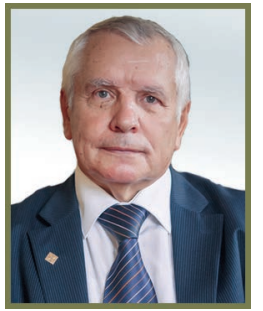

А. И. Фомин // А. I. Fomin ncvostnii@yandex.ru

д-р техн. наук, ведущий научный сотрудник отдела АО "НЦ ВостНИИ", Россия, 650002 , г. Кемерово, ул. Институтская, 3 doctor of technical sciences, department leading scientific researcher, JSC «ScC VostNII», 3, Institutskaya Str., Kemerovo, 650002, Russia

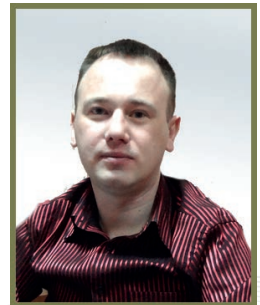

Д.А. Бесперстов//

D.A. Besperstov gpnbesperstov@yandex.ru

аспирант ФГБОУ ВО «КемГУ», Россия, 650056,. г. Кемерово, б-р Строителей, д 47 , корпус 7.

postgraduate of FGBOU VO "KemSU", Stroiteley Ave., 47 - 7, Kemerovo, 650056, Russia

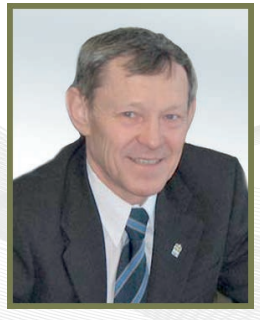

В.В. Соболев // V.V.Sobolev sobolev567@gmail.com доктор техн. наук, заместитель генерального директора АО «НЦ ВостНИИ», Россия, 650002, г. Кемерово, ул. Институтская, 3 Doctor of technical sciences, deputy general director of JSC «ScC VostNII» 3, Institutskaia St., Kemerovo, 650002, Russia

УДК 622;331.45;331.461

\title{
МЕТОДИКА ПРОГНОЗА УРОВНЯ ОХРАНЫ ТРУДА И
} БЕЗОПАСНОСТИ РАБОТНИКОВ УГОЛЬНОЙ ПРОМЫШЛЕННОСТИ НА ОСНОВЕ ПРОГНОЗА УПРАВЛЕНИЯ ПРОИЗВОДСТВЕННЫМИ РИ-

\section{СКАМИ}

\author{
OCCUPATIONAL HEALTH AND COAL INDUSTRY
}

\author{
WORKERS SAFETY LEVEL FORECASTING METHODS BASED \\ ON THE PRODUCTION RISK MANAGEMENT FORECAST
}

В статье изложена система обеспечения безопасности работников предприятий угольной промышленности на основе прогноза управления производственными рисками с иелью предотвращенияпроявленийопасныхпроизводственныхфакторовнарабочихместах, травмирования и гибели персонала предприятий по добыче и переработке угля. Рассмотрены статистический и потенциальный риски возникновения производственных ситуаций, связанных с проявлением опасных производственных фракторов, угрожающих нанесению вреда здоровью работникам. Приведены формулы расчета рисков на рабочих местах, а также методика, позволяющая связать мероприятия (систему обеспечения охраны труда и безопасности) с возможным и фактическим риском возникновения опасных производственных фракторов и гибели (травмирования) работников на них. Данная методика проста в применении и может быть использована как собственниками предприятий по добыче и переработке угля, так и органами государственного контроля и надзора.

The article describes the system of coal industry employees' safety provision on production risks management forecast basis in order to prevent hazardous production factor manifestations at the workplace, coal extraction and processing enterprises personnel injury and death. The statistical and potential risks of industrial situations associated with the manifestation of hazardous production factors that threaten to harm the health of employees are considered. The formulas for calculating the risks at the workplace, as well as a technique that allows to connect these measures (labor protection and safety provision system) with the possible and the actual risk of occupational hazards and death (injuries) to the workers there. This technique is easy to use and can be used both by the owners of enterprises for the extraction and processing of coal, and by the state control and supervision bodies.

КлючевЫе слова: УГОЛЬНАЯ ПРОМЫШЛЕННОСТЬ, ОХРАНА ТРУДА, УРОВЕНЬ БЕЗОПАСНОСТИ, ПРОГНОЗ СОСТОЯНИЯ ОХРАНЫ ТРУДА, УПРАВЛЕНИЕ ПРОИЗВОДСТВЕННЫМИ РИСКАМИ

Key words: COAL INDUSTRY, LABOR PROTECTION, SAFETY LEVEL, LABOUR PROTECTION CONDITION FORECAST, PRODUCTION RISKS MANAGEMENT 


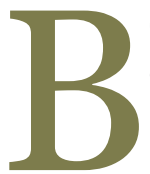
соответствии с нормативно-правовыми актами Российской Федерации порядок реализации методики по достижению необходимого уровня безопасности персонала и объектов угольной промышленности представлен в виде схемы (рис. 1.)

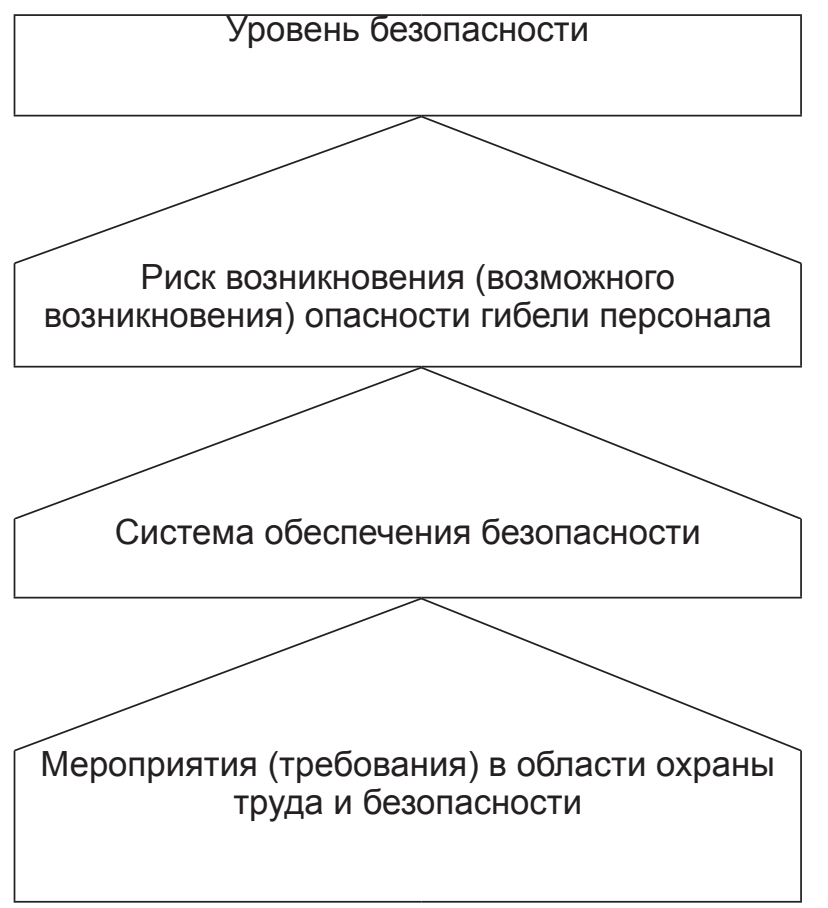

Рисунок 1 - Схема реализации методики по достижению

необходимого уровня безопасности работников

Figure 1 - Methods implementation scheme to achieve the employee safety required level

Требованиями (мероприятиями) безопасности являются специальные условия социального и (или) технического характера, установленные в целях обеспечения охраны труда и безопасности законодательством Российской Федерации, нормативными документами или уполномоченным государственным органом [1].

Система обеспечения безопасности предприятий угольной промышленности включает в себя систему предотвращения производственных опасностей, систему защиты и комплекс организационно-технических мероприятий. Для различных систем обеспечения охраны труда и безопасности применимы соответствующие требования безопасности.

Под риском R понимается количественная характеристика опасности, определяемая частотой реализации опасностей. Это отношение числа неблагоприятных последствий (количество возникших неблагоприятных производственных факторов на объектах защиты, гибели или травмирования работников), вызванных действием на персонал конкретной опасности ( $N$, шт., чел.), к их возможному числу (количество объектов, работников) за определённый период $(Q$, шт., чел.) [2].

В свою очередь, система предотвращения опасных фракторов влияет на риск их возникновения $\left(R_{n}\right)$, а система защиты влияет на риск гибели (травмирования) работников $\left(R_{2}\right)$. Комплекс организационно-технических мероприятий влияет как на риск возникновения негативных производственных факторов, так и на риск гибели (травмирования) персонала.

С учетом общих понятий, можно выделить статистический (фактический) и потенциальный риск возникновения производственных ситуаций, связанных с опасными производственными факторами и гибели (травмирования) персонала.

Статистический (фактический) риск возникновения негативной производственной ситуации $R_{n \text { факт }}$ и гибели персонала $R_{\text {с факт }}$ можно представить в следующем виде:

$$
\mathrm{R}_{\text {п факт }}=\frac{\mathrm{N}_{\text {II }}}{\mathrm{Q}_{0}}
$$

где $N_{n}$ - количество негативных производственных ситуаций, шт; $Q_{o}$ - количество объектов, шт.

$$
\mathrm{R}_{\mathrm{r} \text { факт }}=\frac{\mathrm{N}_{\mathrm{p}}}{\mathrm{Q}_{\mathrm{p}}}
$$

где $N_{p}$ - количество погибших (травмированных) работников, чел; $Q_{p}$ - общее количество работников на объектах, чел.

Потенциальный риск возникновения негативной производственной ситуации $R_{n \text { потени }}$ и гибели работников $R_{\text {гпотени }}$ представлен следующем образом:

$$
\mathrm{R}_{\mathrm{n} \text { погени }}=\frac{\mathrm{N}_{\mathrm{omm}}}{\mathrm{Q}_{\mathrm{o}}}
$$

где $N_{o n n}$ - количество объектов, с отсутствующей (неисправной) системой предотвращения негативных производственных факторов и (или) комплексом организационно-технические мероприятия, шт; $Q_{o}$ - количество объектов, шт.

$$
\mathrm{R}_{\mathrm{r} \text { погенц }}=\frac{\mathrm{N}_{\mathrm{p} \text { пз }}}{\mathrm{Q}_{\mathrm{p}}}
$$

где $N_{p n s}$ - количество работников на объектах, с отсутствующей (неисправной) системой производственной защиты и (или) комплексом организационно-технических мероприятий, шт; $Q_{p}$ общее количество работников на угольных предприятиях, чел.

Риск - сочетание возможности и последствий наступления неблагоприятных событий. Знание вероятности неблагоприятного события 
позволяет определить вероятность благоприятных событий по формуле $P_{+}=1-P$.

В свою очередь, вероятность - степень (относительная мера, количественная оценка) возможности наступления некоторого неблагоприятного события [3].

В теории вероятности и математической статистики понятие вероятности формализуется как числовая характеристика события - вероятностная мера (или её значение) на множестве событий (подмножеств множества элементарных событий), принимающая значения от 0 до 1. Значение 1 соответствует достоверному событию. Невозможное событие имеет вероятность 0 . Если вероятность наступления события равна $p$, то вероятность его не наступления равна $1-p$ [4].

Уровень безопасности по мероприятиям, направленным на предупреждение возникновения опасных производственных фракторов, принимает значения от 1 до 0, где 1 - уровень безопасности объекта соответствует предъявляемым требованиям.

Уровень безопасности по мероприятиям, направленным на предупреждение гибели (травмирования) персонала, принимает значения от $10^{-6}$ до 0, где $10^{-6}$ - уровень безопасности людей соответствует предъявляемым требованиям [5].

Значение уровня обеспечения охраны тру- да и безопасности людей отличается от объекта, так как допустимое нормативное значение риска гибели персонала составляет $10^{-6}$ в год [5].

С учетом вышеизложенного можно сделать следующие выводы по оценке соответствия объекта требованиям безопасности при их загорании.

При условии $R_{n \text { потени }}>R_{n \text { фактич }}$ мероприятия по обеспечению безопасности выполняются, имеющиеся нарушения требований по обеспечению безопасности не влияют (малозначительно влияют) на состояние объекта. Если $R_{n \text { потени }}$ $<R_{n \text { фактич }}$ - мероприятия по обеспечению безопасности не выполняются, имеющиеся нарушения требований безопасности на предприятии отрицательно влияют на безопасное состояние объекта.

В свою очередь, при условии $10^{-6}>R_{\text {г потени }}$ $>R_{\text {г фактич }}$ мероприятия по обеспечению безопасности работников выполняются, имеющиеся нарушения, направленные на обеспечение безопасности персонала, влияют на их безопасность, на приемлемом уровне. В случае, если $10^{-6}<R_{\text {г потени }}<R_{\text {г фактич }}$, мероприятия по обеспечению безопасности работников не выполняются, имеющиеся нарушения отрицательно влияют на безопасность персонала.

Как мы видим, приведенная методика позволила связать мероприятия (систему обе-

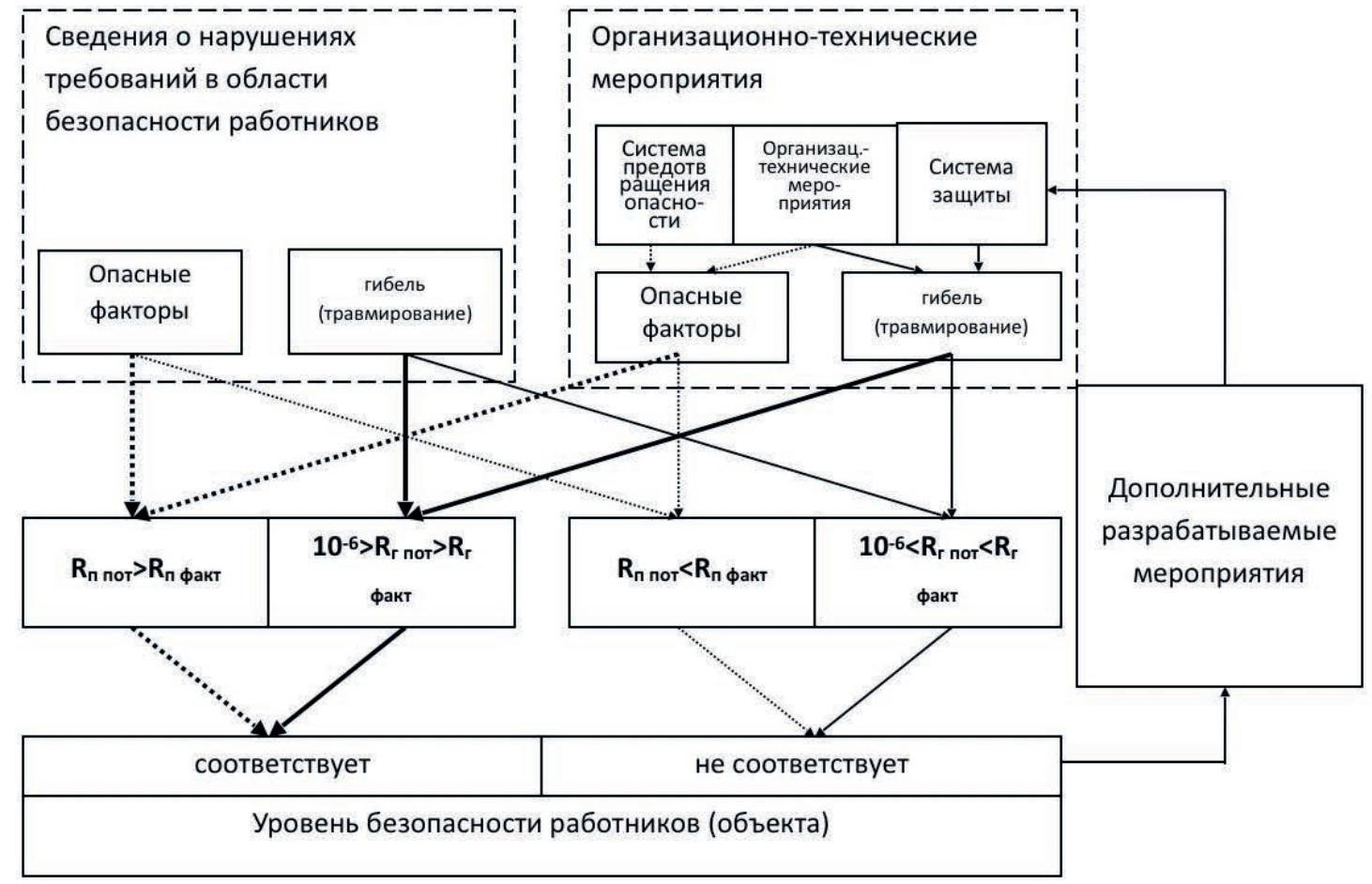

Рисунок 2. - Схема реализации необходимого уровня безопасности, с учетом потенциального и фрактического риска возникновения опасных производственных фракторов, гибели (травмирования)

Figure 2. - The required safety level implementation scheme with the potential and actual risk of hazardous industrial factors, death (injury) account 
спечения охраны труда и безопасности) с возможным и фактическим риском возникновения опасных производственных факторов и гибели (травмирования) работников на них.

Применение данной методики оценки уровня безопасности на объекте возможно не только для их собственников, но и для органов, осуществляющих оценку соответствия объекта установленным требованиям в области охраны труда и безопасности, в том числе для органов государственного надзора. Для данных структур появилась возможность планирования проверок объектов с учетом статистических (фактических) рисков возникновения опасных производственных факторов и гибели работников с последующей оценкой своих действий в отношении данных объектов, сопоставляя возможные (потенциальные) риски со статистическими (фактическими). Также данная методика проста в применении, в ней отсутствуют сложные математические расчеты, требуется минимальное количество необходимых данных.

С учетом вышеизложенного, ранее представленную схему на рис.1 можно представить в виде схемы (рис. 2).

Апробация методики прогнозирования оценки уровня охраны труда и безопасности работников, находящихся на предприятиях угольной отрасли

С учетом данных официального статистического учета негативных производственных фракторов, связанных с загораниями и их последствий, произошедших на угольных предприятиях Кемеровской области за 2017 год, сведений о количестве объектов Кузбасса, в отношении которых осуществляется фредеральный государственный надзор, и сведений по применению административного законодательства по объектам надзора за 2017 год для наглядности рассмотрим оценку уровня безопасности объектов, рассматриваемого функционального назначения.

За 2017 год надзорными органами Кемеровской области проведена оценка на соответствие требованиям безопасности 195 объектов угольных предприятий. При оценках установлено, что в 96 зданиях и сооружениях выявлены нарушения требований в области охраны труда и безопасности в части недостаточности систем предотвращения опасных производственных факторов, защиты и невыполнения комплекса организационно-технических мероприятий.

За 2017 год на территории Кемеровской области произошло 8 ситуаций, которые привели к загораниям на объектах угольной промышленности Кузбасса, что составляет 15,4 \% от общего количества подобных ситуаций, произошедших на рассматриваемых предприятиях производственного назначения. На данных объектах гибель и травмирование работников не допущено.

Статистический (фактический) риск возникновения опасных производственных фракторов $R_{\text {п факт }}$ и гибели персонала $R_{\text {с факт }}$ в зданиях и сооружениях угольных предприятий Кемеровской области рассчитывается следующим образом:

$$
\mathrm{R}_{\text {п факт }}=\frac{\mathrm{N}_{\text {пI }}}{\mathrm{Q}_{\mathrm{o}}}=\frac{8}{195}=4,1 \cdot 10^{-2},
$$

где $N_{\text {п }}$ - количество ситуаций, которые привели к загораниям, возникших в зданиях и сооружениях угольной промышленности Кемеровской области за 2017 год; $Q_{o}$ - количество зданий угольной промышленности, расположенных на территории Кемеровской области

$$
\mathrm{R}_{\mathrm{r} \text { факт }}=\frac{\mathrm{N}_{\mathrm{p}}}{\mathrm{Q}_{\mathrm{p}}}=\frac{0(0)}{12500}=0(0)
$$

где $N_{\mathrm{p}}$ - количество погибших (травмированных) работников при опасных производственных фракторах, связанных с загораниями, возникшими в зданиях и сооружениях предприятий угледобывающей и углеперерабатывающей промышленности Кемеровской области за 2017 год; $Q_{\mathrm{p}}$ - общее количество работников в зданиях и сооружениях угольных предприятий, расположенных на территории Кемеровской области.

Возможный (потенциальный) риск возникновения опасных производственных фракторов, связанных с загораниями $R_{\text {пптенц }}$ и гибелью людей $R_{\text {г потен }}$ В зданиях и сооружениях угольных предприятий Кемеровской области рассчитывается следующим образом:

$$
\mathrm{R}_{\text {п потенц }}=\frac{\mathrm{N}_{\mathrm{omm}}}{\mathrm{Q}_{\mathrm{o}}}=\frac{78}{195}=4,0 \cdot 10^{-1}
$$

где $N_{o n n}$ - количество зданий с отсутствующими (неисправными) системами предотвращения негативных производственных ситуаций, а также комплексом организационно-технических мероприятий; $Q_{o}$ - количество зданий угольных предприятий, расположенных на территории Кемеровской области.

$$
\mathrm{R}_{\text {г потенц }}=\frac{\mathrm{N}_{\mathrm{p} \mathrm{n}_{3}}}{\mathrm{Q}_{\mathrm{p}}}=\frac{7488}{12500}=6,0 \cdot 10^{-1}
$$

где $N_{\text {рпз }}$ - количество работников в рассматриваемых зданиях, с отсутствующими (неисправными) системами защиты персонала и комплексом организационно-технических мероприятий; $Q_{\text {p }}$ - общее количество работников, находящихся в 
зданиях угольных предприятий Кемеровской области.

Выводы по оценке в области охраны труда и безопасности производственных зданий.

В результате проведенных расчетов установлено, что $R_{\text {п факт }}\left(4,1 \cdot 10^{-2}\right)<R_{\text {п потенц }}\left(4,0 \cdot 10^{-1}\right)$, из чего следует, что мероприятия по обеспечению охраны труда и безопасности объектов угольной промышленности Кузбасса выполняются. Оценка соответствия по обеспечению безопасности объекта проведена правильно.

Вместе с этим $R_{\text {г факт }}(0(0))<10^{-6}<R_{\text {г потенц }}$ $\left(6,0 \cdot 10^{-1}\right)$, из чего следует, что мероприятия по обеспечению охраны труда и безопасности персонала выполняются, но не в полном объеме, так как величина потенциального риска гибели

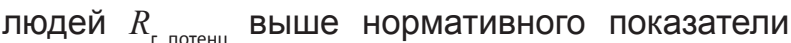
допустимого риска гибели людей $\left(10^{-6}\right)$. Необходима разработка дополнительных мероприятий системы защиты, направленных на обеспечение охраны труда и безопасности персонала угольных предприятий Кемеровской области [6, 7, 8].

\section{Выводы}

1. Изложена методика качественной оценки обеспечения охраны труда и безопасности на объектах с учетом их функциональной опасности, с помощью которой произведена оценка охраны труда и безопасности объектов, а также персонала предприятий угольной промышленности Кемеровской области, получены количественные характеристики объектов и их опасностей приведены в относительных качественных показателях.

2. Введены понятия статистических (фактических) и возможных (потенциальных) рисков возникновения опасных производственных факторов и гибели (травмирования) людей на них.

3. Методика рекомендована для использования органами, осуществляющими оценку соответствия зданий и сооружений угольных предприятий, установленным требованиям в области обеспечения охраны труда и безопасности, с учетом соблюдения и выполнения организационно-технических мероприятий по защите и сохранению жизни и здоровья работников.

\section{СПИСОК ЛИТЕРАТУРЫ}

1. Фомин А.И., Бесперстов Д.А. Обеспечение пожаробезопасности угольных предприятий Кузбасса в современных условиях // Обеспечение безопасности жизнедеятельности: проблемы и перспективы: Сб. материалов IX международной научно-практической конференции молодых ученых: курсантов (студентов), слушателей магистратуры и адъюнктов (аспирантов): в 2-х ч. Ч. 1. Минск: КИИ, 2015. 143 с.

2. Фомин А.И., Бесперстов Д.А. Актуальность разработки и совершенствования способа повышения безопасности работников на угледобывающих и углеперерабатывающих предприятиях Кузбасса // Вестник научного центра по безопасности работ в угольной промышленности. 2015. № 1. С. 62-66.

3. Гнеденко Б.В. Курс теории вероятности. М., 2007. 42 с.

4. Фомин А.И., Бесперстов Д.А. Повышение пожарной безопасности работников угольной отрасли Кузбасса // Сборник Материалов Всероссийской научно-практической конференции «Фундаментальные и прикладные проблемы в горном деле (Междуреченск, 25 фревраля 2016 г.). С. 65-66.

5. Технический регламент о требованиях пожарной безопасности [Электронный ресурс]: Федер. закон от 22.07.2008 № 123-Ф3 (ред. от 03.07.2016). URL: http://www.consultant.ru/document/cons doc LAW 78699 (дата обращения: 04.09.2018).

6. Фомин А.И., Бесперстов Д.А., Попов В.Б. Оценка уровня пожарной безопасности на угольных предприятиях с учетом риск-ориентированного подхода // Вестник научного центра по безопасности работ в угольной промышленности. 2016. № 1. С. 62-66.

7. Об утверждении статистического инструментария для организации МЧС России фредерального статистического наблюдения за пожарами и последствиями от них [Электронный ресурс]: Приказ Росстата от 23.12.2009 № 311 URL: http://www.consultant.ru/document/cons_doc_LAW_95826/ (дата обращения: 04.09.2018).

8. Фомин А.И., Бесперстов Д.А. Методика оценки пожарной безопасности объектов // Фундаментальные и прикладные проблемы в горном деле: Материалы Всероссийской научно-практической конференции (Филиал КузГТУ в г. Междуреченске, 25 фревраля 2016 г.). Междуреченск: Кузбасский государственный технический университет, 2016. - С 55-63.

\section{REFERENCES}

1. Fomin, A.I., \& Besperstov, D.A. (2015). Obespechenie pozharobezopasnosti ugolnykh predpriyatii Kuzbassa v sovremennykh usloviiakh [Kuzbass coal enterprises fire safety provision in modern conditions]. Processing from Life Safety: Problems and Prospects: IX Mezhdunarodnaia nauchno-ptakticheskaia konferentsiia molodykh uchenykh: kursantov (studentov), slushatelei magistratury i adiunktov (aspirantov) - IX international scientific-practical conference of young scientists: cadets (students), graduate students and adjuncts (graduate students), part 1. Minsk:KII [in Russian].

2. Fomin, A.I. \& Besperstov, D.A. (2015). Aktualnost razrabotki i sovershenstvovaniia sposoba povysheniia bezopasnosti rabotnikov na ugledobyvaiushchikh i uglepererabatyvaiushchikh predpriiatiyakh Kuzbassa [The relevance of the development and improvement of ways to improve the safety of workers in coal mining and coal processing enterprises of Kuzbass]. Vestnik nauchnogo tsentra po bezopasnosti rabotv ugolnoi promyshlennosti - Herald of Safety in Mining Industry Scientific Center, 1, 62-66 [in Russian].

3. Gnedenko, B.V. (2007). Kurs teorii veroiatnosti [Course of probability theory]. Moscow: [in Russian]. 
4. Fomin, A.I. \& Besperstov, D.A. (2016). Povyshenie pozharnoi bezopasnosti rabotnikov ugolnoi otrasli Kuzbassa [Kuzbass coal industry workers fire safety improvement]. Proceedings from Fundamental and applied problems in mining: Vserossiiskaia nauchno-prakticheskaia konferentsiia (25 fevralia 2016 goda) - All-Russian Scientific and Practical Conference (pp.65-66). Mezhdurechensk [in Russian].

5. Tekhnicheskij reglament o trebovaniyah pozharnoj bezopasnosti [EHlektronnyj resurs]: Feder. zakon ot 22.07.2008 № 123-FZ (red. ot 03.07.2016) [Technical regulations on fire safety requirements [Electronic resource]: the Federal law of July 22, 2008 No. 123-ФZ (as amended on July 03, 2016)]. Retrieved from: http://www.consultant.ru/document/cons doc_LAW_78699 [in Russian]

6. Fomin, A.I., Besperstov, D.A., \& Popov, V.B. (2016). Otsenka urovnia pozharnoi bezopasnosti na ugolnykh predpriiatiiakh s uchetom risk-orientirovannogo podhoda [Coal enterprises fire safety level assessment with a risk-based approach]. Vestnik nauchnogo tsentra po bezopasnosti rabot v ugolnoi promyshlennosti - Herald of Safety in Mining Industry Scientific Center, 1, 62-66 [in Russian].

7. Ob utverzhdenii statisticheskogo instrumentariia dlia organizacii MCHS Rossii federalnogo statisticheskogo nabliudeniia za pozharami i posledstviiami ot nih [On the approval of statistical tools for federal statistical monitoring of fires and their consequences organizing by the Federal Emergencies Ministry]. Rosstat Order of December 23, 2009. Retrieved from: : http://www.consultant.ru /document/cons_doc_LAW_95826/ [in Russian].

8. Fomin, A.I. \& Besperstov, D.A. (2016). Metodika otsenki pozharnoi bezopasnosti obiektov [Methods for assessing the facilities fire safety]. Proceedings from Fundamental and applied problems in mining: Vserossiiskaia nauchnoprakticheskaia konferentsiia (25 fevralia 2016 goda) - All-Russian Scientific and Practical Conference (pp.55-63). Mezhdurechensk: Kuzbass State Technical University [in Russian]

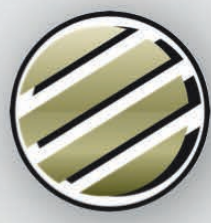

о Вывод данных с датчиков при помощи собственной цифровой платформы DustGas в режиме онлайн на сайт компании или в системы диспетчерских

о Сигнал при превышении ПДК или установленных показателей измерений

о Беспроводная передача данных с датчиков

о Прозрачная API для сторонних разработчиков ПО и датчиков

о По сигналу датчика включается система пылеподавления

о Анализируется скорость ветра и направления для принятия решения о включения нужного блока ПГО

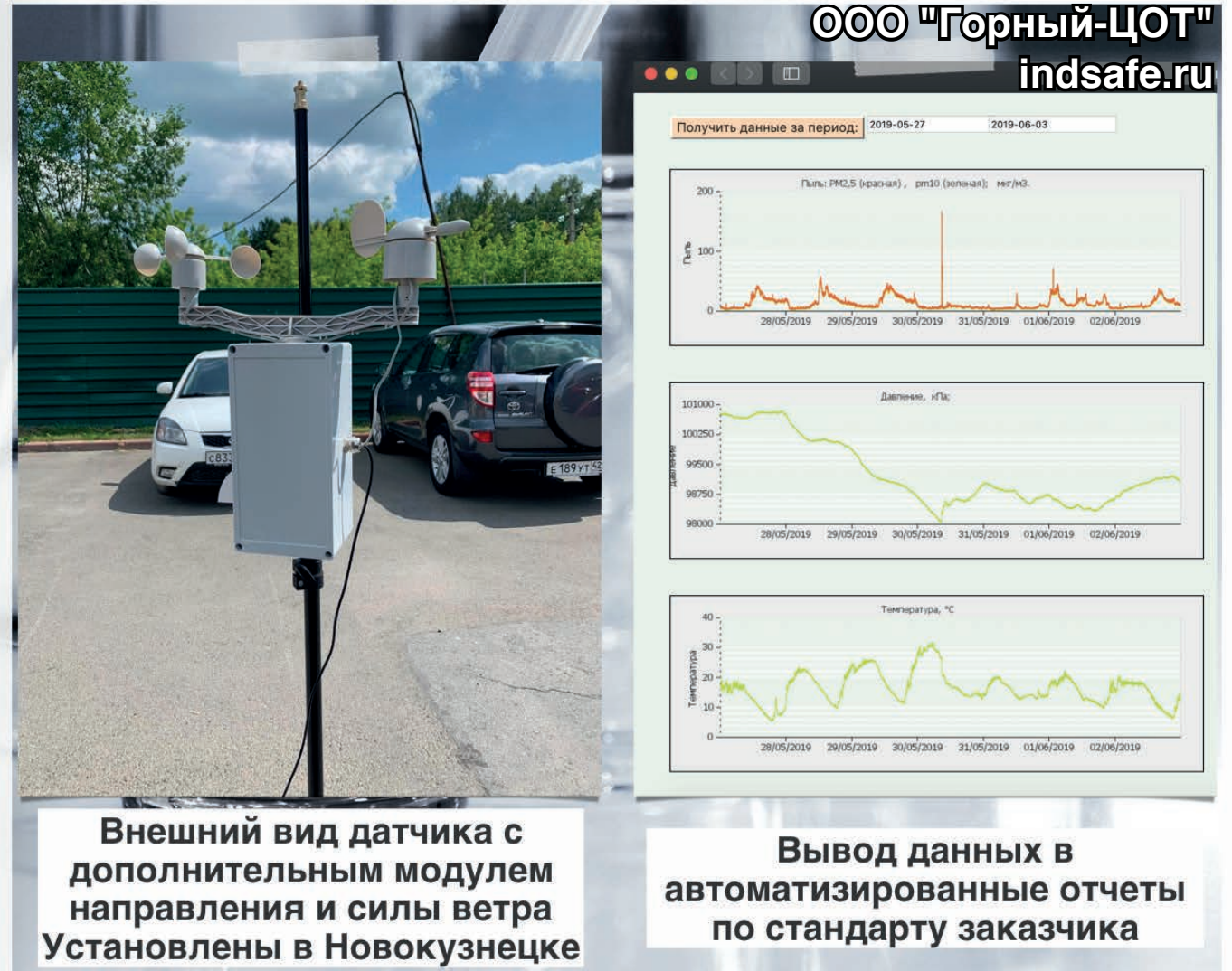




\section{III. ТЕХНОЛОГИЧЕСКИЕ ВОПРОСЫ БЕЗОПАСНОСТИ ГОРНЫХ РАБОТ III. TECHNOLOGICAL QUESTIONS OF MINING WORK SAFETY}

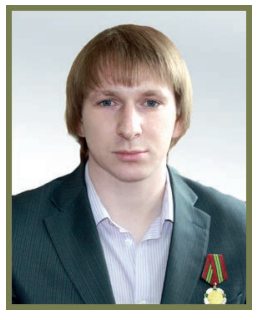

P.И. Родин // R.I. Rodin rodinri@mail.ru

научный сотрудник, Институт угля Федерального исследовательского центра угля и углехимии Сибирского отделения Российской академии наук (ИУ ФИЦ УУХ СО РАН), Россия, 650065 г. Кемерово, проспект Ленинградский,

scientific researcher, Institute of Coal, Coal and Coal Chemistry Federal Research Center, Russian Academy of Sciences Siberian Branch (IU FIC UUKh SB RAS); Russia, 650065, Kemerovo, Leningradsky Av.

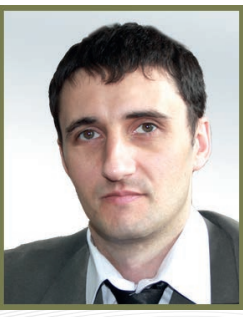

М.В. Шинкевич// Shinkevich M.V.357@mail.ru

канд техн. наук, старший научный сотрудник, Институт угля Федерального исследовательского центра угля и углехимии Сибирского отделения Российской академии наук (ИУ ФИЦ УУХ СО РАН), Россия, 650065 г Кемерово, проспект Ленинградский, 10 candidate of technical sciences, chief scientific researcher, Institute of Coal, Coal and Coal Chemistry Federal

Research Center, Russian Academy of Sciences Siberian Branch (IU FIC UUKh SB RAS); Russia, 650065, Kemerovo, Leningradsky Av., 10

Удк 622.831.325.3

\section{ОЦЕНКА ЭФФЕКТИВНОСТИ ПЛАСТОВОЙ ДЕГАЗАЦИИ НА ОСНОВЕ СТАТИСТИЧЕСКОГО АНАЛИЗА ДЕБИТА ДЕГАЗАЦИОННЫХ СКВАЖИН SEAM DEGASSING EFFICIENCY ESTIMATION BASED ON DEGASSING BOREHOLES OUTPUT STATISTICAL ANALYSIS}

В статье приведен статистический анализ данных о дебите пластовых дегазационных скважин одного из выемочных участков и определена зависимость параметров дегазации угольного пласта от процессов сдвижений горных пород, их воздействия на пласт угля при ведении очистных работ. Для оценки эффрективности дегазации на выемочном участке использовались фрактические данные мониторинга дебита скважин пластовой дегазации, которые фиксировались в журнале учета работы дегазационных скважин. Проанализированы данные дебита метана 79 одиночных параллельных забою дегазационных скважин, пробуренных с конвейерного штрека по восстанию угольного пласта. Определено, что более эфрфективно бурение дегазационных скважин большего диаметра. Проведено сравнение дебита скважин предварительной дегазации и текущей, проводимой одновременно с ведением работ по добыче угля. Зарегистрированы особенности изменения продуктивности скважин. Отмечается эфрфект разгрузки, опережающей длинный очистной забой при его движении, что увеличивает выделение метана в дегазационные скважины, находящиеся в этой зоне. Определено, что количество извлекаемого системой дегазации метана из угольного пласта выше в полтора раза при ведении очистных работ, чем при предварительной дегазации. Именно при текущей дегазации пласта угля возможно снижение его газоносности до нормативной величины. Отмечена справедливость известной модели изменения газоносности пласта и отбитого угля во времени и обоснована правомерность ее дополнения с учетом геомеханических процессов. Даны рекомендации по повышению эффрективности пластовой дегазации выемочного участка за счет использования влияния геомеханических процессов при движении длинного очистного забоя.

The article provides data statistical analysis of seam degassing boreholes output of one of the extraction sections and determines the coal seam degassing parameters dependence on the processes of rock movements, their impact on the coal seam during extraction works. To assess the effectiveness of degassing at the extraction section, the actual monitoring data of the seam degassing boreholes output were used, which were recorded in the degassing boreholes operation logbook. The methane output data of 79 single degassing boreholes parallel to the face, drilled from a conveyor drift along a coal seam uprising, are analyzed. It was determined that drilling of larger diameter degassing boreholes is more efficient. A comparison is made of pre- 
liminary degassing boreholes output and of the current one, carried out simultaneously with coal mining. The change features in borehole productivity are recorded. An unloading effect that is ahead of the long extraction face during its movement is noted, which increases the methane emission to the degassing boreholes located in this zone. It was determined that the amount of methane extracted from the coal seam by the degassing system is one and a half times higher during extraction operations than during preliminary degassing. It is exactly with the coal seam current degassing that becomes possible to reduce its gas content to a standard value. The well-known model of the seam and crushed coal gas content changing in time validity is noted, and the legitimacy of its addition is justified taking into account geomechanical processes. Recommendations are given on increasing the efficiency of an extraction section seam degassing through the use of geomechanical processes influence during a long extraction face advance.

КЛючевЫе слова: УГОЛЬНЫЙ ПЛАСТ, ВЫСОКОПРОИЗВОДИТЕЛЬНЫЙ ВЫЕМОЧНЫЙ УЧАСТОК, ВЫЕМКА УГОЛЬНОГО ПЛАСТА, ДЕГАЗАЦИЯ, СДВИЖЕНИЯ, ГЕОМЕХАНИКА

Key words: COAL SEAM, HIGH PRODUCTION EXTRACTION SECTION, COAL SEAM EXTRACTION, DEGASSING, MOVEMENT, GEOMECHANICS

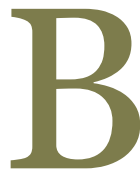

\section{ведение}

Добыча угля вызывает метановыделение при разрушении угольного пласта и разгрузку массива горных пород при выемке угля. Современные технологии добычи угля подразумевают выемочные столбы большой площади и высокие скорости подвигания очистных забоев-десятки метров в сутки, при этом отбивается и транспортируется значительная масса угля Предварительная дегазация пласта, повышение её эфрфективности в таких условиях очень актуальна. В настоящее время в угольной отрасли действуют нормативные документы [1, 2], разработанные в прошлом веке на основе широкомасштабных осреднений как горно-геологических, так и горнотехнологических факторов, которые в современных условиях недостаточно приспособлены к возросшей динамике метановыделения, прежде всего связанной с повышением нагрузок на забои и увеличением геометрических размеров выемочных столбов. Так же в существующих нормативных документах не учитывается все многообразие процессов сдвижений и их влияние на массив горных пород. В результате прогнозируемые значения метанообильности горных выработок имеют отклонения от фактических данных в несколько раз, это ставит новые вопросы о процессах, происходящих в массиве горных пород при проведении работ, решением которых занимаются многие научные организации как в России [3-10], так и за рубежом [11-13].

\section{Цели и задачи.}

Одним из путей решения сложных задач по управлению газовыделения является адекватная оценка метановыделения, уточнение знаний об особенностях геомеханических и, как следствие, газодинамических процессов во вмещающем массиве в зоне влияния горных работ.
Известен эфрфект опережающей разгрузки впереди двигающегося очистного забоя, что вызывает газоотдачу угольного пласта и рост продуктивности дегазационных скважин. Настоящие исследования позволят повысить эффективность дегазации угольного пласта.

\section{Методы.}

В качестве объекта исследования был выбран выемочный участок 3-32 шахты Алардинская (г. Осинники), отрабатывающий месторождение угольного пласта 3-3а (рис.1). Длина очистной выработки на большой части исследуемого участка 220 м. Глубина ведения горных работ - 630 м. Длина исследуемого участка 1130 м. Протяженность всего выемочного участка 3-32 составляет 1950 м. Мощность вынимаемого угольного пласта 4,31 м. Природная газоносность пласта в среднем составляет 18,2 м³/т.

Для оценки эффрективности дегазации на выемочном участке 3-32 использовались фрактические данные мониторинга дебита скважин пластовой дегазации, которые фиксировались в журнале учета работы дегазационных скважин согласно приложению №22 к инструкции по дегазации угольных шахт [1]. Проанализированы данные дебита метана 79 одиночных параллельных забою дегазационных скважин, пробуренных с конвейерного штрека 3-32 по восстанию угольного пласта. Максимальное время работы исследуемых скважин составило 1412 суток (скв. № 1), минимальное - 212 сут. (скв.79). Максимальный средний дебит дегазационных скважин 78,6 м $3 /$ сутки, минимальный - 0,9 м³/сутки. На рис.2 представлена более детальная картина распределения удельного среднесуточного дебита по всем 79 скважинам с начала их работы до отключения от дегазационной магистрали.

В процессе анализа данных дебита дегазационных скважин исследуемый участок был 


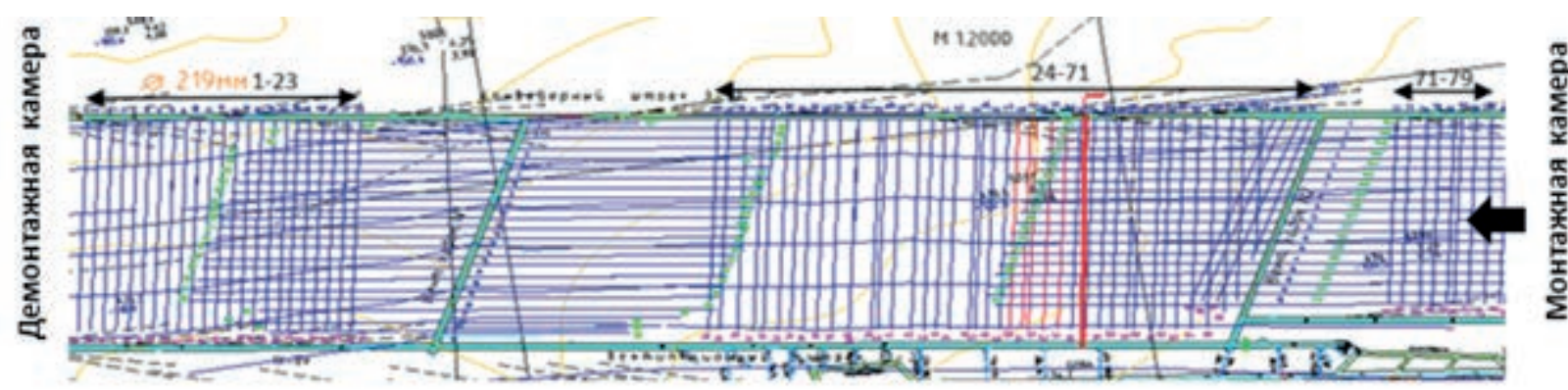

Рисунок 1 - Выкопировка с плана горных работ выемочного участка 3-32 с расположением дегазационных скважин

Figure 1 - Copy from the mining plan of extration section 3-32 with the location of degassing boreholes

условно разделен на три интервала, которые указаны на рис.1. Первый интервал расположен с 1 по 23 скважину с диаметром бурения 93 мм. Второй интервал расположен между 1-ым и 2-ым вентиляционными ходками и включает в себя скважины диаметром 93 мм с 24 скв. по 71 СКв.

Последний интервал включает в себя скважины с 72 по 79 с диаметром 76 мм. В данной работе не проводился анализ пластовых дегазационных скважин, пробуренных с бортов вентиляционных ходков по направлению к очистному забою выработки и у монтажной камеры. Хотя данные скважины также имеют существенное влияние как на итоговую дегазацию в целом, так и на продуктивность отдельно взятых скважин, которые пересекаются в горизонтальной плоскости.

Анализ итоговой продуктивности дегазационных мероприятий за все время фиксирования дебита скважин показал, что общий объем каптированного метана составил $1278845 \mathrm{~m}^{3}$ (21\% от общего объема метана, заключенного в угольном пласте оцениваемой области выемочного участка 3-32). Условно приняв отрабатываемый пласт единственным источником метана, можно заключить, что пластовая дегазация снизила природную газоносность пласта с 18,2 до 14,4 м $3 /$ т за весь период мониторинга дебита дегазационных скважин конвейерного штрека 3-32. Согласно нормативному документу, дегазация выемочного участка обязательно проводится, если природная газоносность выше $13 \mathrm{~m}^{3} /$ т. Однако эффеективность пластовой дегазации по длине выемочного участка неоднородна в виду объективного влияния нелинейно изменяющихся геомеханических процессов при движущемся очистном забое и, как следствие, газокинетических параметров углепородного массива в процессе проведения подготовительных и очистных работ. В результате дифференцированной оценки эфрфективности пластовой дегазации угольного пласта установлено, что на 1-ом интервале каптировано - 313271 м $^{3}$ метана (27\%), на 2-ом интервале - 952480 (37\%) и на 3-ем - 13094 (3,5\%). По фракту лишь на втором интервале скважины показали наибольшую эффективность и снизили газоносность пласта с $18,2 \mathrm{~m}^{3} /$ т до $11,5 \mathrm{~m}^{3} / \mathrm{T}$.

Очевиден тот фракт, что дегазационные скважины диаметром 76 мм имели низкую продуктивность. Вероятнее всего, данный факт связан с «затеканием» (пережим, завал, запрессовка угольной мелочью) скважин диаметром 76 мм в сложившихся геологических и горно-технологических условиях.

На момент выключения от дегазационной магистрали ближайшей к очистному забою скважины №79 (в 10 м от линии очистного забоя) продуктивность всех 79 скважин на тот момент (в режиме предварительной дегазации - 1048 суток с начала работы скважины №1) составила 835699 м $^{3}$ метана (65 \% от общего объема, извлеченного системой дегазации). Соответственно 443146 м $^{3}$ (35 \% от общего объема, извлеченного системой дегазации) метана было каптировано в режиме текущей дегазации за последующее 374 суток работы дегазационной системы участка, во время ведения добычных работ и движения очистного забоя, т.е. продуктивность работы скважин во время движения забоя увеличилась в 1,5 раза.

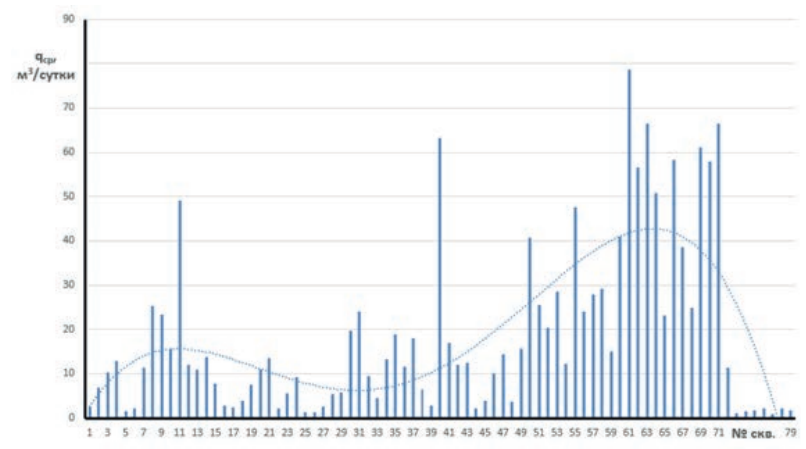

Рисунок 2 - Графрик продуктивности дегазационных скважин конвейерного штрека 3-32

Figure 2 - Graph of conveyor drift 3-32 degassing boreholes productivity 
Для более глубокого анализа эффективности пластовой дегазации установлен абсолютный дебит для типичной дегазационной скважины на 1-ом и 2-ом интервалах (рис. 3а, 3б). Интересен тот факт, что график изменения газовыделения из скважин в течение 180 суток не снижается, а увеличивается вопреки распространенным представлениям о снижающейся экспоненциальной зависимости данного процесса во времени. Такой эффект возможен в условиях максимальной зажатости угольной матрицы (низкой проницаемости пласта), когда за счёт бурения скважины происходит небольшая разгрузка массива с выделением небольшого количества метана. Выделение этого объема в свою очередь также приводит к газоистощению зоны вокруг скважины, последующей разгрузке массива и выделению еще большего объема газа. В сложившейся ситуации оптимальным могло быть решение о бурение скважин в два ряда, с целью более рационального использования эффекта разгрузки угольного массива и ускорения дегазации пласта.

Отдельным интересным вопросом является оценка влияния на продуктивность дегазационных скважин по мере приближения очистного забоя. Графики продуктивности большей части дегазационных скважин фииксируют резкий рост дебита метана при приближении к ним работающего забоя на расстояние 100120 метров, когда они начинают работать в зоне опережающей разгрузки. Лишь несколько скважин характеризуются изначально высокими значениями дебита метана и отсутствием всплеска газовыделения при приближении зоны разгрузки. Показательно, что данные скважины расположены в непосредственной близости от диагональной горной выработки в теле столба (вентиляционный ходок №2). Таким образом, характер процесса газовыделения в этих скважинах объясняется фрормированием зоны

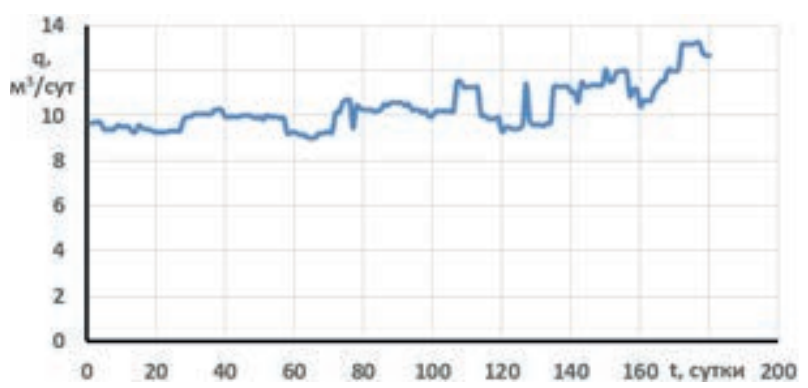

a) с 1 по 23

a) from 1 to 23 разгрузки за счет наличия подготовительной выработки.

Все вышесказанное хорошо согласуется с представленной в источнике [14] классической моделью (рис.3) изменения газоносности пласта, которую мы можем дополнить результатами настоящих исследований. Кроме того, модель отлично коррелируется с современным представлением о формах существования метана в угле [15]. Именно интенсивное выделение метана объясняется снижением или полным снятием геостатических напряжений в процессе отработки угольного пласта и запуском механизма распада твердого углегазового раствора. Возможно, что в случае с дегазационными скважинами с диаметром 76 мм разгрузка пласта была незначительна для запуска описанного выше механизма реализации газового потенциала пласта (скважина №72, располагающаяся в зоне влияния разгрузки от пройденного вентиляционного ходка №2, показала удовлетворительную эфрфективность). В модели интервал времени $\mathrm{t}_{1}$ характеризует снижение природной газоносности под влиянием применения предварительной дегазации. Интервал времени $\mathrm{t}_{2}$ относится к процессу снижения газоносности пласта в результате приближения линии очистного забоя к скважинам и разгрузке пласта от горного давления в зоне опережающей разгрузки [16]. В период времени $\mathrm{t}_{3}$ происходит значительное снижение газоносности угля до остаточной газоносности отбиваемого в лаве угля. За время $\mathrm{t}_{4}$ происходит снижение газоносности в пределах выемочного участка в процессе транспортировки отбитого угля. Время $\mathrm{t}_{5}$ характеризует дальнейшее незначительное снижение газоносности угля за пределами выемочного участка шахты. Основными параметрами, определяющими газовыделение из отрабатываемого пласта в забое, являются его газоносность на момент отбойки $\mathrm{X}_{\mathrm{B}}$ и остаточная газоносность отбитого угля $\mathrm{X}_{\mathrm{I}}^{\mathrm{I}}$.

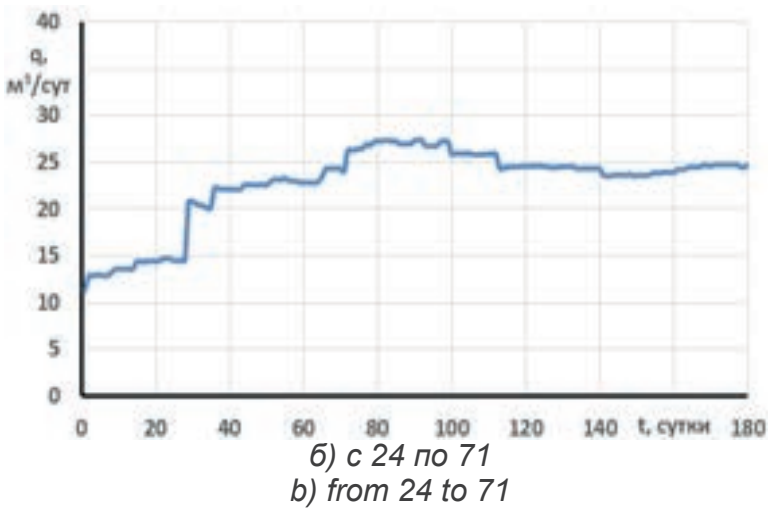

Рисунок 3 - Усредненный суточный дебит метана из дегазационных скважин Figure 3 - Averaged daily methane output from degassing boreholes 


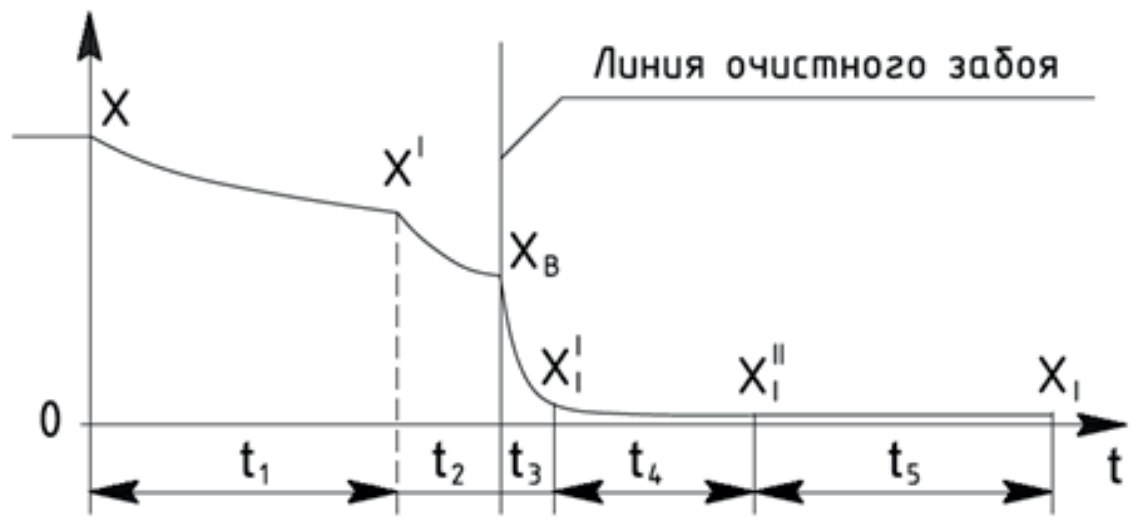

Рисунок 4 - Модель изменения газоносности пласта X и отбитого угля во времени $t$ [2] Figure 4 - Seam $X$ and crashed coal gas content changes model over time $t$ [2]

\section{Достигнутые результаты и выводы.}

Таким образом, можно рекомендовать для повышения эффективности дегазации вынимаемого пласта следующее:

1. Бурение скважин диаметром не менее $93 \mathrm{Mm}$

2. Бурение дегазационных скважин с конвейерного штрека в два ряда. Рекомендация не относится к участкам, которые располагаются в зоне влияния подготовительных выработок (монтажная камера, вентиляционный ходок). Зона распространения - по 50 м от бортов подготовительной выработки.
3. Акцентировать внимание на герметичности и работоспособности дегазационной системы в период ведения добычных работ, поскольку именно при движении забоя происходят подвижки массива и интенсивный дебит метана из скважин.

4. Применение в теле выемочного столба на большем расстоянии от подготовительных выработок способов интенсификации процессов газоотдачи угольного пласта, например, поинтервального ориентированного гидроразрыва [17].

\section{СПИСОК ЛИТЕРАТУРЫ}

1. Инструкция по дегазации угольных шахт. Серия 05. Выпуск 22. - Закрытое акционерное общество «Научнотехнический центр исследований проблем промышленной безопасности», 2012. - 250 с.

2. Инструкция по применению схем проветривания выемочных участков шахт с изолированным отводом метана из выработанного пространства с помощью газоотсасывающих установок // Утверждена приказом Федеральной службы по экологическому, технологическому и атомному надзору от 1 декабря 2011 года N 680. — 126 с.

3. Шадрин А.В., Клишин В.И. Совершенствование методов автоматизированного прогноза опасности проявления динамических явлений в процессе разупрочнения кровли и профилактической гидрообработки угольных пластов // Вестник Научного центра ВостНИИ по промышленной и экологической безопасности. — 2017. — № 3. - С. $31-35$.

4. Черданцев Н. В., Шадрин А. В. Расчет траектории движения одиночной трещины, расположенной в массиве горных пород, нагруженной давлением жидкости // Вестник Научного центра по безопасности работ в угольной промышленности. - 2017. - № 4. - C. 18 - 26.

5. Прогноз метановой опасности угольных шахт при интенсивной отработке угольных пластов / Н. М. Качурин, В. И. Клишин, А. М. Борщевич, А. Н. Качурин. Тула - Кемерово. - ТулГУ, 2013. — 220 с.

6. Portola, Vyacheslav Alekseevich. Indirect Negative Influence of Coal Mine Motor Vehicles on the Environment [Electronic resource] / V. A. Portola, E. S. Torosyan, A. S. Kuznetsova // Applied Mechanics and Materials : Scientific Journal. — 2015. — Vol. 770 : Urgent Problems of Up-to-Date Mechanical Engineering. — [P. 690-694]

7. Shadrin, Y. Diyuk. Geophysical criterion of pre-outburst coal outsqueezing from the face space into the working // International Journal of Mining Science and Technology. https://doi.org/10.1016/j.IJMST.2018.11.001

8. Полевщиков, Г.Я. Газокинетические особенности распада углеметана на конвейерном штреке выемочного участка / Г.Я. Полевщиков, М.В. Шинкевич, М.С. Плаксин // Горный информационно -аналитический бюллетень. - 2011, № 8. - С. $21-28$.

9. Kormin A.N. Seismological survey of the coal fields based on the applying of the low-power sources of oscillation / Tailakov O.V., Sokolov S.V., Makeev M.P., Kormin A.N. // E3S Web of Conferences Electronic edition, 2018, №01029, pp. 1-5 (DOI: 10.1051/e3sconf/20184101029).

10. Kormin A.N. Determination of geological conditions of gassy coal seams on the basis of seismic acoustic profiling in underground mine workings / Zastrelov D.N., Kormin A.N., Saltymakov E.A., Sokolov S.V., Taylakov O.V. // International Scientific Conference «Knowledge-based technologies in development and utilization of mineral resources», 5-8 June 2018, Novokuznetsk, Russian Federation, Volume 206, № 012046, pp. 1-6 (DOI:10.1088/1755-1315/206/1/012046).

11. Water distribution characteristic and effect on methane adsorption capacity in shale clay / Li J., Li X., Wu K., Shi J., Yang L., Feng D., Zhang T., Yu P., Wang X., Li Y. // International Journal of Coal Geology. 2016. T. 159. C. $135-154$.

12. Methane contents and coal-rank variability in the upper silesian coal basin, Poland / Kedzior S. // International Journal of Coal Geology. 2015. T. 139. № 1. C. 152-164. 
13. Numerical modelling of microseismicity associated with longwall coal mining / Cao W., Shi J.-Q., Si G., Durucan S., Korre A. // International Journal of Coal Geology. 2018. T. 193. C. 30- 45

14. Управление газовыделением в угольных шахтах при ведении очистных работ / И.В. Сергеев, В.С. Забурдяев, А.Т. Айруни и др. - М.: Недра, 1992. - 256 с.

15. .Малышев, Ю.Н. Фундаментально-прикладные методы решения проблемы угольных пластов / Ю.Н. Малышев, К.Н. Трубецкой, А.Т Айруни - М.:ИАГН, 2000. - 516 с.

16. Газовыделение из отрабатываемого пласта с учётом геомеханических процессов во вмещающем массиве / Шинкевич М.В. // Горный информационно-аналитический бюллетень (научно-технический журнал). 2013. № S6. C. 278-285.

17. Плаксин, М.С. Гидроразрыв угольного пласта в шахтных условиях как панацея решения газовых проблем шахт (основы разработки и внедрения) / М.С. Плаксин, Р.И. Родин, А.А. Рябцев, В.И. Альков, Е.В. Леонтьев, Е.С. Непеина // Уголь. - 2015. - № 2. - С. 48-50.

\section{REFERENCES}

1. Instruktsia po degazatsii ugolnykh shakht. Seria 05. Vypusk 22 [Coal mine degassing instruction. Series 05 . Issue 22]. (2012). Zakrytoie aktsionernoie obshchestvo «Nauchno-tekhnicheski tsentr issledovanii problem promyshlennoi bezopasnosti» [in Russian].

2. Instruktsia po primeneniu skhem provetrivania vyemochnykh uchastkov shakht s izolirovannym otvodom metana iz vyrabotannogo prostranstva s pomoshchiu gazootsasyvaiushchikh ustanovok // Utverzhdena prikazom Federal'noy sluzhby po ekologicheskomu, tekhnologicheskomu i atomnomu nadzoru ot 1 dekabria 2011 goda N 680. [Instructions for the use of ventilation schemes for extration sections of mines with isolated methane removal from the extracted space using gas suction units // Approved by order of the Federal Service for Ecological, Technological and Nuclear Supervision of December 1, 2011 N 680.[in Russian].

3. Shadrin, A.V. \& Klishin, V.I. (2017). Sovershenstvovanie metodov avtomatizirovannogo prognoza opasnosti proiavlenia dinamicheskikh iavleni v protsesse razuprochnenia krovli i profilakticheskoi gidroobrabotki ugolnykh plastov [Improving the methods for automated prediction of the dynamic phenomena danger in the process of softening the roof and preventive hydroprocessing of coal seams]. Vestnik nauchnogo tsentra VostNII po bezopasnosti rabot $v$ ugolnoi promyshlennosti - Herald of Safety in Mining Industry Scientific Center VostNII, 3, 31-35 [in Russian]

4. Cherdantsev, N.V., \& Shadrin, A.V. (2017). Raschet traiektorii dvizhenia odinochnoi treshchiny, raspolozhennoi v massive gornykh porod, nagruzhennoi davleniem zhidkosti [A single crack located in a rock mass, loaded with fluid pressure trajectory calculation]. Vestnik nauchnogo tsentra po bezopasnosti rabot v ugolnoi promyshlennosti-Herald of Safety in Mining Industry Scientific Center, 4, 18-26 [in Russian].

5. Kachurin, N.M., Klishin, V.I., Borshchevich, A.M., \& Kachurin, A.N. (2013). Prognoz metanovoy opasnosti ugolnykh shakht pri intensivnoi otrabotke ugolnykh plastov [Coal mine methane hazard forecast during intensive coal seam mining]. Tula - Kemerovo: TulGU [in Russian].

6. Portola, Vyacheslav Alekseevich. Indirect Negative Influence of Coal Mine Motor Vehicles on the Environment [Electronic resource] / V. A. Portola, E. S. Torosyan, A. S. Kuznetsova // Applied Mechanics and Materials : Scientific Journal. — 2015. - Vol. 770 : Urgent Problems of Up-to-Date Mechanical Engineering, p. 690-694 [in English].

7. Shadrin, Y. Diyuk. Geophysical criterion of pre-outburst coal outsqueezing from the face space into the working // International Journal of Mining Science and Technology. https://doi.org/10.1016/j.IJMST.2018.11.001 [inEnglish].

8. Polevshchikov, G.Ya., Shinkevich, M.V., \& Plaksin, M.S. (2011). Gazokineticheskie osobennosti raspada uglemetana na konveiernom shtreke vyemochnogo uchastka [Gas-kinetic features of coal-methane decomposition at the excavation section conveyor gallery]. Gorny informatsionno-analiticheskii biulleten - Mining Informational Analytical Bulletin, 8, 21-28 [in Russian].

9. Kormin A.N. Seismological survey of the coal fields based on the applying of the low-power sources of oscillation / Tailakov O.V., Sokolov S.V., Makeev M.P., Kormin A.N. // E3S Web of Conferences Electronic edition, 2018, №01029, pp. 1-5 (DOI: 10.1051/e3sconf/20184101029).[in English].

10. Kormin A.N. Determination of geological conditions of gassy coal seams on the basis of seismic acoustic profiling in underground mine workings / Zastrelov D.N., Kormin A.N., Saltymakov E.A., Sokolov S.V., Taylakov O.V. // International Scientific Conference «Knowledge-based technologies in development and utilization of mineral resources», 5-8 June 2018, Novokuznetsk, Russian Federation, Volume 206, № 012046, pp. 1-6 [in English].

11. Water distribution characteristic and effect on methane adsorption capacity in shale clay / Li J., Li X., Wu K., Shi J., Yang L., Feng D., Zhang T., Yu P., Wang X., Li Y. // International Journal of Coal Geology. 2016. T. 159. C. $135-154$. [in English].

12. Methane contents and coal-rank variability in the upper silesian coal basin, Poland / Kedzior S. // International Journal of Coal Geology. 2015. T. 139. № 1. C. 152-164. [in English].

13. Numerical modelling of microseismicity associated with longwall coal mining / Cao W., Shi J.-Q., Si G., Durucan S., Korre A. // International Journal of Coal Geology. 2018. T. 193. C. 30- 45 [in English].

14. Sergeev, I.V., Zaburdiaev, V.S., \& Airuni, A.T. (1992). Upravlenie gazovydeleniem v ugolnykh shakhtakh pri vedenii ochistnykh rabot [Gas emission control in coal mines during extraction works]. Moscow: Nedra [in Russian].

15. Malyshev, Yu.N., Trubetskoy, K.N., \& Airuni, A.T. (2000). Fundamentalno-prikladnyie metody reshenia problemy ugolnykh plastov [Fundamental - applied methods for solving coal seam problems]. Moscow: IAGN [in Russian].

16. Shinkevich, M.V. (2013). Gazovydelenie iz otrabatyvayemogo plasta s uchotom geomekhanicheskikh protsessov vo vmeshchaiushchem massive [Gas emission from the mined seam, taking into account geomechanical processes in the enclosing massif]. Gorny informatsionno-analiticheskii biulleten - Mining Informational Analytical Bulletin, S6, 278285 [in Russian].

17. Plaksin, M.S., Rodin, R.I., Riabtsev, A.A., Alkov, V.I., Leontiev, Ye.V., \& Nepeina, Ye.S. (2015). Gidrorazryv ugolnogo plasta $v$ shakhtnykh usloviakh kak panatseia reshenia gazovykh problem shakht (osnovy razrabotki i vnedrenia) [Coal seam hydraulic fracturing in mine conditions as a panacea for solving gas problems of mines (the basics of development and implementation)]. Ugol - Coal, 2, 48-50 [in Russian]. 


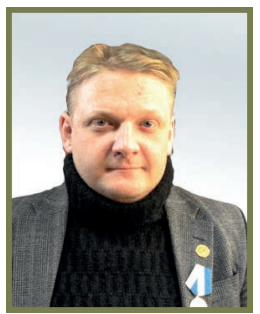

П. Б. Герике // P. В. Gericke am_besten@mail.ru

канд. техн. наук, доцент Институт угля Федерального Исследовательского Центра угля и углехимии СО РАН, 650065, г. Кемерово, пр. Ленинградский, 10 candidate of technical sciences, associate professor Institute of Coal of the Federal Research Center of Coal and Coal Chemistry of SB RAS,

10 Leningradsky Prospect, Kemerovo,

650065, Russian Federation.

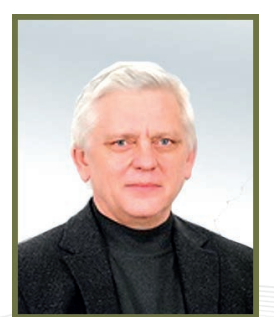

А.Г. Никитин // A.G. Nikitin nikitin1601@yandex.ru

доктор технических наук, профессор ФГБОУ ВПО СибГИУ

654041, Новокузнецк, пр. Бардина, 25 Doctor of Technical Sciences, Professor Siberian State Industrial University, Novokuznetsk, Kemerovo Region, Russia, Prospect Bardina, 25

удк 681.518 .5

\section{ДИАГНОСТИКА ПЛАНЕТАРНЫХ РЕДУКТОРОВ ПО ПАРАМЕТРАМ ВИБРАЦИИ DIAGNOSTICS OF PLANETARY GEARS BY VIBRATION PARAMETERS}

Единого диагностического критерия оценки состояния планетарных редукторов по параметрам вибрации на сегодняшний день в мире не существует. В настоящей статье предпринята попытка обобщить результаты исследований параметров вибрации, генерируемой при работе планетарных редукторов, широко используемых в горной технике, и применить полученные результаты для решения актуальной задачи по созданию единого диагностического критерия, пригодного для выполнения оценки фрактического состояния и осуществления прогнозирования процессов деградации технического состояния редукторов планетарного типа с учетом особенностей их конструкции и специфики методологии сбора диагностической инфрормации. Цель работы: на примере редукторов планетарного типа, используемых в конструкции механизмов подъема и поворота электрических карьерных экскаваторов, осуществить классификацию диагностических признаков развития дефректов диагностируемого оборудования, пригодную для дальнейшего использования при разработке методологии создания алгоритмов единых диагностических критериев оценки фрактического состояния горного оборудования по параметрам вибрации. В рамках исследования использовался комплексный подход к анализу параметров вибрации, включая спектральный анализ в расширенном частотном и динамическом диапазоне, а также анализ огибающей. Показано, что данное сочетание методов виброанализа является наиболее эфффективным для решения задачи по выявлению базовых диагностических признаков диагностируемого оборудования и осуществлению их дальнейшей формализации. Полученные в рамках настоящего исследования научные результаты доказывают принципиальную эфрфективность предложенного методологического подхода для решения задачи по созданию алгоритмов разработки единых диагностических критериев оценки и прогнозирования процесса изменения технического состояния планетарных редукторов.

There is no single diagnostic criterion for assessing the state of planetary gears by vibration parameters in the world today. This article presents the results of research of the parameters of vibration generated during operation of planetary gears widely used in mining equipment. The results are used to create a single diagnostic criterion suitable for assessing the actual state and forecasting the degradation of the technical condition of planetary gears. The main aim of the research: using the planetary gears as an example, used in the construction of lifting and turning mechanisms for electric mining shovels, we can classify the diagnostic signs of the development of defects in the diagnosed equipment, suitable for further use in developing a methodology for creating algorithms for unified diagnostic criteria for assessing the actual state of mining equipment by vibration parameters. In this work, we used an integrated approach to the analysis of vibration parameters, including spectral analysis in the extended frequency and dynamic range and envelope analysis. It is shown that this combination of vibration analysis methods is most effective for solving the problem of identifying the basic diagnostic features of the diagnosed equipment and implementing their further formalization. The scientific results obtained in the framework of this research prove the principal effectiveness of the proposed methodological approach for solving the problem of creating algorithms for developing common diagnostic criteria for assessing and predicting the degradation of the technical condition of planetary gearboxes.

КлючевЫе слова: ВИБРОДИАГНОСТИКА, ПЛАНЕТАРНЫЕ РЕДУКТОРА, ЭНЕРГО-МЕХАНИЧЕСКОЕ 
ОБОРУДОВАНИЕ, КАРЬЕРНЫЕ ЭКСКАВАТОРЫ, МЕХАНИЧЕСКИЕ ДЕФЕКТЫ.

Key words: VIBRATION ANALYSIS, PLANETARY GEARS, ENERGOMECHANICAL EQUIPMENT, MINING SHOVELS, MECHANICAL DEFECTS.

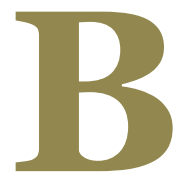

ведение.

Благодаря своей эфффективности и компактности редуктора планетарного типа получили широкое распространение в горном машиностроении. В электрических карьерных экскаваторах они используются в конструкции механизмов подъема и поворота (ЭКГ-10, ЭКГ-12,5 (6,3у), ЭКГ-15 и т.д.). Анализ параметров вибрации, генерируемой при работе планетарных редукторов, усложняется наличием в спектре большого числа составляющих «зубцовой» природы и ограниченным доступом к точкам проведения измерений, что сильно затрудняет интерпретацию получаемых данных [1].

Результаты анализа позволяют распознавать все основные дефекты планетарных редукторов: неуравновешенность вращающихся деталей, нарушение соосности валов, погрешности изготовления эпицикла, солнца и сателлитов, кинематические погрешности пересопряжения зубчатых шестерен, износ и изменение геоме-

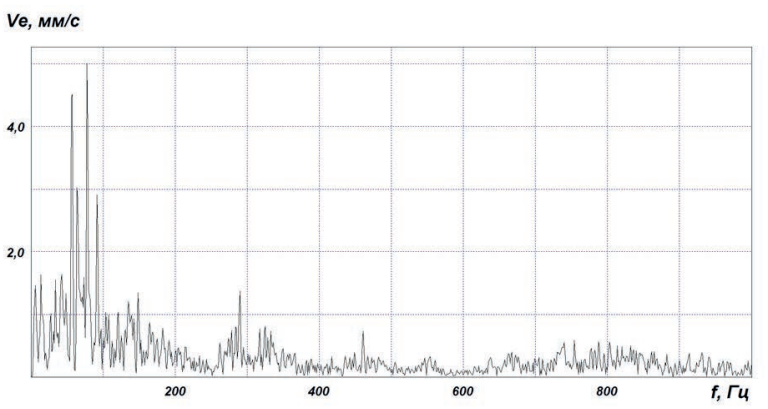

А) Неуравновешенность вращающихся деталей первой ступени редуктора механизма подъема экскаватора ЭКГ-10

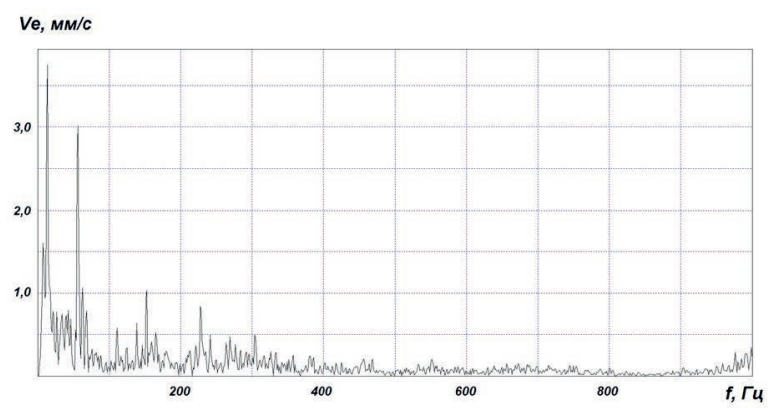

Б) Ослабление посадки подшипника входного вала редуктора и общее нарушение жесткости опорной системы редуктора механизма поворота экскаватора WK-35

Рисунок 1. Спектры, иллюстрирующие наличие наиболее распространенных повреждений редукторов

Рисунок 1. Спектры, иллюстрирующие наличие наиболее распространенных повреждений редукторов

Figure 1. Spectra illustrating the presence of the most common planetary type gear damage трии зубчатых пар, ослабления крепежа. Однако на сегодняшний день отсутствует единый диагностический критерий оценки состояния планетарных редукторов по параметрам вибрации, который с одинаковым успехом мог быть применен для оценки фактического состояния данного оборудования и использован для построения прогноза процесса деградации его технического состояния.

Результаты и их применение. Исследования в области изучения процессов фрормирования и развития вибрационной активности, осуществляемые в рамках выполнения процедуры экспертизы промышленной безопасности технических устройств, эксплуатируемых в условиях угольной промышленности Кузбасса, позволили сфрормировать представительный объем банков данных статистической информации и сформулировать критерии предельного состояния редукторов различного типа и конструкции, применяющихся в горной технике [2].

Выполнение анализа диагностических данных заметно усложняют такие фракторы, как

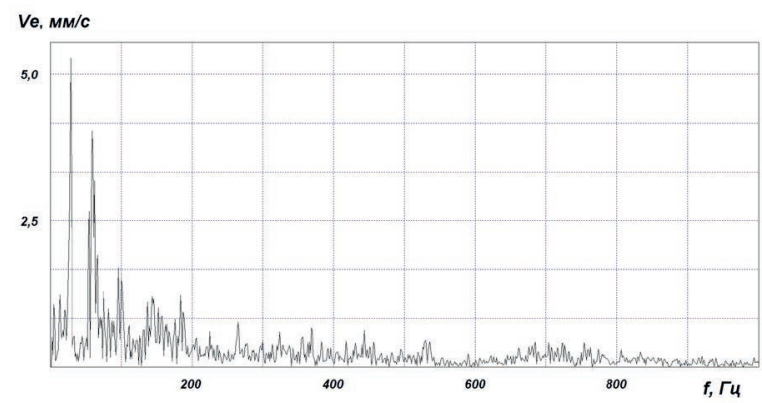

В) Расцентровка редуктора подъема экскаватора ЭКГ-10 с правым электродвигателем

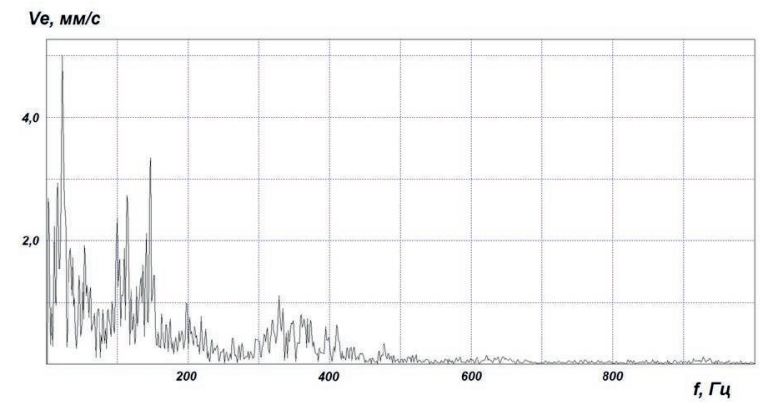

Г) Износ зубчатых зацеплений первой ступени редуктора подъема экскаватора ЭКГ-10 
низкие частоты вращения, цикличность работы оборудования, ударные нагрузки и источники случайной высокочастотной вибрации, именно поэтому возможности применения методов вибродиагностики на объектах данного типа существенно ограничены [3]. Таким образом, наиболее эффрективным способом оценки текущего состояния редукторов планетарного типа является одновременное использование нескольких различных диагностических методологий, что позволяет выявлять все основные типы повреждений данного оборудования (износ зубчатых зацеплений, расцентровка валов, неуравновешенность вращающихся деталей и т.п.). В рамках настоящей работы применялся комплексный диагностический подход к анализу регистрируемых параметров механических колебаний, включающий в себя спектральный анализ и анализ огибающей спектра.

Результаты комплексного подхода к анализу параметров вибрации, генерируемой при работе редукторов планетарного типа, позволили обобщить имеющуюся статистическую информацию и разработать предпосылки для создания единого диагностического критерия оценки состояния данного оборудования.

На рисунке 1 представлены реальные спектры по параметру виброскорости, иллюстрирующие наличие большого числа наиболее распространенных диагностических признаков, свидетельствующих о развитии процессов деградации технического состояния узлов и механизмов горной техники, в конструкции которой используются планетарные редуктора.

Так, на рисунке 1 А приведен пример наличия неуравновешенности вращающихся деталей планетарного редуктора механизма подъема экскаватора ЭКГ-10. Уровень вклада значащих составляющих спектра незначителен и вызван заводской погрешностью изготовления зубчатых пар, замененных при проведении капитального ремонта редуктора. Обычно в качестве диагностических признаков неуравновешенности используются оборотные частоты валов или шестерен, но в случае диагностирования планетарных редукторов необходимо рассматривать широкий ряд информативных составляющих, включая боковые полосы, которыми при развитии дефектов «обрастают» частоты вращения солнца, водила и сателлитов.

Наиболее распространенным дефектом планетарных редукторов, используемых в конструкции горной техники, является нарушение жесткости системы, признаки которого встречаются практически повсеместно. Рисунок 1Б ил- люстрирует присутствие в спектре виброакустического сигнала набора базовых диагностических признаков ослабления посадки подшипника входного вала редуктора и общего нарушения жесткости опорной системы редуктора механизма поворота экскаватора WK-35, в частности наличие гармонического ряда нарушения жесткости и рост шумовых компонент.

Расцентровка валов агрегатов также является распространенной проблемой механизмов подъема и поворота электрических карьерных экскаваторов, оснащенных редукторами планетарного типа. Признаки расцентровки электрических двигателей с редукторами встречаются примерно на $30 \%$ объектов из обследованной выборки (см. пример на рисунке 1В). В этом случае в спектре, как правило, преобладает вторая - третья компонента частоты вращения электродвигателя, причем амплитуды значащих гармоник возрастают в тех плоскостях пространственного положения агрегата, где несоосность установки валов проявляется больше (достаточно широкое распространение на агрегатах горной техники получила т.н. «горизонтальная» несоосность по причине низкой квалификации обслуживающего и ремонтного персонала). Гораздо реже удается выявить признаки нарушения соосности валов первой и второй ступени планетарных редукторов, что может объясняться быстрым наступлением аварийного выхода агрегатов из строя. Разрушение и/или заклинивание шестерен в случае расцентровки валов и общего нарушения геометрии зубчатых зацеплений в планетарных редукторах развивается очень быстро, что часто не позволяет вовремя выявить и оценить соответствующие этому процессу диагностические признаки $[1,2,4]$.

В данном случае анализ данных по параметру виброскорости позволил выявить некритичное нарушение соосности валов первой и второй ступени, а также некритичный абразивный износ сателлитов первой ступени редуктора механизма подъема экскаватора ЭКГ-10 (см. рисунок 1Г). Нарушение соосности или перекос валов в редукторах, используемых в конструкции карьерных экскаваторов, является довольно распространенным дефектом, обычно возникающим вследствие проведения низкоквалифицированных ремонтов. Результатом нередко становится рост вибронагруженности агрегатов, вызванный процессами интенсивного развития дефектов зубчатых зацеплений.

Для того чтобы своевременно выявлять развитие разрушительных процессов, сопровождающих появление дефектов зубчатых пере- 
дач в составе планетарных редукторов и использовать максимальное число эффективных признаков при разработке единого диагностического критерия, необходимо учитывать глубину модуляции «зубчатых» частот, общий уровень шума и флуктуации гармоник, а также применять результаты анализа огибающей спектра в области информативных частот проявления дефектов. Полученные в рамках настоящей работы результаты свидетельствуют, что именно такое сочетание методов контроля вибрации позволит эффрективно выявлять дефекты редукторов планетарного типа с минимальными затратами времени на сбор и анализ диагностической инфрормации.

Общий уровень вибрационной активности агрегата на рисунке 1Г классифицируется как допустимый, за причину абразивного износа зубчатых зацеплений можно принять нарушение жесткости системы и незначительную несоосность валов редуктора. Несмотря на это данные процессы могли в короткий срок привести к аварийной остановке и разрушению вращающихся элементов, что обусловлено особенностями конструкции планетарного редуктора $[1,5]$. Поэтому эксплуатирующему предприятию было выдано предписание об остановке экскаватора и проведении ревизии зубчатых зацеплений редуктора, которая подтвердила правильность результатов контроля, что позволило своевременно выполнить виброналадку агрегата.

Алгоритмы расчетов для детектирования составляющих зубцовой природы на объектах данного типа являются более громоздкими по сравнению с методологией расчета на редукторах переборного типа, что существенно усложняет проводимый анализ и увеличивает время, затрачиваемое на выявление дефектов. Частоты пересопряжения зубьев, частоты вращения сателлитов и водила каждой ступени редуктора постоянно изменяются в процессе работы в довольно широком диапазоне, и отследить наличие диагностических признаков дефектов зубчатых передач на редукторах планетарного типа в ручном режиме при осуществлении спектрального анализа в расширенном частотном диапазоне довольно затруднительно, учитывая большой объем диагностической информации и времени, затрачиваемого на ее анализ [6, 7].

В рамках выполнения настоящей работы использовалась выборка, состоящая из двадцати единиц электрических карьерных экскаваторов, в конструкции которых применен привод основных механизмов с использованием планетарных редукторов. Полученные результаты контроля по параметрам вибрации позволили сформулировать требования к оборудованию и методам диагностирования, а также выполнить обоснованную оценку технического состояния данного типа механических объектов на основе комплекса проведенных научных исследований.

В общем виде всем основным видам дефектов редукторов планетарного типа соответствует около пятидесяти диагностических признаков в области контроля вибрации, из-за сложности формализации только около 50\% из них может быть использовано при создании алгоритмов единых диагностических критериев оценки фактического состояния горного оборудования. Формализации в первую очередь подверглись дефекты, сопровождаемые развитием высокоэнергетических процессов (расцентровка привода, несоосность валов, неуравновешенность вращающихся деталей) из-за высокой вероятности аварийного выхода механизма из строя. Кроме того, также были формализованы (представлены в виде, удобном для создания единого критерия оценки) дефекты, которым соответствует большое количество четко классифицированных диагностических признаков (зубчатые зацепления, подшипники). Наличие большого числа типовых дефектов послужило причиной для разработки алгоритмов клиппирования, предназначенных для детектирования информативных гармонических составляющих спектра в условиях неявного максимума оборотной частоты [8, 9]. Число созданных в рамках проводимого цикла исследований алгоритмов клиппирования совпадает с потенциальным количеством дефектов, которые соответствуют обследуемому типу оборудования (по одному алгоритму для дефектов зубчатых передач, расцентровки, нарушения жесткости системы, подшипников). В результате вся исходная диагностическая информация была подвергнута фрильтрации, благодаря чему удаляются все составляющие спектра иной природы (причина возникновения которых не имеет отношения к рассматриваемому типу дефектов), а также убираются искажения, вызванные нарушением технологии производства замеров, наличием повреждений в соединительных кабелях или разъемах, а также погрешностью математической обработки получаемой информации [3, 10, 11].

Одной из основных целей, поставленных перед настоящим исследованием, является создание единого критерия оценки состояния редукторов планетарного типа по результатам анализа вибрации, использование которого на практике значительно сократило бы трудозатраты на 
проведение диагностирования и повысило точность получаемых результатов. При разработке единого диагностического критерия необходимо определить свой уникальный набор диагностических признаков, которые наиболее оптимально описывают состояние обследуемого объекта, а также осуществить выбор и нормирование предельных значений критериев оценки фактического состояния работающего оборудования $[12,13]$. Полученные в рамках выполнения настоящей работы научные результаты показали, что для диагностики зубчатых передач в составе редукторов планетарного типа наиболее эффрективной является реализация следующего комплекса диагностических признаков:

- вклад совокупности «зубчатых» составляющих в величину общего уровня среднеквадратического значения (СКЗ) виброскорости и виброускорения, а также оценка максимумов отдельных амплитуд гармоник «зубчатых» частот в стандартном и расширенном частотных диапазонах;

- степень модуляции значащих гармоник, наличие субгармоник и обертонов гармонических рядов «зубчатой» природы;

- наличие в спектре гармонических рядов перекоса сателлитов, солнечной шестерни или короны;

- рост шумовой компоненты спектра и фрлуктуация «зубчатых» гармоник, свидетельствующие о развитии вибрационных процессов, вызванных неуравновешенностью вращающихся деталей редуктора.

Существующие алгоритмы нормирования спектрального состава регистрируемых характеристик и оценки вклада отдельных гармоник «зубчатой» природы и уровней в частотных полосах являются несовершенными, что обусловлено необходимостью выполнения практически с нуля всей трудоемкой работы по нормированию механических колебаний при смене объекта диагностирования [14]. Именно поэтому результаты нормирования вибрации с использованием спектральных масок остались за рамками настоящей работы. В качестве базовой платформы для осуществления нормирования вклада составляющих «зубцовой» природы в общий уровень вибрации при разработке алгоритма создания единого диагностического критерия оценки и прогнозирования фактического состояния планетарных редукторов были использованы существующие рекомендации по оценке и нормированию вибрации энерго-механического оборудования горных машин [15]. Дополнительные сложности при расчете значащих составля- ющих привносят конструктивные особенности исполнения планетарных редукторов, используемых в конструкции горных машин (неподвижная солнечная шестерня, неподвижное водило, неподвижный эпицикл). В зависимости от изменяющихся конструктивных параметров редуктора меняются зависимости, используемые для расчета частот вращения сателлитов, таким образом, изменяются и наборы составляющих «зубчатых» частот. Как следствие, усложняются алгоритмы поиска информативных составляющих спектра, используемых для разработки единого диагностического критерия и осуществления прогнозного моделирования.

Реальная потребность в осуществлении долгосрочного прогнозирования процессов изменения технического состояния горных машин сегодня фактически отсутствует из-за системы планово-предупредительных ремонтов, действующей на угольных предприятиях Кузбасса. Использование алгоритмов адаптивного краткосрочного прогнозирования позволит осуществить эффрективное моделирование деградационных процессов технического состояния редукторов планетарного типа на основе данных контроля вибрации [3,9]. Кроме того, применение математического прогнозного моделирования в качестве структурного элемента системы обслуживания горных машин по фрактическому техническому состоянию позволит эффективно управлять планированием ремонтов, логистикой и складским хозяйством угольных разрезов.

Большинство алгоритмов прогнозного моделирования, основанных на результатах контроля вибрации, используют в своей работе принципы прогнозирования изменения процесса изменения величины общего уровня вибрации, что свидетельствует об ограниченном функционале существующего программного обеспечения в области виброанализа, что значительно затрудняет использование результатов моделирования для построения адекватного прогноза деградации технического состояния оборудования горных машин. Полученные в рамках проводимого цикла работ научные результаты доказали принципиальную эффективность реализации предложенного набора диагностических признаков для формирования единого критерия оценки состояния зубчатых передач в составе редукторов планетарного типа [2, 9, 16].

Выводы. На сегодняшний день на рынке программного обеспечения отсутствуют математические модели, основанные на моделировании величины единого диагностического критерия, пригодного для осуществления контроля и 
прогнозирования процесса изменения технического состояния редукторов планетарного типа. Существующие прогнозные модели, где используются схожие критерии, имеют крайне ограниченную область применения, что указывает на необходимость их совершенствования. Примером реализации такой модели, где моделируется процесс изменения единого диагностического критерия для выявления нарушения соосности валов агрегатов, может служить прогнозирование безаварийной работы малой генераторной группы экскаватора-драглайна [9]. Результаты реализации модели показали высокую степень точности получаемых данных в рамках выбранной группы объектов диагностирования, что подтверждает эффективность предложенной методологии анализа параметров вибрации.

Новизна предлагаемой математической модели заключается в том, что на примере планетарных редукторов предпринята попытка замены большого количества диагностических признаков, правил, критериев и методологий только лишь одним критерием, адаптивное моделирование величины которого позволит с заданной вероятностью прогнозировать процесс изменения фактического состояния объекта диагностирования. В конечном счете единые диагностические критерии, которые разрабатываются для каждой группы дефектов с учетом особенностей конструкции и условий эксплуатации горных машин, создаваемые при помощи алгоритмов скаляризации для многомерного пространства диагностических признаков, позволят полностью описать фактическое состояние любой сложной механической системы, включая изменение базовых параметров надежности с течением времени.
Заключение. Действующая сегодня на предприятиях ТЭК Кузбасса система плановопредупредительных ремонтов не позволяет оптимизировать качество проводимых ремонтов и выполнять эффективную оценку остаточного ресурса эксплуатируемой техники. Результаты проведенных исследований однозначно указывают на необходимость внедрения на промышленных предприятиях угольной отрасли системы обслуживания техники по её фрактическому техническому состоянию, в качестве базовых элементов которой могут выступить наработки, полученные в рамках выполнения настоящей работы. Например, одним из таких элементов может выступить комплекс диагностических признаков и правил, а также единые диагностические критерии для выявления дефектов различного энерго-механического оборудования горной промышленности по результатам анализа параметров механических колебаний, генерируемых при его работе [2, 9, 16]. Моделирование процессов развития дефектов технологического оборудования на основе разрабатываемых единых критериев может использоваться для осуществления прогнозирования фрактического состояния широкого типового ряда горного оборудования, что позволит угольным предприятиям выйти на качественно новый уровень технического обслуживания. Современный подход к анализу параметров вибрации, генерируемой при работе горного оборудования с использованием алгоритмов прогнозного моделирования и единых критериев оценки снизит долю непроизводительных простоев по причине аварийного выхода оборудования из строя, что повысит безопасность выполнения горных работ на угольных предприятиях Кузбасса.

\section{СПИСОК ЛИТЕРАТУРЫ}

1. Неразрушающий контроль. Справочник в 7 томах под редакцией чл.-корр. РАН В.В. Клюева, т.7 - Москва, 2005. $-828 \mathrm{c}$.

2. Герике П.Б. Неразрушающий контроль дробильно-сортировочного оборудования на обогатительных фрабриках Кузбасса /П. Б. Герике// Вестник Научного центра по безопасности работ в угольной промышленности, №2. Кемерово. - 2019. С. 62-69

3. Сушко А. Е. Разработка специального математического и программного обеспечения для автоматизированной диагностики сложных систем. Дисс. ... канд. техн. наук. - М. - МИФИ. - 2007. - 170 с.

4. Puchalski A., Komorska I. Stable distributions and fractal diagnostic models of vibration signals of rotating systems. Applied Condition Monitoring. 2018, Vol. 9. Pp 91-101. https://doi.org/10.1007/978-3-319-61927-9_9

5. V. Pozhidaeva. Determining the roughness of contact surfaces of the rolling bearings by the method of shock pulses. World Tribology Congress III, September 12-16, 2005, Washington, D.C., USA

6. F. Balducchi, M. Arghir, S. Gaudillere. Experimental analysis of the unbalance response of rigid rotors supported on aerodynamic foil bearings. Proceedings of ASME Turbo Expo 2014: Turbine Technical Conference and Exposition GT2014. June 16 - 20, 2014, Düsseldorf, Germany.

7. Puchalski A. «A technique for the vibration signal analysis in vehicle diagnostics», Mechanical Systems and Signal Processing \#56-57(2015). 173-180

8. Trebuna F., Šimcak F., Bocko J., Hunady R., Pastor M. «Complex approach to the vibrodiagnostic analysis of excessive vibration of the exhaust fan», Engineering Failure Analysis \#37 (2014). 86-95

9. Герике П.Б. Классификация дефектов генераторных групп экскаваторов-драглайнов применительно к созданию алгоритмов клиппирования /П.Б. Герике// Горное оборудование и электромеханика, № 2. - Кемерово. - 
2019. - C. 22-29

10. Schreiber, R. Induction motor vibration diagnostics with the use of stator current analysis. Proceedings of the 2016 17th International Carpathian Control Conference, ICCC 2016. Pp. 668-672. https://doi.org/10.1109/ CarpathianCC.2016.7501179

11. Shardakov I., Shestakov A., Tsvetkov R., Yepin V. Crack diagnostics in a large-scale reinforced concrete structure based on the analysis of vibration processes. AIP Conference Proceedings 2053, 040090 (2018). https://doi. org/10.1063/1.5084528

12. Ширман А.Р. Практическая вибродиагностика и мониторинг состояния механического оборудования / Ширман А.Р., Соловьев А.Б. / Москва, 1996. - 276 с.

13. Барков А.В. Вибрационная диагностика машин и оборудования. Анализ вибрации. Учебное пособие. / Барков А.В., Баркова Н.А. / Издательство СПбГМТУ. Санкт Петербург, 2004. - 156 с.

14. Wang, T., Han, Q., Chu, F., Feng, Z. Vibration based condition monitoring and fault diagnosis of wind turbine planetary gearbox : A review. Mechanical Systems and Signal Processing. 2019. V.126,. Pp. 662-685. https://doi.org/10.1016/j. ymssp.2019.02.051

15. РД-15-14-2008. Методические рекомендации о порядке проведения экспертизы промышленной безопасности карьерных одноковшовых экскаваторов

16. Диагностика энерго-механического оборудования карьерных экскаваторов по результатам анализа вибрации /Клишин В.И., Герике П.Б.// Фундаментальные и прикладные вопросы горных наук, т.5, №2. - Новосибирск. 2018. С. $221-228$

\section{REFERENCES}

1. Nerazrushayushchiy kontrol': spravochnik. V 7-kh tomakh [Non-destructive testing: Handbook. In 7 Vol. V.7] / Pod. red. V.V. Klyueva. Moscow: Mashinostroenie Publishers, 2005. 828 p. (rus)

2. Gericke P.B. Vestnik nauchnogo centra po bezopasnosti rabot v ugol'noj promyshlennosti. 2019. \#2. Pp. 62-69. (rus)

3. Sushko A. E. Razrabotka spetsial'nogo matematicheskogo i programmnogo obespecheniya dlya avtomatizirovannoy diagnostiki slozhnykh system [Development special mathematical and software for automated diagnosis of complex systems]: PhD thesis excerpt. Moscow. 2007. (rus)

4. Puchalski A., Komorska I. Stable distributions and fractal diagnostic models of vibration signals of rotating systems. Applied Condition Monitoring. 2018, Vol. 9. Pp 91-101. https://doi.org/10.1007/978-3-319-61927-9_9 (eng)

5. V. Pozhidaeva. Determining the roughness of contact surfaces of the rolling bearings by the method of shock pulses. World Tribology Congress III, September 12-16, 2005, Washington, D.C., USA

6. Balducchi F., Arghir M., Gaudillere S. Experimental analysis of the unbalance response of rigid rotors supported on aerodynamic foil bearings. Proceedings of ASME Turbo Expo 2014: Turbine Technical Conference and Exposition GT2014. June 16 - 20, 2014, Düsseldorf, Germany. URL: http://proceedings.asmedigitalcollection.asme.org/ (eng)

7. Puchalski A. «A technique for the vibration signal analysis in vehicle diagnostics», Mechanical Systems and Signal Processing \#56-57(2015). Pp. 173-180 (eng)

8. Trebuna F., Šimcak F., Bocko J., Hunady R., Pastor M. «Complex approach to the vibrodiagnostic analysis of excessive vibration of the exhaust fan», Engineering Failure Analysis \#37 (2014). Pp. 86-95 (eng)

9. Gericke P.B. Gornoe oborudovanie i jelektromehanika. 2019. \#2. Pp. 22-29. (rus)

10. Schreiber, R. Induction motor vibration diagnostics with the use of stator current analysis. Proceedings of the 2016 17th International Carpathian Control Conference, ICCC 2016. Pp. 668-672. https://doi.org/10.1109/ CarpathianCC.2016.7501179 (eng)

11. Shardakov I., Shestakov A., Tsvetkov R., Yepin V. Crack diagnostics in a large-scale reinforced concrete structure based on the analysis of vibration processes. AIP Conference Proceedings 2053, 040090 (2018). https://doi. org/10.1063/1.5084528 (eng)

12. ShirmanA.R., Solov'evA.B. Prakticheskaya vibrodiagnostika i monitoring sostoyaniya mekhanicheskogo oborudovaniya [The practical vibration analysis and monitoring of mechanical equipment] Moscow: Spectrum engineering Publishers, 1996. 276 p. (rus)

13. Barkov A.V., Barkova N.A. Vibratsionnaya diagnostika mashin i oborudovaniya. Analiz vibratsii [Vibration diagnostics of machines and equipment. Vibration analysis: Handbook]. St. Petersburg, 2004. 156 p. (rus)

14. Wang, T., Han, Q., Chu, F., Feng, Z. Vibration based condition monitoring and fault diagnosis of wind turbine planetary gearbox: A review. Mechanical Systems and Signal Processing. 2019. V.126,. Pp. 662-685. https://doi.org/10.1016/j. ymssp.2019.02.051 (eng)

15. RD-15-14-2008. Metodicheskie rekomendacii o porjadke provedenija jekspertizy promyshlennoj bezopasnosti kar'ernyh odnokovshovyh jekskavatorov (rus)

16. Klishin V.I., Gerike P.B. Fundamental'nye i prikladnye voprosy gornyh nauk, Vol.5, \#2. - Novosibirsk. - 2018. Pp. 221228 (rus) 


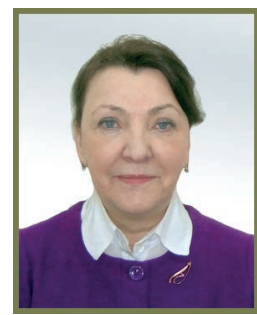

A.В.Дягилева //A.V.Diagileva

канд.техн.наук, доцент, доцент ФГБОУ ВО «Кузбасский государственный технический университет имени Т.Ф.Горбачева» (КузГТУ), Россия, 650026, г.Кемерово, ул.Весенняя, 28 Candidate of technical sciences, associate professor of FGBOU VO "Kuzbass State Technical University named after T.F.Gorbachev (KuzSTU), 28, Vesenniaia St., Kemerovo, 650026 , Russia"

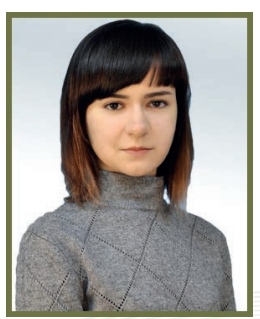

А.В.Каплун//A.V.Kaplun nastiakaplun@yandex.ru

студент ФГБОУ ВО «Кузбасский государственный технический университет имени Т.Ф.Горбачева» (КузГТУ), Россия, 650026, г.Кемерово, ул.Весенняя, 28c

Student of FGBOU VO "Kuzbass State Technical University named after T.F.Gorbachev (KuzSTU), 28, Vesenniaia St., Kemerovo, 650026 Russia"

УДК 519.254

«СРАВНИТЕЛЫНЫЙ АНАЛИЗ ФОРМУЛ ПО НАХОЖКДЕНИЮ ДЛИНЫ ШАГА ИНТЕРВАЛЬНОГО ВАРИАЦИОННОГО РЯДА ПРИ СТАТИСТИЧЕСКОЙ ОБРАБОТКЕ РЕЗУЛЬТАТОВ ШАХТНЫХ ИССЛЕДОВАНИЙ ТЕХНОЛОГИЧЕСКИХ РЕЖИМОВ ВЕДЕНИЯ ГОРНЫХ РАБОТ» «COMPARATIVE ANALYSIS OF FORMULAS FOR FINDING THE LENGTH OF INTERVAL VARIATION SERIES' STEP IN THE STATISTICAL DATA PROCESSING OF THE RESULTS OF MINE RESEARCHES OF TECHNOLOGICAL OPERATION OF MINING MODES»

В настоящее время математическая статистика является неотъемлемой частью анализа различных сорер производственной деятельности. С её помощью формируются эмпирические гипотезы, которые в дальнейшем позволяют корректировать всевозможные процессы на предприятиях. Последствия ошибочного опровержения или подтверждения статистических гипотез могут различаться по уровню значимости, а в условиях повышенного риска могут нанести непоправимый ущерб здоровью и жизни сотрудников, а также привести к существенным нарушениям производственных процессов. Поэтому для соблюдения норм охраны труда на опасных производственных объектах необходимо тщательно анализировать различные наборы данных. По причине повышенной ответственности за результат анализа гипотез важен правильный выбор статистических критериев. Одним из вариантов определения точности критерия является работа с одними и теми же данными с использованием сравниваемых критериев. В данной статье содержится подобный анализ трех формул по нахождению длины шага интервального вариационного ряда, статистическое исследование экспериментальных данных, а также описаны основные критерии анализа, на основе результатов которых фрормировалась оценка точности той или иной фрормулы длины шага.

Currently, mathematical statistics is an integral part of the analysis of various spheres of production activity. With its help, empirical hypotheses are formed, which in the future allow you to adjust all kinds of processes in enterprises. The consequences of erroneous refutation or confirmation of statistical hypotheses may vary in level of significance, and in conditions of increased risk can cause irreparable damage to the health and life of employees, as well as lead to significant disruption of production processes. For this reason, in order to comply with occupational safety standards at hazardous production facilities, it is necessary to carefully analyze different data sets. Due to the elevated responsibility for the result of hypothesis analysis, the correct choice of statistical criteria is important. One way to determine the accuracy of the criterion is to work with the same data using the compared criteria. The article contains a comparative analysis of three different formulas of finding the length of interval variation series' step, a statistical research of experimental data, and describes the main criteria for statistical analysis, on the basis of the results of which an evaluation of the accuracy of the formula of step length was formed.

Ключевые слова: ДЛИНА ИНТЕРВАЛА, АНАЛИЗ СЛУЧАЙНОЙ ВЕЛИЧИНЫ, ЗАКОН РАСПРЕДЕЛЕНИЯ, ГИСТОГРАММА, СТЁРДЖЕСС, ФРИДМАН, СКОТТ, ШАХТНЫЕ ИССЛЕДОВАНИЯ, ГОРНЫЕ РАБОТЫ 
Key words: THE LENGTH OF THE INTERVAL, ANALYSIS OF RANDOM VALUE, DISTRIBUTION LAW, HISTOGRAM, STURGES, FREEDMAN, SCOTT, MINE RESEARCHES, MINING.

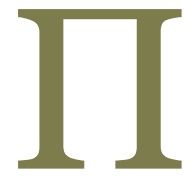

\section{остановка задачи}

Математическая статистика в горной промышленности служит важнейшим инструментом анализа и прогнозирования экспериментальных данных временного ряда в таких условиях риска, где особенно важны точность выбранных показателей и критериев статистического анализа. Например, существует множество способов для нахождения длины интервала вариационного ряда. Наиболее распространённым в настоящее время является эмпирическое правило Стёрджесса (1926 г.), определяющее количество интервалов, на которое необходимо разбить наблюдаемый диапазон случайной величины:

$$
n=1+\left[\log _{2} N\right]=1+[3,322 \lg N]
$$

где $N$ - количество измерений случайной величины. Соответственно, величина равных интервалов определяется по следующей фрормуле:

$$
i=(X \max -X \min ) / n,
$$

где $i$ - величин интервала, Хmax и Xmin - максимальное и минимальное значения в выборке, а $n$ - число интервалов. Подобный метод не дает объективно точного результата и позволяет строить относительно достоверные гистограммы только при $n<200$. В связи с этим следует обратиться к альтернативным способам нахождения длины интервала вариационного ряда.

$$
\begin{aligned}
& \text { Рассмотрим пару из них: } \\
& \text { 1. } \quad \text { Формула Скотта (1979 г.) } \\
& h=3,5 s n^{-1 / 3}
\end{aligned}
$$

где $h$ - длина интервала, $s$ - стандартное отклонение значений ряда измерений, $n-$ число интервалов;

$$
S=\sqrt{\frac{\sum_{i=1}^{n}\left(x_{i}-x_{\mathrm{cp}}\right)^{2}}{n-1}},
$$

где $x_{c p}$ - среднее арифметическое выборки.

2. ормула Фридмана Диакониса (1981 г.)

$$
h=2(I Q) n^{-1 / 3}
$$

где $h$ - длина интервала, $n$ - число интервалов, $(I Q)$ - разница между верхним и нижним квартилем - значением, делящим выборку на 4 приблизительно равные части.

Данные формулы достаточно просты в использовании и обоснованы статистической теорией, что дает им преимущество в сравнении с эмпирически выведенной формулой Стёрджесca.

Ниже проведем исследование на основе этих трех методов и выясним, какой является наиболее предпочтительным.

\section{Анализ случайной величины X:}

Имеются 76 различных профессий горной отрасли, в каждой из которых на производствах задействовано определённое количество работников (не больше 100 сотрудников в одной специальности). Анализируется набор данных, содержащий количественные составы каждой профессии (случайная величина $X$ ), с целью проведения статистического анализа одномерных данных.

Замечание: поскольку в статье приводится исследование точности формул по нахождению интервала вариационного ряда с одними и теми же данными, но разными начальными формулами, кратко опишем порядок вычислений в общем виде, а затем приведем сравнительную таблицу с полученными величинами.

Предположим, что изучается некоторая случайная величина $X$, закон распределения которой неизвестен. Требуется приближенно определить этот закон из опыта и проверить гипотезу о том, что случайная величина $X$ подчинена этому закону.

Имеем следующие данные: 45, 33, 50, 39, $45,50,45,65,45,33,56,45,56,62,50,60,62,39$, $56,50,50,45,62,56,70,88,45,27,76,62,68,56$, 62, 56, 65 56, 74, 72, 70, 62, 76, 45, 56, 62, 65, 92, $72,45,84,62,78,72,72,84,56,33,52,39,56,76$, $56,62,62,65,50,62,70,68,68,62,72,72,73$, $27,56,62$.

Составим интервальный вариационный ряд, определив величину интервала (шага) по одной из указанных формул. Если $h$ окажется дробным, то за величину интервала принимается ближайшее целое значение.

Запишем статистическое распределение признака (интервальный вариационный ряд) и построим гистограмму и полигон распределения. Гистограмма - график, состоящий из прямоугольников, основаниями которых являются интервалы значений признака $(O x)$, а высота равна частоте соответствующего интервала $(O y)$.

Для того чтобы вывести закон распределения, используют следующий алгоритм: выдвигается гипотеза о предполагаемом законе распределения (нулевая гипотеза) $-H_{0}$, на основе анализа гистограммы и числовых характеристик (выборочная средняя $X_{b}$, среднее квадратичное отклонение $\left.\sigma_{b}(x)\right)$. Затем проверяют адекватность модели по критерию Пирсона. По выборке вычисляют наблюдаемое значение критерия 
Пирсона:

$$
x_{\text {набл }}^{2}=\sum_{i=1}^{r} \frac{\left(n_{i}-n_{i}^{T}\right)^{2}}{n_{i}^{T}}
$$

где $n_{i}^{T}$ - теоретические частоты, полученные в результате расчетов по предполагаемому закону распределения, $r$ - число интервалов вариационного ряда. Определяют число степеней свободы $k=r-\delta-1$, где $\delta-$ число параметров предполагаемого распределения. Далее по таблице «Критические точки распределения $\chi^{2}$ » определяют $\chi_{\text {крит }}^{2}$ в соответствии с определённым уровнем значимости $\alpha$ и числу $k$. Если $\chi_{\text {набл }}^{2}<\chi_{\text {набл }}^{2}$, то гипотеза $H_{0}$ принимается, в противном случае - отвергается.

Рассчитаем выборочную среднюю:

$$
x_{b}=\frac{\sum x_{i} * n_{i}}{n}
$$

и среднее квадратичное отклонение

$$
\sigma_{b}(x)=\sqrt{D_{b}(x)}
$$

Затем найдем примерные значения числовых характеристик, соответствующих нормальному распределению:

$$
\begin{gathered}
\overline{\chi_{b}} \approx \frac{x_{\max }-x_{\min }}{2}, \\
\sigma_{b}(x) \approx \frac{x_{\max }-x_{\min }}{6}
\end{gathered}
$$

Поскольку расчеты приведены ниже, для обоснования дальнейших действий заметим, что во всех трех случаях распределение получилось предположительно нормальным.Далее используем следующие критерии для подтверждения гипотезы о нормальности распределения: Пирсона, Колмогорова, Романовского, числа Вестергарда, меру центральной тенденции, а также найдем доверительный интервал, асимметрию и эксцесс.

Доверительный интервал, в котором с вероятностью $p=1$ - $\alpha$ находится случайная величина $\overline{x_{b}}$, рассчитывается следующим образом:

$$
\mu-Z_{\alpha} * \frac{\sigma}{\sqrt{n}} \leq \bar{X} \leq \mu+Z_{\alpha} * \frac{\sigma}{\sqrt{n}}
$$

где $Z_{\alpha}$ - критическое значение стандартного нормального распределения для уровня значимости $\alpha=1-P$, которое можно найти в соответствующей таблице.

Для $\alpha=0,05$ это значение равно $\pm 1,96$, следовательно, доверительный интервал определяется по формуле: $\overline{x_{b}} \pm 1,96\left(\frac{\sigma}{\sqrt{n}}\right)$.

Асимметрия - показатель симметричности или скошенности кривой распределения - находится по следующей формуле:

$$
A=\frac{\sum_{i=1}^{n}\left(x_{i}-\bar{x}\right)^{3}}{n * \sigma^{3}} .
$$

При левосторонней асимметрии ее по-

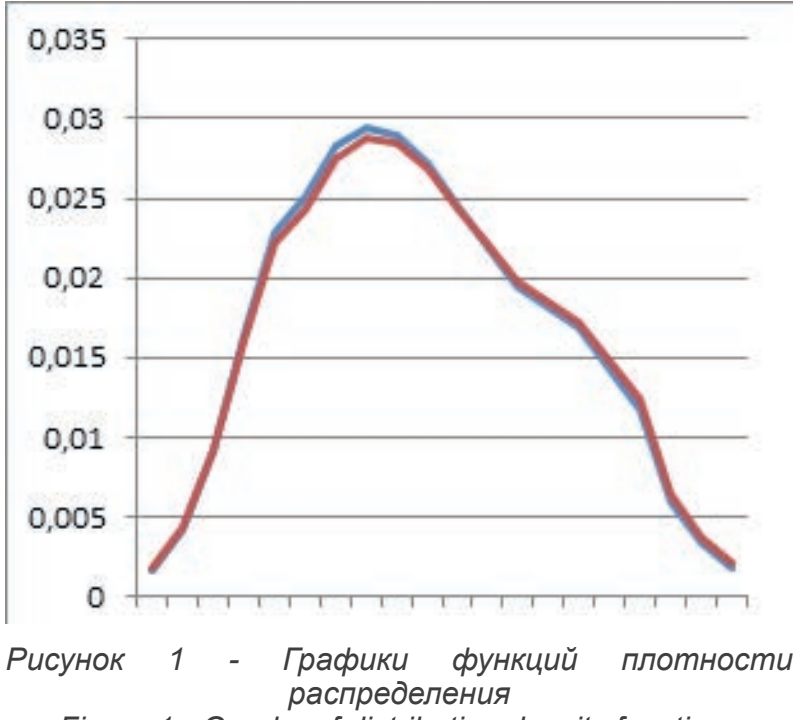

Figure 1 - Graphs of distribution density functions

казатель является положительным и в распределении преобладают более низкие значения признака. При правосторонней - показатель отрицательный и преобладают более высокие значения. Коэфффициент эксцесса - мера остроты пика распределения случайной величины. Если в распределении преобладают значения близкие к среднему арифметическому, то формируется островершинное распределение. В этом случае показатель эксцесса стремится к положительной величине. У нормального распределения эксцесс равен нулю. Если у распределения 2 вершины (бимодальное распределение), то эксцесс стремится к отрицательной величине. Показатель эксцесса определяется по формуле:

$$
E=\frac{\sum\left(x_{i}-\bar{x}\right)^{4}}{n * \sigma^{4}}-3 .
$$

Итак, сведем полученные расчеты в таблицу и проанализируем их относительно друг друга (табл.1).

Анализ полученных результатов показывает, что во всех трех случаях распределение является действительно нормальным, однако нужно заметить, что разное количество интервалов дает немного отличные друг от друга результаты.

Меньшее количество интервалов на гистограмме «сглаживает» результаты исследования, тем самым нивелируя нежелательные измерения, которые могут «выбиваться» из общей выборки и мешать статистическому анализу. Это можно видеть как раз на приведенных выше гистограммах. В обоих случаях мы имеем нормальное распределение с правосторонней асимметрией, однако, опираясь только на первый график, можно было предположить, что распределение бимодальное, несмотря на то 
Таблица 1. Итоговая сравнительная таблица Table 1. Final comparative table

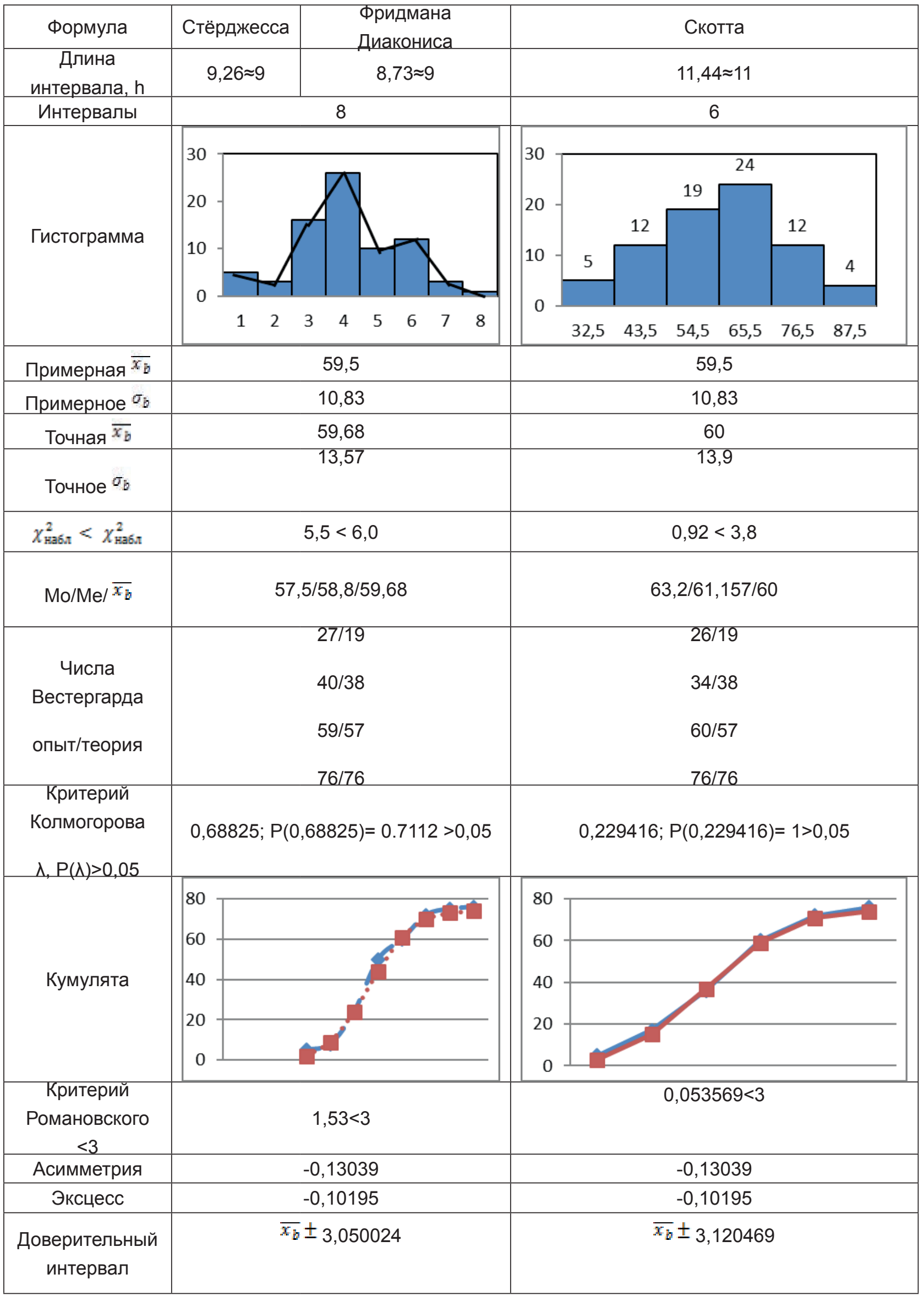


что дальнейшие расчеты подтверждали его нормальность. Подобные неточности могут запутать и усложнить статистический анализ.

Однако, если сравнить полученные функции плотности распределения, видно, что погрешность вычислений между двумя способами незначительна (не более 10\%).

В заключение можно сказать: представленное исследование показывает, что разница в вычислениях длины интервала вариационного ряда по различным формулам незначительна при анализе выборки небольшого размера. Для более точной оценки данных формул необходимы выборки размером более двухсот измерений, а для совокупностей элементов малых размеров каждая из трех представленных фрормул является справедливой.

\section{СПИСОК ЛИТЕРАТУРЫ}

1. Гмурман, В.Е. Руководство к решению задач по теории вероятностей и математической статистике: учебное пособие для студентов вузов/ В.Е.Гмурман. - 9-е изд., стер. - М: Высш. шк., 2004. - 404 с.

2. Кобзарь, А.И. Прикладная математическая статистика. Для инженеров и научных работников. - М.: ФИЗМАЛИТ, 2006. - 816 c.

3. Freedman, D. and Diaconis, P. (1981) On this histogram as a density estimator: L2 theory. Zeit. Wahr. ver. Geb., 57, 453-476.

4. Scott, D.W. (1979) On optimal and data-based histograms. Biometrika, 66, 605-610.

5. Sturges, H. (1926) The choice of a class-interval. J. Amer. Statist. Assoc., 21, 65-66.

6. Hyndman, R.J.(1995) The problem with Sturges' rule for constructing histograms, Department of Econometrics and Business Statistics, , Monash University, Clayton VIC 3800, Australia.

\section{REFERENCES}

1. Gmurman, V. E. Guide to solving problems in probability theory and mathematical statistics: a textbook for University students/ V. E. Gmurman. - 9th ed., erased. - M: Yes. SHK., 2004. - 404 PP.

2. Kobzar, A. I. Applied mathematical statistics. For engineers and scientists. - - M.: FIZMATLIT, 2006. - 816 PP.

3. Freedman, D. and Diaconis, P. (1981) On this histogram as a density estimator: L2 theory. Zeit. Wahr. ver. Geb., 57, 453-476.

4. Scott, D.W. (1979) On optimal and data-based histograms. Biometrika, 66, 605-610.

5. Sturges, H. (1926) The choice of a class-interval. J. Amer. Statist. Assoc., 21, 65-66.

6. Hyndman, R.J.(1995) The problem with Sturges' rule for constructing histograms, Department of Econometrics and Business Statistics, , Monash University, Clayton VIC 3800, Australia. 


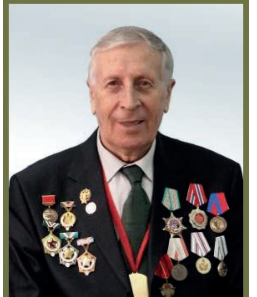

Ю. А. Масаев // Yu.A. Masaev

канд. техн. наук, профессор ФГОУ ВО КузГТУ им. Т.Ф, Горбачева

Почетный член Академии горных наук candidate of technical sciences, professor FGOU VO KuzGTU named after T.F. Gorbachev,

Honorary Member of the Academy of Mining Sciences

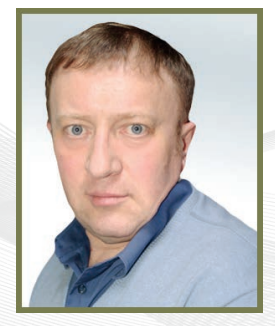

\section{B. Ю. Масаев// V.Yu. Masaev}

канд. техн. наук, доцент Кемеровская государственная сельскохозяйственная академия, кафедра ландшафтной архтектуры

candidate of technical sciences, associate professor

Kemerovo State Agricultural Academy, Department of Landscape Architecture

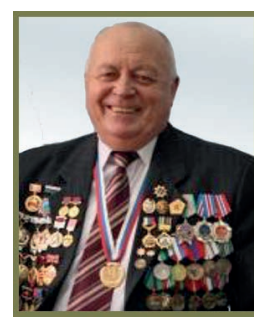

А.И. Копытов //A.I. Kopytov

доктор техн. наук, профессор ФГОУ ВО КузГТУ им. Т.Ф. Горбачева,

руководитель Сибирского отделения Академии горных наук

doctor of technical sciences, professor FGOU VO KuzGTU named after T.F. Gorbachev,

Leader of Mining Sciences Academy Siberian Branch

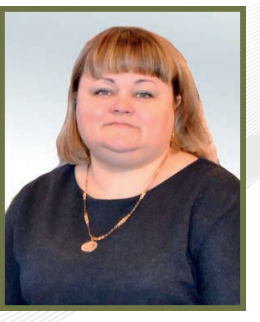

М.А. Яковченко // M.A. Yakovchenko

канд.техн..наук., доцент Кемеровская государственная сельскохозяйственная академия, кафедра ландшафтной архитектуры

candidate of chemical sciences, associate professor

Kemerovo State Agricultural Academy, Department of Landscape Architecture

УДК 338.439 (571.17)

\section{ВЛИЯНИЕ РАЗВИТИЯ УГЛЕДОБЫЧИИ НА ЭКОЛОГИЧЕСКУЮ ОБСТАНОВКУ В КУЗБАССЕ INFLUENCE OF COAL MINING DEVELOPMENT ON ENVIRONMENTAL CONDITIONS IN KUZBASS}

Рассмотрены основные причины загрязнения окружающей среды Кузбасса - крупнейшего угледобывающего региона Российской Федерации. Ежегодное увеличение добычи и переработки каменного угля наряду с повышением социально-экономического развития региона приводит к ухудшению экологической обстановки.

Дан анализ содержания токсичных веществ в газообразных продуктах взрыва при использовании взрывчатых веществ с различным кислородным балансом и их влияние на организм человека.

Представлены данные по запыленности воздушного пространства на рабочих местах.

На количество образующихся тонкоизмельченных пылевидных частиц влияют минералогический состав и фризико-механические свойства горных пород, свойства применяемых ВВ, порядок расположения и взрывания зарядов ВВ и др., и их необходимо учитывать при проектировании массовых взрывов.

Дана оценка токсичности вскрышных и вмещающих пород, размещаемых в породных отвалах и терриконах на угольных, рудных шахтах и угольных разрезах.

Отмечена одна из причин ухудшения экологической обстановки, связанная с проявлениями сейсмической активности и землетрясениями, и их взаимосвязь с производством массовых взрывов.

The main causes of environmental pollution of the Kuzbass, the largest coal-mining region of the Russian Federation, are considered. An annual increase in the extraction and processing of coal along with an increase in the socio-economic development of the region leads to a deterioration of the ecological situation.

The analysis of toxic substances' content in explosion gaseous products using explosives with different oxygen balances and their effect on the human body is given. Data on dustiness of airspace at workplaces are presented.

The amount of finely ground dust particles formed is influenced by the mineralogical composition and the physicomechanical properties of rocks, the properties of the explosives used, the explosive charges' arrangement and ignition, etc., and they must be taken into account when designing mass explosions.

The toxicity of overburden and host rocks placed in rock dumps and heaps at coal, ore mines and at coal opencast mines is estimated.

One of the reasons for the environmental degradation associated with the manifestations of seismic activity and earthquakes, and their connection with the production of mass explosions, is noted. 
КлючевЫе слова: ВЗРЫВЧАТЫЕ ВЕЩЕСТВА, ГАЗООБРАЗНЫЕ ПРОДУКТЫ ВЗРЫВА, УГОЛЬНЫЙ РАЗРЕЗ, МАССОВЫЙ ВЗРЫВ, ТЕРРИКОНЫ И ОТВАЛЫ, ВСКРЫШНЫЕ ПОРОДЫ, ТЕХНОГЕННАЯ ДЕЯТЕЛЬНОСТЬ, ЭКОЛОГИЯ, ЗЕМЛЕТРЯСЕНИЯ, МАГНИТУДА.

Key words: EXPLOSIVES; GASEOUS EXPLOSION PRODUCTS; COAL MINE; MASS EXPLOSION; WASTE HEAPS AND DUMPS; OVERBURDEN ROCKS; ANTHROPOGENIC ACTIVITY; ECOLOGY; EARTHQUAKES; MAGNITUDE.

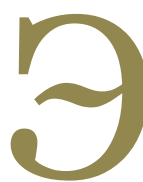

кологическая обстановка тесно связана с трудовой деятельностью человека и является исключительно важной и сложной. Она зависит от широкого комплекса социально-экономических, организационно-технических, медико-биологических и других вопросов, требующих научно-обоснованного решения. И на нее действуют как факторы производственной деятельности, так и непроизводственные факторы.

Процессы биологического взаимодействия стали замещаться процессами физического и химического взаимодействия, все более возрастающего характера и негативно влияющего как на человека, так и на природу.

Активная техногенная деятельность во многих регионах нашей планеты приводит к разрушению биосферы, создавая новый тип среды обитания - техносферу, и глобальное ухудшение экологической ситуации в мире все больше зависит от возросшей техногенной неустойчивости промышленных систем, процессов и технологий.

Техногенная деятельность человека резко обострила экологическую ситуацию. Нарастающие выбросы в воздушный бассейн пыли и газа приводят к изменению климата планеты, к снижению, а в некоторых случаях и полному разрушению озонового слоя атмосфреры и, как следствие, росту заболеваемости людей.

Исследователями было установлено, что за год в атмосфреру Земли выбрасывается около 2000 млн тонн окиси углерода, 150 млн тонн двуокиси серы, 53 млн тонн окислов азота, $120 \mathrm{mлн}$ тонн золы. И значительная доля этих выбросов приходится на отрасли производства, связанные с добычей полезных ископаемых, их транспортированием, переработкой и потреблением.

Безопасность и экологичность производственных процессов добычи полезных ископаемых должна обеспечиваться соблюдением требований промышленной безопасности, нормализацией микроклимата, уровней физических фракторов, содержания пыли и вредных веществ в воздухе рабочих мест и окружающей среде, ведением производственного контроля, соблюдением радиационной безопасности.

По оценкам специалистов мировое потребление минерального сырья достигло около 12 млрд тонн в год, а извлечение горных пород из недр ежегодно составляет около 100 млрд тонн.

На проходивших (г. Кемерово, 2011 г.) Международной научно-практической конференции и расширенном заседании Организационного комитета Всемирного горного конгресса была определена роль угля в экономике России и топливно-энергетическом балансе мира в XXI B. [1].

Согласно «Долгосрочной программе развития угольной промышленности России до 2030 года», представленной Министерством энергетики РФ, было намечено довести добычу угля в стране до 430 млн тонн в год, а в Кузбассе - до 260 млн тонн.

Кузбасс является крупнейшим угледобывающим бассейном России, где добывается более 60 \% угля от общего объема по стране.

Вместе с увеличением масштабов добычи и переработки минерального сырья наблюдается рост мощности единичного горного производства, под которым понимается концентрация добычи и переработки сырья в отдельных горнодобывающих и перерабатывающих предприятиях.

Добыча полезных ископаемых, строительных материалов, поделочных блоков ценных пород ведется с применением взрывных работ, и количество одновременно взрываемых зарядов ВВ бывает различное, отчего зависит объем образующихся ядовитых газов и пылевидных частиц. Примером может служить сооружение селезащитной Алма-Атинской плотины, минимальная высота которой составляла $71 \mathrm{~m}$, ширина по гребню 220 м, длина по руслу 730 м. Общий объем навала разрушенной породы должен был составлять от 4,35 до $5,48 \mathrm{mлн}$ м, $^{3}$ и для этого необходимо было взорвать заряд ВВ общей массой 9235 тонн.

Наибольшая по величине плотина была сооружена в конце XX в. для Камбаратинской ГЭС, высота которой составляла 300 м, длина 2800 м и объем в заданном профиле 135 млн м³. Не менее уникальным было сооружение взрывонабросной плотины Даштиджумского гидроузла, высота которой составляла 275 м, а длина по гребню 720 м [2]. Естественно, что при взрывном разрушении таких огромных масс горных пород в атмосферу выбрасывались значительные объ- 
емы газа и пыли. Но такие объекты сооружались нечасто и, можно сказать, были единичными по сравнению с разработкой угольных и рудных месторождений, которая ведется постоянно. Если в Кузбассе за год добыто 250 млн тонн угля, то сколько миллионов кубических метров горных пород необходимо разрушить и употребить взрывчатых веществ?

При добыче полезных ископаемых, в частности угля открытым способом, основными источниками загрязнения воздушного бассейна являются ядовитые газы и пыль, образующиеся при бурении скважин, взрывной подготовке пород и их экскавации, транспортировании горной массы, а также за счет сдувания тонкодисперсных частиц пыли с поверхности горных разработок и отвалов горных пород. При этом следует отметить, что количество мельчайшей пыли, поднятой с поверхности, пропорционально скорости ветра.

Из ядовитых газов взрыва особую опасность представляют окислы азота и углерода. Любое взрывчатое вещество состоит из четырех основных химических элементов, но с разным числом атомов $-\mathrm{C}_{c} \mathrm{H}_{\mathrm{h}} \mathrm{O}_{\mathrm{o}} \mathrm{N}_{\mathrm{n}}$, и имеющийся в составе кислород должен окислить эти элементы до конечных продуктов ( $\mathrm{CO}_{2}, \mathrm{H}_{2} \mathrm{O}, \mathrm{NO}, \mathrm{NO}_{2}$ и др.). (Детонация ВВ может проходить даже в безвоздушном пространстве). Но не всегда реакция окисления проистекает одинаково, и это зависит от содержания кислорода в составе ВВ (кислородного баланса). Кислорода может не хватать для полного окисления всех горючих компонентов (отрицательный кислородный баланс), и в этом случае недоокисленные компоненты, попадая в атмосфреру воздуха, начинают доокисляться с выделением большого количества тепла образуются вторичные реакции окисления, которые могут вызвать воспламенение (или взрыв) пылегазовой взрывоопасной атмосферы.

На рис. 1 представлены результаты киносъемки (со скоростью до 10000 кадров /сек) взрыва зарядов ВВ с отрицательным кислородным балансом. На первых кадрах виден ореол светящихся газообразных продуктов взрыва (ПВ), выбрасываемых из шпура (скважины), который сначала увеличивается в объеме (распыляется), а затем все более и более уменьшается и полностью исчезает, затухая (второй столбец на рис.), через некоторое время свечение вновь появляется, увеличиваясь в объеме, происходят вторичные окисления недоокисленных продуктов детонации с выделением большого количества тепла, которое может вызвать вспышку взрывоопасной атмосфреры.
Такое явление особо опасно при разработке месторождений полезных ископаемых подземным способом, когда в рудничной атмосфере присутствует метан $\left(\mathrm{CH}_{4}\right)$ и другие взрывоопасные пылегазовые смеси, взрыв которых, особенно в угольных шахтах, неоднократно приводил к крупным авариям с гибелью людей.

Во взрывчатых веществах с положительным кислородным балансом после окисления в процессе детонации, входящих в состав ВВ компонентов, остается лишний кислород, и вместе с газообразными продуктами взрыва он попадает в атмосфреру. Но в атмосфрере более $20,99 \%$ его не должно быть, и кислород вступает в реакцию с азотом, образуя самые вредные для организма человека соединения $\mathrm{NO}$ и $\mathrm{NO}_{2}$. В подземных горных выработках эти окислы и так содержатся в образованных при взрыве зарядов ВВ газообразных ПВ, а затем в атмосфере выработки происходит еще и дополнительное их образование. Содержание окислов азота свыше допустимой нормы приводит к отравлению рабочих.

При массовых взрывах на открытых горных работах образуется огромное облако пыли и газа. Пылевидные частицы при соответствующих условиях способны подняться на высоту до 300 м, а затем оседают на поверхность окружающей местности. Газовое облако способно подняться на высоту до 4000 м, азотные соединения, попадая в зону дождевых облаков, образуют азотную кислоту и выпадают на больших площадях в виде кислотных дождей, нанося ущерб сельскохозяйственным угодьям.

Приведенные отрицательные показатели взрывчатых веществ с положительным и отрицательным кислородным балансом не наблюдаются у взрывчатых веществ с нулевым кислород-

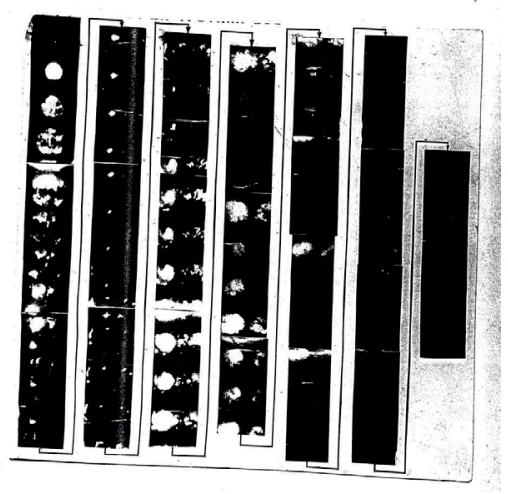

Рисунок 1. Кинограмма выброса из шпура (скважины) высокотемпературных ПВ и развитие вторичных реакций в атмосфере

Figure 1. The film record of high-temperature $P V$ outburst from the borehole (well) and secondary reactions development in the atmosphere 
ным балансом, когда в составе ВВ нет избытка и недостатка кислорода. Но создать практически такие ВВ сложно. От теоретического расчета до процесса изготовления, хранения, транспортирования и применения проходит достаточно много времени, и во взрывчатом веществе могут произойти различные непредвиденные изменения с соответствующим изменением его свойств.

Особую опасность из ядовитых газов взрыва представляют окись углерода и окислы азота. Содержание этих газов в продуктах взрыва у тротилосодержащих ВВ и простейших (без тротила) различно. Если содержание окислов азота у тех и других ВВ почти одинаково, то содержание окиси углерода после взрыва тротилосодержащих ВВ в 2-4 раза больше, чем у простейших (например, у игданита). При этом у тротилосодержащих ВВ их содержание наименьшее, когда кислородный баланс близок к нулевому (рис. 2).

При производстве взрывных работ с использованием простейших ВВ (например, игданит), в составе которых присутствует дизельное топливо, количество ядовитых газов будет зависеть от процентного содержания дизельного топлива в их составе (рис. 3).

Количество жидкого топлива в составе ВВ влияет и на такие показатели, как теплота взрыва, скорость детонации и чувствительности к внешним воздействиям ВB.

Теплота взрыва и скорость детонации смеси аммиачной селитры и жидкого топлива достигает своих максимальных значений при его содержании около 6 \% общей массы, что соответствует приближенно нулевому кислородному балансу. Наибольшее количество ядовитых газов выделяется при взрывании тротила, из

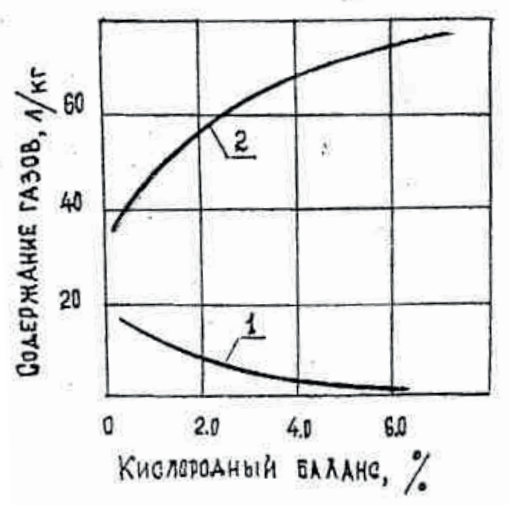

Рисунок 2. Зависимость содержания окислов углерода (1) и азота (2) в продуктах взрыва тротилосодержащих ВВ от кислородного баланса Figure 2. Dependence of carbon oxides (1) and nitrogen (2) content in the TNT-containing explosives' blast products on the oxygen balance

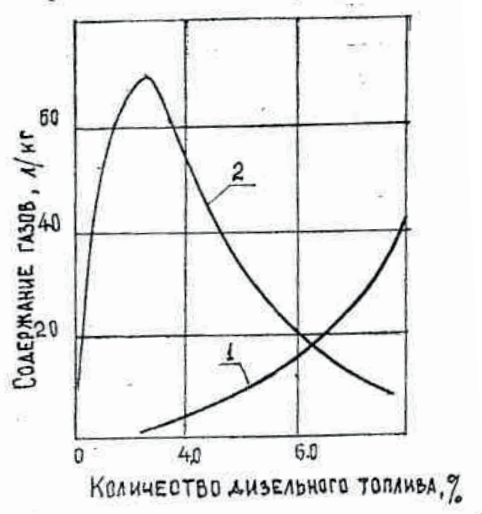

Рисунок 3. Зависимость содержания окислов углерода

(1) и азота (2) от количества жидкого

(2) топлива в составе простейших $B B$

Figure 3. The dependence of carbon oxides (1) and nitrogen (2) content on the amount of liquid fuel in the simplest explosives' composition

них только одной окиси углерода 84,4 л/кг ВВ. Общее количество окиси углерода при взрыве достигает 100 л/кг и азота до 8 л/кг ВВ. Ядовитые газы после взрыва остаются и в разрушенной породе, и в течение длительного времени продолжают из нее выделяться. Так, наиболее ядовитые окислы азота могут задерживаться в атмоссрере до 15 дней и за это время способны переноситься ветром на расстояние более 1000 км. При этом в воздушных массах, содержащих пары воды, окислы азота и серы образуют кислотные дожди.

Объем выбросов в атмосферу газообразных продуктов и пыли зависит от объемов обуренной и взорванной горной массы, расхода взрывчатых веществ на разрезах, угольных и рудных шахтах Кузбасса. Перечень выпускаемых взрывчатых веществ достаточно широк, но наибольшую долю в этом перечне занимают тротилосодержащие ВB, и расход взрывчатых веществ растет в связи с ежегодным увеличением объемов переработки горной массы и увеличением удельного расхода ВВ в связи с возрастанием прочностных характеристик горных пород при переходе на более глубокие горизонты, что в конечном итоге приводит к значительному увеличению объемов выброса ядовитых газов. Ежегодное увеличение объема выделений вредных газов на горнодобывающих предприятиях Кузбасса составляет 15-20 \% , и за год объем выделения вредных газов достигает более 25 млн. м³.

Одним из путей снижения вредных выбросов в атмосферу явилось производство эмульсионных взрывчатых веществ бинарного типа, применение которых позволило сократить содержание окислов азота и углерода в выбрасываемых 
газообразных продуктах взрыва и за счет этого существенно снизить экологическую нагрузку на окружающую среду.

Кроме газообразных продуктов взрыва, в атмосферу выбрасывается огромное количество тонкоизмельченных пылевидных частиц. Известно, что до 25 процентов энергии ВВ затрачивается на дробление породы в ближней от зарядов BВ зоне, и чем выше бризантность применяемых взрывчатых веществ, тем больше образуется тонкоизмельченных пылевидных частиц.

Количество выбрасываемой при массовом взрыве пыли достигает 17 кг/м³ взорванной породы. В зависимости от фризико-химических свойств горных пород при взрывании зарядов ВВ массой 1 т образуется от 70 до 400 кг пыли и 32-

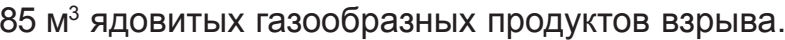
Максимальные концентрации пыли превосходят в 3-4 раза предельно допустимые нормы, и их содержание зависит от удельного расхода используемых взрывчатых веществ и схемы расположения скважин, минералогического состава горных пород и степени обводненности взрываемого массива.

В общем объеме пылеобразования значительная часть приходится на процесс бурения скважин для размещения зарядов ВВ, при котором до 30 \% всей выбуренной породной мелочи (буровой штыб) составляют мельчайшие частицы, и их количество зависит от фризико-механических свойств горной породы. Как правило, вся выбуренная пылевидная мелочь остается на поверхности взрываемого уступа угольного разреза и в момент взрыва скважинных зарядов ВВ поднимается в воздух вместе с взорванной породной массой, что и создает значительный прирост запыленности воздушного бассейна.

Анализ объемов добычи угля в Кузбассе с 2009 г. (181,3 млн т) по 2018 г. (255,3 млн т) (рис. 4) показал, что в общем объеме добычи в 2015 г. в 2 раза увеличились объемы добываемого открытым способом угля, при этом возросли объемы бурения скважин, расход ВВ, взрываемой горной массы, а значит, и объем выбросов пылевидных частиц в атмосферу. Общий объем загрязняющих выбросов в атмосферу по Кузбассу только за 2017 г. составил 813, 9 тыс. тонн или 65 \% общего объема выбросов [7, 8]. В Кузбассе добычей угля занимаются 42 шахты и 51 разрез. На подземных работах добыча угля с применением взрывных работ ежегодно снижалась, а на угольных разрезах за счет приоритетности и их развития неуклонно повышалась.

При добыче угля открытым способом образование пылевидных частиц с интенсивно- стью до десятков грамм в секунду происходит при выполнении всех основных технологических процессов, и в некоторых зонах содержание пыли превышает предельно допустимые нормы в 10-100 раз [8]. При этом, дисперсность образующейся пыли очень высокая - до 90 процентов пылинок имеют диаметр 10 мкм и менее. Мелкие фракции (меньше 50 мкм) поднимаются вверх и уносятся воздушными потоками за пределы выемочного участка, загрязняя атмосферу, а более крупные остаются в пределах разреза и загрязняют рабочее пространство.

Рабочее пространство угольных разрезов имеет свои специфические особенности, и это особенно сказывается в глубоких разрезах. В Кузбассе глубина угольных разрезов достигает 370 м. Известно, что с увеличением глубины разреза скорость воздушного потока для проветривания рабочего пространства снижается в 2-7 раз, а температура повышается на 1-2 градуса на каждые 100 м, и температура в кабинах работающих экскаваторов, буровых станков и т.п. достигает более $35^{\circ} \mathrm{C}$ в летнее время.

Загрязнение атмосфреры происходит не только за счет добычи полезных ископаемых открытым или подземным способом, но и при транспортировке различными видами транспорта, переработке добытой горной массы на обогатительных фрабриках и др.

Переработка угля на обогатительных фабриках с каждым годом увеличивается. Так, по России в 2000 г. на обогатительных фрабриках перерабатывалось 84,6 млн т угля, а в 2017 г. уже 191,2 млн т, что составляет 50 \% от всего добываемого угля [9]. В Кузбассе действует 54 обогатительные фабрики, и обогащению подвергается также большое количество добываемого угля как подземным, так и открытым способом. Обогатительные фабрики выполняют двоякую роль: с одной стороны, улучшают качество добытого угля за счет удаления примесей пустых пород, а с другой стороны, засоряют воздушный бассейн этими удаленными пустыми породами. В выбросах обогатительных фабрик содержатся породы крупных размеров частиц, которые поступают затем в отвалы пустых пород, и породы мелких фракций с размером частиц до 30 мкм, причем в этой среде до 50 \% содержится частиц с размерами до 10 мкм [10]. Такие частицы в сточных водах попадают в речные бассейны и отравляют воду, используемую для сельского хозяйства и в бытовых целях.

Источниками выбросов загрязняющих веществ в атмосфреру являются породные отвалы пустых пород на угольных и рудных шахтах, 


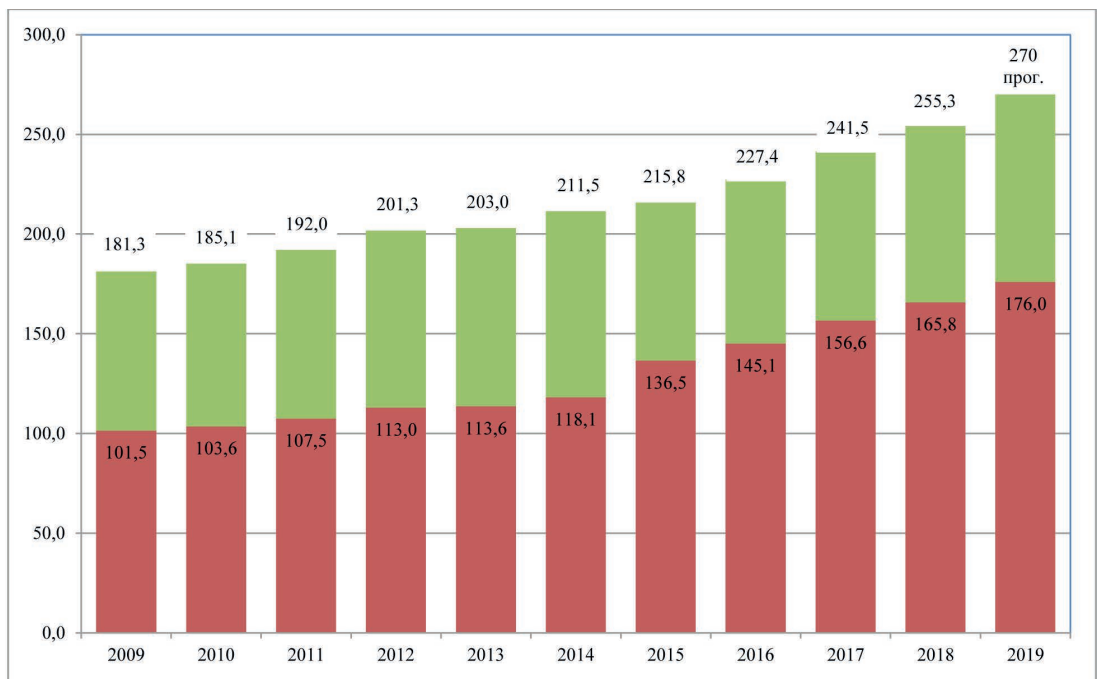

Рисунок 4. Динамика роста добычи угля в Кузбассе и в России с 2009 г. по 2018 г.

Figure 4. Growth dynamics in coal production in Kuzbass and in Russia from 2009 to 2018

особенно на угольных разрезах, создающих серьезные геоэкологические проблемы. В 2013 г. на территории Кузбасса скопилось 2661,28 млн т отходов производства и потребления, из них 97,5 \% (2953,78 млн т) - отходы, получаемые при добыче угля и горючих сланцев [10]. А на территории России к 2016 г. в отвалах горных пород угледобывающих предприятий скопилось около 12 млрд т, на 1 января 2018 г. было размещено уже более 17 млрд т вскрышных и вмещающих горных пород [7]. Отвалы вскрышных пород угольных разрезов занимают огромные площади земельных угодий, нанося вред развитию сельского хозяйства, отравляя почву, водные бассейны и т.д. Но не меньший вред наносится и воздушному бассейну. В отвалах горных пород содержится большое количество различных минералов, различного состава и свойств, которые с течением времени вступают в химические реакции и образуют дополнительные отравляющие продукты, поступающие в атмосферу.

При добыче угля подземным способом в отвалы (терриконы) поступает большое количество породы, выдаваемое из шахт со значительным содержанием угля, присутствие которого приводит к реакциям самовозгорания с образованием различных по токсичности соединений. А терриконы, как правило, находятся вблизи жилых районов, и населению приходится дышать этим воздухом. Но угольные шахты дают еще и другие выбросы загрязняющих веществ в атмосфреру, в частности выбросы газа метана $\left(\mathrm{CH}_{4}\right)$. По количеству выделяемого метана на тонну суточной добычи угля шахты разделены на категории опасности. В Кузбассе почти все шахты отнесены к III категории и сверхкатегорным. К шахтам III категории отнесены те, в которых на тонну суточной добычи выделяется от 10 до 15 $\mathrm{M}^{3}$ метана, а в сверхкатегорных - свыше $15 \mathrm{~m}^{3}$, а это может быть и 16 м $^{3}$ и 50 м $^{3}$ или более. Поэтому можно представить, сколько выделилось метана, если в 2017 году в Кузбассе добыча угля подземным способом составила 89 млн т, открытыми работами разрабатываются те же самые угольные пласты, и если общая добыча угля в 2017 г. была 241,5 млн т, то сколько же метана поступило в атмосферу. Загрязнение воздушного бассейна отрицательно влияет на здоровье людей. По данным Всемирной организации здравоохранения в мире ежегодно умирает до 7 миллионов человек по причине загрязнения воздуха в помещениях и в атмосфере [11].

Кроме упомянутых причин ухудшения экологической обстановки, Кузбасс к тому же является еще и сейсмически неблагоприятным субъектом Российской Федерации, и это в какой-то степени связано не только с геологическим залеганием горных пород, но и с производством массовых взрывов при добыче полезных ископаемых [12-18]. В этом отношении особое место занимает Беловский район, где в 2013 г. произошло достаточно активное землетрясение с магнитудой более 5 баллов в районе деятельности самого глубокого угольного разреза «Бачатский». В 2014 г. в Беловском районе произошло 69 землетрясений, в 2015 г. - 45 землетрясений, а за 8 месяцев 2016 г. - 50 землетрясений различной активности вблизи 21 населенного пункта. А 30.07.2018 г. произошло землетрясение с магнитудой 4,1 балла в 84 км от г. Кемерово.

По временам года число землетрясений было неравномерное, наибольшее число происходило в весеннее время (35\%), в летнее и осеннее время по $25 \%$, а в зимнее время наи- 
меньшее число (15\%). По интенсивности все землетрясения были почти одинаковыми с магнитудами 2,5-2,7 баллов, максимальные достигали 3,5-3,7 баллов, а минимальные - 2,1-2,5 баллов.

Примечательно то, что многие зарегистрированные землетрясения происходили в дни производства массовых взрывов на угледобывающих разрезах Беловского района. Например, в 2015 г. таких землетрясений зафиксировано 28, а не связанных с массовыми взрывами более 16. И совершенно иное было зафиксировано в 2016 г. Как уже было отмечено, за 8 месяцев этого года произошло 50 землетрясений, из них 48 произошли в дни производства массовых взрывов. При этом все зафиксированные землетрясения происходили в один и тот же период дневного времени - с 12.00 до 16.00 часов, магнитуда землетрясений была почти в одинаковых пределах - от 2,0 до 3,5 баллов.

Землетрясения представляют собой сложные явления, связанные со строением внутренних зон Земли и происходящих в них процессов и утверждать, что причиной землетрясений послужило производство массовых взрывов однозначно нельзя. В земных недрах постоянно происходит бесконечное разнообразие изменений: кристаллизация минералов; вулканическая деятельность и другие формы магнетизма; образование, изменение и разрушение горных пород; деформация пород в процессе складчатости и формирование разрывов; неоднородное нако- пление тепла под земной корой, вызывающее непосредственное изменение объема за счет сжатия или расширения, сопровождающееся разрывами и подвижкой плит, изменяющими внутренне строение Земли. И такие процессы происходят в земных недрах непрерывно.

Кемеровская область по географическому расположению насыщена горными хребтами и котловинами, что предопределяет наличие сложного ландшафта, геологических разломов, разнообразие горных пород и минералов с различными фризико-механическими свойствами, глубинных процессов преобразования структурных элементов, что и может быть причиной сейсмических проявлений.

Климатические условия расположения Кемеровской области препятствуют рассеиванию загрязняющих веществ в воздухе, и за счет этого большая часть промышленных выбросов осаждается в Кузнецкой котловине и на обращенных к ней склонах гор. Все это приводит к увеличению числа дней, неблагоприятных для рассеивания выбросов по метеоусловиям до 95 дней в году. Наибольшая масса вредных выбросов приходится на все угледобывающие города Кузбасса, и это приводит к высокой заболеваемости населения. Поэтому охрана здоровья и окружающей среды является важной составляющей качества жизни населения, и показатели развития экологической защиты имеют непосредственную зависимость от уровня экономического развития региона.

\section{СПИСОК ЛИТЕРАТУРЫ}

1. Масаев, Ю. А. Экологическая обстановка и продовольственная безопасность промышленного Кузбасса / Ю. А. Масаев, Т. П. Дорофеева, Т. В. Фролова, А. Б. Коржун // Вестник научного центра по безопасности работ в угольной промышленности. Выпуск 3. ООО «ВостЭКО». - Кемерово, 2015. - С. 85-91.

2. Копытов, А. И. Взрывные работы в горной промышленности А. И. Копытов, Ю. А. Масаев, В. В. Першин. - Новосибирск : «Наука», 2013. - 511 с.

3. Масаев, Ю. А. Анализ загрязнения атмосферы при производстве буровзрывных работ на угольных разрезах Ю. А. Масаев, И. А. Паначев // Вопросы безопасности взрывных работ на угольных предприятиях. Сб. науч. тр. ВостНИИ, № 2. - Кемерово, 1993. - С. 39-43.

4. Масаев, Ю. А. Основные причины загрязнения воздушного бассейна при разработке угольных месторождений Кузбасса и направления по их снижению / Ю. А. Масаев, И. А. Паначев // Экологические проблемы горного производства. Тр. Всероссийской научной конференции. - Москва, 1995. C. $244-261$.

5. Масаев, Ю. А. Воздействие угледобычи на экологическую обстановку в Кузнецком бассейне / Ю. А. Масаев, И. А. Паначев // Проблема создания экологически чистых и ресурсосберегающих технологий добычи полезных ископаемых и переработки отходов горного производства. Тр. I Международной конференции. - Тула, 1996. C. $77-78$

6. Паначев, И. А. Влияние буровзрывных работ, применяемых при угледобыче на экологическую обстановку в Кузбассе / И. А. Паначев, Ю. А. Масаев // Актуальные вопросы подземного и наземного строительства. Сб. науч. тр. КузГТУ. - Кемерово, 1996. - С. 96-103.

7. Трушина, Г.С.Влияние угольной промышленности Кузбасса на экологическую и продовольственную безопасность региона. - журнал «Уголь», № 10, 2018. - С. 98-101.

8. Кузнецов, Д. А. Комплексные решения проблемы пылеобразования на угольных разрезах Кузбасса / Д. А. Кузнецов, Р. Р. Минибаев, Н. Н. Ахлестин, С. В. Спирин. // Вестник научного центра по безопасности работ в угольной промышленности. Выпуск 3. ООО «ВостЭКО». - Кемерово, 2016. - С. 64-71.

9. Тарзанов, Г. И. Итоги работы угледобывающей промышленности России за январь-июнь 2018 г. - журнал «Уголь», № 10, 2018. - С. 47-59 
10. Журавлева, Н. В. Методы оценки влияния процессов добычи и переработки углей Кузнецкого угольного бассейна на экономическое состояние природной среды / Вестник научного центра по безопасности работ в угольной промышленности. Выпуск 4. ООО «ВостЭКО». - Кемерово, 2016. - С. 102-112.

11. Харионовский, А. А. Оценка влияния на окружающую среду открытого и подземного способов добычи угля / А. А. Хариновский, А. Р. Литвинов, М. Ю. Данилов, Т. Махмуд // Вестник научного центра по безопасности работ в угольной промышленности. Выпуск 4. ООО «ВостЭКО». - Кемерово, 2016. C. $113-118$.

12. Масаев, Ю. А. Массовые взрывы при добыче угля открытым способом и их влияние на сейсмические проявления в Кузбассе / Ю. А. Масаев, А. И. Копытов, В. Ю. Масаев, С. Е. Ильина // Вестник научного центра по безопасности работ в угольной промышленности. Выпуск 4. ООО «ВостЭКО». - Кемерово, 2016. - С. $48-57$.

13. Яковлев, Д. В. Генезис и развитие природно-техногенной сейсмоактивности Кузбасса / Д. В. Яковлев, Т. И. Лазаревич, С. В. Цирель. - журнал «Уголь», № 10, 2013. - С. 53-59.

14. Еманов, А. Ф. Техногенная сейсмичность разрезов Кузбасса (Бачатское землетрясение 18 июня 2013 г.) / А. Ф. Еманов, А. А. Еманов, А. В. Фатеев и др. // Физико-технические проблемы разработки полезных ископаемых, № 2, 2014 - С. 41-46.

15. Цирель, С. В. Взаимосвязи между сейсмической активностью в Кузбассе и ведением открытых горных работ / С. В. Цирель, А. А. Павлович // Записки горного института, Т-198, 2013. - С. 174-179.

16. Машуков, И. В. Регистрация сейсмических колебаний от подземных массовых взрывов / Горный информационно-аналитический бюллетень, № 4, 2014. - С. 216-221.

17. Машуков, И. В. Регистрация сейсмических колебаний от воздействия подземных массовых взрывов на Таштагольском месторождении / И. В. Машуков, В.П.Доманов, А. А. Семин, А. Г. Серг, М. А. Климкин // Вестник научного центра по безопасности работ в угольной промышленности. Выпуск 4. ООО «ВостЭКО». - Кемерово, 2015. - C. 24-29.

18. Бычков, С. В. Химические реакции в процессе землетрясений. Взрыв пород горного массива как источник толчков, внезапных выбросов и горных ударов / Вестник научного центра по безопасности работ в угольной промышленности. Выпуск 4. ООО «ВостЭКО». - Кемерово, 2016. - С. 36-47.

\section{REFERENCES}

1. Masaev, Yu.A., Dorofeev, T.P., Frolova, T.V., \& Korzhun, A.B. (2015). Ekologicheskaia obstanovka i prodo-volstvennaia bezopasnost promysh-lennogo Kuzbassa [Ecological situation and food safety of the industrial Kuzbass]. Vestnik nauchnogo tsentra po bezopasnosti rabot v ugolnoi promyshlennosti - Herald of Safety in Mining Industry Scientific Center, 3, 85-91 [in Russian].

2. Kopytov, A.I., Masaev, Yu.A., \& Pershin, V.V. (2013). Vzryvnyye raboty v gornoi promyshlennosti [Blasting works in mining].Novosibirsk: Nauka [in Russian].

3. Masaev, Yu.A., \& Panachev, I.A. (1993). Analiz zagrwazneniwa atmosfery pri proizvodstve burovzryvnykh rabot na ugolnykh razrezakh [Analysis of air pollution during the drilling and blasting operations at coal mines]. Voprosy bezopasnosti vzryvnykh rabot na ugolnykh predpriyatiyakh - Safety issues of explosive operations in coal mines, collection of scientific works VostNII, Kemerovo, 2, pp. 39-43 [in Russian].

4. Masaev, Yu.A., \& Panachev, I.A. (1995). Osnovnyie prichiny zagriaznenia voz-dushnogo basseina pri razrabotke ugolnykh mestorozhdeni Kuzbassa i napravlenia po ikh snizheniu [The main causes of air pollution in the development of Kuzbass coal deposits and directions for their reduction]. Proceedings from: Environmental issues of mining. AllRussian Scientific Conference. (pp.244-261). Moscow, [in Russian].

5. Masaev, Yu.A., \& Panachev, I.A. (1996). Vozdeystvie ugledobychi na ekologicheskuiu obstanovku v Kuznetskom basseine [Environmental impact of coal mining in the Kuznetsk basin]. Proceedings from: The problem of creating environmentally friendly and resource-saving technologies for mining and mining waste processing. I International Conference (pp. 77-78) Tula [in Russian].

6. Panachev, I.A., \& Masaev, Yu.A. (1996). Vliyanie burovzryvnykh rabot, primeniaiemykh pri ugledobyche na ekologicheskuiu obstanovku v Kuzbasse [The impact of drilling and blasting operations used in coal mining on the environmental situation in Kuzbass]. Aktualnyie voprosy podzemnogo i nazemnogo stroitelstva - Actual issues of underground and surface construction. Collection of KuzGTU scientific works, Kemerovo, pp. 96-103[in Russian].

7. Trushina, G.S. (2018). Vlianie ugolnoy promyshlennosti Kuzbassa na ekologicheskuiu i prodovolstvennuiu bezopasnost regiona [The influence of the Kuzbass coal industry on the environmental and food security of the region.]. Ugol Coal, 10, 98-101 [in Russian].

8. Kuznetsov, D.A., Minibaev, R.R., Akhlestin, N.N., \& Spirin, S.V. (2016). Vestnik nauchnogo tsentra po bezopasnosti rabot v ugolnoi promyshlennosti - Herald of Safety in Mining Industry Scientific Center, 3, 64-71 [in Russian].

9. Tarzanov, G.I. (2018). Itogi raboty ugledobyvaiushchei promyshlennosti Rossii za ianvar-iun $2018 \mathrm{~g}$. [The results of the coal mining industry of Russia activity for January-June 2018]. Ugol - Coal, 10, 47-59 [in Russian].

10. Zhuravleva, N.V. (2016). Metody otsenki vliania protsessov dobychi i pererabotki uglei Kuznetskogo ugolnogo basseina na ekonomicheskoie sostoianie prirodnoi sredy [Methods for assessing the impact of coal mining and processing processes in the Kuznetsk coal basin on the economic condition of the environment]. Vestnik nauchnogo tsentra po bezopasnosti rabot v ugolnoi promyshlennosti - Herald of Safety in Mining Industry Scientific Center, 4, $102-112$ [in Russian].

11. Kharinovsky, A.A., Litvinov, A.R., Danilov, M.Yu., \& Makhmud, T. (2016). Otsenka vliania na okruzhaiushchuiu sredu otkrytogo i podzemnogo sposobov dobychi uglia [Environmental impact assessment of open and underground coal mining]. Vestnik nauchnogo tsentra po bezopasnosti rabot v ugolnoi promyshlennosti - Herald of Safety in Mining Industry Scientific Center, 4, 113-118 [in Russian].

12. Masaev, Yu.A., Kopytov, A.I., Masaev, V.Yu., \& Iliina, S.Ye. (2016). Massovyie vzryvy pri dobyche uglia otkrytym sposobom i ikh vlianie na seismicheskie proiavleniia $v$ Kuzbasse [Mass explosions during open cast coal mining and their impact on seismic manifestations in Kuzbass]. Vestnik nauchnogo tsentra po bezopasnosti rabot v ugolnoi 
promyshlennosti - Herald of Safety in Mining Industry Scientific Center, 4, 48-57 [in Russian].

13. Yakovlev, D.V., Lazarevich, T.I., \& Tsyrel, S.V. (2013). Genezis i razvitie prirodno-tekhnogennoi seismoaktivnosti Kuzbassa [Genesis and development of natural-technogenic seismic activity of Kuzbass]. Ugol - Coal, 10, 53-59 [in Russian]

14. Yemanov, A.F., Yemanov, A.A., \& Fateev, A.V. et al. (2014). Tekhnogennaia seismichnost razrezov Kuzbassa (Bachatskoie zemletriasenie 18 iuna 2013 g.) [Technogenic seismicity of the Kuzbass opencast mines (Bachat earthquake on June 18, 2013)]. Fiziko-tekhnicheskie problemy razrabotki poleznykh iskopaiemykh - Physical and technical problems of mining, 2, 41-46 [in Russian].

15. Tsirel, S.V., \& Pavlovich, A.A. (2013). Vzaimosviazi mezhdu seismicheskoi aktivnostiu v Kuzbasse i vedeniem otkrytykh gornykh rabot [Relationships between seismic activity in Kuzbass and opencast mining]. Mining Institute Notes, V. 198, pp. 174-179 [in Russian].

16. Mashukov, I.V. (2014). Registratsia seismicheskikh kolebani ot podzemnykh massovykh vzryvov [Registration of seismic vibrations from underground mass explosions]. Gorny informatsionno-analiticheskii biulleten - Mining Informational Analytical Bulletin, 4, 216-221 [in Russian].

17. Mashukov, I.V., Domanov, V.P., Semin, A.A., Serg, A.G., \& Klimkin, M.A. (2015). Registratsia seismicheskikh kolebani ot vozdeistvia podzemnykh massovykh vzryvov na Tashtagolskom mesto-rozhdenii [Registration of seismic fluctuations from the effects of underground mass explosions at the Tashtagol deposit]. Vestnik nauchnogo tsentra po bezopasnosti rabot v ugolnoi promyshlennosti - Herald of Safety in Mining Industry Scientific Center, 4, 24-29 [in Russian].

18. Bychkov, S.V. (2016). Khimicheskie reaktsii v protsesse zemletryaseni. Vzryv porod gornogo massiva kak istochnik tolchkov, vnezapnykh vybrosov i gornykh udarov [Chemical reactions during earthquakes. Explosion of rocks of a massif as a source of bumps, sudden outbursts and rock shocks]. Vestnik nauchnogo tsentra po bezopasnosti rabot v ugolnoi promyshlennosti - Herald of Safety in Mining Industry Scientific Center, 4, 36-47 [in Russian].

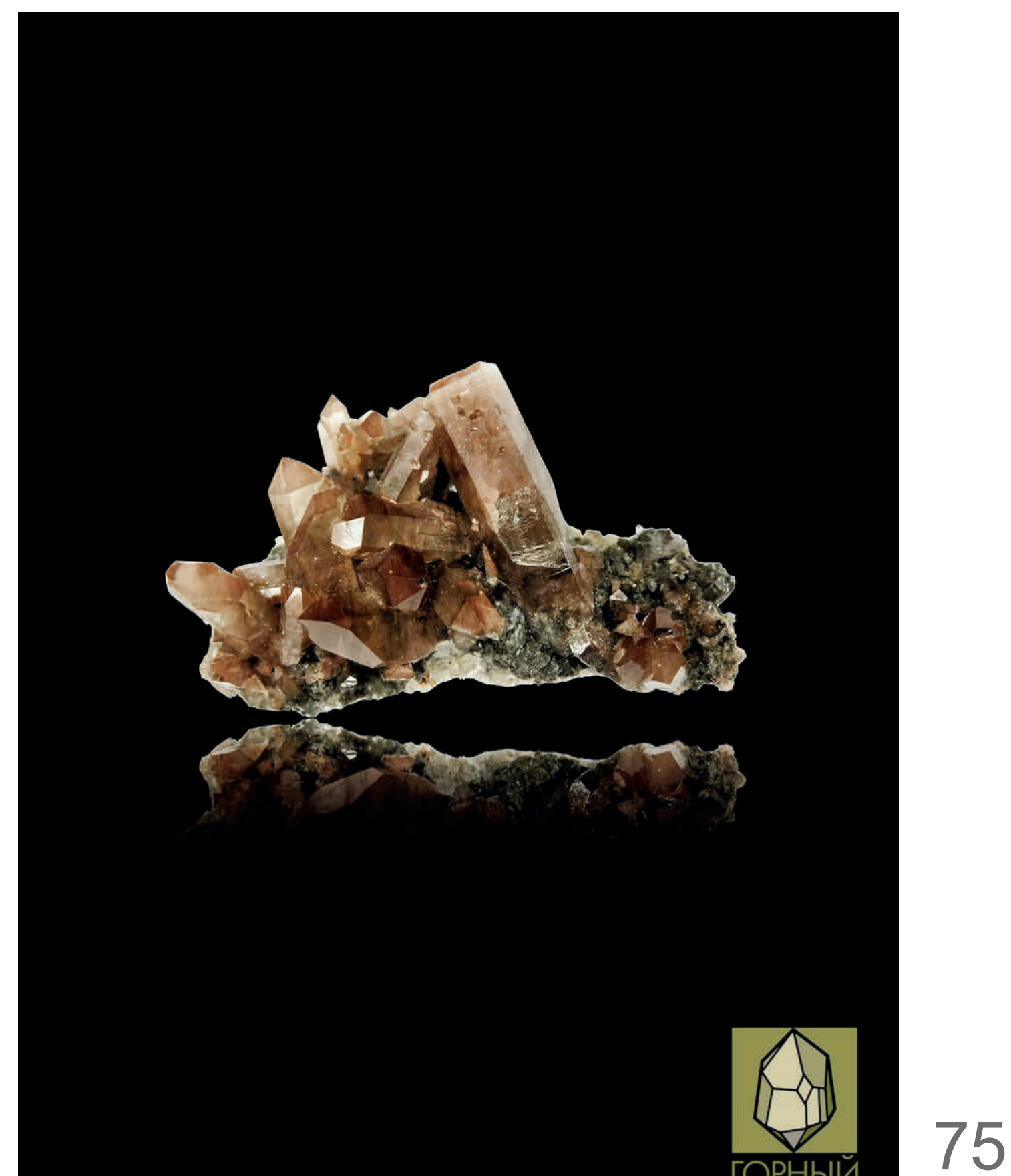




\section{IV. ПРОБЛЕМЫ И СУЖДЕНИЯ IV. PROBLEMS AND OPINIONS}

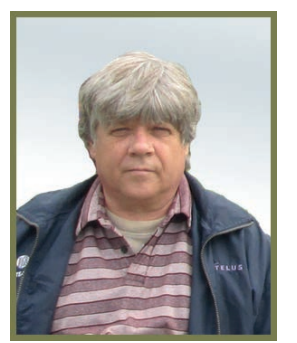

С.Б. Бычков// S.V. Bychkov sergueibychkov@gmail.com

горный инженер, Университет

Британской Колумбии, Ванкувер,

Канада

mining engineer University of British

Columbia, Vancouver, Canada

удк

\section{ЭНЕРГИЯ ЗЕМЛЕТРЯСЕНИЙ И ЗАКОНЫ ГИДРОДИНАМИКИ EARTHQUAKE ENERGY AND THE LAWS OF HYDRODYNAMICS}

Фундаментом изложенного в статье материала служит свойство жидкости при движении по трубопроводу создавать гидравлический удар. Каналы, разломы и трещины в земной коре можно отнести к подземным "трубопроводам", а магму к жидкости. Следовательно, при движении магмы в земной коре и мантии происходят гидравлические удары. Возникающие при этом процессе ударные волны образуют энергетические импульсы, которые сопровождаются мгновенными перепадами температур, давлений, ускорений и торможений атомов, фразовыми переходами материи и роем землетрясений. Находясь в рамках теории господина Рейда - Упругая отдача ответить на вопрос образования роя землетрясений невозможно, а современная геофизика нерешительно обвиняет в этом магму, которая якобы изменяет температурный фрон земной коры, тем самым вызывая объёмное расширение пород и подземные толчки. Мы находим это объяснение правильным, но недостаточным. По нашему мнению механизм образования роя землетрясений заключается $в$ энергии гидравлических ударов магмы при её движении в разломах и трещинах пород.

The insoluble circle of the most complicated issues that arose when predicting and explaining the causes of earthquakes from the standpoint of the classic theory of Elastic recoil by Mr. Reid plunged the scientific world of seismologists into deep pessimism, clearly expressed by the decision of the U.S. Congress to stop funding earthquake prediction programs as a waste of money. The world of geophysics has come close to recognizing the fact that over more than a century of history, the Reid theory has shown its complete failure and primitivism. It became obvious to the scientific community that it is impossible to explain the causes of the catastrophic movements of the earth's crust by the laws of classical mechanics and elastic forces, and the time has come to join the efforts of various scientific discipline representatives to solve the problems of geophysics. The ideological and practical basis of this article was the work of numerous groups of physicists and chemists [1], which give theoretical and experimental results on obtaining condensed plasma, or the so-called warm dense substance (WDS) in the world's leading laboratories. The hypothesis based on the possibility of natural forces not only to form a condensed plasma in the bowels of our planet, but also with WDS to carry out thermonuclear fusion - muon - catalyzed fusion ( $\mu \mathrm{CF}$ ) reactions [2, 3, 4] with the possibility of transition of the process to nuclear reactions, "under the uranium blanket" and in the process of a catastrophic earthquake formation is presented in the article. Shown are models of deep focus, shallow focus and volcanic earthquakes.

Ключевые слова: ГИДРАВЛИЧЕСКИЙ УДАР, ЗЕМЛЕТРЯСЕНИЕ, РОЙ ПОДЗЕМНЫХ ТОЛЧКОВ, МАГМА

Key words: HYDRAULIC SHOCK, EARTHQUAKE, QUAKE SWARM, MAGMA.

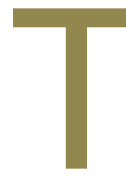

еоретическая часть.

Рой землетрясений может возникнуть при землетрясениях различного рода.

В данной работе мы исследуем возникновение роя землетрясений при двух видах сейсмических проявлений: тектонических и вулканических.

Рой тектонических землетрясений.

Рассмотрим механизм образования роя подземных толчков на примере тектонических 
землетрясений 1870 года в южной Греции. Рассматриваемая территория расположена на стыке Афрриканской и Евразийской тектонических плит, между которыми расположена малая Эгейская плита, на южной части которой и находится Греция. Эгейская плита движется в юго-западном направлении относительно Евразийской плиты, подминая под себя Африканскую плиту. Землетрясение, захватившее Фокиду, Эвбее, Аттику, Пелопоннес, началось 29 июля 1870 года со слабых толчков на острове Лисса. К вечеру 31 июля сейсмическая активность заметно усилилась, и в 3 часа ночи 1 августа греческую землю потряс сильнейший толчок. Его сопровождали сильные колебания и вращательные движения грунта. Все это длилось почти 20 минут. За это время были разрушены Дельфы, Кси-ропидаги, Хриссо, Итеа, а также Арахова и Анфисса. После этого землетрясение, говоря медицинским языком, перешло в хронический лихорадочный озноб земной поверхности! Бывали дни, когда в местечке Итеа за сутки происходило от 1700 до 2000 ударов. В некоторые дни колебания почвы происходили каждые 3 секунды! В общей сложности за три года у эпицентра произошло около 86 тысяч колебаний и ударов. Попробуем разобраться, как фракт роя подземных толчков может соотноситься с теорией «Упругой отдачи»? По теории господина Рейда, землетрясение возникает в момент скольжения пород тектонических плит относительно друг друга или вдоль разлома, движению которых препятствует сила трения. Вследствие этого энергия, вызывающая движение, накапливается в форме упругих напряжений пород. Когда напряжение достигает критической точки предельной прочности пород, происходит резкий разрыв пород с их взаимным смещением. Накопленная энергия, освобождаясь, вызывает волновые колебания поверхности земли - землетрясения [1]. Если следовать в фарватере идей господина Рейда, то в нашем случае первые подземные толчки Греческого землетрясения однозначно продемонстрировали, что критическая точка предельной прочности пород пройдена, Африканская плита потеряла устойчивость и начала своё движение под Эгейскую плиту. Но почему после этого момента возникло ещё 86 тысяч толчков? По сути это должно означать, что критических точек было 86 тысяч, которые последовательно преодолевались Африканской плитой в течение 3 лет по нескольку тысяч точек в день? Это абсолютно нереально. Рассмотрим другое возможное объяснение, вытекающее из теории господина Рейда, когда Эгейская тектоническая плита в результате раз- вития систем взаимодействующих трещин просто вспарывалась с образованием разлома, крылья которого, смещаясь из первоначального положения, генерировали сейсмические волны. Но это ещё более непонятный момент в нашем случае, ибо невозможно придумать причину, которая бы заставила Эгейскую тектоническую плиту 86 тысяч раз взмахивать крыльями разлома с частотой в несколько секунд в течение 3 лет! Как мы видим, и это направление исследований роли упругих сил в процессе землетрясений оказывается лишено смысла. Остаётся один путь объяснения причин роя подземных толчков - это воздействие на породы земной коры раскалённой магмы, о которой, как о причине роя подземных толчков, очень осторожно говорит современная сейсмология. Но в этом случае мы обязаны выйти из рамок объяснения землетрясений теорией господина Рейда и забыть про энергию упругих деформаций, которая якобы годами и веками накапливается тектоническими плитами и блоками! Следует добавить, что явление роя подземных толчков не является редким событием [2], такие явления в истории нашей планеты происходили и происходят регулярно и особенно часто при извержении вулканов, что ещё более тесно связывает нашу гипотезу гидравлических ударов с появлением и движением в глубинах Земли потоков магмы. К примеру, явление роя подземных толчков было отмечено в октябре 2006 года в заливе Фонсека, воды которого омывают Гондурас, Никарагуа и Сальвадор. Здесь за сутки произошло 691 землетрясение. Более 500 землетрясений и толчков произошло в течение двух недель в феврале 2008 года около города Мехикали, Мексика. В 2014 году область земли вблизи границ штатов Калифорния, Орегон и Невада пережила более чем 800 подземных толчков в течение трех месяцев. В 2017 году филиппинская провинция Батангас испытала рой землетрясений (800 толчков).

Секрет механизма образования роя подземных толчков удалось раскрыть благодаря способности жидкого тела преобразовывать кинетическую энергию движущего потока в потенциальную энергию при внезапном прекращении движения. Можно сказать больше, согласно расчетам в работе [3] гидравлические удары магмы могут привести к образованию в недрах планеты плазмы, которая сама по себе в момент разлёта может вызвать сейсмические волны большой мощности, фразовые переходы веществ и другие реакции. История гласит, что гидравлический удар [4] как фризическое явление известен с далёкого 1898 года, когда русский учёный Н.Е. 
Жуковский исследовал это терроризирующее весь мир явление и описал его в своей работе. Стоило людям закрыть или открыть в доме водопроводный кран - водоподводящая труба лопалась со всеми вытекающими из этого неприятного события хлопотами. Жуковскому удалось найти ответ: что происходит с водопроводными трубами, которые, казалось бы, без всяких на то причин каждый день в любом городе мира постоянно рвутся, словно сделаны не из нового и прочного, а прогнившего металла. С тех пор учёные изучили явление гидравлического удара до мельчайших подробностей, придумали для его нейтрализации различные обратные клапаны, установили их на трубах и навсегда забыли эту проблему. На этом история изучения и борьбы с гидравлическими ударами бы и закончилась, если бы сегодня вдруг не выяснилось, что явление гидравлического удара вот уже более ста лет хитро маскирует свою причастность к механизму образования землетрясений и является одной из причин подземных толчков! Возникает закономерный вопрос: каким образом гидравлический удар относится к землетрясениям и в чём его сейсмический секрет? Гидравлический удар как фризическое явление [4] - это почти мгновенный скачок давления в системе, заполненной жидкостью, достигающий при определённых условиях чудовищной величины. В основном, это явление вызывается быстрым изменением скорости потока жидкости в трубопроводе вследствие резкого закрытия или открытия крана. Городские водопроводные системы ничем не отличаются от сотворённых природой систем естественных подземных разломов, каналов и трещин, по которым течёт магма и которые внезапно могут быть перекрыты сместившимися блоками. И тут и там течёт жидкость в виде воды и магмы, молекулы которых двигаются с определённой внешними условиями скоростью. Следовательно, никакой разницы в физике процесса нет, ибо магма - это та же жидкость, а каналы, трещины и разломы в породах массива - это обыкновенные магмаподводящие "трубы”. Вся разница заключается в том, что в отличие от людей природа оказалась не способной установить на подземных “трубопроводах" обратные клапаны и другие устройства, компенсирующие силу гидравлического удара. Из этого вытекает однозначный вывод: в глубинах Земли случались, случаются и будут случаться гидравлические удары различной мощности. Одни удары могут быть слабые, другие - серьёзно потревожить человечество, а третьи - вызвать рой подземных толчков. Вопрос возможности гидравлических ударов в раз- ломах, трещинах и различных каналах упирается в вопрос строения Земли и наличия в структурах коры и мантии необходимого количества подвижной магмы, способной с достаточной скоростью перемещаться по трещинам и всевозможным каналам, и наличие “подземных трубопроводов" достаточных размеров для пропуска магмы. Согласно современным представлениям геофизиков, жидкая магма присутствует в мантии в небольших количествах в магматических камерах вулканов на относительно небольших глубинах, следовательно, как утверждают сейсмологи, серьёзные гидроудары в мантии Земли невозможны. Геофизики утверждают, что основной объём магмы в коре и мантии находится в виде твёрдого тела, и только малая часть мантии - астеносфера - представляет собой сильно вязкий расплав. При этом учёные ссылаются на данные сейсморазведки, а именно на непроходимость S волн сквозь жидкие среды. На этом единственном факте строится теория строения Земли и покоится фрундамент геофизики. Но существуют многочисленные фракты, указывающие на то, что подвижная магма может находиться в коре и мантии Земли в виде некоторого количества маленьких и больших бассейнов с её перетеканием из одного подземного хранилища в другие, которые ввиду их незначительных размеров по сравнению с размерами Земли попросту неразличимы для S волн. Это подтверждается таким существенным фактом, как наличие в земной коре Батолитов[5], объёмы которых могут достигать $1.8^{*} 10^{15} \mathrm{~m}^{3}$. (Андский батолит). Очевидно, что если раньше природа могла образовывать огромные бассейны магмы, то почему она не может образовывать такие объёмы в мантии сегодня? А вот что нам говорит о подземной структуре подвода магмы к жерлу вулкана Толбачик и о движении магмы по “подземным трубам" один из главных специалистов мировой геофизики по вулканам и магматической геологии академик РАН господин Н.Л.Добрецов [6]: “...в вулканической структуре присутствуют несколько очагов магмы, между которыми все время идет непрерывный обмен веществом. Изменения в вышележащем очаге всегда связаны с изменениями в другом, более глубинном очаге, вплоть до того, что пять таких очагов могут работать как единая проточная колонна ...". То есть, перефразируя слова члена Российской Академии Наук на язык специалиста по гидродинамике, жидкая магма свободно перемещается по подземным проточным колоннам из одного бассейна магмы в другой на большие расстояния с сохранением всех фризических свойств жидкого 


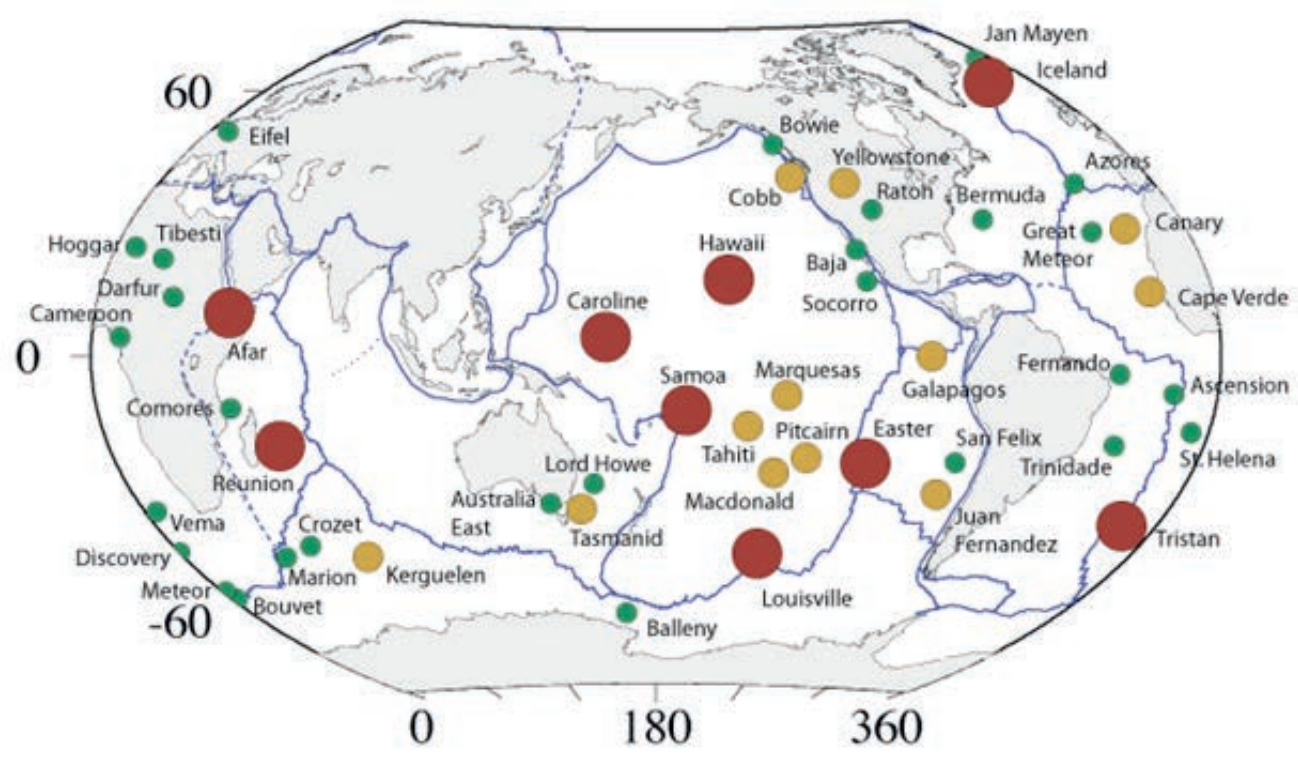

Рисунок 1. Горячие точки планеты. Круги красного цвета наиболее активные точки Figure 1. Hot spots of the planet. The red circles are the most active points.

тела. Следовало бы также сказать и о способности магмы подниматься из глубин мантии по каналам Горячих точек [7], способных выдавать на поверхность огромные массы магмы, ярким примером которых является Гавайская точка. На рис.1 показаны наиболее известные Горячие точки планеты.

Также можно привести образец мантийных плюмов на примере Йеллоустонского супервулкана. Известен интересный факт, показывающий, что магма может путешествовать по подземным магистралям на десятки, а возможно, и на сотни километров. Так 19 сентября 2017 года в Мексике произошло землетрясение с эпицентром в 55 километрах от вулкана Попокатепетль. В момент подземного толчка на вершине вулкана появилась вспышка, после чего вулкан выстрелил в атмосфреру газы в виде пара, дыма и пепла. Очевидно, что выхлоп вулкана был связан с ударной волной магмы, которая за несколько секунд прошла по подземным магистралям 55 км. Хорошо известно, что жидкая магма может образоваться из раскалённых блоков тектонических плит в результате сброса давления при их подвижках. Анализируя изложенные фракты можно сказать, что жидкой магмы, способной вызвать гидравлический удар в глубинах Земли, имеется достаточное количество, и запрет гидравлического удара, связанный с якобы отсутствием необходимого количества жидкой магмы в глубинах Земли, отсутствует. Естественно, магма в первую очередь будет присутствовать в зонах разломов тектонических плит, подъёмов, субдукций, спрединга, сдвигов, ибо там происходят резкие сбросы давлений, изменения темпе- ратур и огромные скачки напряжений. Особенно ярко это проявляется в так называемом Огненном кольце по краям Тихоокеанской тектонической плиты. Именно там расположены вулканы и происходят значительное количество всех землетрясений. Существует подозрение, что магма путешествует тысячи километров по подземным каналам Огненного кольца (рис. 2), отмечаясь гидравлическими ударами в различных его местах в виде землетрясений!

Исходя из физико-химических условий существования материи в недрах Земли, модель образования роя подземных толчков, а также отдельных землетрясений будет выглядеть так: гидравлический удар магмы, при изначальном большом давлении и высоком температурном фоне на глубине очага землетрясения, где вещества уже находятся и приобретают экстремальные и экзотические свойства и претерпевают необычные метаморфические и магматические транссрормации, ставит окружающие породы в экстремально неравновесные условия. Энергия ударной волны гидроудара вызовет мгновенный скачок давления и разогрев и так уже довольно горячих пород и магмы в районе события на сотни и тысячи градусов, а следовательно, мгновенное увеличение объёма окружающих пород. Кроме того, во время гидроудара вследствие малой сжимаемости магмы и высокой жёсткости окружающих пород скачок давления будет воздействовать практически на весь объём, участвующий в процессе, то есть сконцентрирует всю кинетическую энергию, которой обладал поток магмы и объёмы которой могут быть довольно значительны. Мгновенное повышение давления 


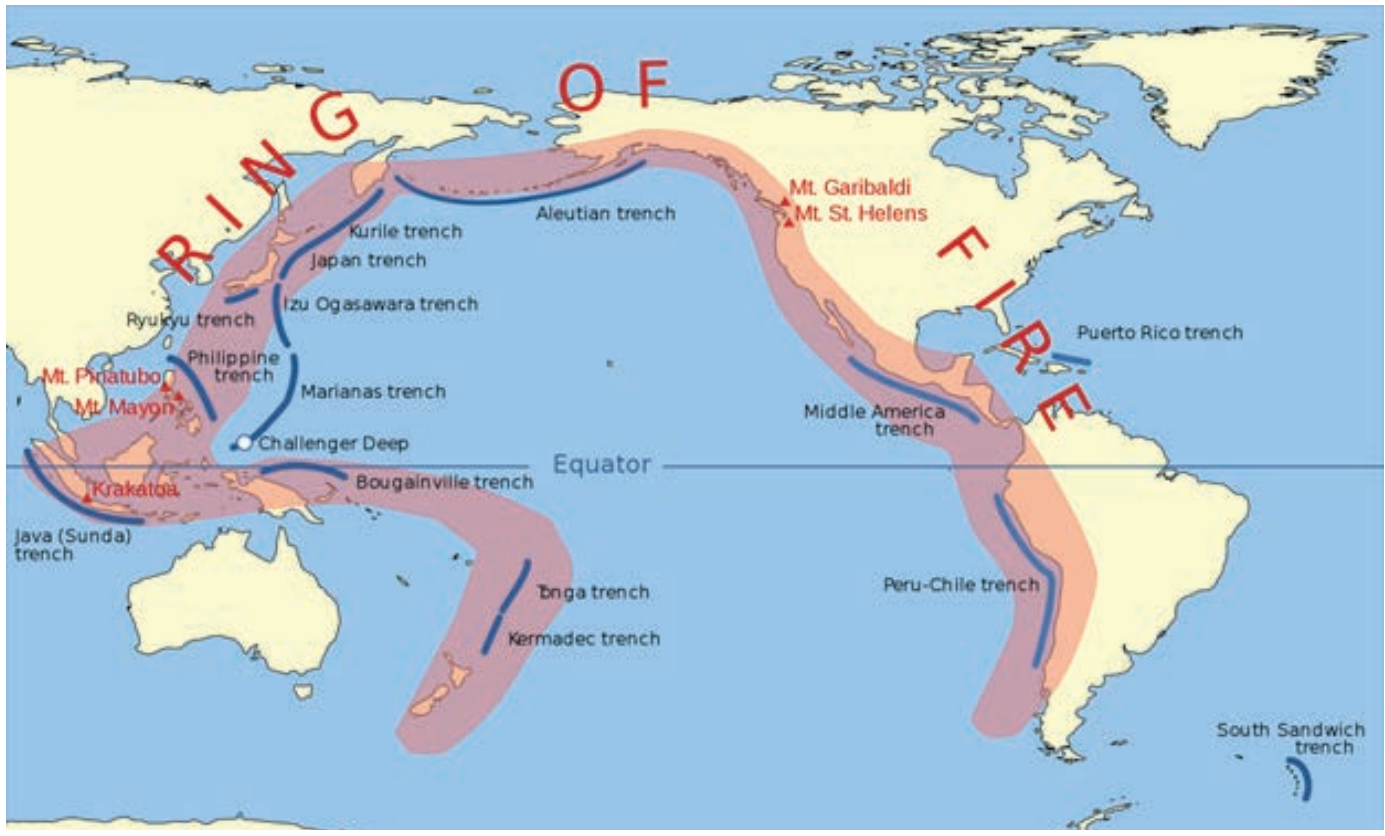

Рисунок 2. Огненное кольцо

Figure 2. Ring of fire

возможно на тысячи атмосфер, и таким резким скачкам давления будут соответствовать гигантские ускорения и торможения частичек вещества при прохождении через них фронта ударной волны, которая будет смещать породные блоки, создавая из них или разрушая пробки в мантийных каналах. Каждый последующий гидравлический удар будет вызывать дальнейшую дестабилизацию и разрушение породного массива, образование новых пробок, которые будут перекрывать трещины и разломы, создавая последовательно цепочку (рой) толчков.

В соответствии с расчетной формулой Жуковского, энергия гидравлического удара будет зависеть от минерального состава магмы, плотности, состава окружающих пород, параметров движения магмы и его объема. Пользуясь этой простой формулой, не только специалист по гидродинамике, но и любой человек легко рассчитает параметры скачка давления при гидравлическом ударе:

$$
\Delta P=\rho \cdot \Delta v \cdot C
$$

где $\Delta P$ - скачок давления; $\rho$ - плотность жидкости; $\Delta v$ - изменение скорости жидкости; $C$ - скорость распространения ударной волны.

В качестве примера воздействия ударной волны на земную кору определим выброс кинетической энергии гидравлического удара в произвольно выбранной трещине с небольшими размерами. Расчёт кинетической энергии потока жидкости:

$$
E_{\mathrm{k}}=\frac{m v^{2}}{2}
$$

где $m$ - масса потока магмы, $v$ - скорость потока магмы.

Примем поперечное сечение разлома $-D$ $=100 \mathrm{M}^{2}$, длину потока магмы (разлома) $-L=5000$ м. скорость потока магмы - $v=2 м / c$. удельную плотность магмы - $\rho=3000 \kappa 2 / \mathrm{m}^{3}$.

$m=D \cdot L \cdot \rho=100 \mathrm{M}^{2} \cdot 5000 \mathrm{M} \cdot \cdot 3000 \mathrm{\kappa} / \mathrm{M}^{3}=1500000$ $000 \kappa 2$.

$E_{k}=150000000 \cdot 2^{2} / 2=3000000000$ Дж.

1 к. ТНТ $=4,184 \cdot 10^{6}$ Дж

Эквивалент выделенной энергии, выраженный через ТНТ, будет равен:

$E_{k} / 4,184 \cdot 10^{6}$ Дж $=3000000000$ Дж. $/ 4184000$ Дж. $=\underline{717 \kappa 2 .}$

При сравнении данных, приведённых в расчётной таблице американской сейсмической лаборатории (The Nevada Seismological Laboratory) [8] (таблица 1) с полученным нами значением эквивалента ТНТ 717 кг., получается, что эта цифра соответствует сейсмическому толчку $M_{I}$ 1,5-2,0, что соответствует взрыву большого заряда взрывчатки в каком-либо карьере.

Отвечая на второй вопрос о возможности гидравлического удара в недрах Земли, связанного с наличием "подземных трубопроводов" достаточных размеров, мы хотели бы привести в качестве примера "подземных трубопроводов" хорошо известные геологам образования - Дайки. Это геологическое понятие означает вертикально стоящее (или близкое к вертикали) интрузивное геологическое тело застывшей магмы, ограниченное параллельными стенками и секущее вмещающие породы. Мощность дайки изменяется от долей до сотен и даже тысяч метров, протяжённость от 1 метра до 500 кило- 
Таблица 1. Величина Рихтера для сейсмического примера

Table1. Richter magnitude for seismic example

\begin{tabular}{|c|c|c|}
\hline \multicolumn{2}{|c|}{ Richter TNT for Seismic } & \multirow{2}{*}{$\begin{array}{l}\text { Example } \\
\text { (approximate) }\end{array}$} \\
\hline Magni & Energy Yiel & \\
\hline-1.5 & 6 ounces & Breaking a rock on a lab table \\
\hline 1.0 & 30 pounds & Large Blast at a Construction Site \\
\hline 1.5 & 320 pounds & \\
\hline 2.0 & 1 ton & Large Quarry or Mine Blast \\
\hline 2.5 & 4.6 tons & \\
\hline 3.0 & 29 tons & \\
\hline 3.5 & 73 tons & \\
\hline 4.0 & 1,000 tons & Small Nuclear Weapon \\
\hline 4.5 & 5,100 tons & Average Tornado (total energy) \\
\hline 5.0 & 32,000 tons & \\
\hline 5.5 & 80,000 tons & Little Skull Mtn., NV Quake, 1992 \\
\hline 6.0 & 1 million tons & Double Spring Flat, NV Quake, 1994 \\
\hline 6.5 & 5 million tons & Northridge, CA Quake, 1994 \\
\hline 7.0 & 32 million tons & Hyogo-Ken Nanbu, Japan Quake, 1995 \\
\hline 7.5 & 160 million tons & Landers, CA Quake, 1992 \\
\hline 8.0 & 1 billion tons & San Francisco, CA Quake, 1906 \\
\hline 8.5 & 5 billion tons & Anchorage, AK Quake, 1964 \\
\hline 9.0 & 32 billion tons & Chilean Quake, 1960 \\
\hline 10.0 & 1 trillion tons & (San-Andreas type fault circling Ear \\
\hline 12.0 & 160 trillion tons & (Fault Earth in half through center \\
\hline
\end{tabular}

метров (рис. 3). Например, всемирно известная Великая дайка Зимбабве. Она возвышается над окружающей местностью на 50-300 м, протягиваясь на 560 километров при мощности от 3,2 до 12,3 км (рис. 4). Можно легко подсчитать тот гигантский уровень энергии, который может образоваться при гидроударе магмы в системе крупных дайк, жил, трещин и тектоническом разломе. Следовательно, никаких запретов на возникновение гидравлических ударов, связанных с магматическими каналами в недрах Земли, не существует.

Рой землетрясений вулканического характера. Принципиально рои землетрясений вулканического характера ничем не отличаются от роя землетрясений тектонического характера. Это те же гидравлические удары, вызванные движением магмы по каналам в недрах Земли. Главной характерной особенностью роя вулканических землетрясений является изменение глубины их очагов с чётко выраженным уменьшением глубины. Если при тектоническом рое землетрясений глубина их очагов остаётся примерно на одной глубине, то согласно наблюдениям вулканологов за извержениями вулканов при вулканическом рое глубина очагов землетрясений всё время уменьшается. И это легко

объясняется постепенным поднятием магмы к земной поверхности по путям миграции, и дополнительно подтверждает связь движения магмы по каналам с образованием гидравлических ударов.

Из многочисленных геологических источников известно, что вулканы обладают разветвлённой подземной сетью подводящих каналов, трещин, дайк, которые в силу своих размеров и большого давления магмы могут пропускать через свои сечения большие объёмы расплавленных пород. Причём, согласно вышеприведённому исследованию [6], магма может поступать в корневую систему вулкана из различных бассейнов с различным химическим и фризическим составом магм и разными скоростями излияния (рис.5), где 3 - главное жерло вулкана; 1,2,4,5 боковые жерла; 6 - магматический очаг или несколько очагов; 7 - подводящие каналы; 8 - граница Мохоровича; 9 - зона основного плавления пород, значок молнии - гидравлический удар.

\section{Заключение}

В результате воздействия гидравлического удара в породах земной коры возникнет неравновесное состояние пород в месте удара и скачком увеличится кинетическая энергия движения молекул с хаотическим их распре- 


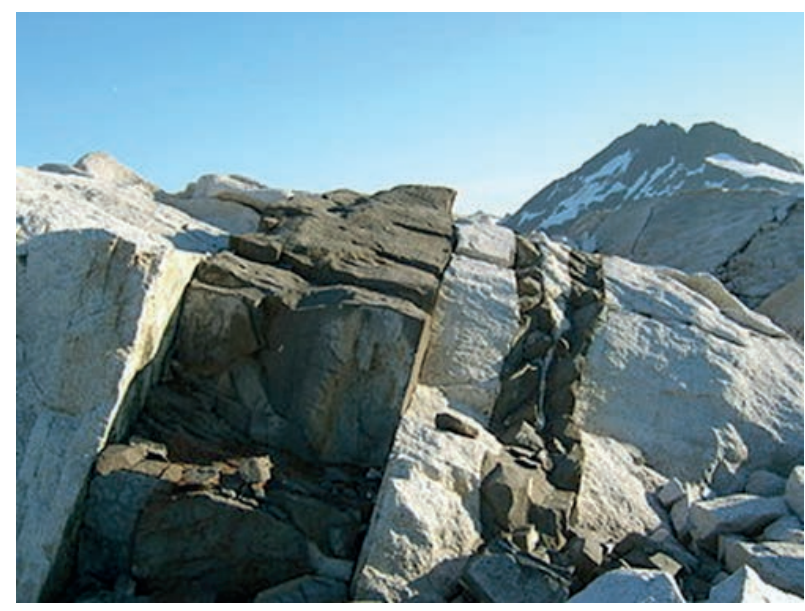

Рисунок 3. Три дайки на Baranof Cross-Island Trail, Аляска.

Figure 3. Three dykes at Baranof Cross-Island Trail, Alaska.

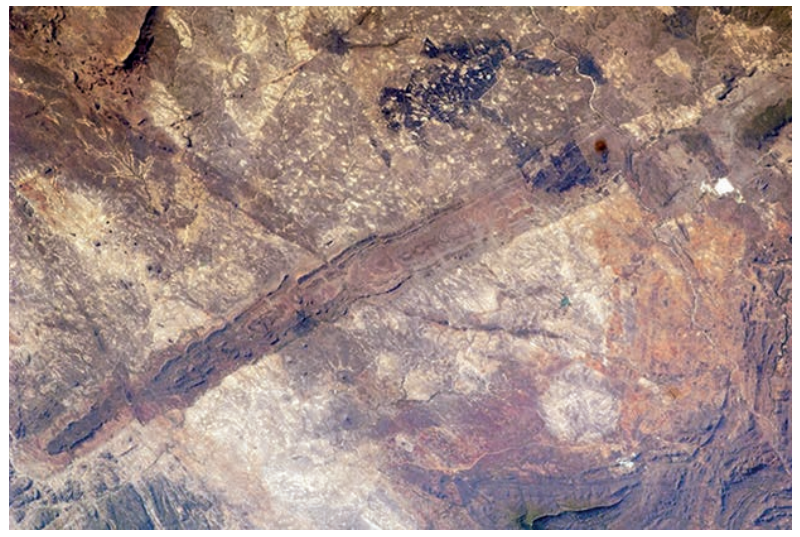

Рисунок 4. Великая дайка Зимбабве Figure 4. Great Dyke Zimbabwe

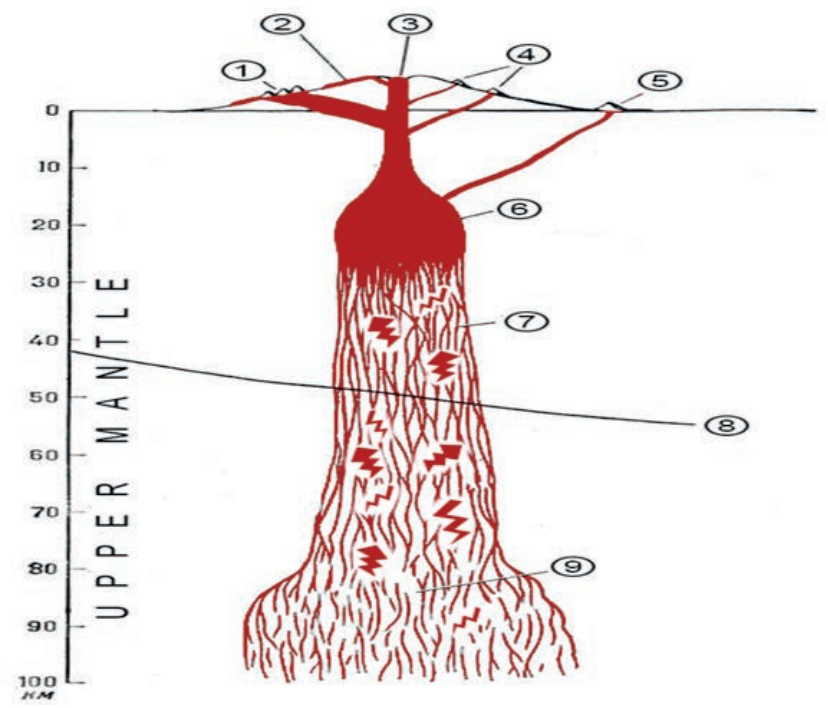

Рисунок 5 Строение вулканов. https://geography-a.ru/menu-3-21/277-vulkan.html

Figure 5 The structure of volcanoes. https://geography-a.ru/menu-3-21/277-vulkan.html

делением по внутренним степеням свободы, вследствие чего в породах возникнут огромные тангенциальные напряжения и мощные деформации сдвига. Время развития таких деформаций чрезвычайно мало и составляет $10^{-7}$ с. В породах мантии и земной коры возникнут экстремально высокие концентрации всевозможных дислокаций и дробление кристаллических решёток. В последующие $10^{-12}-10^{-9}$ с. произойдёт разрыв химических связей, резкое увеличение давления, температуры и плотности с образованием возбужденных состояний молекул с последующей их диссоциацией и, возможно, ионизацией. Спустя $10^{-6}$ с. произойдёт "разгрузка" очага волны, однако вследствие необратимых процессов место гидравлического удара останется нагретым, что будет способствовать образованию в породном массиве последующих смещений, образованию новых разломов и трещин, их перекрытие, а следовательно, и повторение гидравлических ударов и роя сейсмических волн.

Мощность гидравлического удара будет зависеть от размеров разломов и может достигнуть больших величин.

Время и место будущих гидравлических ударов носит случайный характер, следовательно, краткосрочный прогноз подземных толчков принципиально невозможен.

Рой вулканических землетрясений однозначно указывает на начало движения магматических масс к земной поверхности и активизацию вулкана

Механизм образования роя землетрясений является убедительным доказательством ничтожности сил упругих деформаций в процессах землетрясений. 


\section{СПИСОК ЛИТЕРАТУРЫ}

1. Рейд, Х. Ф. Теория землетрясений упругая отдача. Кафедра геологии. Университет Калифорния, 6 (19), 1910 с. $413-444$.

2. Рой землетрясений [Электронный ресурс] /. - Электрон. текстовые дан. - Wikipedia, Режим доступа: https:// en.wikipedia.org/wiki/Earthquake_swarm

3. Бычков, С.В. Конденсированная плазма как генератор землетрясений // Вестник Научно-исследовательского центра безопасности в угольной промышленности. — 2019. — № 2-2019. — С. 87-94.

4. Гидравлический удар [Электронный ресурс] /. - Электрон. текстовые дан. - Wikipedia, Режим доступа: https:// en.wikipedia.org/wiki/Water_hammer

5. Батолит [Электронный ресурс] /. — Электрон. текстовые дан. — Wikipedia, Режим доступа: https://en.wikipedia. org/wiki/Batholith

6. Добрецов, Н.Л. Толбачик - геохимическое явление [Электронный ресурс] / Н.Л. Добрецов. - Электрон. журн. НАУКА из первых рук, Режим доступа: https://scfh.ru/papers/tolbachik-geokhimicheskiy-fenomen/

7. Горячая точка. [Электронный ресурс] /. - Электрон. текстовые дан. - Wikipedia, Режим доступа: https:// en.wikipedia.org/wiki/Hotspot_(geology)

8. Что такое величина Рихтера? [Электронный ресурс] /. - Электрон. текстовые дан. - Невада Сейсмологическая Лаборатория, Режим доступа: http://www.seismo.unr.edu/ftp/pub/louie/class/100/magnitude.htm

\section{REFERENCES}

9. Reid, H. F. (n.d.). The elastic-rebound theory of earthquakes. Department Geology. Univ. Calif., 6(19), 413-444.

10. Earthquake swarm - https://en.wikipedia.org/wiki/Earthquake_swarm

11. Bychkov, S.V. (2019). Condensed plasma as an earthquake generator? Bulletin of Research Center for Safety in Coal Industry, 2.2019, 87-94. [In Russian].

12. Water hammer. (2019). Retrieved from https://en.wikipedia.org/wiki/Water_hammer.

13. Batholith. (2019). Retrieved from https://en.wikipedia.org/wiki/Batholith.

14. Dobretsov N.L. (2018, July 29). Tolbachik - geokhimicheskiy fenomen Tolbachik - geochemical phenomenon[]. Retrieved from https://scfh.ru/papers/tolbachik-geokhimicheskiy-fenomen/.

15. Hotspot (geology). (2019). Retrieved from https://en.wikipedia.org/wiki/Hotspot_(geology).

16. What is Richter Magnitude? (n.d.). Retrieved from http://www.seismo.unr.edu/ftp/pub/louie/class/100/magnitude.html.

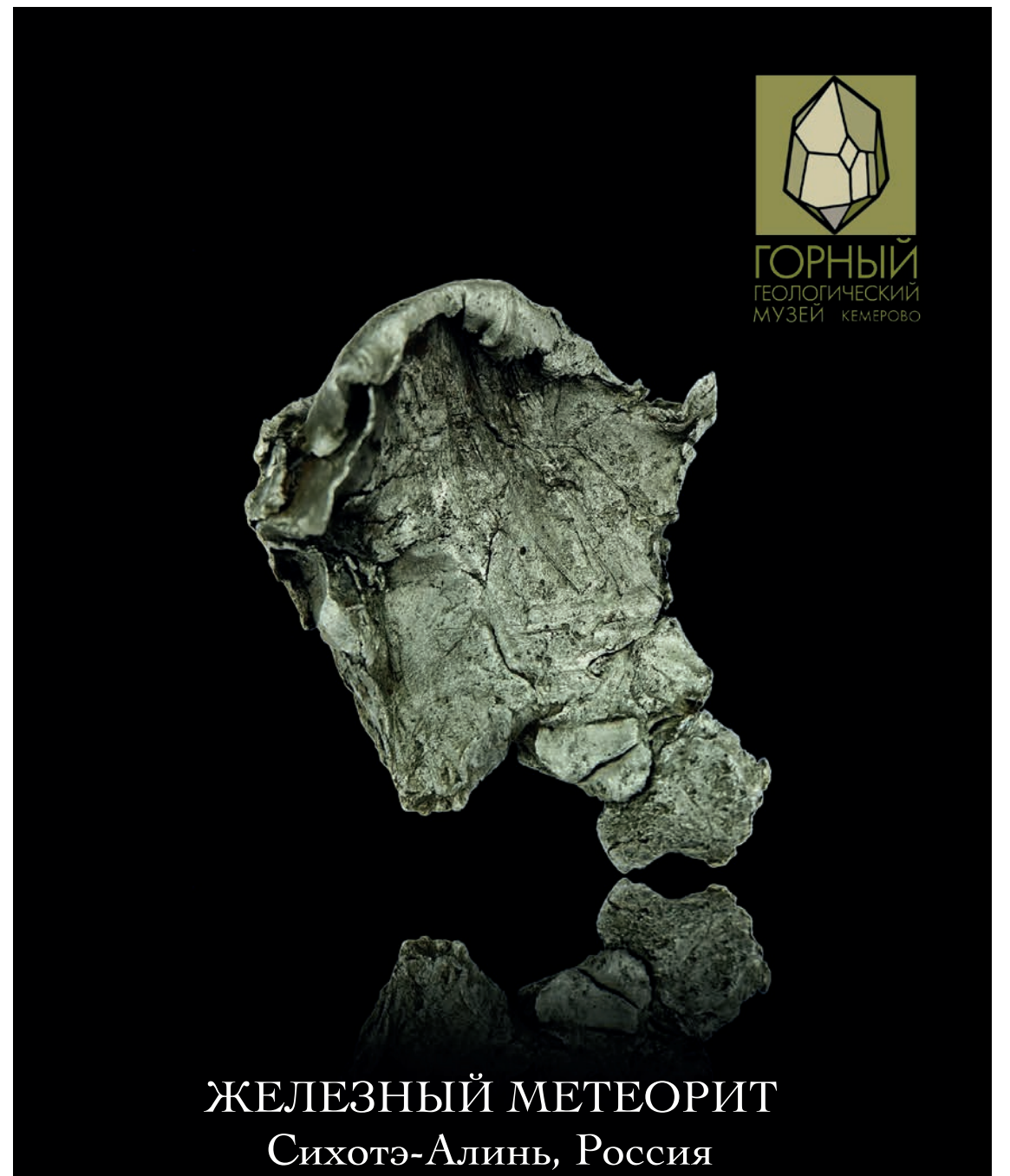




\title{
VI. МЕЖДУНАРОДНЫЙ ОПЫТ VI. PROBLEMS AND OPINIONS
}

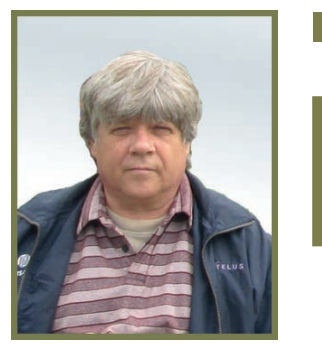

C.Б. Бычков// S.V. Bychkov sergueibychkov@gmail.com

горный инженер, Университет

Британской Колумбии, Ванкувер,

Канада

mining engineer University of British

Columbia, Vancouver, Canada

УДК 622.23:681.518.43

\author{
ТЕРМОЯДЕРНЫЙ СИНТЕЗ КАК ИСТОЧНИК СЕЙСМИЧЕСКИХ \\ ЯВЛЕНИЙ? \\ THERMONUCLEAR FUSION AS SEISMIC PHENOMENA \\ SOURCE?
}

Неразрешимый круг сложнейших вопросов, возникших при прогнозировании и объяснении причин землетрясений с позиции классической теории Упругой отдачи господина Рейда, поверг научный мир сейсмологов в глубокий пессимизм, ярко выраженный решением конгресса США прекратить фринансирование программ прогноза землетрясений, как пустую трату денег. Мир геофизики вплотную подошёл к признанию фракта, что за более чем столетнюю историю существования теория Рейда показала свою полную несостоятельность и примитивизм. Сообществу учёных стало очевидным, что одними законами классической механики и силами упругости невозможно объяснить причины катастрофических подвижек земной коры и пришло время для объединения усилий представителей различных научных дисциплин для решения проблем геофизики. Идейной и практической базой данной статьи послужили работы многочисленных групп фризиков и химиков [1], в которых приведены теоретические и экспериментальные результаты получения конденсированной плазмы в ведущих лабораториях мира, или так называемого тёплого плотного вещества (ТПВ). В статье изложена гипотеза, основанная на возможности природных сил не только образовывать конденсированную плазму в недрах нашей планеты, но и осуществлять посредством ТПВ реакции термоядерного синтеза - мюон - катализируемого плавления ( $\mu$ CF) [2, 3, 4] с возможностью перехода процесса в ядерные реакции "под урановым одеялом" и процесс формирования катастрофического землетрясения. Показаны модели глубокофокусных, мелкофоокусных и вулканических землетрясений.

The insoluble circle of the most complicated issues that arose when predicting and explaining the causes of earthquakes from the standpoint of the classic theory of Elastic recoil by Mr. Reid plunged the scientific world of seismologists into deep pessimism, clearly expressed by the decision of the U.S. Congress to stop funding earthquake prediction programs as a waste of money. The world of geophysics has come close to recognizing the fact that over more than a century of history, the Reid theory has shown its complete failure and primitivism. It became obvious to the scientific community that it is impossible to explain the causes of the catastrophic movements of the earth's crust by the laws of classical mechanics and elastic forces, and the time has come to join the efforts of various scientific discipline representatives to solve the problems of geophysics. The ideological and practical basis of this article was the work of numerous groups of physicists and chemists [1], which give theoretical and experimental results on obtaining condensed plasma, or the so-called warm dense substance (WDS) in the world's leading laboratories. The hypothesis based on the possibility of natural forces not only to form a condensed plasma in the bowels of our planet, but also with WDS to carry out thermonuclear fusion - muon - catalyzed fusion $(\mu \mathrm{CF}$ ) reactions $[2,3,4]$ with the possibility of transition of the process to nuclear reactions, "under the uranium blanket" and in the process of a catastrophic earthquake formation is presented in the article. Shown are models of deep focus, shallow focus and volcanic earthquakes.

КЛючевЫе слова: ТЕРМОЯДЕРНЫЙ СИНТЕЗ, ПЛАЗМА, ЗЕМЛЕТРЯСЕНИЕ, МАГМА, ГИДРАВЛИЧЕСКИЙ УДАР, МЮОН - КАТАЛИЗИРУЕМОЕ ПЛАВЛЕНИЕ, МЕЗОАТОМ, “УРАНОВОЕ ОДЕЯЛО”. 
Key words: THERMONUCLEAR FUSION, PLASMA, EARTHQUAKE, MAGMA, WATER HAMMER, MUON CATALYZED MELTING, MESOATOM, "URANIUM BLANKET".

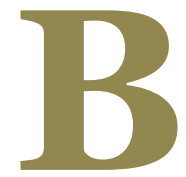

водная часть.

Теория землетрясений господина Рейда, разработанная более 100 лет назад (1910г.) преподносит процесс землетрясения как примитивную силу упругой деформации, действующую между тектоническими плитами и блоками, зажатыми в тиски объёмного давления окружающих пород. При этом абсолютно игнорируются законы термодинамики, а вместе с этим не учитываются экстремальные условия, в которых пребывают недра земли на глубине сотен километров. Это и температура в несколько тысяч градусов, высокое давление в десятки и сотни тысяч атмосфер, а также специфические фризико-химические состояния расплавленных, полурасплавленных и просто раскалённых плит и блоков, пропитанных различными газами, фрлюидами и магматическими расплавами. Не учитывается многообразие элементов и минералов, их молекулярный состав, энергия атомных связей, электромагнитные свойства и химические реакции пород образующих нашу планету. Теория Упругой отдачи также не учитывает, что в результате различных фазовых переходов и резкого изменения давления от сотен тысяч атмосфер и до нуля породы в любой момент могут изменить свои физико-химические свойства: мгновенно разрушиться, расплавиться, затвердеть, расшириться, сжаться, изменить молекулярную структуру (графит-алмаз) и т.д. А связывать сейсмологию и ядерные и термоядерные реакции, по мнению геофизиков, вообще легкомысленно, ибо в мире наук о Земле принято считать, что природные реакции термоядерного синтеза протекают в экстремальных условиях, не существующих на нашей планете. Утверждается, что эти условия присущи Солнцу, звёздам, недрам тяжёлых планет типа Юпитера и др., где значения высоких температур и давления могут заставить атомы водорода преодолевать взаимное кулоновское отталкивание и слиться в молекулы гелия с выделением энергии термоядерной реакции. Так было, пока в марте 1989 года химики Мартин Флейшман и Стенли Понс буквально взорвали информационный научный мир! Они сообщили об успешном осуществлении ими реакции термоядерного синтеза при комнатной температуре [5]. Эта новость не только восхитила весь мир, но и вдохновила учёных с энтузиазмом приступить к разработке идеи термоядерной реакции при низких температурах и давлениях $[6,7,8$,
9, 10, 11, 12, 13]. Открытые реакции назвали холодным термоядерным синтезом, или ХЯС. Эти реакции предполагают возможность прохождения ядерной реакции синтеза элементарных частиц в атомно-молекулярных системах без значительного нагрева рабочего вещества. Перед человечеством открывалась прекрасная перспектива получать энергию, минуя процесс сложной классической термоядерной реакции, для протекания которой необходимо сблизить ядра атомов, затратив энергию 0,1 МэВ, что эквивалентно температуре 11 миллионов градусов. Огромным бонусом для человечества при решении реакций ХЯС добавлялся вопрос значительного понижения уровня радиационного загрязнения, о серьёзности которого наглядно показала Чернобыльская авария. Прошли годы, к сожалению, множество сообщений и обширные базы данных об удачном осуществлении низкоэнергетических ядерных реакций ХЯС впоследствии оказывались результатом некорректно поставленных экспериментов или являлись результатом других фризико-химических эфрфектов, не связанных с термоядерным синтезом. В настоящее время большинство учёных относятся к заявлениям о холодном ядерном синтезе со скептицизмом [14, 15, 16, 17, 18, 19, 20, 21], однако эта область науки до сих пор активно изучается. К примеру, буквально на днях компания Google анонсировала многомиллионный грант на реанимацию этого проекта. Работая над нашей гипотезой, мы опирались на теоретические, экспериментальные и практические труды, накопленные человечеством по этой теме, но фундаментом этой статьи послужили работы [22, 23], в которых показана возможность получения ТПВ в недрах нашей планеты. Рассматривая возможную связь причин землетрясений с реакциями термоядерного синтеза, мы исходили из особенностей геологического строения нашей планеты, условий образования и взрыва ТПВ в недрах земли и способности плазмы в зоне её разлёта образовать достаточное количество мюонов для старта процесса мюон - катализируемого плавления ( $\mathrm{CCF})$. Мюон - катализируемое плавление - это процесс, позволяющий термоядерному синтезу происходить при температурах значительно ниже, чем температуры, требуемые для классической реакции термоядерного синтеза. Это один из хорошо известных современной науке способ реализации реакций синтеза ядер. Несмотря на то что этот процесс проходит при более низких 
параметрах температур и давлений чем классическая реакция, вероятность старта процесса остаётся довольно высокой. Основанием для такого рода утверждения служат условия прохождения реакций термоядерного синтеза, который, как нам известно, возможен при одновременном выполнении двух условий: скорость соударения ядер соответствует температуре плазмы:

$$
\begin{aligned}
& T>10^{8} \mathrm{~K} \text { (для реакции D-T). } \\
& \text { И соблюдение критерия Лоусона: } \\
& n T>10^{14} \mathrm{CM}^{-3} \cdot \mathrm{c} \text { (для реакции D-T) }
\end{aligned}
$$

где: $n$ - плотность высокотемпературной плазмы, т - время удержания плазмы в системе.

Исходя из того, что плотность ТПВ во много раз больше плотности идеальной плазмы, то по сравнению с условиями классического синтеза необходимое время удержания плазмы для начала реакции будет ничтожным, а замена электрона мюоном понизит необходимую скорость соударения ядер при эквивалентной энергии, а значит и температуру реакции. Описывая процесс получения в недрах земли конденсированной плазмы, мы исходили из того, что на глубинах десятков и сотен километров породы земной коры находятся под прессингом созданных природой экстремальных условий, которые вполне подходят для образования ТПВ. В этих условиях не хватает только мощной ударной волны, способной образовать плазму, которая обеспечит резкий скачок давления и температуры и достаточное для старта реакции термоядерного синтеза количество тяжёлых по сравнению с электронами мюонов. Реальность получения ТПВ за счёт энергии ударной волны экспериментально доказана во многих лабораториях мира. Образование в недрах земли высокоэнергетической ударной волны может быть вызвано различными причинами, связанными с фазовыми переходами, резким изменением физико-химических условий состояния тектонических блоков и плит от внезапного изменения горного давления с десятков тысяч атмосфер и до нуля, резкого изменения температур и другими причинами. К примеру, в отмеченной выше работе [22] рассмотрена ситуация, при которой в мантии земли происходит изученный ещё в 19 веке банальный гидравлический удар магмы, способный достичь уровня выделения энергии в несколько Тераватт, что вполне достаточно, чтобы образовать конденсированную плазму. Помимо реальных значений уровня давлений и температур, на глубинах сотен километров важными факторами возможного прохождения реакций синтеза является наличие в породах земной коры топливной базы в виде пригодных для термоядерных реакций природных элементов и их изотопов и природных катализаторов в виде высокогидрированных металлов и пород земной коры и мантии. Мы считаем, что при стечении вышеизложенных факторов и условий в недрах планеты вполне возможна реакция термоядерного синтеза, способная вызвать землетрясение.

Теоретическая часть.

Предложенная нами гипотеза работает по следующей схеме: образование по различным причинам ударной волны в недрах земли (в нашем случае - гидравлический удар магмы в недрах земли) $\rightarrow$ образование ТПВ $\rightarrow$ разлёт плазмы $\rightarrow$ образование мюонов $\rightarrow$ реакция термоядерного синтеза/мюон - катализируемого плавления $\rightarrow$ сейсмический импульс. Вкратце рассмотрим каждый этап процесса.

Явление гидравлического удара.

Гидравлический удар - это скачок давления в какой-либо системе, заполненной жидкостью, вызванный быстрым изменением скорости потока. Свойства жидкостей под высоким давлением и явление гидроудара детально изучены современной наукой [24, 25, 26], и нам остаётся только обратить внимание на специфические моменты этого явления глубоко под землёй. Гидравлический удар проявляется только в жёстких трубопроводах, что вполне соответствует условиям движения магмы по каналам породного массива. В результате внезапного перекрытия канала движения магмы сместившимся блоком пород поток магмы останавливается, и как по сценарию классического гидроудара его кинетическая энергия превращается в потенциальную энергию упругого сжатия магмы, а также потенциальную энергию упругого растяжения пород, образующих этот канал. Всё это приводит к тому, что давление в месте остановки магмы стремительно возрастёт тем больше, чем выше была скорость магмы и чем меньше её сжимаемость, а также чем выше жёсткость окружающих пород. Это повышение давления и является гидравлическим ударом внезапно остановленной магмы и первым этапом реакции термоядерного синтеза. В соответствии с расчетной формулой гидравлического удара, полученного российским ученым Жуковским еще в далёком 1898 году, энергия гидравлического удара будет зависеть от минерального состава магмы, плотности, состава окружающих пород, параметров движения магмы и её объема.

$$
\Delta P=\rho \cdot \Delta v \cdot C, \Pi a
$$

где $\Delta P$ - скачок давления; $\rho$ - плотность жидкости; $\Delta v$ - изменение скорости жидкости; $C$ - скорость распространения ударной волны в конкретной 
жидкой среде.

Энергия ударной волны - гидроудар магмы. Кинематика процесса.

Как мы отметили выше, ударная волна в недрах земли может возникнуть по нескольким причинам, одной из которых может быть гидравлический удар магмы. Гидроудар при изначальном огромном давлении и высоком температурном фоне на глубине несколько сотен километров, где вещества уже находятся и приобретают экстремальные и экзотические свойства и претерпевают необычные магматические и метаморфические трансформации пород (графрит - алмаз), ставит окружающие породы мантии в крайне неравновесные условия. Энергия ударной волны гидроудара вызовет мгновенный разогрев и так уже довольно горячего вещества мантии в районе события на сотни и тысячи градусов, а следовательно, мгновенное увеличение объёма окружающих пород. Мгновенное повышение давления возможно на тысячи атмосфер. Плюс, к таким резким скачкам давления будут соответствовать гигантские ускорения и торможения частичек вещества при прохождении через них возникшего фронта ударной волны. Для расчёта энергии гидравлического удара магмы необходимо знать её параметры, которые современная наука не в силах нам предоставить, но мы можем опытным путём установить их минимальные параметры. Известно, что алмазы образуются в магме. Для производства искусственных алмазов используется несколько технологий, из которых опытным путём установлено, что минимальная температура образования алмаза составляет от $1400^{\circ} \mathrm{C}$, а давление выше 50 тысяч атмосфер. То есть мы на 100\% можем утверждать, что гидроудар происходит в среде с этими минимальными параметрами, которые в действительности могут быть значительно выше. Второй важный, но неизвестный нам параметр, который присутствует в формуле Жуковского, - скорость потока магмы. Достоверно известно, что базальтовая лава при излиянии из кратера вулкана имеет скорость около 2.0 м/с., но её истинное значение на глубине 720 км предсказать невозможно. Возможно 2.0 м/с, а возможно и 10.0 м/с. и выше. Не зная точной цифры мы вынуждены принять минимально известную нам скорость $=2.0$ м/с. При абсолютно жестких стенках трубопровода скорость распространения ударной волны $C_{v}$ равна скорости распространения звука в магме $C_{v}=5760 \mathrm{~m} / \mathrm{c}$. Будем считать магму несжимаемой со средней

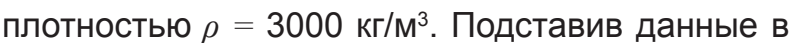
формулу Жуковского, мы получим мгновенный скачок давления:

$$
\Delta P=\rho \cdot \Delta v \cdot c=3000 \cdot 2.0 \cdot 5760=35 \text { МПа, (2) }
$$

где $\rho$ - удельная плотность базальтовой магмы

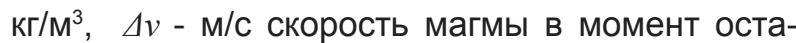
новки, $C_{v}$ равна скорости распространения звука в магме.

Рассчитаем энергию потока магмы:

$$
E_{\mathrm{k}}=\frac{m v^{2}}{2}
$$

где, $m$ - масса потока магмы $=V \cdot g$ - объём потока магмы, $v$ - скорость потока магмы.

При определении массы потока магмы мы должны определиться с её объёмом. При определении параметров будем исходить из опыта разработок кимберлитовых трубок, диаметр жерл которых нередко составляет 1000 и более метров. Примем диаметр канала $D=500$ м и длину канала потока магмы $L=500$ метров.

$$
\begin{gathered}
m=3.14 \cdot 2502 \mathrm{M}^{2} \cdot 500 \mathrm{M} \cdot 3000 \mathrm{\kappa} 2 / \mathrm{m}^{3}= \\
=294524310000 \mathrm{\kappa} 2 .(3)
\end{gathered}
$$$$
E_{k}=294524310000 \cdot 2^{2} / 2=589048620000 \text { Дж. }
$$

Время гидроудара составит:

$$
T=L / D=500 \mathrm{M} . / 5760 \mathrm{M} / \mathrm{c}=\underline{0.087 \mathrm{ce \kappa}} .
$$

Мощность

$$
W=E_{k} / T=589048620000 / 0.087=
$$$$
=6770673793103.5 \mathrm{Bm}=6.77 \text { Тероватm }
$$

Тротиловый эквивалент 1 к2. ТHT = 4,184・106 Дж

Эквивалент

$T H T=E_{k} / 4,184 \cdot 10^{6}$ Дж $=589048620000 /$

$$
14184000=\underline{140786 \kappa 2 .}
$$

Известно, что скорость прохождения фронта ударной волны в породах подземного массива составляет примерно от 3 до 6 км/с. В результате такого скоростного воздействия в породах земной коры возникает неравновесное состояние вещества и скачком увеличивается кинетическая энергия движения молекул, которая затем распределяется по внутренним степеням свободы. Следом за этим в породах возникнут огромные тангенциальные напряжения, которые вызовут мощные деформации сдвига. Время развития таких деформаций чрезвычайно мало и составляет $10^{-7}$ с. В породах мантии и земной коры создаются экстремально высокие концентрации всевозможных дислокаций и дробление кристаллических решёток. В последующие 1012 - 10-9 с. происходит разрыв химических связей, резкое увеличение давления, температуры и плотности с образованием возбужденных состояний молекул с последующей их диссоциацией и ионизацией. Финалом этого процесса будет рождение конденсированной плазмы. Спустя $10^{-6}$ с происходит "разгрузка" места удара волны, однако вследствие необратимых процессов ме- 
сто гидравлического удара остается нагретым, что способствует образованию в породном массиве последующих афтершоков.

Тёплое плотное вещество.

Существование ТПВ возможно при больших давлениях и температурах инициированных фазовыми переходами, связанными с ударными нагрузками, когда Кулоновские силы сопоставимы с силами теплового движения, то есть горячие недра коры и мантии являются идеальным местом для рождения конденсированной плазмы. ТПВ получено в лабораториях российского Сарова и в американском Лос-Аламосе и ещё, по крайней мере, в 15 лабораториях мира. Один из наиболее эффективных способов получения ТПВ заключается в использовании ударной волны мощностью на уровне Тераватт [11]. Согласно нашим расчётам этот же способ получения ТПВ эффективно использует природа в виде гидроудара магмы в мантии Земли, который служит источником энергии для скачкообразного фазового перехода пород недр в области гидравлического удара в конденсированную плазму, которая по своим параметрам находится между твёрдым телом и идеальной плазмой. ТПВ может образовываться из земных пород и элементов - от водорода до металлов. Давая определение ТПВ, фризики говорят: «Это состояние материи, достаточно плотное, чтобы не быть плазмой, и слишком горячее, чтобы описываться методами физики конденсированного состояния». ТПВ намного плотнее, чем плазма - от 0,01 до 100

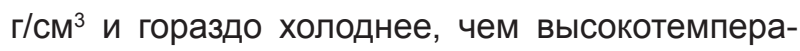
турная плазма. В некоторых случаях оно может иметь удельный вес в два раза больше, чем твёрдое вещество, из которого оно получено. Но и твёрдым телом его тоже назвать нельзя: атомы вещества имеют слишком большие скорости. Полученные цифры в приведённом выше расчёте кинетических параметров гидроудара показывают о реальной возможности получения ТПВ в недрах земли. Необходимо заметить, что мы вели расчёт по минимальным значениям, а реальные цифры могут оказаться на несколько порядков выше. Согласно The Nevada Seismological Laboratory [27] полученные нами параметры способны вызвать сейсмический удар магнитудой М 3.5-4.0 (!), что соответствует взрыву тактического ядерного заряда. Результатом этого процесса, по аналогии лабораторных экспериментов в Лос-Аламосе и других лабораториях мира, станет образование ТПВ. Далее произойдёт мгновенное увеличение его объёма и неконтролируемый разлёт плазмы.

Разлёт плазмы.
Главным препятствием на пути получения управляемой термоядерной реакции является удержание плазмы от процесса её разлёта. Существуют два способа удержания плазмы: магнитное и инерционное. В первом случае используют мощное магнитное поле, а во втором топливный элемент реакции подвергается одновременному “удару" с нескольких направлений мощными лазерными излучениями или пучками заряженных частиц. В условиях недр нашей планеты у природы нет инструментов удержания плазмы. Сам по себе разлёт плазмы представляет собой взрыв “оплазменных пород" из-за резкого расширения и увеличения их объёма и ведёт к образованию мюонов, которые служат катализатором реакции термоядерного синтеза. Здесь необходимо отметить, что при всём разнообразии предлагаемых к реализации способов осуществления низкотемпературных реакций термоядерного синтеза их роднит общая идея: нагреть ядра дейтерий-тритиевой плазмы до средней температуры 10 кэВ с тем, чтобы небольшая их часть могла пройти сквозь потенциальный барьер кулоновского отталкивания ядер и вступить в реакцию синтеза гелия. Эта идея по существу ничем не отличается от способов увеличения скорости химических реакций: предварительно нагреть реакционные компоненты либо применить катализаторы. Как доказано современными исследованиями, в качестве катализатора для реакций термоядерного синтеза можно использовать отрицательно заряженный мюон. Обычно катализаторы стоят дорого, и рентабельность их использования зависит от затрат на их производство, а также относительной стоимости всей каталитической установки. На современном этапе развития ядерной промышленности получение мюонов крайне затруднительно и экономически нерентабельно, и поэтому реакция термоядерного синтеза/мюон - катализируемого плавления не рассматриваются учёными как перспективный источник получения энергии. Но для природы вопроса рентабельности не существует.

Образование мюонов.

Мюоны были впервые обнаружены в космических лучах в далёком 1936 году. Они образуют $80 \%$ всех частиц космического излучения и имеют скорости близкие к скорости света. На современных ускорителях получают пучки мюонов с интенсивностью $10^{5} \approx 10^{6}$ частиц в секунду. Так как масса мюона много больше массы электрона, они обладают высокой проникающей способностью, в результате чего мюоны космических лучей не только легко проникают через 
атмоссреру Земли, но и углубляются на довольно значительные расстояния в недра земли. В подземных экспериментах мюоны космических лучей с энергией $10^{12} \approx 10^{13}$ эВ регистрировались на глубине нескольких км. Образование мюонов происходит при распаде так называемого т - мезона, который распадается на три элементарные частицы: два разнополярных мюона $\mu^{-}, \mu^{+}$и мюонное нейтрино. Кроме этого, мюоны образуются в результате процесса столкновения высокоскоростных электронов и позитронов, который в нашем случае происходит при разлёте ТПВ в недрах земли по схеме: $e_{-}+e+\rightarrow \mu^{-}+\mu^{+}$. При этом отрицательный $\mu^{-}$захватывается ближайшим атомом, образуя при этом процессе мюонные атомы или мезоатомы в результате замены электронов на отрицательные мюоны. Нам известно, что радиус Бора обратно пропорционален массе частицы, движущейся вокруг атомного ядра, значит, в силу того, что масса мюона $m_{\mu}=206,769 m_{e}$ более чем в двести раз превосходит массу электрона, то размер вновь образованной орбитали атома будет во столько же раз меньше аналогичной электронной. В результате размеры мюоновой орбитали сравнимы или не более чем на порядок превосходят размеры ядра (!). Также малые размеры атомов позволяют атомным ядрам сильно сблизиться и слиться, что используется для осуществления идеи термоядерного синтеза/мюон - катализируемого плавления.

Реакция термоядерного синтеза/мюон катализируемого плавления.

Основная идея $\mu$ - катализа ядерных реакций состоит в следующем. Попадая в термоядерное топливо, к примеру, в водородную среду, свободные мюоны “выгоняют" и заменяют собой в атомах электроны и образуют атом протон-мюона $(H-\mu)$, атом дейтрон-мюона $(D-\mu)$ и атом тритон-мюона $(T-\mu)$, которые, сталкиваясь затем с молекулами $H_{2}, D_{2}, T_{2}, H D, H T, D T$, образуют мезомолекулы $H H-\mu, H D-\mu, H T-\mu, D D-\mu$, $D T-\mu$ и TT- $\mu$. Обратите внимание: в мезомолекулах ядра удалены на расстояние примерно в две мезоатомных единицы $\sim 2 a_{\mu}=2 h^{2} / m_{\mu} e^{2} \sim 5 \cdot 10^{-11} \mathrm{~cm}$, причем такое сближение происходит при незначительных с точки зрения классической реакции термоядерного синтеза температурах. На такое же расстояние в классической реакции ядра изотопов водорода сближаются только при кинетической энергии 3 кэВ, что соответствует 30 миллионам градусов!!! После образования ме-

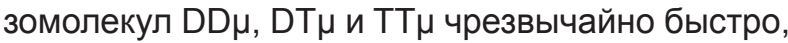
за время $\tau$ порядка $10^{-9}-10^{-12}$ с, происходит слияние их ядер. Классические реакции:

$$
D+D \rightarrow p+T+4,032 \text { МэB }
$$

$$
\begin{aligned}
& D+D \rightarrow n+{ }^{3} H+3,268 \text { Mэ } B \\
& D+T \rightarrow n+{ }^{4} H+17,589 \text { МэB } \\
& T+T \rightarrow 2 n+{ }^{4} H+11,332 \text { MэB } \\
& P+D \rightarrow{ }^{3} H+\gamma+5,4 M \ni B \\
& P+T \rightarrow{ }^{4} H+\gamma+19,814 M \ni B
\end{aligned}
$$

При этих реакциях происходит высвобождение мюона, и цепочка описанных превращений повторяется до момента распада мюона. Но число реакций синтеза инициируемых одним мюоном ограничено величиной коэффрициента прилипания мюона к гелию равного 0,3-1 \%. И последнее, нам следует отметить важное замечание: реакции синтеза между ядрами лёгких элементов могут осуществляться от водорода, лития, бериллия и вплоть до железа, что существенно расширяет топливную базу термоядерных реакций. Как мы уже отмечали выше, в настоящее время эти реакции не могут быть использованы в управляемом термоядерном синтезе, так как они невыгодны из-за высоких энергетических затрат на получение мюонов, но, как мы раньше отметили, природе нет никакого дела до получения экономической выгоды процесса, для природы важен другой показатель равновесие систем.

Сейсмический импульс.

Выделившаяся энергия термоядерного синтеза запустит в подземном массиве хорошо изученный процесс упругого удара, который в виде механического импульса распространится в массиве со скоростью сейсмической волны. На фронте волны будет действовать ньютоновская сила изменения импульса, давление которой будет пропорционально производной плотности импульса по времени и которая при выходе на поверхность вызовет сейсмические разрушения. Количество движения будет распространяться в среде в виде продольной волны $P$, а момент количества движения - в виде поперечной волны $S$.

Модель образования землетрясения энергией термоядерной реакции.

Исходя из фризико-химических условий существования материи в недрах Земли, возможности образования там ТПВ и вспышки термоядерной реакции, представляем вам модель образования глубокофокусного землетрясения. Обращаем ваше внимание на то, что на глубинах 300-700 км. породы недр существуют в пластических и полужидких состояниях, для которых теория Упругой отдачи господина Рейда никаким образом не сможет найти объяснение образованию в породах сейсмических толчков с позиции сил упругости. Гидроудар магмы при изначальном огромном давлении и высоком тем- 
пературном фоне на глубине несколько сотен километров, где вещества уже находятся и приобретают экстремальные и экзотические свойства и претерпевают необычные магматические и метаморфические трансформации пород (графрит - алмаз), ставит окружающие породы мантии в крайне неравновесные условия. Энергия ударной волны гидроудара вызовет мгновенный разогрев и так уже довольно горячего вещества мантии в районе события на десятки тысяч градусов, что вызовет мгновенное увеличение объёма окружающих пород и повышение давления на сотни и тысячи атмосфер. Таким резким скачкам давления будут соответствовать гигантские ускорения и торможения частичек вещества при прохождении через них возникшего фронта ударной волны. Результатом этого процесса, по аналогии лабораторных экспериментов в ЛосАламосе и других лабораториях мира, станет появление ТПВ. Уровень давлений и температур ТПВ таков, что оно, мгновенно расширяясь, взорвётся. Огромная скорость приложения нагрузки создаст чудовищные напряжения в материале и тем самым включит новые механизмы деформации с образованием обвального разрушения массива пород по типу цепной реакции. В момент разлёта ТПВ произойдёт образование ионизированных частиц: ионов, мюонов, электронов и нейтральных частиц и их инжекция в зону разлёта ТПВ. В процессе инжекции произойдёт захват водородными ядрами мюонов, образование мезомолекул с последующим слиянием ядер и вспышка термоядерной реакции мюонного катализа, которая быстро потухнет по причине прилипания мюонов к синтезированным ядрам. По этой причине, как нам кажется, катастрофические землетрясения случаются довольно редко, раз в один-два года, так как суммированной энергии гидравлического удара и энергии скоротечного термоядерного синтеза будет достаточно только для землетрясений малых и средних магнитуд. Для образования катастрофических землетрясений потребуется колоссальная энергия, измеряемая миллиардами тонн тротилового эквивалента, которую природа вполне может получить, “укрыв область термоядерной реакции урановым одеялом”. Дело в том, что если в области разлёта ТПВ находятся элементы урановой группы, то при термоядерной реакции

$$
D+T \rightarrow n+{ }^{4} H+17,589 \text { МэВ }
$$

образуется высокоэнергетический 14,1 МэВ нейтрон, который, попадая в урановое топливо, производит одно деление ядра уранового элемента с выделением энергии в одиннадцать

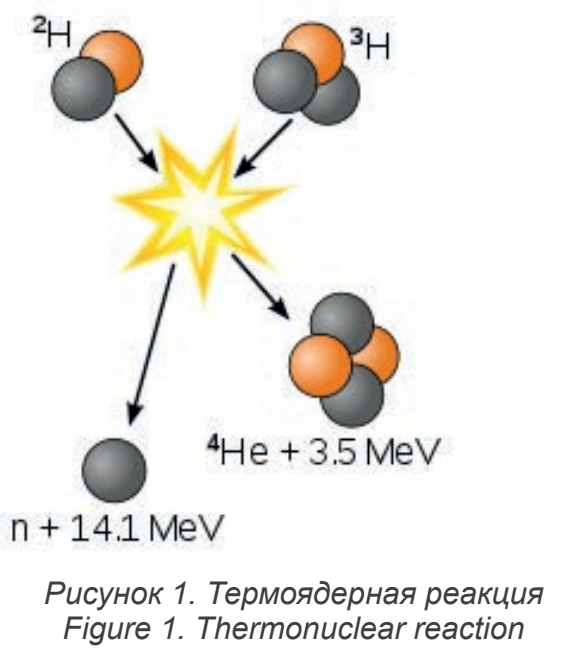

раз больше, чем при слиянии одного ядра в термоядерной реакции. По этому принципу работает водородная бомба. То есть, если обложить поверхность термоядерной бомбы «одеялом» допустим из урана-238, то под действием быстрого нейтрона из реакции синтеза ядро урана расщепляется по принципу цепной ядерной реакции:

- одна реакция термоядерного синтеза 17,6 МэВ плюс нейтрон;

- ядерная реакция деления "под урановым одеялом" 200 МэВ.

Таким образом, если в районе разлёта ТПВ окажутся элементы урановых веществ, что при их распространенности в земной коре вполне реально, то “урановое одеяло” позволит природе легко поднять магнитуду землетрясения до катастрофического уровня.

Мелкофокусные и вулканические землетрясения.

Мелкофокусные и вулканические землетрясения развиваются по идентичному принципу. Здесь нам могут возразить, что условия нахождения пород в очагах этих типов землетрясений не такие экстремальные, как на глубинах глубокофокусных толчков и, следовательно, возникающие в толще земли и в вулканических камерах гидроудары не смогут образовать достаточно большое количество мюонов для вспышки термоядерной реакции. Это так, но природа за счёт высокой проникающей способности мюонов, отмеченной нами выше, дала этим частицам отличных шанс поучаствовать в термоядерных реакциях на малых глубинах измеряемых десятком километров, куда они легко проникают в достаточно большом количестве. Например, телескоп GRAPES-3, расположенный в индийском городе Ути, для изучения атмосферы регистрирует около 2,5 миллионов мюонов в минуту. Пока вы читали последнюю фразу, через 
вас пролетело примерно 10 -15 тысяч мюонов! Значит, имея ударную волну, + достаточное количество мюонов, + температуру порядка 1400 градусов и + высокое давление магмы в каналах и вулканических камерах, природа способна начать термоядерную реакцию синтеза и вызвать подземные толчки на малых глубинах. Хорошо известное и таинственное явление вулканического дрожания не является ли следствием установившейся термоядерной реакции? В завершении статьи мы должны отметить, что мы сознательно, в целях не утяжелять материал, избегали детализации химических и ядерных процессов и не вдавались в квантовые процессы туннелирования высокоэнергетических, ионизированных частиц, возникающих при образовании конденсированной плазмы, способных помимо мюонов катализировать процесс термоядерной реакции.

Заключение.

Ударная волна - эффрективный способ получения конденсированной плазмы в недрах земли, способной привести к природной вспышке термоядерной реакции синтеза за счёт мюон - катализируемого плавления с возможным переходом процесса к ядерным реакциям “под урановым одеялом". Подтверждение нашей гипотезы послужит значительным шагом вперёд в объяснении сейсмической активности недр и определит новые подходы к изучению причин землетрясений, а также позволит ответить на вопросы, связанные с геологическим процессом формирования нашей планеты и физического образования разнообразия химических элементов и минералов. К великому сожалению, из вышеизложенного процесса образования землетрясений можно сделать неутешительный вывод для человечества: старт любого землетрясения является чистой случайностью, и, следовательно, говорить о возможности прогноза землетрясений не имеет смысла, как и тратить на это деньги. Можно пространственно рассуждать и делать прогнозы на периоды времени от десятков и до тысячи лет, но точное время и место будущего землетрясения предсказать невозможно. Для геофизиков, сомневающихся в нашем выводе, хотелось бы заметить, что многовековая и кровавая история землетрясений и развития жизни на земле доказала это на печальном опыте людей, пострадавших при катастрофических подвижках земной коры.

\section{СПИСОК ЛИТЕРАТУРЫ}

1. Ричард В.Л. Исследования плазмы и теплой плотной материи. —Электрон. текстовые дан. —Режим доступа: https://www-ssrl.slac.stanford.edu/lcls/talks/rlee_wdm_100400.pdf.

2. Фрэнк Ф. С. Гипотетические альтернативные источники энергии для событий «Второго мезона». Природа, 160 (4068). С. 525-527

3. Альварес Л., Брэднер Х., мл., Ф.С., Кроуфорд Дж., Фальк-Вайрант П., Гуд М., Трипп Х. Катализ ядерных реакций мю-мезонами. Физический обзор. 105 (3), 1127. —1956.

4. Джексон, Дж. Д. Катализ ядерных реакций между изотопами водорода мю-мезонами. Физический обзор, 106 (2). -1957. С. 330-339.

5. Флейшман М., Понс С. Электрохимический индуцированный ядерный синтез дейтерия. //Журнал электроаналитической химии и межфазной электрохимии, 261 (2). С. 301-308.

6. Куксон, С. Ученые утверждают, что ядерный синтез производится в пробирке. //Файнэншл Таймс, 1. - 1989.

7. Бишоп Дж. Прорыв в фрьюжн может быть объявлен. //Уолл Стрит Дж. Б1. —1989.

8. Браун, М. В. Слияние в банке: утверждение химиков разжигает шум. //Нью-Йорк Таймс, 1. -1989.

9. Мискелли Г.М. и др. Анализ опубликованных калориметрических данных об электрохимическом синтезе дейтерия в палладии. Наука 246. С. 793-796. -1989.

10. Альбагли Д. и соавт. Измерение и анализ уровней нейтронного и гамма-излучения, других продуктов синтеза и мощности в электрохимических ячейках с катодами. Энергия синтеза 9. С. 133-148. - 1990.

11. Уильямс, Д. Э. и соавт. Верхние границы «холодного синтеза» в электролизерах. Природа 342. С. 375-384 -1989.

12. Мэддокс Дж. Прощай, холодный синтез. Природа 344. С. 365-366. -1990.

13. Автор Н. Г. Исследование холодного синтеза. -1989.

14. Маллинс Дж. Холодный синтез вернулся из мертвых. IEEE Спектр 41. С. 22-23. —2004

15. Риттер С.К. Холодный синтез умер 25 лет назад, но исследования продолжаются. Химреагент Eng. //Hoвости 94. С. 34-39. -2016.

16. Кривит, С. Б. и Марван. Дж. Новый взгляд на низкоэнергетические исследования ядерных реакций. Среда. Монит. 11, 1731-1746. -2009.

17. Сандерсон К. (2007). Холодный синтез вернулся в Американское химическое общество. Природа. [Электронный ресурс]. Режим доступа: news070326-12

18. Гудштейн, Д. Что случилось с холодным синтезом? Ответственность за исследования, 8 (1-2). С. 59-75. —2000

19. Кривит С. Б. Низкоэнергетические ядерные реакции: появление ядерной науки о конденсированных средах. Серия низкоэнергетических ядерных реакций ACS Symposium Series, 3-16. -2008.

20. Мохтади Р. и Оримо С.-И. Возрождение гидридов как энергетических материалов. Материалы Обзоров Природы, 2 (3). -2016.

21. Мохтади Р. и Оримо, С.-И. Возрождение гидридов как энергетических материалов. Материалы Обзоров Природы, 2 (3). -2016. 
22. Бычков С.В. Конденсированная плазма как генератор землетрясений? //Вестник Научно-исследовательского центра по безопасности в угольной промышленности, 2.2019, С. 87-94. -2019.

23. Фортов В. Интенсивные ударные волны и экстремальные состояния вещества "Физ. Усп." - 2007. —Электрон. текстовые дан. -Режим доступа: http://www.mathnet.ru/php/archive.phtml?wshow=paper\&jrnid=ufn\&paperid=451 \&option_lang=eng.

24. Гидравлический удар. -2019. —Электрон. текстовые дан. — Wikipedia, Режим доступа: https://en.wikipedia.org/ wiki/Water hammer

25. Торли, А. Р. Д. Переходные процессы жидкости в трубопроводных системах: руководство по контролю и подавлению переходных процессов жидкости в жидкостях в закрытых каналах. Нью-Йорк: ASME Пресс. -2004.

26. Тисселинг, Аррис С. и Андерсон, Александр. Предшественник в анализе гидравлического удара - новое открытие Йоханнеса фон Криса. Материалы 9-й Международной конференции по скачкам давления, Честер, Великобритания. С.739-751, заархивированы с оригинала 2016-03-04. -2004.

27. Что такое величина Рихтера? -Электрон. текстовые дан. -Режим доступа: http://www.seismo.unr.edu/ftp/pub/ louie/class/100/magnitude.html.

\section{REFERENCES}

1. Richard, W.L. (n.d.). Plasm a and Warm Dense Matter Studies. Retrieved from https://www-ssrl.slac.stanford.edu/lcls/ talks/rlee_wdm_100400.pdf.

2. Frank, F. C. (1974). Hypothetical Alternative Energy Sources for the 'Second Meson' Events. Nature, 160(4068), 525-527. doi: 10.1038/160525a0

3. Alvarez, L., Bradner, H., Jr, F. C., Crawford, J., Falk-Vairant, P., Good, M., ... Tripp, H. (1956). The Catalysis of Nuclear Reactions by mu Mesons. Physical Review, 105(3), 1127. doi: 10.2172/878129

4. Jackson, J. D. (1957). Catalysis of Nuclear Reactions between Hydrogen Isotopes by 106(2), 330-339. doi: 10.1103/physrev.106.330

5. Fleischmann, M., \& Pons, S. (1989). Electrochemically induced nuclear fusion of deuterium. Journal of Electroanalytical Chemistry and Interfacial Electrochemistry, 261(2), 301-308. doi: 10.1016/0022-0728(89)80006-3

6. Cookson, C. (1989, 23 March). Scientists claim nuclear fusion produced in test tube. Financial Times, 1

7. Bishop, J. (1989, 23 March). Breakthrough in fusion may be announced. Wall Street J. B1

8. Browne, M. W. (1989, 28 March). Fusion in a jar: chemists' claim ignites an uproar. New York Times, 1

9. Miskelly, G. M. et al. (1989). Analysis of the published calorimetric evidence for electrochemical fusion of deuterium in palladium. Science $246,793-796$

10. Albagli, D. et al. (1990). Measurement and analysis of neutron and gamma-ray emission rates, other fusion products, and power in electrochemical cells having Pd cathodes. J. Fusion Energy 9, 133-148

11. Williams, D. E. et al. (1989). Upper bounds on 'cold fusion' in electrolytic cells. Nature 342, 375-384

12. Maddox, J. (1990). Farewell Cold fusion. Nature 344, 365-366

13. Author, N. G. (1989). Cold fusion research. doi: $10.2172 / 5144772$

14. Mullins, J. (2004). Cold fusion back from the dead. IEEE Spectrum 41, 22-23

15. Ritter, S. K. (2016). Cold fusion died 25 years ago, but the research lives on. Chem. Eng. News 94, 34-39

16. Krivit, S. B. \& Marwan. J. (2009). A new look at low-energy nuclear reaction research. J. Environ. Monit. 11, 1731-1746

17. Sanderson, K. (2007). Cold fusion is back at the American Chemical Society. Nature. doi: 10.1038/news070326-12

18. Goodstein, D. (2000). Whatever happened to cold fusion? Accountability in Research, 8(1-2), 59-75. doi: $10.1080 / 08989620008573966$

19. Krivit, S. B. (2008). Low Energy Nuclear Reactions: The Emergence of Condensed Matter Nuclear Science. LowEnergy Nuclear Reactions Sourcebook ACS Symposium Series, 3-16. doi: 10.1021/bk-2008-0998.ch001

20. Brumfiel, G. (2004). US review rekindles cold fusion debate. Nature. Retrieved from https://www.nature.com/ news/2004/041129/full/news041129-11.html.

21. Mohtadi, R., \& Orimo, S.-I. (2016). The renaissance of hydrides as energy materials. Nature Reviews Materials, 2(3). doi: 10.1038/natrevmats.2016.91.

22. Bychkov, S.V. (2019). Condensed plasma as an earthquake generator? Bulletin of Research Center for Safety in Coal Industry, 2.2019, 87-94. [In Russian].

23. Fortov V. (2007). Intense shock waves and extreme states of matter" Phys. Usp. Retrieved from http://www.mathnet. $\mathrm{ru} / \mathrm{php} /$ archive . phtml?wshow=paper\&jrnid=ufn\&paperid=451\&option lang=eng.

24. Water hammer. (2019). Retrieved from https://en.wikipedia.org/wiki/W̄Water_hammer

25. Thorley, A. R. D. (2004). Fluid transients in pipeline systems: a guide to the control and suppression of fluid transients in liquids in closed conduits. New York: ASME Press.

26. Tijsseling, Arris S.\&Anderson, Alexander (2004), A precursor in water hammer analysis - rediscovering Johannes von Kries. Proceedings of the 9th International Conference on Pressure Surges, Chester, UK, 739-751, archived from the original on 2016-03-04.

27. What is Richter Magnitude? (n.d.). Retrieved from http://www.seismo.unr.edu/ftp/pub/louie/class/100/magnitude.html. 


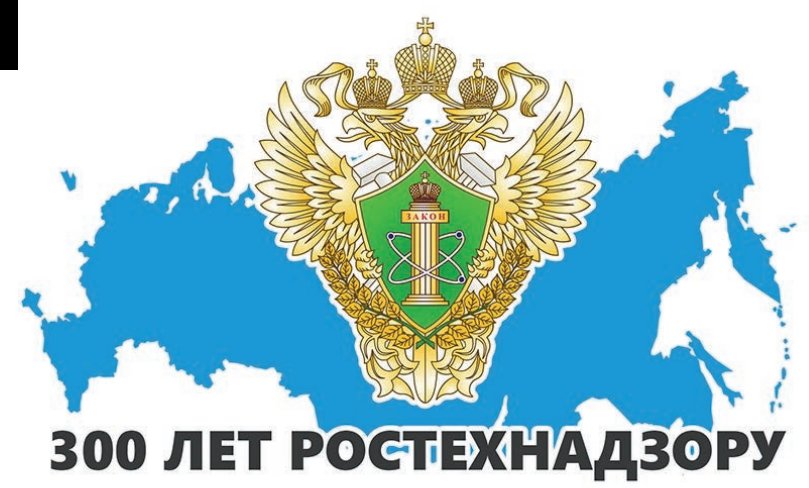

\section{Уважсаемые коллеги!}

От имени редакционной коллегии научно-технического журнала «Вестник научного ичентра по безопасности работ в угольной промышленности», а также от группь компаний ООО «ВостЭКО» и ООО «Горный-ЦОТ» сердечно поздравляем Федеральную службу по экологическому, технологическому и атомному надзору (Ростехнадзор) с 300-летним юбилеем на страже безопасности граждан.

Для Кузбасса, как и для других угледобывающих регионов, проблема промышленной и экологической безопасности является одной из самых актуальных. Эти приоритетные задачи ежедневно и ежечасно решаются высокими профессионалами Вашей службы благодаря богатейшему опыту, высокому чувству ответственности и глубокому пониманию вопросов безопасности наших граждан.

Желаем дальнейшего процветания вашей службе, успехов в решении сложных задач и воплощения всех намеченных планов! 


\section{ТРЕБОВАНИЯ К РАЗМЕЩЕНИЮ РЕКЛАМНЫХ МАТЕРИАЛОВ}

Научно-технический журнал «Вестник Научного центра по безопасности работ в угольной промышленности» приглашает научные институты, организации и промышленные предприятия разместить информацию о конференциях, выставках, разрабатываемой и выпускаемой продукции в области охраны труда, безопасности в чрезвычайных ситуациях, пожарной и промышленной безопасности в угольной промышленности, контроля природной среды, веществ, материалов и изделий, а также приборостроения.

\section{РАЗМЕРЫ РЕКЛАМНЫХ МОДУЛЕЙ:}

- размер для 1 полосы: 216*303 мм, включая по 3 мм на обрезку с каждой стороны внешнего периметра, на корешок допуск ставить не нужно.

- 1/2 полосы вертикальная: 103*303 мм,

- 1/2 полосы горизонтальная: 216*151 мм

- 1/3 полосы горизонтальная: 216*92 мм

- 1/4 полосы горизонтальная: $216^{*} 67$ мм

- 1/4 полосы вертикальная в верхнем или нижнем внешнем углу страницы: 103*151 мм

ТРЕБОВАНИЯ К РЕКЛАМНЫМ СТАТЬЯМ

1. Текст для статьи предоставляется тольков текстовом редакторе Word.

2. Объем статьи: не более 4500 печатных знаков с пробелами (без изображений). При использовании фотографий объем текста пропорционально уменьшается.

3. Требования к фотографиям: формат .eps или .tiff с разрешением $300 \mathrm{dpi}$.

4. Логотип-в форматах.cdr, .eps, приэтом шрифтыдолжныбыть переведены в кривые.

5. Текст рекламной статьи должен включать заголовок (подзаголовок), выходные данные заказчика: название, адрес, телефон, электронный адрес компании.

\section{ТРЕБОВАНИЯ К РЕКЛАМНЫМ МАКЕТАМ}

1. Размер электронного макета должен соответствовать размерам рекламного модуля.

2. Растровые фрайлы должны быть в форматах .tif, .psd, .eps с разрешением 300 dрі , векторные .ai, .eps u .cdr.

3. Оригинал-макетыпередаются в цветовой модели СМҮК без компрессии.

4. Верстка может быть в форматах Adobe illustrator, Corel Draw, Adobe Indesign (в этом случае должны предоставляться все связанные элементы, а также все используемые шрифты, обязательно макет должен так же прилагаться в pdf).

5. В макете, подготовленном в пакете Corel Draw не допускается наличие следующих эффектов: shadow, transparency, gradient fill, lens, texture fill и postscript fill. Все вышеперечисленные эффректы Corel Draw должны быть конвертированы в bitmap $300 \mathrm{dpi.}$

6. Черный цвет текста должен состоять только из черного канала - С:0, М:0, Y:0, К:100 или 100 Black в одноцветной шкале Grayscale.

7. Все текстовые элементы оригинал-макета должны быть переведены в кривые.

8. Текст и важные изображения (логотип и т. п.) не должны располагаться ближе 5 мм к обрезному краю.

Информация о расценках на размещение рекламы размещена на сайте www.ind-saf.ru. риалов.

Редакция журнала оставляет за собой право отбора поступивших рекламных мате- 


\section{ТРЕБОВАНИЯ, УСЛОВИЯ И ПОРЯДОК ПРЕДСТАВЛЕНИЯ РУКОПИСЕЙ В НТЖ «Вестник Научного центра по безопасности работ В угольной промышленности»}

\section{I. Порядок представления материалов в редакцию}

1. В журнал принимаются статьи, соответствующие его тематике - охрана труда, безопасность в чрезвычайных ситуациях, пожарная и промышленная безопасность в угольной промышленности, приборы и методы контроля природной среды, веществ, материалов и изделий.

2. Статья должна быть оригинальной, не представленной в других изданиях.

3. На основании положений части четвертой Гражданского кодекса Российской Федерации (раздел VII «Права на результаты интеллектуальной деятельности и средства индивидуализации») представляемые в журнал статьи должны сопровождаться лицензионным договором о передаче ООО «ВостЭКО» (издатель журнала) простой (неисключительной) лицензии. Договор заполняется на бланках по образцам лицензионных договоров с одним или коллективом авторов (при написании статьи несколькими авторами). Лицензионный договор является договором присоединения. Необходимо заполнить и подписать договор, отсканированный вариант отправить по e-mail: yarosh_mv@mail.ru, два первых экземпляра оформленного договора отправить в редакцию по почте: $6500 \overline{0}$, Кемерово, Сосновый бульвар, д. 1, ООО «ВостЭКО». Договор, подписанный автором/авторами и направленный по электронной почте, признается равнозначным документу на бумажном носителе, подписанному собственноручной подписью, порождающим права и обязанности сторон. Скачать бланки договора можно на сайте www.indsafe.ru.

\section{II. Форма представления рукописи}

1. Рукопись представляется отпечатанной в текстовом редакторе Word через 1,5 интервала на одной стороне стандартного листа белой бумаги формата А4 и в электронном виде (передается по электронной почте yarosh_mv@mail.ru или на магнитном носителе).

2. Все страницы рукописи, включая таблицы, список литературы, рисунки должны быть пронумерованы. Рекомендуемый объем статьи 5-7 страниц. Статья должна быть подписана всеми авторами.

3. Плата с аспирантов за публикацию рукописей не взимается.

Подготовка электронной версии материалов

1. Текст набирается шрифтом Times New Roman, размер шрифта 12, для заголовка 16, полуторный интервал, абзацный отступ 1,25 см, формат листа А4. Поля с левой стороны 3 см, сверху и снизу и справа 2 см;

2. Электронная версия должна быть идентична распечатанному тексту. В случае расхождения за основу берется печатный вариант.

\section{Структура статьи}

1. Индекс УДК.

2. Фотографрии всех авторов (форматы: TIF, Jpeg, Png, не сканированные, не ретушированные, не обрезанные, разрешение $300 \mathrm{dpi)}$.

3. Инициалы и фамилия автора (ов).

4. Место работы.

5. Название статьи.

6. Рефрерат. Реферат должен быть инфрормативным, отражать основное содержание статьи и результаты исследований, следовать логике описания результатов в статье, укладываться в объем от 100 до 250 слов. Возможно краткое повторение структуры статьи, включающей введение, цели и задачи, методы, результаты, заключение.

7. Ключевые слова.

8. Текст статьи с таблицами, иллюстрациями, формулами.

9. Список литературы (оформленный в соответствии с ГОСТ Р 7.0.5 - 2008 «Библиографическая ссылка. Общие требования и правила составления»). жать:

На отдельном листе или в конце статьи размещается «Список авторов», который должен содер-

- публикуемые сведения об авторах (название организации указывается в соответствии с учредительными документам));

- служебные или домашние адреса с указанием почтового индекса;

- адрес электронной почты (e-mail).

Обращаем ваше внимание, что представление оригинальной статьи к публикации в НТЖ означает согласие авторов на передачу права на воспроизведение, распространение и доведение произведения до всеобщего сведения любым способом. 


\section{СЛОВО РЕДАКТОРА // EDITORIAL}

5 Трубицына H. Trubitsyna N.

5 Трубицына H. Trubitsyna N.

\section{AKTУAЛЫНО // IMPORTANT}

6 С.Б. Романченко, В.В.Соболев, А.А. Трубицын Физико-химические преобразования в угольной пыли при взрывах

S.B. Romanchenko, V.V. Sobolev, A.A. Trubitsyn. Physical and chemical transformations in coal dust by explosions

\section{І. ПРОМЫШЛЕННАЯ БЕЗОПАСНОСТЬ И ГЕОМЕХАНИКА // INDUSTRIAL SAFETY AND GEOMECHANICS}

20 В.В. Иванов, А.А. Родионов, В.В. Семенцов, Д.Ю. Палеев, С.В. Сороковых. Применение метода электротомографии к определению местоположения нарушений и выбросоопасных зон угольных пластов

V.V. Ivanov, A.A. Rodionov, V.V. Sementsov, D. .Yu. Paleev, S.V. Sorokovih. Electrotomography method application to determining the coal seams' disturbed and outburst zones location

\section{II. ПОЖАРНАЯ И ПРОМЫШЛЕННАЯ БЕЗОПАСНОСТЬ // FIRE AND INDUSTRIAL SAFETY}

23 С.Б. Романченко, М. О. Девликанов. Исследование динамики выхода летучих веществ из угольной пыли методами термогравиметрического анализа

S. B. Romanchenko, M.O.Devlikanov. Volatile substances emission from coal dust dynamics study by methods of thermogravimetric analysis

31 А.В. Угольников. Критериальное уравнение гидровихревой коагуляции взрывоопасных аэрозолей.

A.V. Ugolnikov Criteria equation for hydro-vortex coagulation of explosive aerosols

38 А.И. Фомин, Д.А. Бесперстов, О.В. Рудюк. Обеспечение безопасности граждан в районах проживания угольных предприятий. Шламоотстойники

A.I. Fomin, D.A. Besperstov, O.V. Rudyuk. Ensuring the safety of citizens in the areas of residence of the coal enterprises. Sludge traps

43 А.И. Фомин, Д.А. Бесперстов, В.В. Соболев. Методика прогноза уровня охраны и безопасности работников угольной промышленности на основе прогноза управления производственными рисками.

A.I. Fomin, D.A. Besperstov, V.V.Sobolev. Occupational health and coal industry workers safety level forecasting methods based on the production risk management forecast

II. ТЕХНОЛОГИЧЕСКИЕ ВОПРОСЫ БЕЗОПАСНОСТИ ГОРНЫХ PAБOT // TECHNOLOGICAL QUESTIONS OF MINING WORK SAFETY

49 Р.И. Родин, М.В. Шинкевич. Оценка эффрективности пластовой дегазации на основе статистического анализа дебита

A.I. Rodin, M.V. Shinkevich. Seam degassing efficiency estimation based on degassing boreholes output statistical analysis 
55 П.Б. Герике, А.Г. Никитин. Диагностика планетарных редукторов по параметрам вибрации.

P.B. Gerike, A.G. Nikitin. Diagnostics of planetary gears by vibration parameters

62 А.В. Дягилева, А.В. Каплун. Сравнительный анализ фрормул по нахождению длины шага интервального вариационного ряда при статистической обработке результатов шахтных исследований технологических режимов ведения горных работ

A.V .Diagileva, A.V .Kaplun. Comparative analysis of formulas for finding the length of interval variation series' step in the statistical data processing of the results of mine researches of technological operation of mining modes

67 Ю.А. Масаев, А.И. Копытов, В.Ю. Масаев, М.А. Яковченко. Влияние развития уәледобычи на экологическую обстановку в Кузбассе

Yu.A. Masaev, A.I. Kopytov, V.Yu. Masaev, M.A. Yakovchenko. Influence of coal mining development on environmental conditions in kuzbass

\section{IV. ПРОБЛЕМЫ И СУЖДДЕНИЯ // PROBLEMS AND OPINIONS}

76 с. В. Бычков. Энергия землятресения и законы гидродинамиких

S.V. Bychkov. Earthquake energy and the laws of hydrodynamics

\section{VI. МЕЖДУНАРОДНЫЙ ОПЫТ // PROBLEMS AND OPINIONS}

84 С. В. Бычков. Термоядерный синтез как источник сейсмических явлений?

S.V. Bychkov. Thermonuclear fusion as seismic phenomena source?

\section{TРЕБОВАНИЯ К РЕКЛАМНЫМ МАТЕРИАЛАМ // ADVERTISING MATERIALS REQUIREMENTS}

\section{TPEБОВАНИЯ К СТАТЬЯМ // DEMANDS TO ARTICLES \\ 96 СОДЕРЖАНИЕ // CONTENT}


Подписано в печать 19.12.2018. Тираж 1000 экз. Формат 60х90 1/8.

Выпуск 4-2019, дата выхода в свет 25.12.2019

Объем 10 п. л. Заказ № 42019 г. Цена свободная.

Типография ООО «ИНТ».

650065, Россия, Кемеровская область, г. Кемерово, пр-т Октябрьский, 28 офис 215 Тел. 8 (3842) 657889. 